\title{
The Association of Electronic Health Record Use on Quality of Care for Patients Diagnosed with Type 2 Diabetes
}

\author{
Rini Rachmawaty \\ Makassar, Indonesia \\ BSN, University of Indonesia, 2002 \\ Professional Nurse, University of Indonesia, 2003 \\ MN, University of Technology Sydney, 2008 \\ A Dissertation presented to the Graduate Faculty \\ of the University of Virginia in Candidacy for the Degree of \\ Doctor of Philosophy in the Graduate School of Arts and Sciences \\ Department of Nursing \\ University of Virginia \\ May, 2014
}




\begin{abstract}
Purpose: Diabetes affects 25.6 million adults in the United States. This longitudinal secondary data analysis aimed to determine whether the use of electronic health records (EHRs) produces changes in quality of care (process and intermediate outcomes) for the same adult patients diagnosed with type 2 diabetes over time.

Methods: This study used data from a CDR and EpicCare system that were queried from pre-EHR, one year post-EHR, and two years post-EHR. The sample included patients aged 18-75 years diagnosed with type 2 diabetes who had outpatient visits at the three time points. Quality of diabetes care was assessed using a guideline developed by the National Diabetes Quality Improvement Alliance in 2005. Process measures included frequency of $\mathrm{HbA1c}, \mathrm{BP}$, and lipid profile tests documented for each patient and proportion of patients who had at least one process measure documented at each time point. In addition, intermediate outcome measures included levels of $\mathrm{HbA1c}, \mathrm{BP}$, and lipid profile achieved by each patient and proportion of patients who achieved the recommended levels of $\mathrm{HbA1c}, \mathrm{BP}$, and lipid profile at each time point. Results: Quality of diabetes care for the 1,201 patients differed pre- and post-EHR. In process measure, the frequency of BP control and the proportion of patients who had at least one BP measurement documented increased one year and two years post-EHR. In intermediate outcome measures, the proportion of patients who achieved total cholesterol $<170 \mathrm{mg} / \mathrm{dL}$ improved two years post-EHR. However, patients were less likely to achieve HbA1c $\leq 7 \%$ and SBP $<140 \mathrm{mmHg}$ post-EHR. Moreover, levels of HbA1c, BP, and HDL-C of the same patients increased over time. Age, sex, race, and type of health insurance predicted the changes in $\mathrm{HbA1c}, \mathrm{BP}$, and HDL-C post-EHR.
\end{abstract}


Conclusion: EHR use improves the BP documentation and promotes changes in clinical staff and patient behavior due to better data at the point of care. Further studies to examine the effect of other comprehensive EHR components (e.g., clinical decision support system) on quality of diabetes care are recommended. Suggestions for hospital administrators to consider EHR adoption and to add nursing care elements to their EHRs are also offered by this study. 


\section{TABLE OF CONTENTS}

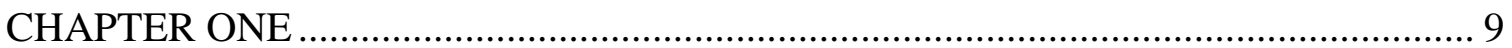

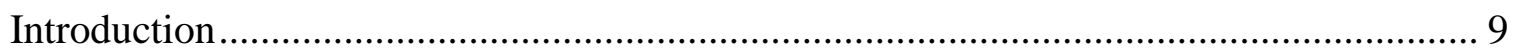

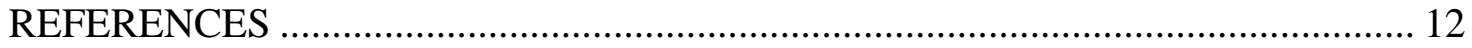

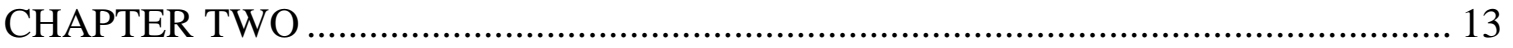

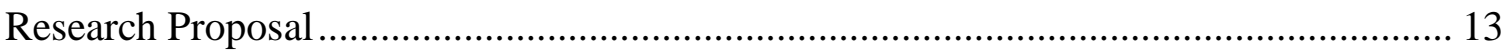

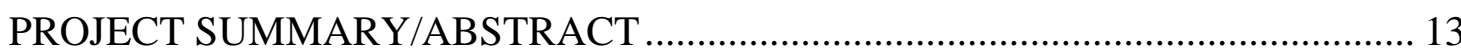

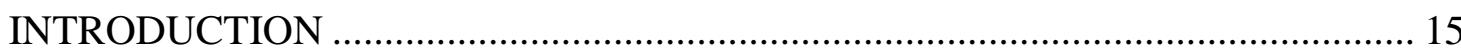

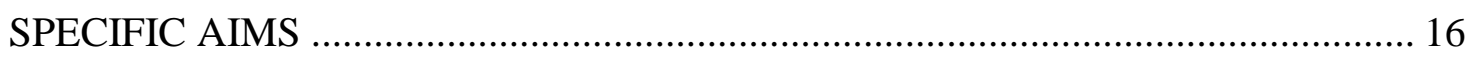

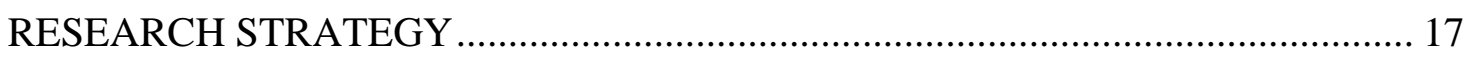

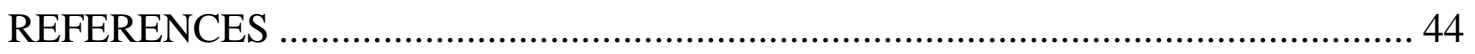

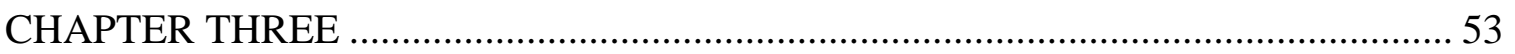

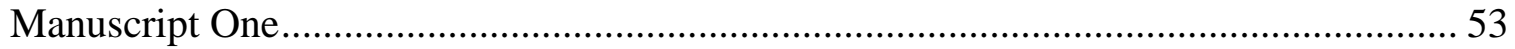

'Nurses' and Other Users' Perceptions of the Effects of Electronic Health Records

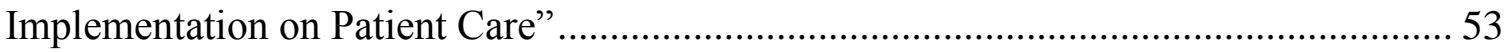

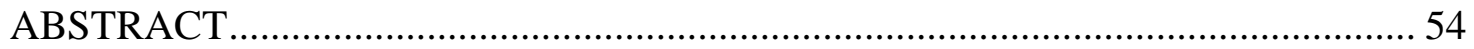

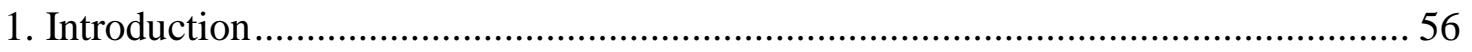

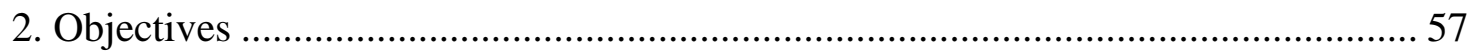

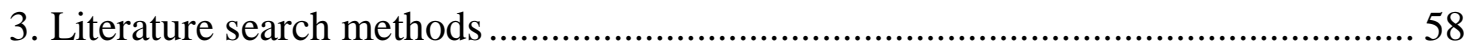

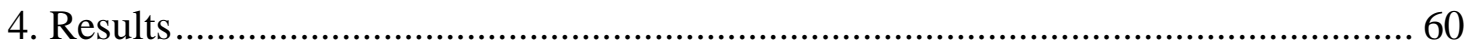

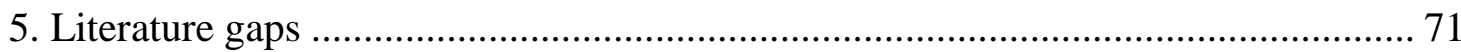

6. Implications for administrative decisions, policy, and future studies...................... 72

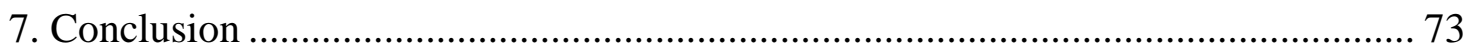

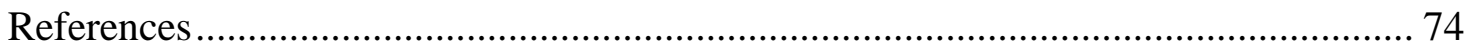

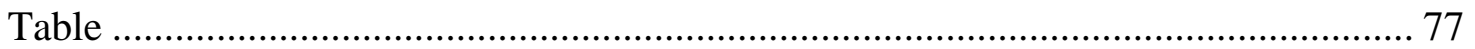

Characteristics of Studies Included in Qualitative Study Review ............................... 77

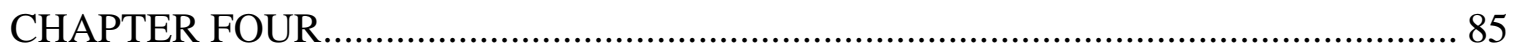

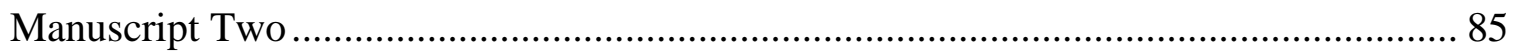

"The Effects of Using Electronic Health Records on the Quality of Diabetes Care: ....... 85

An Integrative Literature Review"............................................................................. 85

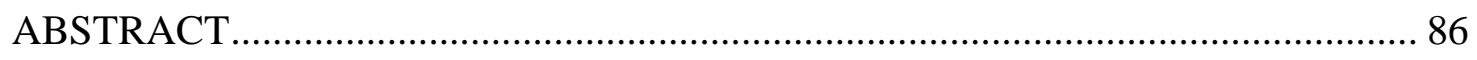

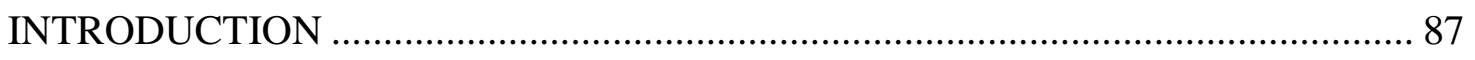

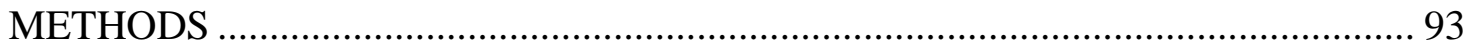




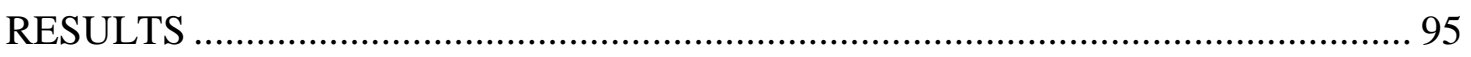

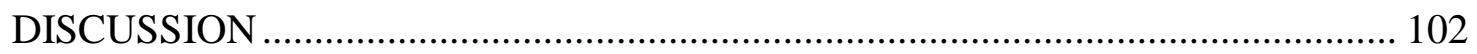

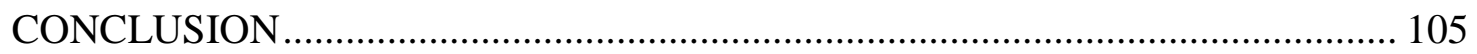

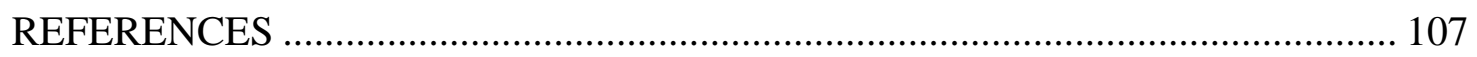

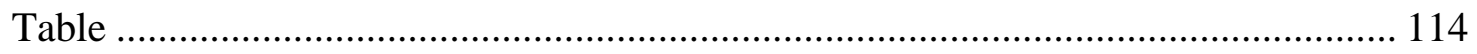

Characteristics of Studies Included in Integrative Literature Review about the Effects of Using Electronic Health Records on the Quality of Diabetes Care........................ 114

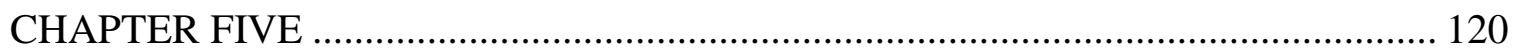

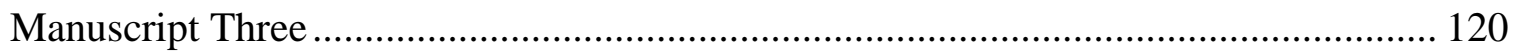

"The Association of Electronic Health Record Use on Quality of Care for Patients Diagnosed with Type 2 Diabetes" ......................................................................... 120

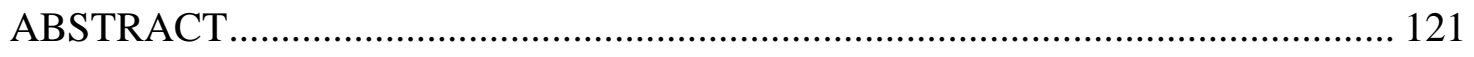

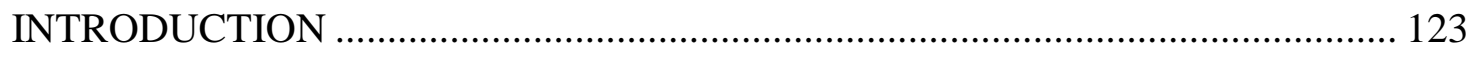

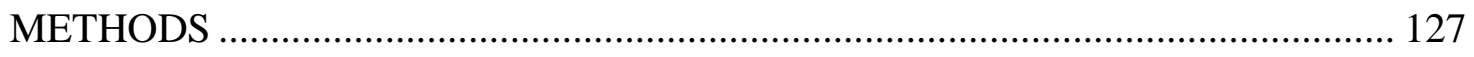

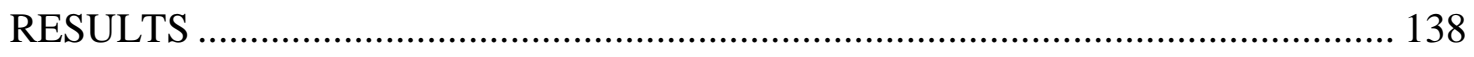

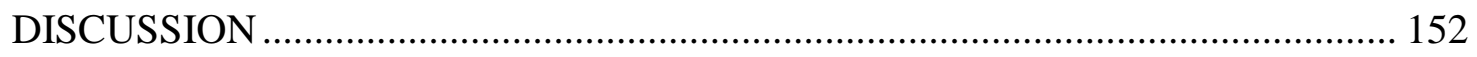

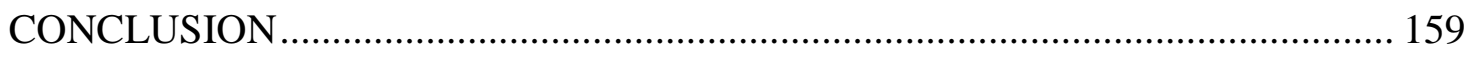

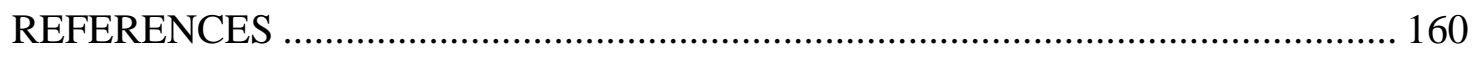

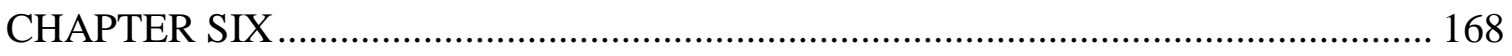

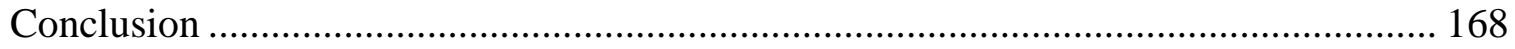

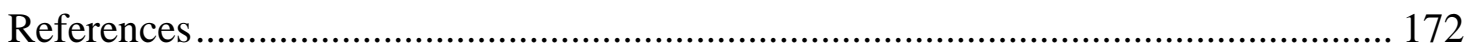

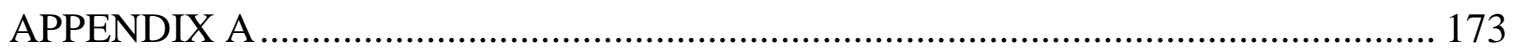

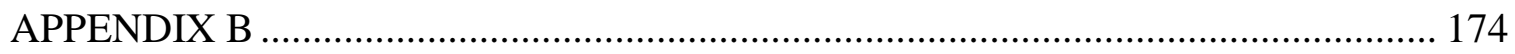

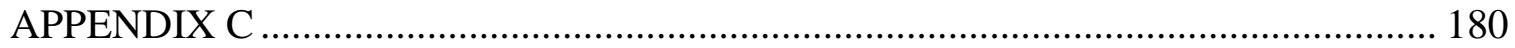

Author Guidelines for International Journal of Nursing Studies .................................... 180

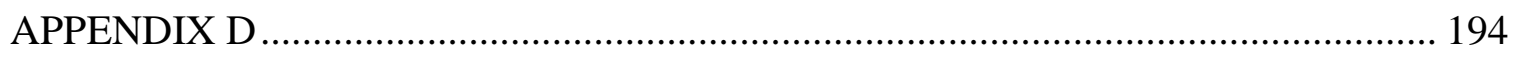

Author Guidelines for Computers, Informatics, Nursing ............................................. 194

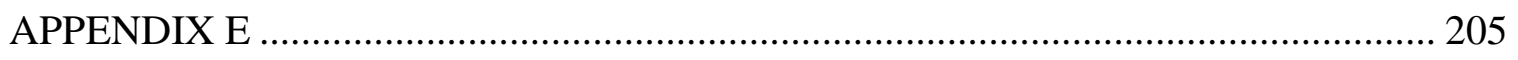

Author Guidelines for Journal of Nursing Care Quality............................................... 205 


\section{FINANCIAL ACKNOWLEDGEMENTS}

Ms. Rachmawaty received a Fulbright Presidential Scholarship in 2010 - 2013 to study for a PhD in nursing at the University of Virginia. In the 2013 - 2014 academic year, she received a Graduate Teaching Assistantship from the School of Nursing, University of Virginia. This financial support was used to complete her doctoral education after the termination of the Fulbright scholarship. 


\section{ACKNOWLEDGEMENTS}

I wish to give special thanks to my advisor, my dissertation chair, and my morale booster, Dr. Marianne Baernholdt, who never left me alone in difficult times. She was always patient in guiding me during the past four years, and always believed in my ability to complete the program and get my $\mathrm{PhD}$ degree. Thanking her is not enough!

Thanks to the dissertation committee, Dr. Susan Huerta, Dr. Guofen Yan, and Dr. Myra Clark, for their suggestions and feedback prior to and during the development of my dissertation proposal and after the dissertation proposal defense. I really appreciate their input which proved to be very valuable in guiding me through my dissertation research.

To Ken and Ron, thanks for providing me with the CDR data. To Dr. Hinton, thanks for helping me with database management. To Dr. Bourguignon and Dr. Anderson, thanks for providing me with references for my statistical analysis during the development of my dissertation proposal. To Dr. Rovnyak, thanks for your clarification of my statistical analysis.

To Dr. Irawan Yusuf and Dr. Ilham Patellongi (Hasanuddin University, Indonesia), Dr. Elly Nurachmah (University of Indonesia), and Dr. Roslyn Sorensen (University of Technology Sydney), thank you for supporting me during my application process for the Fulbright scholarship and the admission to the University of Virginia School of Nursing (UVA SON).

Thanks to Dr. Linda Bullock, our former PhD director, and Dr. Christine Kennedy, our new PhD director at the UVA SON. I was lucky to have them, who encouraged me to complete my study. 
Thanks to Dean Fontaine, Dr. Janie Heath, Dr. Arlene Keeling, Dr. Pam Kulbok, and Mr. Clay Hysell, who provided me with financial support for my fourth year through the Graduate Teaching Assistantships (GTA) program. Without this support, I might have not been able to complete my study.

To all the faculty members at the UVA SON, thanks for the knowledge during my two years of course work, my research practicum, and my work as an international GTA.

To my friends Mollie, Aya, Pei, Iin, Hee Jung, Jennifer, Juliane, Patty, Mahesh, Karen, and Julie, I appreciate your support and friendship that made me strong and able to keep on going.

Finally, I thank God for giving me a wonderful mother, Sundari, who has taken care of my two beautiful, smart, strong children, Alisha and Aurora, in Indonesia since I began studying here in the United States. I thank my husband Marco, who lives in the United Kingdom, but always supports me during my studies. Thanks to my wonderful sister, Anita; my brother-in-law, William; and my brothers, Iim and Ponco, for their support. 


\section{CHAPTER ONE}

\section{Introduction}

Diabetes is a serious chronic disease and if it is not treated and controlled properly, it can cause long-term microvascular and macrovascular complications, including heart disease, stroke, chronic kidney disease, neuropathy, and retinopathy (Centers for Disease Control and Prevention [CDC], 2011). In the United States (US), the number of adults aged 18 years and above diagnosed with diabetes had more than tripled from 5.5 million in 1980 to 20.8 million in 2011, and the majority of them had type 2 diabetes (CDC, 2011). In 2007, diabetes was determined as the seventh leading cause of death in the US based on 71,382 death certificates (CDC, 2011). Furthermore, medical care costs related to US population diagnosed with diabetes are estimated to increase from $\$ 245$ billion in 2012 to almost $\$ 500$ billion in 2020 (American Diabetes Association [ADA], 2013; United Health Group, 2010).

With regard to all consequences and economic costs resulting from unmanaged diabetes, in 2001 the Institute of Medicine (IOM) recommended a variety of strategies to enhance public policy concerning health care quality improvement, including attention to care for chronic diseases (IOM, 2001; Jha et al., 2009; Jha, DesRoches, Kralovec, \& Joshi, 2010). Under the American Recovery and Reinvestment Act of 2009 (ARRA), one strategy to manage patients with chronic diseases is to use electronic health records (EHRs) (Shih, McCullough, Wang, Singer, \& Parsons, 2011; Young \& Potru, 2011).

The purpose of this dissertation was to investigate the association of EHR implementation on quality of care (process and intermediate outcomes) for adult patients diagnosed with type 2 diabetes who visited outpatient services in one health system. This 
dissertation presents a research proposal that investigated the association of EHR use on the quality of care for patients diagnosed with type 2 diabetes and three manuscripts. Two are integrative literature reviews of qualitative and quantitative studies leading to the study, while the third reports the results of the study that examined the association of EHR implementation on quality of care for patients diagnosed with type 2 diabetes over three time points.

The first manuscript presented is 'Nurses' and Other Users' Perceptions of the Effects of Electronic Health Records Implementation on Patient Care”. This manuscript provides an integrative literature review on qualitative research that addresses the following primary research question: How do nurses and other users perceive the effects of EHR implementation on patient care? The review discusses the articles' research questions, theoretical/conceptual frameworks, data collection methods, findings/conclusions, literature gaps, and implications for future studies. The results of this study will help guide future research and administrative and policy decisions. In this dissertation, the findings of this review were used to develop the background and significance of the dissertation research explained in the third manuscript.

The second manuscript, "The Effects of Using Electronic Health Records on Quality of Diabetes Care: An Integrative Literature Review”, presents the results of previous quantitative studies related to the effect of EHR use on quality of diabetes care. The specific questions that guide this integrative literature review are as follows: How is quality of diabetes care measured? What are the effects of EHR use on quality of diabetes care? This integrative literature review reveals significant findings related to EHRs and quality of diabetes care. The results of this review were used to develop the background, 
significance, design, and methods of the dissertation research explained in the third manuscript.

The third manuscript investigates the association of EHR use on the quality of care for patients diagnosed with type 2 diabetes who visited outpatient services in one teaching hospital located in Central Virginia. The manuscript, "The Association of Electronic Health Record Use on Quality of Care for Patients Diagnosed with Type 2 Diabetes", examines patient data that were extracted from the hospital clinical data repository (CDR) and EpicCare system over three time points: pre-EHR, one year postEHR, and two years post-EHR. This manuscript presents results for McNemar's tests, paired sample $t$-tests, and multiple regressions that analyzed changes 1) in the process of diabetes care and 2) in the intermediate outcomes of diabetes care for the same patient diagnosed with type 2 diabetes over time and investigated whether the changes persist after controlling for race, age, sex, and type of health insurance.

The dissertation concludes in Chapter Six with an overview of the most important findings of the two reviews and the results of the third manuscript that examines the association of EHR use on quality of care for patients diagnosed with type 2 diabetes. Recommendations for future studies are also provided in Chapter Six. 


\section{REFERENCES}

American Diabetes Association (ADA). (2013). Economic costs of diabetes in the U.S. in 2012. Diabetes Care, 36(4), 1033-1046. doi: 10.2337/dc12-2625.

Centers for Disease Control and Prevention (CDC). (2011). National diabetes fact sheet: National estimates and general information on diabetes and prediabetes in the United States, 2011. Atlanta, GA: US Department of Health and Human Services, Centers for Disease Control and Prevention.

Institute of Medicine (IOM). (2001). Crossing the quality chasm: A new health system for the 21st century. Washington, D.C.: National Academy Press.

Jha, A. K., DesRoches, C. M., Campbell, E. G., Donelan, K., Rao, S. R., Ferris, T. G., . . Blumenthal, D. (2009). The use of electronic health records in U.S. hospitals. The New England Journal of Medicine, 360(16), 1628-1638.

Jha, A. K., DesRoches, C. M., Kralovec, P. D., \& Joshi, M.S. (2010). A progress report on electronic health records in U.S. hospitals. Health Affairs, 29(10), 1-7.

Shih, S. C., McCullough, C. M., Wang, J. J., Singer, J., \& Parsons, A. S. (2011). Health information systems in small practices: Improving the delivery of clinical preventive services. American Journal of Preventive Medicine, 41(6), 603-609.

United Health Group. (2010). The United States of diabetes: Challenges and opportunities in the decade ahead. Minnesota: United Health Group.

Young, L. A., \& Potru, P. (2011). Diabetes in North Carolina: Descriptive epidemiology and meaningful use of electronic health records. North Carolina Medical Journal, 72(5), 383-386. 


\section{CHAPTER TWO}

\section{Research Proposal}

\section{PROJECT SUMMARY/ABSTRACT}

Diabetes is the foremost cause of microvascular and macrovascular complications among adults in the United States (US). In 2011, 20.8 million adults in the US diagnosed with diabetes. This number has increased by $74.8 \%$ from 11.9 million in 2000. In 2007, diabetes emerged as the seventh leading cause of death. Economic costs of diabetes in the US are projected to rise by $104 \%$ by 2020 . The American Recovery and Reinvestment Act of 2009 recommends use of electronic health records (EHRs) as a solution to manage patients with chronic diseases. Six studies specifically demonstrate that EHR use improved quality of diabetes care. These studies, however, did not examine changes in quality of care within the same patients at several time points. It remains unclear whether EHR implementation achieves better quality of care and outcomes. The long-term goal of this study is to generate knowledge that clarifies whether EHR use improves quality of care for patients diagnosed with type 2 diabetes. The main purpose of this study was to determine whether EHR use produces changes in quality of care over time for the same patients diagnosed with type 2 diabetes, who had visits to outpatient units of one health system. Quality of diabetes care (process and outcome) was assessed using process measures and intermediate outcome measures developed by the National Diabetes Quality Improvement Alliance (NDQIA) in 2005. This longitudinal secondary data analysis used data from a CDR and EpicCare system that were queried at three time points: pre-EHR, one year post-EHR, and two years post-EHR. The specific aims of this study were to investigate longitudinal changes 1) in processes of diabetes care in patients 
diagnosed with type 2 diabetes over time (from pre-EHR to one year post-EHR, and two years post-EHR) and 2) in intermediate outcomes of diabetes care in patients diagnosed with type 2 diabetes over time (from pre-EHR to one year post-EHR, and two years postEHR). When changes were found, the principal investigator (PI) investigated whether the changes persisted after controlling for age, sex, race, and type of health insurance. All patients aged 18-75 years diagnosed with type 2 diabetes who had outpatient visits at the three time points were included. Patients older than 75 years of age were excluded because $\mathrm{HbA1c}$ level increases with age. A total of 1,201 patients were captured at each time point. Descriptive statistics, McNemar's tests, paired sample $t$-tests, and multiple regressions were used for statistical analysis. This study employed a new approach that had not been used in existing literature to determine whether EHR use improves quality of diabetes care in the same patients diagnosed with type 2 diabetes who visited outpatient services at the same health care system. The study results can be used as evidence for hospital administrators when considering adoption of EHRs and can be used as a foundation for eligible professionals, particularly physicians and nurses, to understand which elements of documentation need to be improved in order to meet the EHR meaningful use criteria. 


\section{INTRODUCTION}

The Centers for Disease Control and Prevention (CDC) (2011) reported that in 2010, 25.6 million people aged 20 years or older in the United States (US) had diabetes and $90-95 \%$ of them had type 2 diabetes. The CDC (2013) also reported that the number of hospital discharges with diabetes as the first-listed diagnosis increased from 454,000 in 1988 to 688,000 in 2009 . Furthermore, among US adults, diabetes is the foremost cause of heart disease and stroke, and it also contributes to chronic kidney disease, neuropathy, and retinopathy. Moreover, the economic costs of diabetes in the US are predicted to increase by 104\% by 2020 (American Diabetes Association [ADA], 2013a; United Health Group, 2010). These conditions have led the US to become more innovative and effective in its battle with the growing diabetes epidemic facing its citizens. The American Recovery and Reinvestment Act of 2009 (ARRA) included the recommendation to use electronic health records (EHRs) as one solution to manage patients with chronic diseases, including diabetes (Shih, McCullough, Wang, Singer, \& Parsons, 2011; Young \& Potru, 2011).

Four studies showed that hospitals with EHRs have better patient safety and other quality outcomes compared to those without EHRs (Dahm \& Wadensten, 2008; de Veer \& Francke, 2010; Kelley, Brandon, \& Docherty, 2011; Kutney-Lee \& Kelly, 2011). Six other studies, which were specifically conducted to examine the association between EHR adoption and quality of diabetes care, have also demonstrated that employing EHRs improved quality of diabetes care (Cebul, Love, Jain, \& Hebert, 2011; Friedberg et al., 2009; Herrin et al., 2012; Martirosyan, Arah, Haaijer-Ruskamp, Braspenning, \& Denig, 2010; Perez-Cuevas et al., 2012; Weber, Bloom, Pierdon, \& Wood, 2007). Quality of 
diabetes care was assessed using process and intermediate outcome measures developed by the National Diabetes Quality Improvement Alliance (NDQIA) (2005).

In the US health care system, no studies have been conducted specifically to examine the association of EHR implementation on quality of care for the same patients diagnosed with type 2 diabetes. Moreover, although the widespread adoption and meaningful use of EHRs is a national priority, there is still a gap in the adoption of EHRs in the US. In 2013, 78\% of office-based physicians had adopted a type of EHR system, classified as either basic or comprehensive (Hsiao \& Hing, 2014). Hospitals were categorized as having basic EHRs if a set of 10 EHR clinical functions was present in at least one major hospital unit. Meanwhile, hospitals were classified as having comprehensive EHRs if a set of 24 EHR clinical functions was deployed in all hospital units (see Appendix A Table 1) (Jha et al., 2009).

\section{SPECIFIC AIMS}

The long-term goal of the proposed research, therefore, is to generate knowledge that clarifies whether EHR use is associated with the improvement in quality of care in patients diagnosed with type 2 diabetes. The main purpose of this study was to investigate the association of EHR implementation on quality of care of adult patients diagnosed with type 2 diabetes in a teaching hospital. The quality of care in patients diagnosed with type 2 diabetes was assessed using the 2005 NDQIA process and intermediate outcome measures for diabetes care. Furthermore, the study used data from three time points: pre-EHR, one year post-EHR, and two years post-EHR. Data sources were the hospital's clinical data repository (CDR) and EpicCare system. 
Specific aims of this study were as follows:

1) To investigate longitudinal changes in processes of diabetes care in patients diagnosed with type 2 diabetes over time (from pre-EHR to one year post-EHR and two years post-EHR).

2) To investigate longitudinal changes in intermediate outcomes of diabetes care in patients diagnosed with type 2 diabetes over time (from pre-EHR to one year postEHR and two years post-EHR). If there were changes, the PI investigated whether the changes persisted after controlling for age, sex, race, and type of health insurance.

\section{RESEARCH STRATEGY}

\section{a. SIGNIFICANCE}

\section{Diabetes, Complications, Readmissions, and Health Care Costs}

The CDC (2013) reported that from 1980 to 2011, the number of noninstitutionalized US adults aged $\geq 18$ years with diagnosed diabetes tripled, from 5.5 million to 20.8 million. In terms of sex and race, the percentage of Americans diagnosed with diabetes rose by $156 \%$ (from $2.7 \%$ to $6.9 \%$ ) for men, $103 \%$ (from $2.9 \%$ to $5.9 \%$ ) for women, $127 \%$ (from $2.6 \%$ to $5.9 \%$ ) for whites, and $107 \%$ (from $4.5 \%$ to $9.3 \%$ ) for blacks (CDC, 2013). Diagnosis of diabetes is determined based on one of the following criteria: the level of $\mathrm{HbA} 1 \mathrm{c}$ is $\geq 6.5 \%$, or the fasting plasma glucose level is $\geq 126 \mathrm{mg} / \mathrm{dL}(7.0$ $\mathrm{mmol} / \mathrm{L})$, or the 2-hour plasma glucose level is $\geq 200 \mathrm{mg} / \mathrm{dL}(11.1 \mathrm{mmol} / \mathrm{L})$ during an oral glucose tolerance test, or the random plasma glucose is $\geq 200 \mathrm{mg} / \mathrm{dL}(11.1 \mathrm{mmol} / \mathrm{L})$ for patients with classic symptoms of hyperglycemia or hyperglycemic crisis (ADA, 2012a).

Diabetes is a metabolic disorder caused by many factors. The National Diabetes Information Clearinghouse (NDIC) (2012) classifies diabetes into four clinical classes 
based on the causes: type 1 diabetes, type 2 diabetes, gestational diabetes (GDM), and other specific types of diabetes. Type 1 diabetes is genetic and occurs due to the inability of the pancreas to produce insulin, while type 2 diabetes develops as a result of both genetic and lifestyle factors. GDM is caused by hormonal changes and metabolic demands of pregnancy and is associated with genetic and environmental factors. Other specific types of diabetes are caused by genetic defects in beta-cell function and in insulin action, diseases of the exocrine pancreas, and drug- or chemical-induced (ADA, 2012a). The ADA (2011) reported that type 2 diabetes accounts for $90-95 \%$ of those with diabetes.

According to the CDC (2013), untreated and uncontrolled diabetes can cause several microvascular and macrovascular complications including cardiovascular disease (CVD), stroke, mortality due to hyperglycemic crises, diabetic ketoacidosis (DKA), endstage renal disease related to diabetes mellitus (ESRD-DM), lower extremity disease (e.g., peripheral arterial disease, ulcer/inflammation/infection, or neuropathy), lower extremity amputation, and visual impairment including blindness. The CDC (2013) reported that in 2011, the number of adults aged 35 years and above diagnosed with diabetes as well as heart disease or stroke increased by $80.9 \%$ (from 4.2 million to 7.6 million). Meanwhile the number of deaths from hyperglycemic crises rose from 2,274 in 2004 to 2,417 in 2009. Similarly, the number of hospital discharges from DKA increased by $75 \%$, from about 80,000 discharges in 1988 to about 140,000 in 2009 . Likewise, the number of patients diagnosed with diabetes initiating treatment for ESRD-DM had risen 18 times, from 2,644 in 1980 to 48,374 in 2008. 
Similar trends were also found in the number of hospital discharges of patients diagnosed with diabetes with lower extremity diseases, which doubled from 445,000 in 1988 to 890,000 in 2007 and in the number of hospital discharges for non-traumatic lower extremity amputation with diabetes, which increased by 24\% from 1988 to 2009 . The number of hospital discharges for visual impairment was also reported to have increased by $48 \%$ from 2.7 million in 1997 to 4.0 million in 2009 among adults diagnosed with diabetes aged 18 years or older (CDC, 2013). As diabetes causes many complications, patients diagnosed with diabetes are more likely to have hospital readmissions than patients without diabetes. A 5-year-retrospective cohort analysis conducted by Menzin et al. (2010) found that the most common causes for diabetesrelated hospitalizations were ischemic heart disease (28.1\%), hyperglycemia (15.7\%), electrolyte imbalance (10.7\%), urinary tract infection (9.1\%), and hypoglycemia (8.3\%). They also found that patients with mean $\mathrm{HbAlc} \geq 10 \%$ were more likely to have one or more diabetes-related hospitalizations than those with mean $\mathrm{HbA1c}<7 \%$ (33.9\% versus 19.5\%). Furthermore, during their 5-year study (2002-2006), they found that patients with mean HbA1c $<7 \%$ had lower average hospital costs $(\$ 2,792)$ than those with mean $\mathrm{HbA} 1 \mathrm{c} \geq 10 \%(\$ 6,759)$.

Readmissions were also higher in patients diagnosed with diabetes, especially for those who were Hispanics and non-Hispanic blacks, females, older, and covered by Medicare or Medicaid (Bennett, Probst, Vyavaharkar, \& Glover, 2012). Likewise, readmissions were reported to be higher in those who had more comorbidities, a longer length of stay, a 30-day follow-up physician visit, and living in low-income areas or in a 
county without a hospital (Jiang, Stryer, Friedman, \& Andrews, 2003; United Health Group, 2010).

Bennett et al. (2012) explained that after being discharged, patients diagnosed with diabetes with complex health care needs often sought care in multiple settings (e.g., inpatient and outpatient) and across specialties (e.g., primary care and specialty care, such as ophthalmologist, dietician, etc.). In addition, a study conducted by Maciejewski and Maynard (2004) in the US Veteran Administration facilities found that the overall cost of diabetes was determined by three factors: diabetes prevalence, health care utilization, and the price of services. For instance, in 1998, 126,373 veterans diagnosed with diabetes utilized VA inpatient services and 1,908,505 veterans diagnosed with diabetes utilized VA outpatient services, which led to total direct cost of diabetes-related services of $\$ 1.67$ billion, including $\$ 214.8$ million in outpatient care and $\$ 1.45$ billion in inpatient care (Maciejewski \& Maynard, 2004). Provision of outpatient glycemic control has been found to reduce readmission (Dungan, 2012).

To sum up, diabetes is a chronic disease that has affected more than 20 million Americans aged 18 years or older in 2011 and caused complications that can lead to deaths (i.e., mortality due to hyperglycemic crises). As a result of these conditions, patients diagnosed with diabetes are at high risk of increased hospital readmissions and healthcare costs. Hence, high quality diabetes care is needed to prevent diabetes-related complications that can reduce hospital readmissions as well as healthcare costs. The following section will discuss a set of diabetes quality performance measures that can be used to assess quality of diabetes care delivered by healthcare providers and received by patients diagnosed with diabetes. 


\section{Measuring Quality of Diabetes Care}

Since diabetes is associated with long-term complications, in 1997 the Diabetes Quality Improvement Program (DQIP) with the support of more than 25 key organizations developed a set of quality performance measures to assess quality of diabetes care in a standardized manner (Kerr, 2008; Lee, Cigolle \& Blaum, 2010). In 2005 , the quality performance measurement set for diabetes was updated by the NDQIA with approval given by 13 organizations, including the Agency for Healthcare Research and Quality (AHRQ), the ADA, the American Medical Association (AMA), the CDC, the CMS, and the Joint Commission on Accreditation of Healthcare Organizations (JCAHO) (Fleming et al., 2001, Lee et al., 2010; NDQIA, 2005). The quality performance measures for diabetes care have been adopted and revised by the National Committee for Quality Assurance (NCQA) (2012) and are known as the 2013 Healthcare Effectiveness Data and Information Set (HEDIS) measures. They are used by $90 \%$ of American health plans to measure health provider performance on important dimensions of care and service.

The diabetes quality performance measures consist of two measures: process measures and outcome measures. Process measures are defined as measures that reflect diabetes care guidelines received by the patient in a year, including $\mathrm{HbA1c}, \mathrm{BP}$, and lipid management; screens for urine protein; examination of the eyes and feet; influenza vaccination; and use of aspirin (Lee et al., 2010; NDQIA, 2005).

The outcome measures also comprise two types of measures: intermediate outcome measures and long-term outcome measures. Intermediate outcome measures are defined as measures that aim to achieve specific thresholds of clinical care, such as physiological or biochemical values, and have been shown to affect the desired health 
outcome positively or adversely (Physician Consortium for Performance Improvement [PCPI], 2011). For patients diagnosed with diabetes, the intermediate outcome measures consist of HbA1c level of $\leq 7 \%$, BP level of $<140 / 80 \mathrm{mmHg}$, total cholesterol level of $<170 \mathrm{mg} / \mathrm{dL}$, high density lipoprotein-cholesterol (HDL-C) level of >45 mg/dL, low density lipoprotein-cholesterol (LDL-C) level of $<100 \mathrm{mg} / \mathrm{dL}$, triglycerides level of $<150$ mg/dL; nonsmoking status; and pregnancy counseling (NDQIA, 2005).

Moreover, long-term outcome measures are defined as measures that include complications and mortality, which are not ideal to assess quality of care over the shortterm (Lee et al., 2010). Since the focus of this proposed study was to examine subjectspecific changes over three years (short-term) after receiving diabetes care, long-term outcome measures could not be evaluated in this study.

This proposed study used the 2005 NDQIA Performance Measurement Set for Adult Diabetes because it was developed and approved by 13 US organizations. It is considered to be the most widely applicable and most accurate set of measures for assessing quality of diabetes care (NDQIA, 2005). In terms of process measures for diabetes care, the NDQIA (2005) recommends healthcare providers should measure HbA1c level at least twice per year. The HbA1c test is recommended because HbA1c reflects average glycemia over several months and has a strong predictive value for diabetes complications (ADA, 2013b). Regarding HbA1c level goals, the ADA (2012a, 2013) has set three different goals: HbA1c level $<6.5 \%$, HbA1c level $\leq 7 \%$ and HbA1c level $<8 \%$. The HbA1c level $<6.5 \%$ is suggested for patients with short duration of diabetes, who have a long life expectancy, with no significant cardiovascular disease, and especially if this goal can be achieved without significant hypoglycemia or other adverse 
effects of treatment (ADA, 2012a). Meanwhile, the less-stringent HbA1c goal $(<8 \%)$ is recommended for patients with a history of severe hypoglycemia, limited life expectancy, advanced microvascular or macrovascular complications, extensive co-morbid conditions, and those with longstanding diabetes (ADA, 2012a). Of the three goals, HbA1c level $\leq 7 \%$ is suggested to most patients who have been diagnosed with diabetes to reduce microvascular and macrovascular complications (ADA, 2012a; NDQIA, 2005). Consequently the PI used this goal in the intermediate outcome measures of the proposed study.

Similarly, a patient's BP should be assessed at every routine diabetes visit (NDQIA, 2005). Meanwhile, it is recommended that the lipid profile be measured during the initial assessment and at least once per year (NDQIA, 2005). Likewise, urine protein, mainly urine albumin excretion and serum creatinine, should be checked during the initial assessment and repeated annually (NDQIA, 2005). The presence of microalbuminuria is the earliest laboratory indicator for nephropathy and usually occurs in patients diagnosed with type 2 diabetes (NDQIA, 2005). Thus, early detection and treatment may prevent or slow the progression of diabetic nephropathy (ADA, 2012b).

Furthermore, it is recommended that a dilated eye examination and comprehensive foot examination be undertaken during the initial evaluation and at least once a year (NDQIA, 2005). Concerning influenza immunization, all adult patients diagnosed with diabetes are recommended to receive this immunization once a year (NDQIA, 2005). Receiving aspirin therapy is included in the process measures for diabetes care, but it is recommended only for patients aged 40 years or older, who have CVD (NDQIA, 2005). 
In addition to goals for laboratory results, the ADA (2013b) suggests that lowering the level of total cholesterol, LDL-C, and BP to the recommended values can reduce diabetes complications, such as $\mathrm{CVD}, \mathrm{CHD}$, and stroke. In addition to the intermediate outcome measures, Willi, Bodenmann, Ghali, Faris, and Cornuz (2007) explained that smokers were $44 \%$ more likely to develop type 2 diabetes than nonsmokers. Hence, assessing patients for smoking status and advising them not to smoke are recommended (NDQIA, 2005).

Electronic Health Records and Quality of Care in Patients with Type 2 Diabetes

An EHR is defined as a longitudinal electronic record that contains complete patient health information generated from one or more clinical encounters in any care delivery setting (Health Information Management Systems Society [HIMSS], 2009). The use of EHRs has been regulated in US health policy since 2001, when the Institute of Medicine (IOM) recommended US health systems should use information technology to improve the quality of care provided to hospitalized patients in those systems (Carrington, 2012; Carrington \& Effken, 2011; IOM, 2001; Kelley et al., 2011; Laramee, Bosek, Kasprisin, \& Powers-Phaneuf, 2011; Rantz et al., 2011).

In 2004, a series of major policy initiatives that promoted the adoption of health information technology (HIT) was launched (DesRoches et al., 2010). Finally in 2009, the adoption of HIT was signed into law in the Health Information Technology Economic and Clinical Health (HITECH) Act, enacted as part of ARRA (US Department of Health and Human Services [US DHHS], 2009). The ARRA also ruled that hospitals across the US are expected to become meaningful users of EHRs by the year 2014 (US DHHS, 2009). "Meaningful use" is defined as the use of certified EHRs in a meaningful manner 
as governed by the Centers for Medicare \& Medicaid Services (CMS) Incentive Programs (CDC, 2012). The CMS offers incentive payments to eligible healthcare providers and hospitals in return for becoming meaningful users of EHRs between 2009 and 2014 (Jha, DesRoches, Kralovec, \& Joshi, 2010). In 2015, financial penalties will be applied to hospitals who have not converted to electronic-based records (Kelley et al., 2011). The intense effort of the US government to require the adoption of EHRs nationwide is reasonable because EHR has been linked to reduction in errors, cutting costs, protection of privacy, and saving lives (Young \& Potru, 2011).

The IOM suggests eight core components as part of an EHR: health information and data, results management, order entry management, decision support, electronic communication and connectivity, patient support, administrative process, and reporting and population health management (IOM, 2003). However, a study conducted by DesRoches, Donelan, Buerhaus, and Zhonghe (2008) shows that only five computerized functions are routinely used in inpatient and outpatient settings: health information and data, results management, order entry management, decision support reporting, and population health management.

Of all the aforementioned core components, decision support is the component that has key elements to improve prevention and determine diagnosis. Decision support also has an important role to play in the management of patient disease, such as screening reminders and management of chronic disease, for example diabetes (DesRoches et al., 2008; IOM, 2003; Thakkar \& Davis, 2006). A retrospective study using chart review methods conducted by Shih et al. (2011) found that after EHR with decision support was adopted by 56 out of 82 primary care providers in New York City, six clinical preventive 
service measures of diabetes improved. The six measures were HbA1c screening, BMI, BP control, aspirin therapy, smoking status, and influenza vaccination. Besides improving the quality of diabetes care, the EHR with decision support also significantly reduced intervention costs per adult patient diagnosed with diabetes by $37 \%$, from $\$ 120$ to $\$ 76$ (Gilmer et al., 2012).

Six other studies have also demonstrated that EHR improved the quality of diabetes care and outcomes (Cebul et al., 2011; Friedberg et al., 2009; Herrin et al., 2012; Martirosyan et al., 2010; Perez-Cuevas et al., 2012; Weber et al., 2007). Most of these studies found that compared to patients diagnosed with diabetes at paper-based practices, those who were at EHR-based practices had better quality of diabetes care and outcomes, indicated by improvements in compliance with processes and intermediate outcome measures. Patients diagnosed with diabetes in EHR sites received care that met all process measures for diabetes care, including $\mathrm{HbA1c}, \mathrm{BP}$, and lipid profile measurements, urine protein screening, eye and foot examination, pneumococcal and influenza vaccinations, and aspirin prescription. Likewise, patients diagnosed with diabetes in the EHR-exposed group showed higher achievements (best or recommended) in intermediate outcome measures than those in the non-EHR-exposed group. In the study conducted by Cebul et al. (2011), it emerged that after controlling for covariates, the percentage of patients diagnosed with diabetes met at least four of the five intermediate outcome measures (HbA1c $<8 \%$, BP $<140 / 80 \mathrm{mmHg}$, LDL-C $<100 \mathrm{mg} / \mathrm{dL}$, BMI $<30 \mathrm{~kg} / \mathrm{m}^{2}$, and nonsmoking status) was higher at EHR sites than those at paperbased sites (43.7\% versus 15.7\%). Similarly, Herrin et al. (2012) revealed that the percentage of patients diagnosed with diabetes who achieved three of the five 
intermediate outcome measures (aspirin use, BP control, and smoking status) was greater in the EHR-exposed group than in the non-EHR-exposed group.

Another benefit of EHR implementation on quality of diabetes care was that EHR data can be used to correctly identify the well-managed and under-managed patients diagnosed with type 2 diabetes (Martirosyan et al., 2010). Moreover, EHR can be used to evaluate quality of care for patients diagnosed with type 2 diabetes who were admitted to the hospitals that have just started to use EHRs (Perez-Cuevas et al., 2012). In this latest study, the researchers used a three-stage mixed methods approach. In stage 1, they developed 18 indicators to assess quality of care following the Appropriateness method developed by RAND-University of California, Los Angeles. This method consists of scientific evidence and expert opinion. Then, in Stage 2, researchers evaluated whether the 18 quality of care indicators (QCIs) defined in Stage 1 could be constructed using EHR data, but only 14 QCIs could be created from this stage. Finally, in Stage 3, they evaluated quality of care received by 25,130 patients diagnosed with type 2 diabetes in 2009 using the 14 QCIs (Perez-Cuevas et al., 2012). All of the aforementioned studies have stated the advantages and positive effects of EHR use on improving the quality of diabetes care and outcomes. The following section will discuss the limitations of the studies above.

Despite the aforementioned positive results, a longitudinal observational study conducted in 42 primary care practices in New Jersey and Pennsylvania by Crosson, Ohman-Strickland, Cohen, Clark, and Crabtree (2012) revealed no association between EHR use and quality of diabetes care (measured by the adherence to care guidelines and rates of improvement). Likewise, a retrospective longitudinal study conducted by 
Linmans, Viechtbauer, Koppenaal, Spigt, and Knottnerus (2012) in 10 primary care practices using EHR located in the Netherlands found that no significant changes occurred in average weight and average $\mathrm{HbAlc}$ over time in 2,549 patients diagnosed with diabetes.

From the literature review above, all studies conducted in the US addressed the quality of care for all types of diabetes, including patients diagnosed with diabetes who have other complications. This was considered as one of the limitations of those studies because many elderly people with multiple diseases could not be expected to achieve all diabetes performance measures. For example, patients with extensive co-morbid conditions might not achieve HbA1c level $<7 \%$ within a short period of time (Weber et al., 2007). Furthermore, although two longitudinal studies (Cebul et al., 2011; Herrin et al., 2012) were conducted to compare quality of diabetes care between EHR sites and non-EHR sites, comparing different adult patients with all types of diabetes who visited different primary care practices into this study, has led to inadequate adjustment for patient characteristics. Thus, inferring that EHRs fully account for the observed differences in quality of diabetes care was not warranted (Cebul et al., 2011). Additionally, these longitudinal studies showed only the differences in quality of diabetes care between patients at EHR practices and those at non-EHR practices. However, the researchers did not examine changes in achieving process and intermediate outcome measures within the same subjects at several points over the study period, which would provide more compelling evidence of the EHR benefits (Cebul et al., 2011; Herrin et al., 2012). Whether EHRs have been used or not, it remains unclear if diabetes performance measures that assess quality of diabetes care within subjects will be higher 
(i.e., best or recommended) than between subjects. Therefore, this study is important because it aims to determine whether there are differences or changes in quality of care for the same patients diagnosed with type 2 diabetes who visited outpatient units of one health system over three time points: pre-EHR, one year post-EHR, and two years postEHR.

\section{b. INNOVATION}

This study employed a new approach that has not been used in the existing literature to determine whether using EHR improves quality of diabetes care. Furthermore, the results of this study provided more compelling evidence than existing studies because same adult patients diagnosed with type 2 diabetes who visited outpatient services at the same health system were measured repeatedly to evaluate differences or changes in diabetes quality performance measures before and after EHR implementation. Hence, whether or not using EHRs improves the quality of care in patients diagnosed with type 2 diabetes is clarified. Furthermore, the results can be used as evidence for hospital administrators when they consider adoption of EHRs. Finally, the results can also be used by nurses who constitute a group of eligible professional to help them meet the meaningful use criteria in order to receive incentive payments from Medicaid.

\section{c. APPROACH}

A longitudinal secondary data analysis was used to address the specific aims of this study, that is, to investigate the association of EHR implementation on quality of care in the same patients diagnosed with type 2 diabetes. Data sets used in this analysis were queried from the CDR and EpicCare system. Data of patients diagnosed with diabetes 
were extracted from three time points: pre-EHR, one year post-EHR, and two years postEHR. The conceptual model used in this study is explained in the following section. Conceptual Model for the Proposed Study

The conceptual model used in this study was adapted from the health care quality model developed by Donabedian $(1969,1988)$ and the structural variables from the triangle model developed by Ancker, Kern, Abramson, and Kaushal (2012). These two models theorize how the use of EHRs affects quality of care in patients diagnosed with type 2 diabetes (see Figure 1 below). Donabedian (1988, p. 1745) defined care of high quality as "that kind of care which is expected to maximize an inclusive measure of patient welfare....” According to Donabedian (1988), quality of care can be assessed from three components: structure, process, and outcome.

Structure is described as the components or factors of an organization in which care occurs, including material resources, human resources, and organizational structure (Donabedian, 1988). Meanwhile, process is defined as "what is actually done in giving and receiving care” (Donabedian, 1988, p. 1745). This includes a practitioner's activities in providing care and the individual patient's activities in seeking care. Finally, outcome is described as "the effect of care on the health status of the patient and population" (Donabedian, 1988, p. 1745). Based on the definition above, Donabedian (1988) explained that the three components have a causal and linear relationship. This means good structure improves the likelihood of good process, and good process improves the likelihood of a good outcome (Donabedian, 1988). This relationship is shown in Figure 1 below. 
Figure 1. Conceptual Model for the Association of Electronic Health Record (EHR) Use on Quality of Care in Patients with Type 2 Diabetes

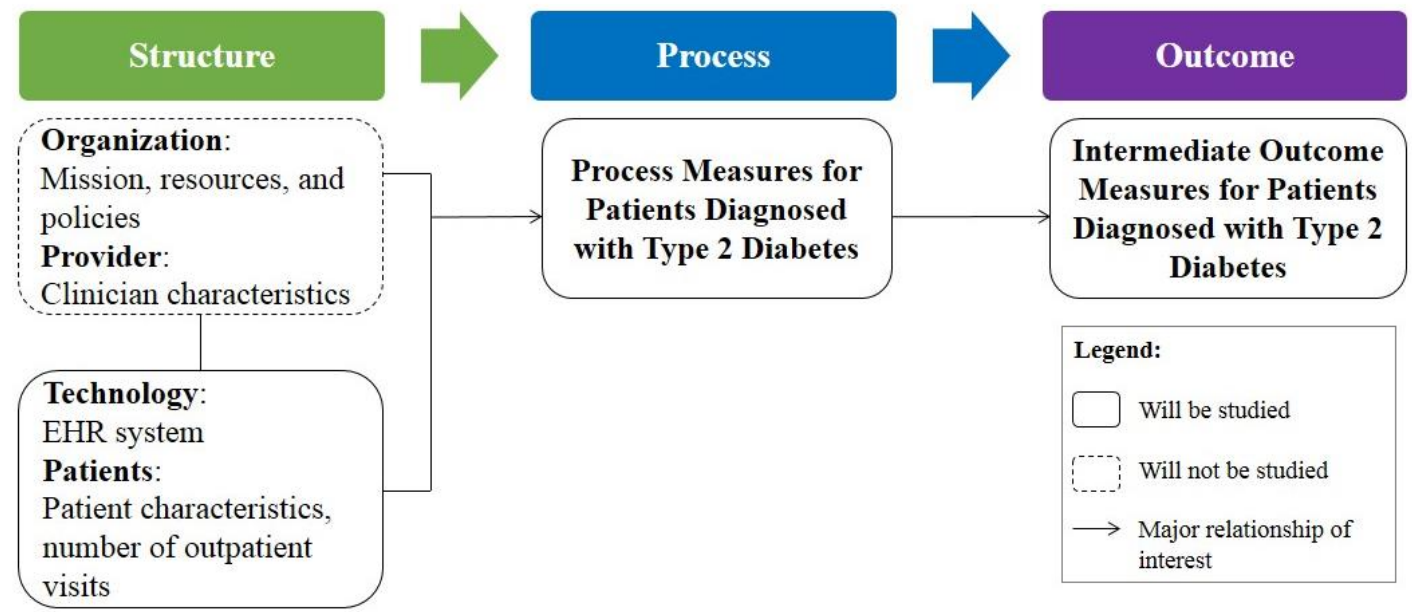

Adapted from: The health care quality model (Donabedian, 1969, 1988) and the triangle model (Ancker, Kern, Abramson, \& Kaushal, 2012)

As is shown in Figure 1, structure has four elements: organization, provider, technology, and patients. These elements were taken from the structural elements of the triangle model (Ancker et al., 2012), which was developed from Donabedian's model, to evaluate the effect of health information technology on healthcare quality and safety. The PI incorporated these elements into Donabedian's model because they explained better the relationship between the use of EHRs and quality of care in patients diagnosed with type 2 diabetes. Based on the triangle model, organization is described as a healthcare organization where the technology is implemented and the place where its mission, resources, and policies directly affect the quality outcomes and usability of the technology to achieve these outcomes. For example, the organization may or may not create usable EHR configuration in patient examination rooms (Ancker et al., 2012). Meanwhile, provider is defined as characteristics of the clinician who uses the system to influence quality and safety outcomes. This includes years in practice, EHR training and experiences, and specialty (Ancker et al., 2012). However, the organization and provider 
were not studied in this research. Only two elements of the structure (i.e., technology and patients) were studied in this research.

Technology is defined as the functional capabilities of the technology that can affect quality and safety, for example, the usability of the user interfaces, or interfaces with other systems (Ancker et al., 2012). For this study, technology was defined as the EHR system that had been adopted in outpatient units, through which comprehensive data of patients diagnosed with type 2 diabetes were retrieved. Patient data before and after EHR use were extracted.

Then, patients are described as individuals who receive care in a healthcare organization. For this study, patients were described as individuals aged 18-75 years diagnosed with type 2 diabetes based on the ICD-9-CM who visited outpatient services in one health system where an EHR system had been implemented. However, according to Ancker et al. (2012), a healthcare organization that treats sicker patients will perform more poorly on patient outcome measures than those who provide care to healthier patients. Thus, methods for risk adjustment are needed to compare achievement on patient outcome measures across healthcare organizations. For this study, changes in intermediate outcome levels over time for patients diagnosed with type 2 diabetes were examined. If there was a change, the PI investigated whether changes persisted after controlling for patient characteristics: age, sex, race, and type of health insurance.

Process was conceptualized as type of care delivered by clinicians and received by patients diagnosed with type 2 diabetes in outpatient units. The quality of the process of care received by patients diagnosed with type 2 diabetes was measured using process 
measures developed by the NDQIA, which has been described in the Significance section.

Finally, outcome was conceptualized as the effect of care on the health status of patients diagnosed with type 2 diabetes during a short-term period. Whether or not the patient diagnosed with type 2 diabetes achieved the best or recommended outcomes was measured using intermediate outcome measures developed by the NDQIA (see the Significance section).

To conclude, if data on patients diagnosed with type 2 diabetes were documented completely in the EHR (structure) and the clinician used EHR in a meaningful manner and followed best practice advisory for diabetes care (embedded in the EHR), all patients should have, first, received high quality care (process), and second, achieved good quality outcomes. The data sources, sample, setting, data management, study measures, and analysis plans used in this study will be discussed in the following sections.

\section{$\underline{\text { Data Sources }}$}

Data sources that were used in this study were from the CDR and EpicCare system. The CDR is a de-identified data warehouse of approximately 1,000,000 patients. It contains more than 15 years' worth of patient information, drawn from its multiple clinics and the Virginia Department of Health. As a unit-level database, it provides important information about patients, for example: patient demographics, inpatient and outpatient visit details, diagnoses, procedures, laboratory results, inpatient medications, outcomes, payers, costs and charges, and reimbursement information (Lyman, 2009). Another data source that was employed in this study was the EpicCare system, an electronic medical record (EMR) system owned by the Epic System Corporation. It has 
been used in 185 health care organizations throughout the US and has been reported as having several advantages including cost savings and patient safety enhancement (Epic Systems Corporation, 2010).

In this study, patient characteristics, HbA1c, and lipid profile pre- and post-EHR were extracted from the CDR. However, as patients' vital signs were available only since October 2010 in the CDR, patient BP values pre-EHR were retrieved from the EpicCare system through chart review, while patient BP values post-EHR were obtained from the CDR (see Table 4).

\section{Sample and Setting}

The study site was a 600-bed university hospital located in Central Virginia. Inclusion criteria for the sample were all patients aged 18-75 years with the principal diagnosis of type 2 diabetes based on the ICD-9-CM (DX 250.xx). Date ranges for this study were from $07 / 01 / 2009$ to $06 / 30 / 2010$ for pre-EHR, from $07 / 01 / 2011$ to $06 / 30 / 2012$ for one year post-EHR, and from 07/1/2012 to 06/30/2013 for two years post-EHR. Data of patient visits were retrieved from outpatient units. For outpatient visits, the date range was based on the date of service. Thus, this study included all patients diagnosed with type 2 diabetes captured at three time points. Compared to two time points (pre-EHR and one year post-EHR), the three time points allowed the PI to see the association of EHR use on quality of care in patients diagnosed with type 2 diabetes over time more accurately.

The exclusion criterion for the sample was patients aged 76 years and above. Patients older than 75 years of age were not included in this study because they were not included in guidelines for diabetes quality performance measures. This is due to HbA1c 
level significantly increasing with age and therefore possibly affecting the variance of the data because an increase may not be related to care (NDQIA, 2005).

\section{$\underline{\text { Data Management }}$}

The researcher retrieved patient data from the CDR for each time point by initially defining the population of interest using the selection criteria above. Afterwards, the data set from pre-EHR was merged with the data set from one year post-EHR by using patient IDs. Last, the new data set from two time points (pre-EHR and one year post-EHR) was merged with the data set from two years post-EHR. This latest data set was used as the final data set for analysis. As shown in Table 2, a total of 1,201 patients diagnosed with type 2 diabetes were captured at three time points. All of these patients had visits to five types of outpatient services: family medicine, internal medicine, cardiology, diabetes services, and endocrinology.

\section{$\underline{\text { Power Analysis }}$}

A power analysis was conducted to estimate the required number of samples. For this study, a total of 206 patients diagnosed with type 2 diabetes were randomly selected from the CDR as a pilot sample. Since the same patients were examined over time, a McNemar's test was used to test for any differences in the proportion of patients receiving $\mathrm{HbA} 1 \mathrm{c}$ tests pre- and one year post-EHR. The calculation of the McNemar's test was run using the nQuery program (Elashoff, 2002).

Table 2 presents results of the McNemar's test. There were 143 (69.4\%) patients who received the HbAlc test pre-EHR and 172 (83.5\%) who received it one year postEHR, which means there was a $14 \%$ difference in proportions, also known as effect size (ES). Furthermore, the McNemar's test demonstrated that of 206 patients, there were 24 
patients who received HbA1c tests only in pre-EHR, but not in one year post-EHR, and 53 patients received $\mathrm{HbA1c}$ tests in one year post-EHR, but not in pre-EHR. These 77 patients of 206 were called as discordant pairs; the proportion of those discordant pairs was $37 \%$ (Elashoff, 2002).

Table 2

McNemar's Test for Power Analysis of Pilot Sample $(n=206)$

\begin{tabular}{|c|c|c|c|c|}
\hline & \multicolumn{3}{|c|}{ One Year Post-EHR } \\
\hline & & Not Received HbA1c Tests & Received HbA1c Tests & Total \\
\hline \multirow{3}{*}{ Pre-EHR } & Not Received HbA1c Tests & 10 & 53 & 63 \\
\hline & Received HbA1c Tests & 24 & 119 & 143 \\
\hline & Total & 34 & 172 & 206 \\
\hline
\end{tabular}

Since the ES of our pilot sample was $14 \%$, we anticipated the ES for process and intermediate outcome measures of this study was around $10 \%-15 \%$. Moreover, as the proportion of discordant pairs from our pilot sample was $37 \%$ or 0.4 , we assumed the proportion of discordant pairs for our study would range from 0.2 to 0.4 . Based on our pilot data, we ran the nQuery program to calculate the required number of samples for our study. For this calculation, we used $10 \%$ ES instead of $15 \%$ ES because a smaller ES requires a greater sample size. Furthermore, we used $90 \%, 85 \%$, and $80 \%$ power with a 2-sided significance level of 0.05 . As shown in Table 3, the required numbers of subjects started from 193 to 412 at $90 \%$, reduced to $167-353$ at $85 \%$, and fell further to $148-309$ at $80 \%$ power. Since the number of subjects was 1,201 , these were much greater than $90 \%$ power.

Table 3

Estimated Required Number of Subjects Assuming a 2-Sided Significance Level of 0.05

\begin{tabular}{|c|c|c|c|c|}
\hline \multirow[b]{2}{*}{$\begin{array}{c}\text { Detectable effect size } \\
\text { (difference in post-pre proportions) }\end{array}$} & \multirow[b]{2}{*}{$\begin{array}{l}\text { Proportion of discordant } \\
\text { pairs }\end{array}$} & \multicolumn{3}{|c|}{ Required number of subjects } \\
\hline & & $\begin{array}{l}80 \% \\
\text { power }\end{array}$ & $\begin{array}{l}85 \% \\
\text { power }\end{array}$ & $\begin{array}{l}90 \% \\
\text { power }\end{array}$ \\
\hline $10 \%$ & 0.2 & 148 & 167 & 193 \\
\hline $10 \%$ & 0.3 & 229 & 261 & 304 \\
\hline $10 \%$ & 0.4 & 309 & 353 & 412 \\
\hline
\end{tabular}




\section{$\underline{\text { Study Measures }}$}

The study variables are defined in Table 4 below and grouped into three concepts:

structure, process, and outcome, according to the study's conceptual model.

Table 4

Concepts, Level of Data, and Source of Data

\begin{tabular}{|c|c|c|c|c|}
\hline Concept & Variable & Operational Definition & $\begin{array}{c}\text { Level of } \\
\text { Measurement/Coding }\end{array}$ & Source \\
\hline $\begin{array}{l}\text { Structure } \\
\text { Electronic } \\
\text { health records } \\
\text { (EHRs) }\end{array}$ & $\begin{array}{l}\text { Time: } \\
\text { 0. Pre-EHR } \\
\text { 1. One year } \\
\text { post-EHR } \\
\text { 2. Two years } \\
\text { post-EHR }\end{array}$ & $\begin{array}{l}\text { 0. A period of time } \\
(07 / 01 / 2009-06 / 30 / 2010) \\
\text { when the EHR system was } \\
\text { not used in the studied } \\
\text { Health System. } \\
\text { 1. One year after all studied } \\
\text { units adopted EHRs } \\
\text { (07/01/2011-06/30/2012). } \\
\text { 2. Two years after all studied } \\
\text { units adopted EHRs } \\
\text { (07/01/2012-06/30/2013). }\end{array}$ & $\begin{array}{l}\text { Categorical } \\
\text { 0. Pre-EHR } \\
\text { 1. One year post- } \\
\text { EHR } \\
\text { 2. Two years post- } \\
\text { EHR }\end{array}$ & CDR \\
\hline \multicolumn{5}{|c|}{ Covariates } \\
\hline \multirow{4}{*}{$\begin{array}{l}\text { Patient } \\
\text { Characteristics }\end{array}$} & Race & $\begin{array}{l}\text { The self-reported of race by } \\
\text { patients diagnosed with type } 2 \\
\text { diabetes }\end{array}$ & $\begin{array}{l}\text { Categorical } \\
\text { 1. White } \\
\text { 2. Black } \\
\text { 3. Other } \\
\end{array}$ & CDR \\
\hline & Age & $\begin{array}{l}\text { The age, in years, of patients } \\
\text { diagnosed with type } 2 \text { diabetes } \\
\text { at the time of service }\end{array}$ & $\begin{array}{l}\text { Categorical (for } \\
\text { sample } \\
\text { characteristics) } \\
\text { 1. } 19-44 \\
2.45-64 \\
\text { 3. } 65-74 \\
\text { Continuous (for } \\
\text { Multiple Regression } \\
\text { analysis) }\end{array}$ & CDR \\
\hline & Sex & $\begin{array}{l}\text { The biological and } \\
\text { physiological characteristics } \\
\text { that define male and female } \\
\text { patients diagnosed with type } 2 \\
\text { diabetes }\end{array}$ & $\begin{array}{l}\text { Categorical } \\
\text { 1. Female } \\
\text { 2. Male }\end{array}$ & CDR \\
\hline & $\begin{array}{l}\text { Type of health } \\
\text { insurance }\end{array}$ & $\begin{array}{l}\text { The type of insurance is based } \\
\text { on the insurance company, or } \\
\text { whoever has paid the most on } \\
\text { the account. }\end{array}$ & $\begin{array}{l}\text { Categorical } \\
\text { 1. Medicare } \\
\text { 2. Medicaid } \\
\text { 3. Uninsured } \\
\text { 4. Private } \\
\text { 5. Other } \\
\end{array}$ & CDR \\
\hline \begin{tabular}{|l|} 
Process: \\
Process \\
Measures for \\
Patients \\
Diagnosed with \\
Type 2 \\
Diabetes \\
\end{tabular} & $\begin{array}{l}\text { HbAlc } \\
\text { Frequency of } \\
\text { HbA1c } \\
\text { measurement }\end{array}$ & $\begin{array}{l}\text { Number of } \mathrm{HbA} 1 \mathrm{c} \\
\text { measurements documented for } \\
\text { each patient diagnosed with } \\
\text { type } 2 \text { diabetes per year. } \\
2005 \text { NDQIA } \\
\text { Recommendation: At least }\end{array}$ & $\begin{array}{l}\text { Continuous } \\
\text { (Aim \#1) } \\
\text { Lab Test Mnemonic } \\
\text { Code: HbA1c }\end{array}$ & CDR \\
\hline
\end{tabular}




\begin{tabular}{|c|c|c|c|c|}
\hline Concept & Variable & Operational Definition & $\begin{array}{c}\text { Level of } \\
\text { Measurement/Coding }\end{array}$ & Source \\
\hline & & $\begin{array}{l}\text { twice } \mathrm{HbA1c} \text { measurements } \\
\text { per year }\end{array}$ & & \\
\hline & $\begin{array}{l}\text { Proportion of } \\
\text { patients who } \\
\text { had at least } \\
\text { HbA1c } \\
\text { measurement } \\
\text { documented }\end{array}$ & $\begin{array}{l}\text { The total number of patients } \\
\text { had one or more HbA1c test(s) } \\
\text { documented per year, divided } \\
\text { by all patients diagnosed with } \\
\text { type } 2 \text { diabetes aged between } \\
18 \text { and } 75 \text { years who had } \\
\text { outpatient visits at three time } \\
\text { points ( } n=1,201) \text {. }\end{array}$ & $\begin{array}{l}\text { Categorical: } \\
\text { 0. The recommended } \\
\text { test was not } \\
\text { documented } \\
\text { 1. The recommended } \\
\text { test was } \\
\text { documented }\end{array}$ & CDR \\
\hline & $\begin{array}{l}B P \\
\text { Frequency of } \\
\text { BP } \\
\text { measurement }\end{array}$ & $\begin{array}{l}\text { Number of BP measurements } \\
\text { documented for each patient } \\
\text { diagnosed with type } 2 \text { diabetes } \\
\text { per year. } 2005 \text { NDQIA } \\
\text { Recommendation: At least one } \\
\text { BP measurement at every } \\
\text { routine diabetes visit. }\end{array}$ & $\begin{array}{l}\text { Continuous } \\
\text { (Aim \#1) } \\
\text { Lab Test Mnemonic } \\
\text { Code: BPS and BPD }\end{array}$ & $\begin{array}{l}\text { CDR \& } \\
\text { EpicCare }\end{array}$ \\
\hline & $\begin{array}{l}\text { Proportion of } \\
\text { patients who } \\
\text { had at least } \\
\text { one BP } \\
\text { measurement } \\
\text { documented }\end{array}$ & $\begin{array}{l}\text { The total number of patients } \\
\text { had one or more BP control } \\
\text { documented per year, divided } \\
\text { by all patients diagnosed with } \\
\text { type } 2 \text { diabetes aged between } \\
18 \text { and } 75 \text { years who had } \\
\text { outpatient visits at three time } \\
\text { points }(n=1,201) .\end{array}$ & $\begin{array}{l}\text { Categorical: } \\
0 . \text { The recommended } \\
\text { test was not } \\
\text { documented } \\
\text { 1. The recommended } \\
\text { test was } \\
\text { documented }\end{array}$ & $\begin{array}{l}\text { CDR \& } \\
\text { EpicCare }\end{array}$ \\
\hline & $\begin{array}{l}\text { Lipid profile } \\
\text { Frequency of } \\
\text { total } \\
\text { cholesterol, } \\
\text { HDL-C, } \\
\text { LDL-C, and } \\
\text { triglycerides } \\
\text { measurements }\end{array}$ & $\begin{array}{l}\text { Number of lipid profile of total } \\
\text { cholesterol, HDL-C, LDL-C, } \\
\text { and triglycerides } \\
\text { measurements documented for } \\
\text { each patient diagnosed with } \\
\text { type } 2 \text { diabetes per year. } \\
2005 \text { NDQIA } \\
\text { Recommendation: At least one } \\
\text { lipid profile measurement per } \\
\text { year }\end{array}$ & $\begin{array}{l}\text { Continuous } \\
(\text { Aim } \# 1) \\
\text { Lab Test Mnemonic } \\
\text { Code: CHOLB, } \\
\text { HDLB, LDLB, and } \\
\text { TRIGB }\end{array}$ & CDR \\
\hline & $\begin{array}{l}\text { Proportion of } \\
\text { patients who } \\
\text { had at least } \\
\text { one lipid } \\
\text { profile } \\
\text { measurement } \\
\text { documented }\end{array}$ & $\begin{array}{l}\text { The total number of patients } \\
\text { had one or more lipid profile } \\
\text { (or all component tests) } \\
\text { documented per year, divided } \\
\text { by all patients diagnosed with } \\
\text { type } 2 \text { diabetes aged between } \\
18 \text { and } 75 \text { years who had } \\
\text { outpatient visits at three time } \\
\text { points }(n=1,201) \text {. }\end{array}$ & $\begin{array}{l}\text { Categorical: } \\
0 . \text { The recommended } \\
\text { test was not } \\
\text { documented } \\
\text { 1. The recommended } \\
\text { test was } \\
\text { documented }\end{array}$ & CDR \\
\hline \multirow{2}{*}{$\begin{array}{l}\text { Outcome: } \\
\text { Intermediate } \\
\text { outcome } \\
\text { Measures for } \\
\text { Patients } \\
\text { Diagnosed with }\end{array}$} & $\begin{array}{l}\text { HbAlc } \\
\quad \text { HbA1c level } \\
(\leq 7 \%)\end{array}$ & $\begin{array}{l}\text { The most recent HbA1c value } \\
(\%) \text { per year. }\end{array}$ & Continuous (Aim \#2) & CDR \\
\hline & $\begin{array}{l}\text { Proportion of } \\
\text { patients } \\
\text { achieving the }\end{array}$ & $\begin{array}{l}\text { The total number of patients } \\
\text { with most recent HbA1c level } \\
\text { less than or equal to } 7 \% \text { for the } \\
\text { year, divided by all patients }\end{array}$ & $\begin{array}{l}\text { Categorical: } \\
0 . \text { Not achieving the } \\
\text { recommended level }\end{array}$ & CDR \\
\hline
\end{tabular}




\begin{tabular}{|c|c|c|c|c|}
\hline Concept & Variable & Operational Definition & $\begin{array}{c}\text { Level of } \\
\text { Measurement/Coding }\end{array}$ & Source \\
\hline \multirow[t]{11}{*}{$\begin{array}{l}\text { Type } 2 \\
\text { Diabetes }\end{array}$} & $\begin{array}{l}\text { recommended } \\
\text { HbA1c level. }\end{array}$ & $\begin{array}{l}\text { diagnosed with type } 2 \text { diabetes } \\
\text { aged between } 18 \text { and } 75 \text { years } \\
\text { who received the HbA1c test. }\end{array}$ & $\begin{array}{l}\text { 1. Achieving the } \\
\text { recommended level }\end{array}$ & \\
\hline & $\begin{array}{l}B P \\
\text { Systolic BP } \\
(<140 \\
\mathrm{mmHg})\end{array}$ & $\begin{array}{l}\text { The most recent systolic BP } \\
\text { value }(\mathrm{mmHg}) \text { per year. }\end{array}$ & Continuous (Aim \#2) & $\begin{array}{l}\text { CDR \& } \\
\text { EpicCare }\end{array}$ \\
\hline & $\begin{array}{l}\text { Proportion of } \\
\text { patients } \\
\text { achieving the } \\
\text { recommended } \\
\text { SBP level. }\end{array}$ & $\begin{array}{l}\text { The total number of patients } \\
\text { with most recent systolic BP } \\
\text { (SBP) level below } 140 \mathrm{mmHg} \\
\text { for the year, divided by all } \\
\text { patients diagnosed with type } 2 \\
\text { diabetes aged between } 18 \text { and } \\
75 \text { years who received the BP } \\
\text { control. }\end{array}$ & $\begin{array}{l}\text { Categorical: } \\
\text { 0. Not achieving the } \\
\text { recommended level } \\
\text { 1. Achieving the } \\
\text { recommended level }\end{array}$ & $\begin{array}{l}\mathrm{CDR} \& \\
\text { EpicCare }\end{array}$ \\
\hline & $\begin{array}{l}\text { Diastolic BP } \\
\text { level }(<80 \\
\mathrm{mmHg})\end{array}$ & $\begin{array}{l}\text { The most recent diastolic BP } \\
\text { value }(\mathrm{mmHg}) \text { per year. }\end{array}$ & Continuous (Aim \#2) & $\begin{array}{l}\text { CDR \& } \\
\text { EpicCare }\end{array}$ \\
\hline & $\begin{array}{l}\text { Proportion of } \\
\text { patients } \\
\text { achieving the } \\
\text { recommended } \\
\text { DBP level. }\end{array}$ & $\begin{array}{l}\text { The total number of patients } \\
\text { with most recent diastolic BP } \\
\text { (DBP) level below } 80 \mathrm{mmHg} \\
\text { for the year, divided by all } \\
\text { patients diagnosed with type } 2 \\
\text { diabetes aged between } 18 \text { and } \\
75 \text { years who received the BP } \\
\text { control. }\end{array}$ & $\begin{array}{l}\text { Categorical: } \\
0 . \text { Not achieving the } \\
\text { recommended level } \\
\text { 1. Achieving the } \\
\text { recommended level }\end{array}$ & $\begin{array}{l}\text { CDR \& } \\
\text { EpicCare }\end{array}$ \\
\hline & $\begin{array}{l}\text { Lipid profile } \\
\text { Total } \\
\text { cholesterol } \\
\text { level }(<170 \\
\mathrm{mg} / \mathrm{dL})\end{array}$ & $\begin{array}{l}\text { The most recent total } \\
\text { cholesterol level value }(\mathrm{mg} / \mathrm{dL}) \\
\text { per year. }\end{array}$ & Continuous (Aim \#2) & CDR \\
\hline & $\begin{array}{l}\text { Proportion of } \\
\text { patients } \\
\text { achieving the } \\
\text { recommended } \\
\text { total } \\
\text { cholesterol } \\
\text { level. }\end{array}$ & $\begin{array}{l}\text { The total number of patients } \\
\text { with most recent total } \\
\text { cholesterol level less than } 170 \\
\text { mg/dL for the year, divided by } \\
\text { all patients diagnosed with } \\
\text { type } 2 \text { diabetes aged between } \\
18 \text { and } 75 \text { years who received } \\
\text { the lipid profile measurement. }\end{array}$ & $\begin{array}{l}\text { Categorical: } \\
0 . \text { Not achieving the } \\
\text { recommended level } \\
\text { 1. Achieving the } \\
\text { recommended level }\end{array}$ & CDR \\
\hline & $\begin{array}{l}\text { HDL-C level } \\
(>45 \mathrm{mg} / \mathrm{dL})\end{array}$ & $\begin{array}{l}\text { The most recent HDL-C level } \\
\text { value }(\mathrm{mg} / \mathrm{dL}) \text { per year. }\end{array}$ & Continuous (Aim \#2) & CDR \\
\hline & $\begin{array}{l}\text { Proportion of } \\
\text { patients } \\
\text { achieving the } \\
\text { recommended } \\
\text { HDL-C level. }\end{array}$ & $\begin{array}{l}\text { The total number of patients } \\
\text { with most recent HDL-C level } \\
\text { greater than } 45 \mathrm{mmHg} \text { for the } \\
\text { year, divided by all patients } \\
\text { diagnosed with type } 2 \text { diabetes } \\
\text { aged between } 18 \text { and } 75 \text { years } \\
\text { who received the lipid profile } \\
\text { measurement. }\end{array}$ & $\begin{array}{l}\text { Categorical: } \\
0 . \text { Not achieving the } \\
\text { recommended level } \\
\text { 1. Achieving the } \\
\text { recommended level }\end{array}$ & CDR \\
\hline & $\begin{array}{l}\text { LDL-C level } \\
(<100 \mathrm{mg} / \mathrm{dL})\end{array}$ & $\begin{array}{l}\text { The most recent LDL-C level } \\
\text { value }(\mathrm{mg} / \mathrm{dL}) \text { per year. }\end{array}$ & Continuous (Aim \#2) & CDR \\
\hline & $\begin{array}{l}\text { Proportion of } \\
\text { patients }\end{array}$ & $\begin{array}{l}\text { The total number of patients } \\
\text { with most recent LDL-C level }\end{array}$ & Categorical: & CDR \\
\hline
\end{tabular}




\begin{tabular}{|c|c|c|c|c|}
\hline Concept & Variable & Operational Definition & $\begin{array}{c}\text { Level of } \\
\text { Measurement/Coding }\end{array}$ & Source \\
\hline & $\begin{array}{l}\text { achieving the } \\
\text { recommended } \\
\text { LDL-C level. }\end{array}$ & $\begin{array}{l}\text { below } 100 \mathrm{mg} / \mathrm{dL} \text { for the year, } \\
\text { divided by all patients } \\
\text { diagnosed with type } 2 \text { diabetes } \\
\text { aged between } 18 \text { and } 75 \text { years } \\
\text { who received the lipid profile } \\
\text { measurement. }\end{array}$ & $\begin{array}{l}\text { 0. Not achieving the } \\
\text { recommended level } \\
\text { 1. Achieving the } \\
\text { recommended level }\end{array}$ & \\
\hline & $\begin{array}{l}\text { Triglycerides } \\
\text { level }(<150 \\
\mathrm{mg} / \mathrm{dL})\end{array}$ & $\begin{array}{l}\text { The most recent triglycerides } \\
\text { level value }(\mathrm{mg} / \mathrm{dL}) \text { per year. }\end{array}$ & Continuous (Aim \#2) & CDR \\
\hline & $\begin{array}{l}\text { Proportion of } \\
\text { patients } \\
\text { achieving the } \\
\text { recommended } \\
\text { triglycerides } \\
\text { level. }\end{array}$ & $\begin{array}{l}\text { The total number of patients } \\
\text { with most recent triglycerides } \\
\text { level less than } 150 \mathrm{mg} / \mathrm{dL} \text { for } \\
\text { the year, divided by all patients } \\
\text { diagnosed with type } 2 \text { diabetes } \\
\text { aged between } 18 \text { and } 75 \text { years } \\
\text { who received the lipid profile } \\
\text { measurement. }\end{array}$ & $\begin{array}{l}\text { Categorical: } \\
\text { 0. Not achieving the } \\
\text { recommended level } \\
\text { 1. Achieving the } \\
\text { recommended level }\end{array}$ & CDR \\
\hline
\end{tabular}

\section{Data Extraction Procedure}

This study used patient data queried from the CDR and EpicCare system, which were identified data. Both data sources - the CDR and EpicCare system - were needed because patients' BP values were not available in the CDR before October 2010. Therefore, patients' BP values pre-EHR were retrieved directly from the EpicCare system (chart review).

Winkelstein (2005) explained that it is essential to have ethics clearance for further use of patient data because ethics is applied in health informatics research in order to address the following issues: privacy, confidentiality, and security of the patient's health information. For this study, authorization was required for access to the CDR website to protect the aforementioned issues (Lyman, 2009). As datasets with real identifiers were accessed, the PI was required to get the CDR account with the authorization of the departmental chair or service center director and to get second level authorization by obtaining approval from the Institutional Review Board for Health 
Sciences Research (IRB-HSR) (Blumenthal et al., 2006; Lyman, 2009). Likewise, using patient data from the EpicCare system requires IRB-HSR approval. These procedures ensure the ethical use of patients' data and are required because the use of secondary data with identifiers is considered a form of human subject research by the Health Insurance Portability and Accountability Act (HIPAA) regulations (US DHHS, 2002).

After obtaining the IRB-HSR approval, the researcher gained access to the EpicCare system and extracted the BP values of 1,201 patients from the first time point (pre-EHR) through the following procedures. First, the investigator obtained the names and medical record numbers (MRNs) for the 1,201 patients from the CDR. Then, the patients were identified in the EpicCare system (ambulatory units), and each patient's chart was reviewed. The chart review process was performed by using the following filters: date range (07/01/2009 - 06/30/2010), department specialty, and attachment type. The date range filter was activated because it automatically populated the patient's visits pre-EHR. Only BP values from the patients who visited the five outpatient services were recorded manually into the investigator's file. When the patients did not have BP values in their charts, the investigator documented only the name of the primary care services and wrote "no BP values" next to those patients' ID numbers. These ID numbers were generated from the CDR to protect patient's confidentiality.

Afterwards, all patient data from chart review (pre-EHR) were saved in the MS Excel program with an encrypted password. In order to merge all patient data $(\mathrm{HbA} 1 \mathrm{c}$, BP, and lipid profile) from three time points, the researcher exported all patient data from MS Excel program to the SPSS program. All statistical data analyses were performed 
using the SPSS program as described in the Analysis Plan section below. Finally, all patient data were destroyed at the completion of this study.

$\underline{\text { Analysis Plan }}$

Crosstabs and chi-square tests were performed to check missing patterns for all dependent variables by covariates, i.e., age, sex, race, and type of health insurance (Meyers, Gamst, \& Guarino, 2013; Munro, 2005). Prior to the analyses described below, all assumptions were checked including normality and diagnostic testing for collinearity.

Descriptive statistics including means $(M)$, standard deviations $(S D)$, and frequencies were calculated to describe the sample and report the frequency of process measures and intermediate outcome levels at three time points (Meyers et al., 2013; Munro, 2005). McNemar's tests were used to examine differences in the proportion of patients who had at least one process measure documented and the proportion of patients achieving the recommended intermediate outcome levels between two time points (preEHR vs. one year post-EHR, and pre-EHR vs. two years post-EHR). The McNemar's test was used because in this study the same subjects were measured twice (pre-EHR vs. one year post-EHR and pre-EHR vs. two years post-EHR) by using proportion. Paired sample $t$-tests were used to examine differences in frequency of process measures documented and in intermediate outcome levels between two time points (pre-EHR vs. one year postEHR, and pre-EHR vs. two years post-EHR). The paired sample $t$-test was used because in this study the same subjects were measured two times (pre-EHR vs. one year postEHR and pre-EHR vs. two years post-EHR) by using means (Meyers et al., 2013; Munro, 2005; Polit \& Beck, 2012). 
Multiple regressions were used to examine the effect of patient characteristics on intermediate outcome levels at one year, and two years post-EHR. ${ }^{49}$ In the multiple regressions, after controlling for each pre-EHR intermediate outcome level, patient characteristics (age, race, sex, and type of health insurance) were used to predict first HbA1c, BP, lipid profile at one year and then at two years post-EHR. Thus, in total 14 multiple regression analyses were conducted. Data were analyzed using SPSS (PASW Statistics version 18) and the level of significance was set at 0.05 , two-tailed (Kinnear \& Gray, 2010; Munro, 2005).

\section{$\underline{\text { Study Limitation }}$}

According to Clarke and Cosette (2000), one major methodological issue in secondary analyses is sample biases due to missing data. They explain that the sample selection criteria (inclusion/exclusion criteria) may limit the generalizability of the study results. As this study's sample consists only of patients diagnosed with type 2 diabetes and who visited outpatient units where EHRs have been implemented, the results may be, first, generalized only to a population with the same characteristics and, second, applied to a health system that is similar to the study setting (Polit \& Beck, 2012). 


\section{REFERENCES}

American Diabetes Association (ADA). (2011). Diagnosis and classification of diabetes mellitus. Diabetes Care, 34(1), 562-569.

American Diabetes Association (ADA). (2012a). Standards of medical care in diabetes 2012. Diabetes Care, 35(1), S11-S63.

American Diabetes Association (ADA). (2012b). Type 2. Virginia: American Diabetes Association. Retrieved from: http://www.diabetes.org/diabetes-basics/type-2/

American Diabetes Association (ADA). (2013a). Economic Costs of Diabetes in the U.S. in 2012. Diabetes Care, 36(4), 1033-1046. doi: 10.2337/dc12-2625.

American Diabetes Association (ADA). (2013b). Standards of medical care in diabetes 2013. Diabetes Care, 36(1), S11-S66.

Ancker, J. S., Kern, L. M., Abramson, E., \& Kaushal, R. (2012). The triangle model for evaluating the effect of health information technology on healthcare quality and safety. JAMIA: Journal of the American Medical Informatics Association, 19(1), 61-65.

Bennett, K. J., Probst, J. C., Vyavaharkar, M., \& Glover, S. H. (2012). Lower rehospitalization rates among rural Medicare beneficiaries with diabetes. The Journal of Rural Health, 28, 227-234.

Blumenthal, D., DesRoches, C., Donelan, K., Ferris, T., Jha, A., Kaushal, R., . . Shield, A. (2006). Health information technology in the United States: The information base for progress. Washington, DC: Robert Wood Johnson Foundation.

Carrington, J. M. (2012). The usefulness of nursing languages to communicate a clinical event. CIN: Computers, Informatics, Nursing, 30(2), 82-88. 
Carrington, J. M. \& Effken, J. A. (2011). Strengths and limitations of the electronic health record for documenting clinical events. CIN: Computers, Informatics, Nursing, 29(6), 360-367.

Cebul, R. D., Love, T. E., Jain, A. K., \& Hebert, C. J. (2011). Electronic health records and quality of diabetes care. The New England Journal of Medicine, 365(9), 825833.

Centers for Disease Control and Prevention (CDC). (2011). National diabetes fact sheet: National estimates and general information on diabetes and prediabetes in the United States, 2011. Atlanta, GA: US Department of Health and Human Services, Centers for Disease Control and Prevention.

Centers for Disease Control and Prevention (CDC). (2012). Meaningful use. Atlanta, GA: US Department of Health and Human Services, Centers for Disease Control and Prevention. Retrieved from: http://www.cdc.gov/ehrmeaningfuluse/introduction.html

Centers for Disease Control and Prevention (CDC). (2013). Diabetes Public Health Resource. Atlanta, GA: US Department of Health and Human Services, Centers for Disease Control and Prevention. Retrieved from: http://www.cdc.gov/diabetes/statistics/prevalence_national.htm

Clarke, S. P., \& Cossette, S. (2000). Secondary analysis: Theoretical, methodological, and practical considerations. Canadian Journal of Nursing Research, 32(3), 109-29.

Crosson, J. C., Ohman-Strickland, P. A., Cohen, D. J., Clark, E. C., \& Crabtree, B. F. (2012). Typical electronic health record use in primary care practices and the 
quality of diabetes care. Annals of Family Medicine, 10(3), 221-227. doi:10.1370/afm.1370

Dahm, M. F., \& Wadensten, B. (2008). Nurses' experiences of and opinions about using standardised care plans in electronic health records - a questionnaire study. Journal of Clinical Nursing, 17, 2137-2145.

DesRoches, C. M., Campbell, E. G., Vogeli, C., Zheng, J., Rao, S. R., Shields, A. E., . . Jha, A.K. (2010). Electronic health records' limited successes suggest more targeted uses. Health Affairs, 29(4), 639-646.

DesRoches, C., Donelan, K., Buerhaus, P., \& Zhonghe, L. (2008). Registered nurses' use of electronic health records: Findings from a national survey. Medscape Journal of Medicine, 10(7), 164.

de Veer, A. J. E., \& Francke, A. L. (2010). Attitudes of nursing staff towards electronic patient records: A questionnaire survey. International Journal of Nursing Studies, $47,846-854$.

Donabedian, A. (1969). Part 2-Some issues in evaluating the quality of nursing care. American Journal of Public Health, 59(10), 1833-1836.

Donabedian, A. (1988). Quality of care: How can it be assessed? Journal of American Medical Association, 260(12), 1743-1748.

Dungan, K. M. (2012). The effect of diabetes on hospital readmissions. Journal of Diabetes Science and Technology, 6(5), 1045-1052.

Elashoff, J. D. (2002). nQuery Advisor Version 5.0 User's Guide. Los Angeles, CA: Microsoft Corporation. 
Epic Systems Corporation. (2010). Epiccare inpatient. Wisconsin: Epic Systems Corporation.

Fleming, B. B., Greenfield, S., Engelgau, M. M., Pogach, L. M., Clauser, S. B., \& Parrott, M. A. (2001). The Diabetes Quality Improvement Project: Moving science into health policy to gain an edge on the diabetes epidemic, Diabetes Care, 24(10), $1815-1820$.

Friedberg, M. W., Coltin, K. L., Safran, D. G., Dresser, M., Zaslavsky, A. M., \& Schneider, E. C. (2009). Associations between structural capabilities of primary care practices and performance on selected quality measures. Annals of Internal Medicine, 151(7), 456-463.

Gilmer, T. P., O'Connor, P. J., Sperl-Hillen, J. M., Rush, W. A., Johnson, P. E., Amundson, G. H., . . Ekstrom, H. L. (2012). Cost-effectiveness of an electronic medical record based clinical decision support system. Health Services Research, 47(6), 2137-2158. doi:10.1111/j.1475-6773.2012.01427.x.

Health Information Management Systems Society (HIMSS). (2009). Electronic health record. Chicago, IL: The Health Information Management Systems Society. Herrin, J., da Graca, B., Nicewander, D., Fullerton, C., Aponte, P., Stanek, G., . . . Ballard, D. J. (2012). The effectiveness of implementing an electronic health record on diabetes care and outcomes. Health Services Research, 47(4), 1522-1540. doi:10.1111/j.1475-6773.2011.01370.x

Hsiao C-J., \& Hing E. (2014). Use and characteristics of electronic health record systems among office-based physician practices: United States, 2001-2013. NCHS data brief, no 143. Hyattsville, MD: National Center for Health Statistics. 
Institute of Medicine (IOM). (2001). Crossing the quality chasm: A new health system for the 21st century. Washington, D.C.: National Academy Press.

Institute of Medicine (IOM). (2003). Key capabilities of an electronic health record system. Washington, D.C.: Institute of Medicine.

Jha, A. K., DesRoches, C. M., Campbell, E. G., Donelan, K., Rao, S. R., Ferris, T. G., . . Blumenthal, D. (2009). The use of electronic health records in U.S. hospitals. The New England Journal of Medicine, 360(16), 1628-1638.

Jha, A. K., DesRoches, C. M., Kralovec, P. D., \& Joshi, M.S. (2010). A progress report on electronic health records in U.S. hospitals. Health Affairs, 29(10), 1-7.

Jiang, H. J., Stryer, D., Friedman, B., \& Andrews, R. (2003). Multiple hospitalizations for patients with diabetes. Diabetes Care, 26(5), 1421-1426.

Kelley, T. F., Brandon, D. H., \& Docherty, S. L. (2011). Electronic nursing documentation as a strategy to improve quality of patient care. Journal of Nursing Scholarship, 43(2), 154-162.

Kerr, E. A. (2008). Assessing Quality of Care for Diabetes. Conference Final Report. (AHRQ Grant No. R13 HS01628). AHRQ Publication No. 08-0037-EF. Rockville, MD; Agency for Healthcare Research and Quality.

Kinnear, P. R., \& Gray, C. (2010). PASW Statistics 17 Made Simple. New York, USA: Psychology Press.

Kutney-Lee, A., \& Kelly, D. (2011). The effect of hospital electronic health record adoption on nurse-assessed quality of care and patient safety. The Journal of Nursing Administration, 41(11), 466-472. doi:10.1097/NNA.0b013e3182346e4b 
Laramee, A. S., Bosek, M., Kasprisin, C. A., \& Powers-Phaneuf, T. (2011). Learning from within to ensure a successful implementation of an electronic health record. CIN: Computers, Informatics, Nursing, 29(8), 468-477.

Lee, P. G., Cigolle, C. T., \& Blaum, C. S. (2010). Quality improvement in the diagnosis and management of Diabetes Mellitus in older adults. Clinical Geriatrics, 18(5), $38-44$.

Linmans, J. J., Viechtbauer, W., Koppenaal, T., Spigt, M., \& Knottnerus, J. A. (2012). Using electronic medical records analysis to investigate the effectiveness of lifestyle programs in real-world primary care is challenging: A case study in diabetes mellitus. Journal of Clinical Epidemiology, 65(7), 785-792.

Lyman, J. (2009). The clinical data repository. Charlottesville: University of Virginia School of Medicine.

Maciejewski, M. L. \& Maynard, C. (2004). Diabetes-related utilization and costs for inpatient and outpatient services in the Veterans administration. Diabetes Care, 27(S2), B69-B73.

Martirosyan, L., Arah, O. A., Haaijer-Ruskamp, F. M., Braspenning, J., \& Denig, P. (2010). Methods to identify the target population: Implications for prescribing quality indicators. BMC Health Services Research, 10, 137-144.

Menzin, J., Korn, J. R., Cohen, J., Lobo, F., Zhang, B., Friedman, M., \& Neumann, P. J. (2010). Relationship between glycemic control and diabetes-related hospital costs in patients with type 1 or type 2 diabetes mellitus. Journal of Managed Care Pharmacy, 16(4), 264-275. 
Meyers, L.S., Gamst, G. C., \& Guarino, A. J. (2013). Applied multivariate research: Design and interpretation (2nd ed.). California, USA: SAGE Publications, Inc.

Munro, B. H. (2005). Statistical methods for health care research $\left(5^{\text {th }}\right.$ ed.). Philadelphia: Lippincott.

National Committee for Quality Assurance (NCQA). (2012). The healthcare effectiveness data and information set (HEDIS) 2013 Measures. Washington, DC: NCQA. Retrieved from: http://www.ncqa.org/Portals/0/HEDISQM/HEDIS2013/List_of_HEDIS_2013_Mea sures_7.2.12.pdf

National Diabetes Information Clearinghouse (NDIC). (2012). Diabetes overview. Bethesda, MD: The National Institute of Diabetes and Digestive and Kidney Diseases (NIDDK). Retrieved from: http://diabetes.niddk.nih.gov/dm/pubs/overview/

National Diabetes Quality Improvement Alliance (NDQIA). (2005). Performance measurement set for adult diabetes. United States: National Diabetes Quality Improvement Alliance. Retrieved from: http://wwwnehc.med.navy.mil/bumed/diabetes/document\%20folders/diabetes/cpg/dqia.msrs.pd $\mathrm{f}$

Perez-Cuevas, R., Doubova, S. V., Suarez-Ortega, M., Law, M., Pande, A., Jorge Escobedo, J., . . W Wagner, A. K. (2012). Evaluating quality of care for patients with type 2 diabetes using electronic health record information in Mexico. BMC Medical Informatics and Decision Making, 12(1), 50-67. 
Physician Consortium for Performance Improvement. (2011). Measures development, methodology, and oversight advisory committee: Recommendations to PCPI work groups on outcome measures. Chicago: American Medical Association.

Polit, D. F., \& Beck, C. T. (2012). Nursing research: Generating and assessing evidence for nursing practice ( $9^{\text {th }}$ ed.). Philadelphia, PA: Wolters Kluwer Health/Lippincott Williams \& Wilkins.

Rantz, M. J., Alexander, F. G., Galambos, C., Flesner, M. K., Vogelsmeier, A., Hicks, L., . . Greenwald, L. (2011). The use of bedside electronic medical record to improve quality of care in nursing facilities: A qualitative analysis. CIN: Computers, Informatics, Nursing, 30(1), TC3-TC10.

Shah, M., Norwood, C. A., Farias, S., Ibrahim, S., Chong, P. H., \& Fogelfeld, L. (2012). Diabetes transitional care from inpatient to outpatient setting: Pharmacist discharge counseling. Journal of Pharmacy Practice, 26(2), 120-124.

Shih, S. C., McCullough, C. M., Wang, J. J., Singer, J., \& Parsons, A. S. (2011). Health information systems in small practices: Improving the delivery of clinical preventive services. American Journal of Preventive Medicine, 41(6), 603-609.

Thakkar, M., \& Davis, D. C. (2006). Risks, barriers, and benefits of EHR systems: A comparative study based on size of hospital. Perspectives in Health Information Management/AHIMA, American Health Information Management Association, $3(5), 1-19$.

United Health Group. (2010). The United States of diabetes: Challenges and opportunities in the decade ahead. Minnesota: United Health Group. 
US Department of Health and Human Services (US DHHS). (2002). Health Information Privacy. Washington D.C.: US DHHS. Retrieved from: http://www.hhs.gov/ocr/privacy/hipaa/administrative/privacyrule/index.html US Department of Health and Human Services (US DHHS). (2009). HITECH act enforcement interim final rule. Washington D.C.: US DHHS.

van Walraven, C., Mamdani, M., Fang, J., \& Austin, P. C. (2004). Continuity of care and patient outcomes after hospital discharge. Journal of General Internal Medicine, 19, 624-631.

Weber, V., Bloom, F., Pierdon, S., \& Wood, C. (2007). Employing the electronic health record to improve diabetes care: A multifaceted intervention in an integrated delivery system. Journal of General Internal Medicine, 23(4), 379-382.

Willi, C., Bodenmann, P., Ghali, W.A., Faris, P. D., \& Cornuz, J. (2007). Active smoking and the risk of type 2 diabetes: A systematic review and meta-analysis. Journal of American Medical Association, 298(22), 2654-2664.

Winkelstein, P. S. (2005). Ethical and social challenges of electronic health information. Medical Informatics, 8, 139-159.

Young, L. A., \& Potru, P. (2011). Diabetes in North Carolina: Descriptive epidemiology and meaningful use of electronic health records. North Carolina Medical Journal, 72(5), 383-386. 


\section{CHAPTER THREE}

\section{Manuscript One}

\section{“Nurses' and Other Users' Perceptions of the Effects of Electronic Health Records Implementation on Patient Care"}

(To be submitted to the International Journal of Nursing Studies)

Author names and credentials: Rini Rachmawaty, MN, RN (Indonesia); Marianne

Baernholdt, PhD, MPH, RN; Susan Huerta, PhD, RN; Myra Clark, PhD, RN, FNP-C.

Author affiliations: School of Nursing, University of Virginia, Charlottesville and Faculty of Medicine, Hasanuddin University, Makassar, Indonesia (Ms. Rachmawaty); School of Nursing and Department of Public Health Sciences, University of Virginia, Charlottesville (Dr. Baernholdt); Froedtert hospital (Dr. Huerta); and School of Nursing, University of Virginia, Charlottesville (Dr. Clark).

Corresponding author: Rini Rachmawaty, MN, RN (Indonesia), School of Nursing, University of Virginia, McLeod Hall, Room \#5031 (Doctoral Lounge), 202 Jeanette Lancaster Way, Charlottesville, VA 22903 (rr7bz@virginia.edu). 


\begin{abstract}
Objectives: The purpose of this review is to examine and synthesize how nurses and other users perceive the effect of electronic health record (EHR) implementation on patient care.

Design and data sources: The integrative review method was used to conduct a review of current qualitative studies published between 2007 and 2014 utilizing CINAHL, EBSCO Host, MEDLINE, OVID, PubMed, and ScienceDirect. Fourteen studies were identified that met the inclusion criteria for review and investigated the nurses' and other users' perceptions about the effects of EHR implementation on patient care.

Results: Studies were synthesized into themes. Nurses and other users had more positive than negative perceptions of the effects of EHR use on patient care. Positive perceptions included EHRs' clinical benefits such as facilitated clinical decision-making, enhanced coordination and communication, usability and enhanced clinical information documentation, and improved quality of patient care. Negative perceptions included decreased time at the bedside for direct patient care and difficulties in getting a quick overview of the patient's condition because nurses need to search through EHRs' many different sections.

Conclusion: The findings of this review suggest that hospital administrators and policy makers who are interested in adopting the EHR system should understand what benefits to expect from employing EHRs and how best to implement the system in order to improve the quality and efficiency of patient care. The results of this review, especially the negative ones, will help future adopters of EHRs to anticipate and resolve difficulties prior to implementing EHRs. Ultimately, future researchers, particularly those
\end{abstract}


researchers interested in implementation research, can use the findings of this review to develop instruments and surveys related to EHR use and quality of patient care.

Keywords: effect of electronic health records, electronic health records, electronic medical records, healthcare providers' perceptions, nurses' perceptions, patient care, quality of care, qualitative research 


\section{Introduction}

Since 2001, the use of electronic health records (EHRs) to improve quality of care for patients admitted to the United States (US) health care system has been recommended by the Institute of Medicine (IOM) (Carrington, 2012; Carrington \& Effken, 2011; Kelley, Brandon, \& Docherty, 2011). The adoption of EHRs is also recommended for use in US nursing homes because it has been found that EHRs improve patient care effectively and efficiently in that setting, too (Rantz et al., 2006).

During the George W. Bush administration, in 2004 a series of major policy initiatives was launched that aimed to speed up the adoption of health information technology (HIT) (DesRoches et al., 2011). On February 17, 2009, the adoption of HIT was signed into law as the Health Information Technology Economic and Clinical Health (HITECH) Act, which served as part of the American Recovery and Reinvestment Act (ARRA) of 2009 (DesRoches et al., 2010; The US Department of Health and Human Services (US DHHS), 2009). The ARRA of 2009 also ruled that hospitals across the US are expected to become meaningful users of EHRs by 2014, and financial penalties will be applied to those hospitals that have not converted to electronic records in 2015 (Kelley et al., 2011).

Prior research has demonstrated that implementing information technology in the health care system has influenced the quality, efficiency, and cost of care. Some studies showed that the use of EHRs improves communication, streamlines the workflow, provides access to patient information, improves adherence to guideline- and protocolbased care, decreases medication errors, and enhances patient safety (Chaudhry et al., 2006). However, other studies reported that some hospitals did not achieve either 
efficiencies or positive influences on health care delivery after implementing the EHR system. All of these studies and their results were included in the systematic review conducted by Chaudhry et al. (2006). However, in the Chaudhry et al. review, they included and analyzed only studies that utilized quantitative methods, and their review focused on analyzing the effect of EHRs on quality, efficiency, and cost of medical care for all cases, not specifically on diabetes.

Added to the importance of this review is the fact that the adoption and "meaningful use" of EHRs is becoming a national priority, to the extent that the National Ambulatory Medical Care Survey (NAMCS) estimates that in 2013, 78\% of office-based physicians used EHR systems (Hsiao \& Hing, 2014). However, less is known about how nurses - as the primary end users of technology systems - and other users (e.g., office managers, chief nurse executives [CNEs]) perceive the effects of EHR implementation on patient care. The definition of meaningful use will be discussed in the section below.

\section{Objectives}

Reviewing prior qualitative studies comprehensively is important as we can obtain detailed information about the nuances and complexities of EHR use in clinical environments that are not reflected in quantitative studies. Therefore, the purpose of this review is to provide an integrative literature review on qualitative studies that address the following primary research question: "How do nurses and other users perceive the effects of EHR implementation on patient care?"

Four major concepts are discussed in this review: EHR, meaningful use, perception, and patient care. EHR is defined as "an electronic version of a patient's medical history, that is maintained by the provider over time, and may include all of the 
key administrative clinical data relevant to that persons care under a particular provider" (Centers for Medicare and Medicaid Services [CMS], 2012). The Centers for Disease Control and Prevention [CDC] (2012) defines meaningful use as "the use of certified EHR in a meaningful manner as governed by the CMS EHR Incentive Programs." The CMS EHR Incentive Program provides an incentive payment for eligible hospitals, eligible professionals, and critical access hospitals when they adopt, use, and demonstrate that they meet the CMS EHR meaningful use criteria (CMS, 2014). In terms of perception, the Oxford Dictionary (2014) defines perception as "a way of regarding, understanding, or interpreting something." Finally, patient care is defined as, "the services rendered by members of the health profession and non-professionals under their supervision for the benefit of the patient" (Dorland's illustrated medical dictionary, 1994).

The review will discuss the chosen studies' research questions, theoretical/conceptual frameworks and data collection methods, findings/conclusions, literature gaps, and implications for future studies. The results of this study will help guide future research, hospital administration, and policy.

\section{Literature search methods}

A comprehensive literature search was conducted using electronic databases, particularly EBSCOHost, PubMed, MEDLINE, ScienceDirect, OVID, and CINAHL. The keywords used in the query were "electronic health records and nurses' perceptions and qualitative" and "EHR and quality of care and qualitative." The inclusion criteria for the literature were 1) papers published between 2007 and 2014, 2) research articles, 3) papers and articles written in English, and 4) papers and articles using qualitative methodologies. 
Figure 1. Literature Search and Sorting Process using PRISMA Flow Diagram ${ }^{2}$
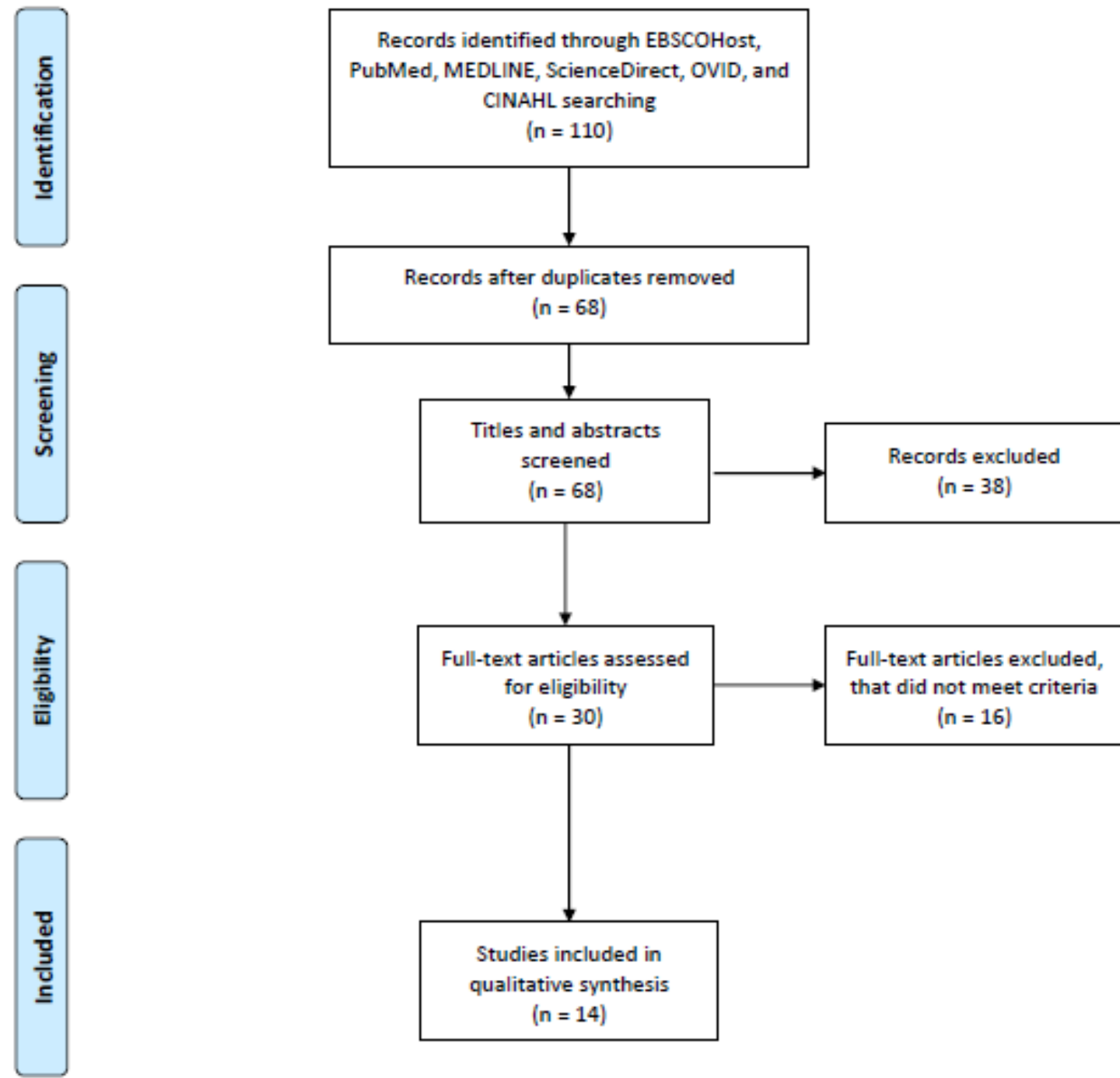

"PRISMA Flow Diagram adapted from Moher D, Liberati A, Tetzlaff J, Altman DG, The PRISMA Group (2009).

Figure 1 shows how the qualitative studies were screened and selected for this review. The initial search yielded a total of 110 records. After duplicate studies were removed, only 68 records remained. Inclusion criteria were used to screen the titles and abstracts of 68 records, leaving 30 articles. However, after all 30 articles were skimmed and scanned based on the research question of this review, only 14 articles were found to 
have investigated the nurses' and other users' perceptions on the impact of EHR use on patient care.

\section{Results}

\subsection{Overview of the selected studies}

Of the 14 selected studies, eight had only nurses as their participants, five had nurses and physicians as their participants, and one had only physicians as its participants. Regarding the country where the studies were conducted, twelve were from the US, one was from Australia, and one was from Sweden. In terms of research settings, the selected studies were conducted in ambulatory medical practices, primary care practices, nursing homes, community hospitals, pediatric hospitals, teaching hospitals, urban hospitals, emergency departments (EDs), acute wards, medical-surgical units, and oncology units. Purposive, convenience, and stratified purposive sampling methods were used in these selected articles.

Furthermore, data collection time varied among the 14 studies. One study collected its data one month after EHR implementation (Whittaker et al., 2009). Five studies collected their data three months after EHR implementation (Carrington, 2012; Carrington \& Effken, 2011; Crosson et al., 2007; Ventres et al., 2006; Zadvinskis et al., 2014). One study collected its data five months post-EHR (Yoon-Flannery et al., 2008). Three studies collected data at six months post-EHR (Culler et al., 2011; Kossman \& Scheidenhelm, 2008; Rantz et al., 2011). One study obtained data from its participants 16 months after EHR use (Callen et al., 2013). Two studies collected data one year postEHR (Piscotty \& Tzeng, 2011; Stevenson \& Nilsson, 2011). Finally, one study collected 
the perception of its participants 5 years after EHR implementation (Laramee, Bosek, Kasprisin, \& Powers-Phaneuf, 2011).

In two articles the researchers used different terms for EHRs, such as clinical information systems (CISs) and electronic medical records (EMRs). Two studies focused only on a specific part of EHRs, i.e., the electronic medication administration record (eMAR) system and e-prescribing.

\subsection{Research questions formulated in the selected literature}

A good qualitative study addresses clearly stated research questions (Frankel \& Devers, 2000). In this integrative literature review, only three articles had research questions that aimed to obtain the views or perceptions of nurses and other users regarding the effects of EHR implementation on patient care (Callen et al., 2013; Kossman \& Scheidenhelm, 2008; Laramee et al., 2011). The other 11 articles did not clearly state any research questions. Even so, the study purposes of those 11 articles were explicitly stated in their Introduction and Methods sections as summarized below.

Of the 11 studies, three aimed to explore nurses' perceptions of the strengths and limitations of the EHR implementation (Carrington \& Effken, 2011; Carrington, 2012; Stevenson \& Nilsson, 2011). Two studies intended to investigate nurses' perceptions of facilitators and barriers to the implementation of the EHR (Culler et al., 2011; Whittaker et al., 2009). One study aimed to explore nurses' perceptions regarding the effectiveness of EHR implementation on workflow, satisfaction, and care quality (Zadvinskis et al., 2014). Two studies targeted nurse and system leaders concerning their perspectives on how to successfully implement EHRs (Piscotty \& Tzeng, 2011; Yoon-Flannery et al., 2008). One study explored the effect of EHR use on the physician-patient relationship 
(Ventres et al., 2006). One study aimed to obtain viewpoints from physicians and other users regarding factors that affect the implementation and use of e-prescribing in ambulatory settings (Crosson et al., 2007). Lastly, one study targeted nursing home employees in an investigation of their views about the use of EHRs on patient care quality (Rantz et al., 2011).

\subsection{Theoretical/conceptual frameworks used in the selected literature}

In this integrative literature review, only four of 14 articles clearly stated their conceptual and theoretical frameworks. Two studies clearly stated that elements of Information Theory were used as their conceptual framework (Carrington \& Effken, 2011; Carrington, 2012). The elements of this theory consist of the relationships among information source, device, destination, redundancy, probability, and noise. On the basis of this conceptual framework, the authors described that for their research, the documenting nurse was conceptualized as the information source, the EHR was conceptualized as the device, and the receiving nurse was conceptualized as the destination. Moreover, nurses' perceptions of the strengths of EHRs were conceptualized as redundancy, and nurses' perceptions of the limitations of EHRs were conceptualized as noise. Overall, the conceptual framework for the two studies was well-developed and well-defined.

Another study that also emphasized its conceptual framework was conducted by Piscotty and Tzeng (2011). The authors clearly mentioned that their study was based on Donabedian's Healthcare Quality Model which consists of three main concepts: structure, process, and outcome. The structure for their research was the CIS implementation readiness activities, the process was the clinical decision-making and 
actions of the chief nurse executives (CNEs), and the outcome was how well the healthcare system functioned after the CIS implementation.

In addition to the three studies above, Whittaker et al. (2009) explicitly stated that they used the Staggers and Parks Nurse-Computer Interaction Framework to study nurses' perceptions of barriers and facilitators to the EHR adoption. According to the Staggers and Parks's framework, nurse characteristics, computer characteristics, and the context in which nurses use the EHR are the main phenomena that may affect nurses' acceptance of the EHR. The remaining ten articles did not explicitly state their conceptual or theoretical frameworks. However, the ten studies directly explained their research designs, participants, and methods used for collecting their data (Callen et al., 2013; Crosson et al., 2007; Culler et al., 2011; Kossman \& Scheidenhelm, 2008; Laramee et al., 2011; Rantz et al., 2011; Stevenson \& Nilsson, 2011; Ventres et al., 2006; Yoon-Flannery et al., 2008; Zadvinskis et al., 2014).

\subsection{Types of data collection methods used in the selected studies}

All of the selected studies used qualitative methods to collect their data. However, none of those studies explicitly stated that they used a triangulation method for their data collection. Instead, they stated that they used multiple qualitative methods to obtain their data. The following section will discuss the qualitative methods utilized individually and together in the selected studies, including individual interviews, focus group interviews, observation, and surveys.

Seven of the 14 studies only used individual interviews for data collection. Six studies used semi-structured questions, and one study used both open-ended and semistructured questions. Individual interviews ranged in length from 20 to 60 minutes. 
Below are the seven studies that used individual interviews to answer their research questions.

The following studies utilized individual interviews to explore nurses' perceptions of the strengths and limitations of EHR implementation. Carrington and Effken (2011) and Carrington (2012) conducted 20-30 minute semi-structured interviews to obtain data from 37 registered nurses (RNs) regarding their perceptions of the strengths and limitations of the EHR with and without nursing languages in documenting and retrieving patient information related to a clinical event.

Two other studies used individual interviews to investigate nurses' perceptions of facilitators and barriers to the implementation of the EHR. Culler et al. (2011) explored nurses' perceptions of facilitators and barriers to the implementation of the eMAR system. In their study, 14 participants were interviewed using semi-structured questions at 6 months and 18 months after the EHR implementation. However, only 13 interviews were completed at 18 months after EHR use. Whittaker et al. (2009) interviewed 11 RNs using semi-structured questions that lasted between 30 and 60 minutes. The purpose of their study was to explore nurses' perceptions of the facilitators and barriers to the implementation of the EHR in a rural hospital.

Individual interviews were also used in the study conducted by Zadvinskis et al. (2014), who used qualitative research methodology to discover nurses' perceptions of how EHR implementation affects the quality of patient care and work of healthcare providers. Zadvinskis et al. (2014) interviewed ten nurses using semi-structured questions to explore their perceptions and expectations of EHRs and their impact on workflow, satisfaction, and quality of care. 
The last two studies that used individual interviews were conducted by Piscotty and Tzeng (2011) and Yoon-Flannery et al. (2008). In their study, Piscotty and Tzeng (2011) used both open-ended and semi-structured interviews for data collection. Each interview in this research lasted between 40 and 70 minutes. A total of six CNEs were interviewed about the CIS implementation readiness activities they adopted in their hospitals. Yoon-Flannery et al. (2008) conducted a study investigating the perspectives of 31 system leaders on best practices for an ambulatory EHR implementation. To collect data for their study, they used 45-minute semi-structured questions.

In five other studies, individual and focus group interviews were used along with other qualitative methods, such as observation, surveys, and videotaped encounters for data collection. For instance, Laramee et al. (2011) collected data using semi-structured focus group interviews with content analysis and evaluative surveys. A total of 40 interdisciplinary healthcare team members participated in 11 focus groups to discuss factors that may lead to the successful implementation of EHRs and strategies that may prove effective in overcoming barriers.

Another example was a study conducted by Ventres et al. (2006) who used four methods - individual and focus group interviews, videotaped encounters, and participant observation - to collect their data as part of their ethnographic study. Using these methods allowed the researchers to perform an intense analysis of patient and physician behaviors in examination rooms.

Rantz et al. (2011) also utilized focus group interviews along with field interviews and observation to collect data from four nursing home employees, specifically about whether the use of bedside EMR may improve quality of care in nursing facilities. A total 
of 120 employees participated in 22 focus groups, and all interview texts were analyzed using content analysis. Likewise, Callen et al. (2013) used individual and focus group interviews along with structured observations to obtain data from physicians and nurses regarding their perceptions of the effect of an integrated ED information system on the quality of care delivered in the ED. A total of 97 physicians and nurses participated in this study. Of these 97 participants, 69 were individually interviewed and 28 participated in five focus groups. In addition, these 97 participants were observed for 26 hours.

Finally, Stevenson and Nilsson (2011) also used focus-group interviews of 21 nurses who were assigned to four groups. In four focus-group interviews, all participants were asked about their perceptions of using EHRs in their daily practice.

Regarding observation, no studies in the selected articles relied solely on observation to collect their data. However, the researchers in four studies utilized observation and combined it with other data collection methods, such as questionnaire surveys and individual, key informant, in-depth, and focus group interviews (Callen et al., 2013; Crosson et al., 2007; Kossman \& Scheidenhelm, 2008; Rantz et al., 2011).

Finally, Kossman and Scheidenhelm (2008) utilized surveys, individual interviews, and observation techniques to describe nurses' experiences with EHR use in community hospitals. First the researchers administered surveys with open-ended questions to explore the boundaries of the phenomenon of how nurses use EHRs and perceive its impact on work performance and outcomes. Second, the researchers observed nurses' use of EHRs and interviewed them concurrently. These observations and interviews allowed the researchers to identify practice patterns and problems encountered with EHR use. The investigators could also directly see how nurses solved those EHR 
problems. Laramee et al. (2011) initially conducted focus group interviews. Afterwards, they analyzed the focus group data, developed, and distributed a seven-item questionnaire to the units' staff to validate the themes identified in the focus groups.

\subsection{Findings of the selected literature}

Twelve studies reported that the use of EHRs had positive impacts on patient care, whereas seven studies claimed that the use of EHRs also had negative effects on patient care and suggested strategies to, first, prepare for the implementation of the EHR, and second, improve the EHR. Therefore, the findings of the selected articles were grouped into three main themes and discussed: positive perceptions, negative perceptions, and strategies to improve the effective implementation of EHRs.

\subsubsection{Positive perceptions about the effects of EHR implementation on patient care}

Twelve studies found positive perceptions regarding the effect of EHRs on patient care, including improved communication, facilitated simultaneous access to patient information, improved patient flow, increased legibility of clinical documentation, enhanced quality of care, and clinicians able to make faster decisions. Thus, four themes emerged in the discussion of the clinicians' positive perceptions of the EHR: facilitated clinical decision-making, enhanced coordination and communication, usability and enhanced clinical information documentation, and improved quality of patient care.

\subsubsection{Facilitated clinical decision-making}

Three studies concluded that the EHR system can be used to facilitate clinical decision making based on the viewpoints of physicians and nurses. For instance, a study conducted by Callen et al. (2013) found that in the EDs that have integrated EHRs, physicians and nurses reported that the system had a positive impact on clinical decision- 
making compared to the stand-alone ED information system (Callen et al., 2013). Using EHRs, clinicians can easily gain access to patient-specific clinical information and clinical databases that help them to make a faster and better clinical decisions for their patients (Callen et al., 2013). Two other studies found that after the implementation of EHRs, access to patient information improved (Culler et al., 2011; Kossman \& Scheidenhelm, 2008). Therefore, nurses, as the participants in these two studies, perceived positively the adoption of EHRs because they enhanced their ability to do their job (Culler et al., 2011; Kossman \& Scheidenhelm, 2008).

\subsubsection{Enhanced coordination and communication}

Four studies reported that clinicians in their studies agreed that using the EHR system improved coordination between clinicians within and outside the unit. This coordination was perceived positively because physicians and nurses, for example, in EDs, can access the same patient information that is linked to data in other hospitals in the region. Furthermore, the EHR system with its synchronous access allows physicians and nurses to have faster and better access to patient data simultaneously. This access improves the process of patient care, particularly enhancing the speed of patient flow from one unit to another, and better efficiency and communication among clinicians and between departments (Callen et al., 2013; Culler et al., 2011; Rantz et al., 2011;

Stevenson \& Nilsson, 2011).

\subsubsection{Usability and improved clinical information documentation}

Five studies concluded that the physicians and nurses in their studies had positive perceptions about the use of the EHR system for improving patient care, especially with regard to its usability and its capacity to improve clinical information documentation. 
Physicians and nurses in five studies confirmed that the EHR system has many clinical benefits during the care process, including less written documentation, increased legibility of clinicians' notes, reduced time for documentation, increased accuracy, and improved documentation (i.e., more complete and more comprehensive) (Callen et al., 2013; Rantz et al., 2011; Whittaker et al., 2009; Yoon-Flannery et al., 2008; Zadvinskis et al., 2014). Clinicians working in the medical-surgical units and ICU reported they perceived the retrievability to be a strength of the EHR in that it enhanced communication and increased efficiency (Carrington \& Effken, 2011; Kossman \& Scheidenhelm, 2008). Ease of locating information documented on charts and ease of use were the two other benefits of the EHR system that encouraged nurses to positively perceive the adoption of this system (Culler et al., 2011; Whittaker et al., 2009).

\subsubsection{Improved quality of patient care}

Six of 14 studies reported that nurses and physicians supported the use of EHRs due to their advantages in enhancing the quality of patient care. Nurses in the study conducted by Carrington (2012) reported that the use of EHRs with standardized nursing languages improved the patient care planning associated with a clinical event. In addition, physicians working in ambulatory practices reported that the e-prescribing system integrated into an EHR system helps to manage patients with chronic illness (Crosson et al., 2007). Nurses working in children's hospitals and community hospitals perceived that implementing an EHR system reduced transcription errors, which in turn increases patient safety (Culler et al., 2011; Kossman \& Scheidenhelm, 2008; Zadvinskis et al., 2014). Furthermore, all patient information, such as patient allergies, is saved and 
used as baseline information for future medical treatments. For these reasons the EHR system can improve patient safety (Stevenson \& Nilsson, 2011).

Another reason clinicians perceived positively the use of the EHR system was its facilitation of physician-patient relationships depending on the following factors: spatial, relational, educational, and structural (Ventres et al., 2006). Spatial factors comprise monitor position, accessibility of EHR, and flow of encounter. Relational factors were the physicians' styles of using the EHR system in encounters with patients. Educational factors include the training plan for using the EHR system, patient education, and patients' understandings. Structural factors include financial costs, EHR notes, organizational culture, and evolution of technology (Ventres et al., 2006).

\subsubsection{Negative perceptions about the effects of EHR implementation on patient care}

Despite the positive perceptions found in the studies reported above, seven studies reported clinicians' negative perceptions of the effects of EHRs on patient care. In one study, nurses complained about difficulties in getting a quick overview of patients' conditions. They needed to search through many different sections of EHRs to obtain important information about their patients. They preferred to have a verbal report of the important data concerning their patients' conditions (Stevenson \& Nilsson, 2011). Clinicians' lack of computer skills and knowledge were other factors that caused the nurses to experience difficulties in using the EHR system. The nurses spent more time dealing with computer issues than providing direct patient care. These issues led to negative perceptions of the EHR system (Callen et al., 2013; Kossman \& Scheidenhelm, 2008; Rantz et al., 2011; Whittaker et al., 2009). Standardized nursing language used in the EHR system was perceived as difficult to use and created barriers to documentation 
(Carrington, 2012; Carrington \& Effken, 2011). This was mainly due to the nursing languages used in the EHR system not being standard English, but legal language (Carrington, 2012).

\subsubsection{Strategies for the effective implementation of EHRs}

In addition to positive and negative perceptions of nurses and other users, three of 14 studies provided strategies for the effective implementation of EHRs (Laramee et al., 2011; Piscotty \& Tzeng, 2011; Yoon-Flannery et al., 2008). According to these studies, all clinicians should be better informed about the benefits of the EHR system.

Furthermore, well-staffed technical support and its availability during the EHR system's go-live period were perceived to be important by clinicians who had successfully implemented EHRs in their workplaces (Laramee et al., 2011). Identification of champions, training in how to use the EHR system, staff preparation for change, patient privacy, system migration, vendor support, and financial considerations were activities that CNEs and system leaders believed should be executed prior to the EHR adoption process (Piscotty \& Tzeng, 2011; Yoon-Flannery et al., 2008).

\section{Literature gaps}

Thirteen qualitative studies used the appropriate sampling method for qualitative research design, particularly purposive sampling, convenience sampling, and stratified purposive sampling. One study used self-selection sampling to recruit their participants (Laramee et al., 2011). Self-selection sampling has advantages and disadvantages for qualitative studies. The advantages are that it takes less time to find participants when they self-select; in addition, the participants are more committed to being involved in the study, compared to participants in other types of sampling. Nevertheless, the 
disadvantages of this self-selection sampling are that the participants may not be representative of the studied population. Furthermore, this sampling method can lead to self-selection bias (Polit \& Beck, 2012). This review identified a methodological issue found in the 14 studies: only three studies clearly stated their research questions and only four studies explicitly stated their conceptual and theoretical frameworks.

Although the majority of the selected literature explored nurses' and other users' perceptions about the effects of EHR implementation on patient care, the time period used for data collection post-EHR implementation might be considered too early $(\leq 1.5$ years) (Ammenwerth et al., 2003). Less than 1.5 years is considered to be a time of transition. The findings would be more accurate if clinicians were interviewed in person or in a group and observed for at least two years post-EHR implementation (Ammenwerth et al., 2003). Using that time frame allows for conversion of all paperbased records into electronic-based records.

\section{Implications for administrative decisions, policy, and future studies}

The findings of this review offer support for EHRs being implemented in various health care systems, such as ambulatory medical practices, nursing homes, community hospitals, urban hospitals, EDs, and oncology units. Furthermore, the results of this review, particularly the positive effects of EHR implementation on patient care and strategies to improve the effective implementation of EHRs, offer better information to hospital administrators and policy makers regarding what benefits to expect from the EHR use and how best to implement the EHR system in order to improve the quality and efficiency of patient care. Another finding of this review, the negative perceptions of nurses and users regarding the influence of EHRs on patient care, describes some 
situations where users felt EHRs were problematic and not effective. These situations should be considered and addressed by hospital administrators and policy makers before adopting an EHR system in their institutions. Finally, findings of this review can be used to explain the complexities of the EHR implementation based on the users' perspectives that is not concluded in the review of quantitative studies.

\section{Conclusion}

Using qualitative methodology to understand the perceptions of nurses and other users about the effect of EHR implementation on patient care is important because it will help future nursing informatics researchers understand the complexities of the EHR implementation in clinical environments. Finally, the findings of this qualitative review can also be used by future researchers in nursing informatics and nursing management fields to develop instruments and surveys related to EHR implementation and quality of patient care. 


\section{References}

Ammenwerth, E., Mansmann, U., Iller, C., Eichstädter, R., 2003. Factors affecting and affected by user acceptance of computer-based nursing documentation: results of a twoyear study. Journal of the American Medical Association 10 (1), 69-84.

Callen, J., Paoloni, R., Li, J., Stewart, M., Gibson, K., Georgiou, A., Braithwaite, J. Westbrook, J., 2013. Perceptions of the effect of information and communication technology on the quality of care delivered in emergency departments: a cross-site qualitative study. Annals of Emergency Medicine 61 (2), 131-144.

Carrington, J. M., Effken, J. A., 2011. Strengths and limitations of the electronic health record for documenting clinical events. CIN: Computers, Informatics, Nursing 29 (6), 360367.

Carrington, J. M., 2012. The usefulness of nursing languages to communicate a clinical event. CIN: Computers, Informatics, Nursing 30 (2), 82-88.

Centers for Disease Control and Prevention (CDC) (2012) Meaningful use. http://www.cdc.gov/ehrmeaningfuluse/introduction.html accessed 9/1/2013

Centers for Medicare and Medicaid Services (CMS) (2012) Electronic health records. http://www.cms.gov/Medicare/E-

Health/EHealthRecords/index.html?redirect=/ehealthrecords/ accessed 9/1/2013

Centers for Medicare and Medicaid Services (CMS) (2014) Meaningful use. http://www.cms.gov/Regulations-andGuidance/Legislation/EHRIncentivePrograms/Meaningful_Use.html accessed 1/15/2014

Chaudhry, B., Wang, J., Wu, S., Shekelle, P. G., 2006. Systematic review: impact of health information technology on quality, efficiency, and costs of medical care. Annals of Internal Medicine 144 (10), 742-752.

Crosson, J. C., Isaacson, N., Lancaster, D., Bell, D. S., 2007. Variation in electronic prescribing implementation among twelve ambulatory practices. Journal of General Internal Medicine 23 (4), 364-71.

Culler, S. D., Jose, J., Kohler, S., Rask, K., 2011. Nurses' perceptions and experiences with the implementation of a medication administration system. CIN: Computers, Informatics, Nursing 29 (5), 280-288.

DesRoches, C. M., Campbell, E. G., Vogeli, C., Zheng, J., Rao, S. R., Shields, A. E., Jha, A.K., 2010. Electronic health records' limited successes suggest more targeted uses. Health Affairs 29 (4), 639-646.

Dorland's illustrated medical dictionary. 1994. Patient care in Dorland's illustrated medical dictionary (28th ed.). Elsevier Health Sciences, Philadelphia. 
Frankel, R. M., Devers, K. J., 2000. Study design in qualitative research--1: developing questions and assessing resource needs. Education for Health (Abingdon) 13 (2), 251261.

Hsiao C-J., Hing E., 2014. Use and characteristics of electronic health record systems among office-based physician practices: United States, 2001-2013. NCHS data brief, no 143. National Center for Health Statistics, Maryland.

Kelley, T. F., Brandon, D. H., Docherty, S. L., 2011. Electronic nursing documentation as a strategy to improve quality of patient care. Journal of Nursing Scholarship 43 (2), 154162.

Kossman, S., Scheidenhelm, S. L., 2008. Nurses' perceptions of the impact of electronic health records on work and patient outcomes. CIN: Computers, Informatics, Nursing 26 (2), 69-77.

Laramee, A. S., Bosek, M., Kasprisin, C. A., Powers-Phaneuf, T., 2011. Learning from within to ensure a successful implementation of an electronic health record. CIN:

Computers, Informatics, Nursing 29 (8), 468-477.

Oxford dictionaries (2013) Perception.

http://www.oxforddictionaries.com/us/definition/american_english/perception accessed 9/1/2013

Piscotty, R. J., Tzeng, H., 2011. Exploring the clinical information system implementation readiness activities to support nursing in hospital settings. CIN: Computers, Informatics, Nursing 29 (11), 648-656.

Polit,D. F., Beck, C. T., 2012. Nursing research: generating and assessing evidence for nursing practice (9th ed.). Wolters Kluwer Health/Lippincott Williams \& Wilkins, Philadelphia.

Rantz, M. J., Alexander, F. G., Galambos, C., Flesner, M. K., Vogelsmeier, A., Hicks, L., Scott-Cawiezell, J., Zwygart-Stauffacher, M., Greenwald, L., 2012. The use of bedside electronic medical record to improve quality of care in nursing facilities: a qualitative analysis. CIN: Computers, Informatics, Nursing 30 (1), TC3-TC10.

Stevenson, J. E., Nilsson, G., 2012. Nurses' perceptions of an electronic patient record from a patient safety perspective: a qualitative study. Journal of Advanced Nursing 68 (3), 667-676.

The U.S. Department of Health and Human Services (US DHHS). 2009. HITECH Act Enforcement Interim Final Rule. The U.S. Department of Health and Human Services, Washington D.C.

Ventres, W., Kooienga, S., Vuckovic, N., Marlin, R., Nygren, P., Stewart, V., 2006. Physicians, patients, and the electronic health record: an ethnographic analysis. Annals of Family Medicine 4 (2), 124-131. 
Whittaker, A. A., Aufdenkamp, M., Tinley, S., 2009. Barriers and facilitators to electronic documentation in a rural hospital. Journal of Nursing Scholarship 41 (3), 293300 .

Yoon-Flannery, K., Zandieh, S. O., Kuperman, G. J., Langsam, D. J., Hyman, D., Kaushal, R., 2008. A qualitative analysis of an electronic health record (EHR) implementation in an academic ambulatory setting. Informatics in Primary Care 16 (4), 277-84.

Zadvinskis, I.M., Chipps, E., Yen, P., 2014. Exploring nurses' confirmed expectations regarding health IT: a phenomenological study. International Journal of Medical Informatics 83 (2), 89-98. 
Table

Characteristics of Studies Included in Qualitative Study Review

\begin{tabular}{|c|c|c|c|c|c|c|c|}
\hline No. & $\begin{array}{l}\text { First } \\
\text { Author, } \\
\text { (Year), } \\
\text { Country }\end{array}$ & $\begin{array}{c}\text { Research } \\
\text { Questions/Objectives/ } \\
\text { Specific Aims }\end{array}$ & Setting & $\begin{array}{c}\text { Sample } \\
\text { Characteristics }\end{array}$ & Methods & Results & Conclusions \\
\hline 1 & $\begin{array}{l}\text { Callen et al. } \\
\text { (2013), } \\
\text { Australia }\end{array}$ & $\begin{array}{l}\text { Do emergency physicians } \\
\text { and nurses perceive that an } \\
\text { integrated ED information } \\
\text { system affects patient care, } \\
\text { and if so, how? }\end{array}$ & $\begin{array}{l}\text { Four urban } \\
\text { Emergency } \\
\text { Departments } \\
\text { (EDs) }\end{array}$ & $\begin{array}{l}\text { Purposive } \\
\text { sample: } 97 \\
\text { participants } \\
\text { (nurses and } \\
\text { physicians): } 69 \\
\text { participants } \\
\text { were } \\
\text { interviewed } \\
\text { and 28 } \\
\text { participants } \\
\text { involved in 5 } \\
\text { focus-group } \\
\text { interviews. }\end{array}$ & $\begin{array}{l}\text { Individual and } \\
\text { focus-group } \\
\text { interviews and } \\
\text { structured } \\
\text { observations }\end{array}$ & $\begin{array}{l}\text { New perspectives } \\
\text { on how an } \\
\text { integrated ED } \\
\text { information } \\
\text { system was } \\
\text { perceived to affect } \\
\text { incentives for use, } \\
\text { awareness of } \\
\text { colleagues' } \\
\text { activities, and } \\
\text { workflow. }\end{array}$ & $\begin{array}{l}\text { Physicians and } \\
\text { nurses perceived } \\
\text { that the } \\
\text { integrated ED } \\
\text { information } \\
\text { system } \\
\text { contributed to } \\
\text { improvements in } \\
\text { the delivery of } \\
\text { patient care, } \\
\text { enabling faster } \\
\text { and better- } \\
\text { informed } \\
\text { decision-making } \\
\text { and specialty } \\
\text { consultations. }\end{array}$ \\
\hline 2 & $\begin{array}{l}\text { Carrington } \\
\text { (2012), US }\end{array}$ & $\begin{array}{l}\text { To explore nurses' } \\
\text { perceptions of the strengths } \\
\text { and limitations of } \\
\text { standardized nursing } \\
\text { languages in the electronic } \\
\text { health record to } \\
\text { communicate a clinical } \\
\text { event. }\end{array}$ & $\begin{array}{l}\text { Medical, } \\
\text { surgical, and } \\
\text { telemetry } \\
\text { nursing } \\
\text { units. }\end{array}$ & $\begin{array}{l}\text { Purposive } \\
\text { sample: } 37 \\
\text { nurses (20 } \\
\text { documenting } \\
\text { and } 17 \\
\text { receiving } \\
\text { nurses). }\end{array}$ & $\begin{array}{l}20-30 \text { minute } \\
\text { individual } \\
\text { interviews using a } \\
\text { semi-structured } \\
\text { interview format. }\end{array}$ & $\begin{array}{l}\text { Three main } \\
\text { categories } \\
\text { emerged: (1) } \\
\text { language } \\
\text { comprehensivenes } \\
\text { s (professional } \\
\text { separation, care } \\
\text { planning, and ease } \\
\text { of use); (2) } \\
\text { inexactness of the } \\
\text { languages (lacks } \\
\text { descriptiveness, } \\
\text { fosters } \\
\text { inaccuracies, and } \\
\text { semantics); and (3) } \\
\text { language } \\
\text { usefulness. }\end{array}$ & $\begin{array}{l}\text { The implication } \\
\text { of these findings } \\
\text { is that } \\
\text { standardized } \\
\text { nursing } \\
\text { languages may } \\
\text { constrain nurse- } \\
\text { to-nurse } \\
\text { communication } \\
\text { of a clinical } \\
\text { event. }\end{array}$ \\
\hline
\end{tabular}


Table

Characteristics of Studies Included in Qualitative Study Review

\begin{tabular}{|c|c|c|c|c|c|c|c|}
\hline No. & $\begin{array}{l}\text { First } \\
\text { Author, } \\
\text { (Year), } \\
\text { Country }\end{array}$ & $\begin{array}{c}\text { Research } \\
\text { Questions/Objectives/ } \\
\text { Specific Aims }\end{array}$ & Setting & $\begin{array}{c}\text { Sample } \\
\text { Characteristics }\end{array}$ & Methods & Results & Conclusions \\
\hline 3 & $\begin{array}{l}\text { Carrington } \\
\& \text { Effken } \\
\text { (2011), US }\end{array}$ & $\begin{array}{l}\text { To compare nurses' } \\
\text { perceptions of the strengths } \\
\text { and limitations of the } \\
\text { electronic health record with } \\
\text { and without nursing } \\
\text { languages for documenting } \\
\text { and retrieving patient } \\
\text { information regarding a } \\
\text { clinical event. }\end{array}$ & $\begin{array}{l}\text { Two urban } \\
\text { Arizona } \\
\text { hospitals }\end{array}$ & $\begin{array}{l}\text { Convenience } \\
\text { sample: } 37 \\
\text { registered } \\
\text { nurses. }\end{array}$ & $\begin{array}{l}20-30 \text { minute } \\
\text { semi-structured } \\
\text { individual } \\
\text { interviews. }\end{array}$ & $\begin{array}{l}\text { Five categories } \\
\text { emerged: usability, } \\
\text { legibility, } \\
\text { communication, } \\
\text { workarounds, and } \\
\text { collaboration. } \\
\text { Nurses perceived } \\
\text { aspects of usability } \\
\text { as strengths } \\
\text { (retrievability) and } \\
\text { limitations (lack of } \\
\text { efficiency and } \\
\text { barriers) of the } \\
\text { electronic health } \\
\text { record. }\end{array}$ & $\begin{array}{l}\text { These results can } \\
\text { potentially assist } \\
\text { in our } \\
\text { understanding of } \\
\text { nurse-to-nurse } \\
\text { communication } \\
\text { of patient status } \\
\text { associated with } \\
\text { clinical events. } \\
\text { These findings } \\
\text { can also guide } \\
\text { the development } \\
\text { of EHR systems } \\
\text { because nurses } \\
\text { are key users. }\end{array}$ \\
\hline 4 & $\begin{array}{l}\text { Crosson et } \\
\text { al. (2007), } \\
\text { US }\end{array}$ & $\begin{array}{l}\text { To describe the practice } \\
\text { characteristics associated } \\
\text { with implementation and use } \\
\text { of e-prescribing in } \\
\text { ambulatory settings. }\end{array}$ & $\begin{array}{l}12 \\
\text { ambulatory } \\
\text { medical } \\
\text { practices: } 5 \\
\text { Family } \\
\text { Medicine, } 4 \\
\text { General } \\
\text { Internal } \\
\text { Medicine, } 2 \\
\text { Obstetrics } \\
\text { and } \\
\text { Gynecology } \\
\text {, and 1 } \\
\text { Pediatrics. }\end{array}$ & $\begin{array}{l}\text { Purposive } \\
\text { sample: } 16 \\
\text { physicians and } \\
31 \text { staff } \\
\text { members }\end{array}$ & $\begin{array}{l}\text { A comparative } \\
\text { case study using } \\
\text { observation and } \\
\text { individual } \\
\text { interviews of } 12 \\
\text { practices before } \\
\text { and after e- } \\
\text { prescribing } \\
\text { implementation. }\end{array}$ & $\begin{array}{l}\text { Five practices fully } \\
\text { implemented e- } \\
\text { prescribing, } \\
3 \text { installed but with } \\
\text { only some } \\
\text { prescribers or staff } \\
\text { members using the } \\
\text { program, } 2 \\
\text { installed and then } \\
\text { discontinued use, } 2 \\
\text { failed to install. }\end{array}$ & $\begin{array}{l}\text { The results of } \\
\text { this study } \\
\text { indicate that } \\
\text { ambulatory } \\
\text { practice leaders } \\
\text { should plan e- } \\
\text { prescribing } \\
\text { implementation } \\
\text { carefully, } \\
\text { ensuring that all } \\
\text { practice } \\
\text { members are } \\
\text { aware of and } \\
\text { prepared for the } \\
\text { likely effects of } \\
\text { this technology } \\
\text { on prescribing } \\
\text { systems and }\end{array}$ \\
\hline
\end{tabular}


Table

Characteristics of Studies Included in Qualitative Study Review

\begin{tabular}{|c|c|c|c|c|c|c|c|}
\hline No. & $\begin{array}{l}\text { First } \\
\text { Author, } \\
\text { (Year), } \\
\text { Country }\end{array}$ & $\begin{array}{c}\text { Research } \\
\text { Questions/Objectives/ } \\
\text { Specific Aims }\end{array}$ & Setting & $\begin{array}{c}\text { Sample } \\
\text { Characteristics }\end{array}$ & Methods & Results & Conclusions \\
\hline & & & & & & & $\begin{array}{l}\text { clinical } \\
\text { workflow. }\end{array}$ \\
\hline 5 & $\begin{array}{l}\text { Culler et al. } \\
\text { (2011), US }\end{array}$ & $\begin{array}{l}\text { To describe the facilitators } \\
\text { and barriers to the } \\
\text { implementation of electronic } \\
\text { medical administration } \\
\text { record (eMAR) system. }\end{array}$ & $\begin{array}{l}\text { Two } \\
\text { pediatric } \\
\text { hospitals }\end{array}$ & $\begin{array}{l}\text { Purposive } \\
\text { sample: } 24 \\
\text { participants: } \\
14 \text { completed } \\
\text { the interviews } \\
\text { at } 6 \text { months } \\
\text { and } 13 \text { of } 14 \\
\text { participants } \\
\text { completed the } \\
\text { follow up } \\
\text { interviews at } \\
\text { one year later. }\end{array}$ & $\begin{array}{l}30-45 \text { minute } \\
\text { individual } \\
\text { interviews at two } \\
\text { time points (6 and } \\
18 \text { months after } \\
\text { EHR } \\
\text { implementation). } \\
\text { The individual } \\
\text { interviews used } \\
\text { questionnaires } \\
\text { consisting of } \\
\text { open-ended and } \\
\text { semi-structured } \\
\text { questions. }\end{array}$ & $\begin{array}{l}\text { Four major } \\
\text { facilitators to } \\
\text { successful } \\
\text { implementation } \\
\text { were identified, } \\
\text { including a } \\
\text { perception of } \\
\text { reduced } \\
\text { transcription } \\
\text { errors, improved } \\
\text { access to patient } \\
\text { information, } \\
\text { improved } \\
\text { interdepartmental } \\
\text { communication, } \\
\text { and ease } \\
\text { of locating } \\
\text { information within } \\
\text { the chart. } \\
\text { Meanwhile, the } \\
\text { most significant } \\
\text { barrier to EHR } \\
\text { adoption was too } \\
\text { much time spent } \\
\text { trying to log-in to } \\
\text { the system. }\end{array}$ & $\begin{array}{l}\text { This study } \\
\text { confirms the } \\
\text { results from } \\
\text { previous studies } \\
\text { that nurses } \\
\text { perceived the } \\
\text { implementation } \\
\text { of eMAR would } \\
\text { lead to improved } \\
\text { patient safety, } \\
\text { improved } \\
\text { accessibility of } \\
\text { patient } \\
\text { information, } \\
\text { improved } \\
\text { interdepartmenta } \\
1 \\
\text { communications, } \\
\text { and ease of } \\
\text { locating clinical } \\
\text { information. }\end{array}$ \\
\hline 6 & $\begin{array}{l}\text { Kossman \& } \\
\text { Scheidenhel } \\
\text { m (2008), } \\
\text { US }\end{array}$ & $\begin{array}{l}\text { How do community hospital } \\
\text { nurses use EHRs? What } \\
\text { effect do they think EHR use } \\
\text { has on their ability to } \\
\text { perform nursing care? What }\end{array}$ & $\begin{array}{l}\text { Medical- } \\
\text { surgical and } \\
\text { intensive } \\
\text { care units at } \\
\text { two }\end{array}$ & $\begin{array}{l}\text { Convenience } \\
\text { sample: } 46 \\
\text { nurses }\end{array}$ & $\begin{array}{l}\text { Questionnaire } \\
\text { surveys, } \\
\text { individual } \\
\text { interviews, and } \\
\text { observations. }\end{array}$ & $\begin{array}{l}\text { Nurses preferred } \\
\text { electronic health } \\
\text { records to paper } \\
\text { charts and were } \\
\text { comfortable with } \\
\text { technology. }\end{array}$ & $\begin{array}{l}\text { This study offers } \\
\text { support for EHR } \\
\text { use in } \\
\text { community } \\
\text { hospitals and } \\
\text { suggests areas }\end{array}$ \\
\hline
\end{tabular}


Table

Characteristics of Studies Included in Qualitative Study Review

\begin{tabular}{|c|c|c|c|c|c|c|c|}
\hline No. & $\begin{array}{l}\text { First } \\
\text { Author, } \\
\text { (Year), } \\
\text { Country }\end{array}$ & $\begin{array}{c}\text { Research } \\
\text { Questions/Objectives/ } \\
\text { Specific Aims }\end{array}$ & Setting & $\begin{array}{c}\text { Sample } \\
\text { Characteristics }\end{array}$ & Methods & Results & Conclusions \\
\hline & & $\begin{array}{l}\text { effect does EHR use have on } \\
\text { patient outcomes? }\end{array}$ & $\begin{array}{l}\text { community } \\
\text { hospitals }\end{array}$ & & & & $\begin{array}{l}\text { for improvement } \\
\text { in EHR products } \\
\text { to better support } \\
\text { nursing work. }\end{array}$ \\
\hline 7 & $\begin{array}{l}\text { Laramee et } \\
\text { al. (2011), } \\
\text { US }\end{array}$ & $\begin{array}{l}\text { Research questions: } 1 \text {. What } \\
\text { factors do interdisciplinary } \\
\text { healthcare team members at a } \\
\text { rural academic medical } \\
\text { center perceive to have led to } \\
\text { a previous successful } \\
\text { implementation of an EHR? } \\
\text { 2. What strategies do } \\
\text { interdisciplinary healthcare } \\
\text { team members at a rural } \\
\text { academic medical center } \\
\text { perceive as being effective in } \\
\text { overcoming barriers, } \\
\text { addressing expectations, } \\
\text { quelling fears, and helping to } \\
\text { create positive attitudes and } \\
\text { perception during a previous } \\
\text { transition to an EHR? }\end{array}$ & $\begin{array}{l}\text { A rural } \\
\text { academic } \\
\text { medical } \\
\text { center: } \\
\text { emergency } \\
\text { department } \\
\text { (ED) and a } \\
\text { dialysis } \\
\text { department } \\
\text { (DD) }\end{array}$ & $\begin{array}{l}\text { Self-selection } \\
\text { sample: } 40 \\
\text { participants } \\
\text { and divided } \\
\text { into } 11 \text { focus } \\
\text { groups. }\end{array}$ & $\begin{array}{l}\text { A descriptive } \\
\text { exploratory } \\
\text { qualitative } \\
\text { research design } \\
\text { using semi- } \\
\text { structured focus } \\
\text { group interviews } \\
\text { with content } \\
\text { analysis and } \\
\text { evaluative } \\
\text { surveys. }\end{array}$ & $\begin{array}{l}\text { Four themes } \\
\text { emerged: } \\
\text { "It will take one } \\
\text { hundred charts"; } \\
\text { allowing for "self- } \\
\text { discovery" of } \\
\text { individual learning } \\
\text { progression; } \\
\text { establishing and } \\
\text { communicating } \\
\text { "clear processes" } \\
\text { for use of the } \\
\text { electronic record; } \\
\text { and ensuring } \\
\text { adequate support } \\
\text { to facilitate a } \\
\text { "customer- } \\
\text { focused" approach } \\
\text { in learning how to } \\
\text { utilize electronic } \\
\text { documentation. }\end{array}$ & $\begin{array}{l}\text { This study } \\
\text { supports that the } \\
\text { contention that in } \\
\text { addition } \\
\text { to evidence- } \\
\text { based practice } \\
\text { reported at other } \\
\text { institutions, } \\
\text { data should be } \\
\text { obtained from } \\
\text { within the } \\
\text { organization. }\end{array}$ \\
\hline 8 & $\begin{array}{l}\text { Piscotty \& } \\
\text { Tzeng } \\
\text { (2011), US }\end{array}$ & $\begin{array}{l}\text { What are the readiness } \\
\text { activities of chief nurse } \\
\text { executives (CNEs) in regard } \\
\text { to clinical information } \\
\text { system (CIS) } \\
\text { implementation? }\end{array}$ & $\begin{array}{l}\text { One } \\
\text { regional } \\
\text { multi- } \\
\text { hospital } \\
\text { health } \\
\text { system } \\
\text { consisting } \\
\text { of five } \\
\text { teaching }\end{array}$ & $\begin{array}{l}\text { Convenience } \\
\text { sample: } 6 \\
\text { CNEs }\end{array}$ & $\begin{array}{l}\text { A qualitative } \\
\text { descriptive study } \\
\text { using open-ended } \\
\text { and semi- } \\
\text { structured } \\
\text { individual } \\
\text { interviews. }\end{array}$ & $\begin{array}{l}\text { Six themes for CIS } \\
\text { implementation } \\
\text { readiness emerged: } \\
\text { (1) champions, (2) } \\
\text { staff preparation } \\
\text { for change, (3) } \\
\text { training, (4) } \\
\text { alignment with } \\
\text { organization, (5) }\end{array}$ & $\begin{array}{l}\text { A key } \\
\text { recommendation } \\
\text { from this study is } \\
\text { that CNEs } \\
\text { should } \\
\text { not only sit on } \\
\text { committees that } \\
\text { make high-level } \\
\text { decisions }\end{array}$ \\
\hline
\end{tabular}


Table

Characteristics of Studies Included in Qualitative Study Review

\begin{tabular}{|c|c|c|c|c|c|c|c|}
\hline No. & $\begin{array}{l}\text { First } \\
\text { Author, } \\
\text { (Year), } \\
\text { Country }\end{array}$ & $\begin{array}{c}\text { Research } \\
\text { Questions/Objectives/ } \\
\text { Specific Aims }\end{array}$ & Setting & $\begin{array}{c}\text { Sample } \\
\text { Characteristics }\end{array}$ & Methods & Results & Conclusions \\
\hline & & & $\begin{array}{l}\text { hospitals } \\
\text { and one } \\
\text { community } \\
\text { hospital. }\end{array}$ & & & $\begin{array}{l}\text { planning, and (6) } \\
\text { vendor support. }\end{array}$ & $\begin{array}{l}\text { regarding the } \\
\text { CIS. They should } \\
\text { also become } \\
\text { involved } \\
\text { in the } \\
\text { implementation. }\end{array}$ \\
\hline 9 & $\begin{array}{l}\text { Rantz et al. } \\
\text { (2011), US }\end{array}$ & $\begin{array}{l}\text { To test the unique and } \\
\text { combined contributions of } \\
\text { bedside technology to } \\
\text { improving the care of nursing } \\
\text { facility residents. }\end{array}$ & $\begin{array}{l}\text { Four } \\
\text { nursing } \\
\text { homes }\end{array}$ & $\begin{array}{l}\text { Stratified } \\
\text { purposive } \\
\text { sample: } 120 \\
\text { staff members }\end{array}$ & $\begin{array}{l}\text { Qualitative } \\
\text { interviews, } \\
\text { observations, } \\
\text { focus group } \\
\text { discussions. }\end{array}$ & $\begin{array}{l}\text { Administrative and } \\
\text { licensed staff } \\
\text { perceived that } \\
\text { documentation } \\
\text { time decreased, } \\
\text { accuracy } \\
\text { increased, } \\
\text { accessing resident } \\
\text { information was } \\
\text { faster, and } \\
\text { assessment and } \\
\text { communication } \\
\text { about residents and } \\
\text { their condition } \\
\text { improved. }\end{array}$ & $\begin{array}{l}\text { This study } \\
\text { demonstrates that } \\
\text { there is benefit } \\
\text { from a quality- } \\
\text { of-care } \\
\text { perspective in } \\
\text { implementing } \\
\text { and using } \\
\text { bedside EMR in } \\
\text { nursing homes. }\end{array}$ \\
\hline 10 & $\begin{array}{l}\text { Stevenson } \\
\text { et al. } \\
(2011) \text {, } \\
\text { Sweden }\end{array}$ & $\begin{array}{l}\text { To explore nurses' } \\
\text { perceptions of using } \\
\text { electronic patient records in } \\
\text { everyday practice, in general } \\
\text { ward settings. }\end{array}$ & $\begin{array}{l}\text { Six acute } \\
\text { wards in a } \\
\text { district } \\
\text { general } \\
\text { hospital in } \\
\text { the } \\
\text { southeast of } \\
\text { Sweden }\end{array}$ & $\begin{array}{l}\text { Purposive } \\
\text { sample: } 21 \\
\text { nurses from six } \\
\text { wards; five } \\
\text { from two } \\
\text { medical units, } \\
\text { six from two } \\
\text { surgical units, } \\
\text { four from an } \\
\text { orthopaedic } \\
\text { unit, and six } \\
\text { from a stroke } \\
\text { unit. }\end{array}$ & $\begin{array}{l}\text { A qualitative } \\
\text { design with four } \\
\text { focus-group } \\
\text { discussions }\end{array}$ & $\begin{array}{l}\text { The findings } \\
\text { related to patient } \\
\text { safety were } \\
\text { clustered in one } \\
\text { main category: } \\
\text { 'documentation in } \\
\text { everyday practice'. } \\
\text { There were three } \\
\text { sub-categories: } \\
\text { vital signs, } \\
\text { overview and } \\
\text { medication } \\
\text { module. Nurses }\end{array}$ & $\begin{array}{l}\text { The findings } \\
\text { presented in this } \\
\text { paper make an } \\
\text { important } \\
\text { contribution to } \\
\text { knowledge about } \\
\text { nurses' } \\
\text { perceptions of } \\
\text { EPR. }\end{array}$ \\
\hline
\end{tabular}


Table

Characteristics of Studies Included in Qualitative Study Review

\begin{tabular}{|c|c|c|c|c|c|c|c|}
\hline No. & $\begin{array}{l}\text { First } \\
\text { Author, } \\
\text { (Year), } \\
\text { Country }\end{array}$ & $\begin{array}{c}\text { Research } \\
\text { Questions/Objectives/ } \\
\text { Specific Aims }\end{array}$ & Setting & $\begin{array}{c}\text { Sample } \\
\text { Characteristics }\end{array}$ & Methods & Results & Conclusions \\
\hline & & & & & & $\begin{array}{l}\text { reported that the } \\
\text { electronic patient } \\
\text { record did not } \\
\text { support nursing } \\
\text { practice when } \\
\text { documenting } \\
\text { crucial patient } \\
\text { information, } \\
\text { such as vital signs. }\end{array}$ & \\
\hline 11 & $\begin{array}{l}\text { Ventres et } \\
\text { al. (2006), } \\
\text { US }\end{array}$ & $\begin{array}{l}\text { To identify how EHRs affect } \\
\text { the encounter between } \\
\text { physicians and their patients. }\end{array}$ & $\begin{array}{l}\text { Four } \\
\text { primary care } \\
\text { practices in } \\
\text { the Pacific } \\
\text { Northwest. }\end{array}$ & $\begin{array}{l}\text { Convenience } \\
\text { sample: } 52 \\
\text { patients, } 12 \\
\text { office staff } \\
\text { members, } 23 \\
\text { physicians, and } \\
1 \text { nurse- } \\
\text { practitioner } \\
\text { were included } \\
\text { in individual } \\
\text { interviews. } 29 \\
\text { physician- } \\
\text { patient } \\
\text { encounters. } 5 \\
\text { focus group } \\
\text { interviews. }\end{array}$ & $\begin{array}{l}\text { A descriptive } \\
\text { study using } \\
\text { ethnographic } \\
\text { design. Data were } \\
\text { collected by using } \\
\text { individual and } \\
\text { focus group } \\
\text { interviews, video- } \\
\text { taped encounters, } \\
\text { participant } \\
\text { observation. }\end{array}$ & $\begin{array}{l}14 \text { factors were } \\
\text { identified } \\
\text { concerning how } \\
\text { EHR uses affect } \\
\text { the encounter } \\
\text { between } \\
\text { physicians and } \\
\text { their patients. } \\
\text { These factors were } \\
\text { grouped into } 4 \\
\text { themes: spatial, } \\
\text { relational, } \\
\text { educational, and } \\
\text { structural. }\end{array}$ & $\begin{array}{l}\text { This study found } \\
\text { that the } \\
\text { introduction of } \\
\text { EHRs into } \\
\text { practices } \\
\text { influences } \\
\text { multiple } \\
\text { cognitive and } \\
\text { social } \\
\text { dimensions of } \\
\text { the clinical } \\
\text { encounter. }\end{array}$ \\
\hline 12 & $\begin{array}{l}\text { Whittaker et } \\
\text { al (2009), } \\
\text { US }\end{array}$ & $\begin{array}{l}\text { To explore nurses' } \\
\text { perceptions of barriers and } \\
\text { facilitators to the adoption of } \\
\text { an electronic health record } \\
\text { (EHR) in a rural } \\
\text { Midwestern hospital. }\end{array}$ & $\begin{array}{l}\text { Oncology } \\
\text { and } \\
\text { medical- } \\
\text { surgical } \\
\text { units }\end{array}$ & $\begin{array}{l}\text { Purposive } \\
\text { sample: } 11 \\
\text { RNs }\end{array}$ & $\begin{array}{l}30-60 \text { minute } \\
\text { individual } \\
\text { interviews with } \\
\text { semi-structured } \\
\text { questions. }\end{array}$ & $\begin{array}{l}\text { Participants were } \\
\text { able to identify } \\
\text { computer-related, } \\
\text { nurse-related, and } \\
\text { contextual barriers } \\
\text { and facilitators to } \\
\text { the } \\
\text { implementation of } \\
\text { EHR. }\end{array}$ & $\begin{array}{l}\text { Acceptance and } \\
\text { use of an EHR } \\
\text { are enhanced } \\
\text { when barriers are } \\
\text { managed and } \\
\text { facilitators are } \\
\text { supported. }\end{array}$ \\
\hline
\end{tabular}


Table

Characteristics of Studies Included in Qualitative Study Review

\begin{tabular}{|c|c|c|c|c|c|c|c|}
\hline No. & $\begin{array}{c}\text { First } \\
\text { Author, } \\
\text { (Year), } \\
\text { Country }\end{array}$ & $\begin{array}{c}\text { Research } \\
\text { Questions/Objectives/ } \\
\text { Specific Aims }\end{array}$ & Setting & $\begin{array}{c}\text { Sample } \\
\text { Characteristics }\end{array}$ & Methods & Results & Conclusions \\
\hline 13 & $\begin{array}{l}\text { Yoon- } \\
\text { Flannery et } \\
\text { al. (2008), } \\
\text { US }\end{array}$ & $\begin{array}{l}\text { To determine pre- } \\
\text { implementation leadership } \\
\text { perspectives regarding best } \\
\text { practice for two ambulatory } \\
\text { electronic health records } \\
\text { (EHRs) at an academic } \\
\text { institution. }\end{array}$ & $\begin{array}{l}\text { A large } \\
\text { academic } \\
\text { institution in } \\
\text { New York } \\
\text { City. }\end{array}$ & $\begin{array}{l}\text { Purposive } \\
\text { sample: } 31 \\
\text { system leaders: } \\
\text { ambulatory } \\
\text { care network } \\
\text { (ACN) } \\
\text { leadership, } \\
\text { information } \\
\text { systems (IS) } \\
\text { leadership, } \\
\text { practice } \\
\text { leadership } \\
\text { (medical } \\
\text { directors and } \\
\text { practice } \\
\text { managers) and } \\
\text { vendor } \\
\text { leadership }\end{array}$ & $\begin{array}{l}45 \text { minute-semi- } \\
\text { structured } \\
\text { individual } \\
\text { interviews that } \\
\text { were tailored to } \\
\text { the type of } \\
\text { respondent. }\end{array}$ & $\begin{array}{l}\text { Respondents } \\
\text { perceived benefits } \\
\text { of EHR use, } \\
\text { particularly that } \\
\text { EHR would } \\
\text { improve access to } \\
\text { patient data, } \\
\text { improve } \\
\text { communication } \\
\text { among } \\
\text { practitioners, } \\
\text { improve quality } \\
\text { measurement, } \\
\text { allow practitioners } \\
\text { to retrieve } \\
\text { population-based } \\
\text { data, and improve } \\
\text { continuity of care. } \\
\text { Six important } \\
\text { themes regarding } \\
\text { respondents' } \\
\text { expectations for } \\
\text { the EHR } \\
\text { implementation } \\
\text { emerged: } \\
\text { communication; } \\
\text { system migration; } \\
\text { technical } \\
\text { equipment, } \\
\text { support, and } \\
\text { training; patient } \\
\text { privacy; } \\
\text { efficiency; and }\end{array}$ & $\begin{array}{l}\text { This study offers } \\
\text { some important } \\
\text { aspects of } \\
\text { implementation } \\
\text { planning and } \\
\text { suggests } \\
\text { some potential } \\
\text { best practices } \\
\text { that other } \\
\text { institutions } \\
\text { may find useful } \\
\text { in adopting } \\
\text { EHRs. }\end{array}$ \\
\hline
\end{tabular}


Table

Characteristics of Studies Included in Qualitative Study Review

\begin{tabular}{|c|c|c|c|c|c|c|c|}
\hline No. & $\begin{array}{l}\text { First } \\
\text { Author, } \\
\text { (Year), } \\
\text { Country }\end{array}$ & $\begin{array}{c}\text { Research } \\
\text { Questions/Objectives/ } \\
\text { Specific Aims }\end{array}$ & Setting & $\begin{array}{c}\text { Sample } \\
\text { Characteristics }\end{array}$ & Methods & Results & Conclusions \\
\hline & & & & & & $\begin{array}{l}\text { financial } \\
\text { considerations. }\end{array}$ & \\
\hline 14 & $\begin{array}{l}\text { Zadvinskis } \\
\text { et al. } \\
\text { (2014), US }\end{array}$ & $\begin{array}{l}\text { To assess nurses' perceptions } \\
\text { and expectations of EHR and } \\
\text { its impact on workflow, } \\
\text { satisfaction and quality of } \\
\text { care. }\end{array}$ & $\begin{array}{l}\text { A medical- } \\
\text { surgical unit } \\
\text { in an } \\
\text { academic } \\
\text { center }\end{array}$ & $\begin{array}{l}\text { Purposive } \\
\text { sample: Ten } \\
\text { nurses }\end{array}$ & $\begin{array}{l}\text { A } \\
\text { phenomenologica } \\
1 \text { approach using } \\
20-60 \text { minute } \\
\text { semi-structured } \\
\text { individual } \\
\text { interviews with } \\
\text { additional probes } \\
\text { to clarify and } \\
\text { discover } \\
\text { in-depth } \\
\text { information 3-4 } \\
\text { months after EHR } \\
\text { implementation. }\end{array}$ & $\begin{array}{l}\text { Five themes } \\
\text { emerged from } \\
\text { personal-level to } \\
\text { organizational- } \\
\text { level confirmed } \\
\text { expectations: (1) } \\
\text { nurses' interaction } \\
\text { with computers, } \\
\text { (2) nursing } \\
\text { performance } \\
\text { regarding task } \\
\text { accomplishment, } \\
\text { (3) unit-specific } \\
\text { teamwork, (4) } \\
\text { interdisciplinary } \\
\text { teamwork, and (5) } \\
\text { quality of care. }\end{array}$ & $\begin{array}{l}\text { Nurses' } \\
\text { perceptions of } \\
\text { health IT } \\
\text { implementation } \\
\text { vary according to } \\
\text { level of } \\
\text { expectation. }\end{array}$ \\
\hline
\end{tabular}




\title{
CHAPTER FOUR
}

\section{Manuscript Two}

\section{"The Effects of Using Electronic Health Records on the Quality of Diabetes Care: An Integrative Literature Review"}

(To be submitted to the Computers, Informatics, Nursing)

\begin{abstract}
Author names and credentials: Rini Rachmawaty, MN, RN (Indonesia); Marianne Baernholdt, PhD, MPH, RN; Susan Huerta, PhD, RN; Myra Clark, PhD, RN, FNP-C.
\end{abstract}

Author affiliations: School of Nursing, University of Virginia, Charlottesville and Faculty of Medicine, Hasanuddin University, Makassar, Indonesia (Ms. Rachmawaty); School of Nursing and Department of Public Health Sciences, University of Virginia, Charlottesville (Dr. Baernholdt); Froedtert hospital (Dr. Huerta); and School of Nursing, University of Virginia, Charlottesville (Dr. Clark).

Corresponding author: Rini Rachmawaty, MN, RN (Indonesia), School of Nursing, University of Virginia, McLeod Hall, Room \#5031 (Doctoral Lounge), 202 Jeanette Lancaster Way, Charlottesville, VA 22903 (rr7bz@virginia.edu).

Funding information: The first author received a Fulbright Presidential Scholarship (2010-2013) to study for a PhD in nursing at the University of Virginia. This research is conducted as part of her $\mathrm{PhD}$ program. 


\begin{abstract}
This integrative review identified the effects of electronic health records (EHRs) on the quality of diabetes care. The specific questions guiding the review were as follows: How is quality of diabetes care measured? What are the effects of EHR use on quality of diabetes care? CINAHL, OVID and PubMed databases were searched for papers published in English between 2006 and 2014. A total of 230 records were retrieved; 11 articles were retained. Findings show that these 11 articles used different guidelines to measure quality of diabetes care, but the main components of these guidelines were derived from the same source, the National Diabetes Quality Improvement Alliance (NDQIA). The effect of EHR use on the process of diabetes care and intermediate outcomes were examined in all 11 studies. Six studies reported significant improvements in diabetes care processes, particularly $\mathrm{HbA1c}$, eye, foot, and BP measurements; and nephropathy screening after EHR implementation. Two studies demonstrate that EHRs can improve both diabetes care and intermediate outcome (i.e., BP). However, three studies argued that EHR use did not improve the quality of diabetes care. The findings of this review conclude that EHR use tended to improve quality of diabetes care (processes and intermediate outcomes), mainly in primary care and community-based practices. Nevertheless, as of 2013, 22\% of practices had not adopted an EHR system. Consequently, the results of this review can be used as evidence for hospital administrators to consider the advantages of EHR adoption.
\end{abstract}

Keywords: diabetes; electronic health records; quality of care 


\section{INTRODUCTION}

In 2011, diabetes affects 20.8 million adults aged 18 years and above in the United States (US). ${ }^{1}$ Diabetes is a chronic disease that decreases quality of life as it can cause microvascular and macrovascular complications, which can lead to disability or

death. ${ }^{2}$ In addition to the presence of complications, type of diabetes, level of $\mathrm{HbA} 1 \mathrm{c}$, and patient characteristics such as age, gender, race, and income, are some other factors that can affect quality of life of patients diagnosed with diabetes. ${ }^{3}$ Besides diminishing quality of life, elevated HbA1c level and diabetes complications may increase risks for hospital readmissions and, therefore, escalate health care costs. ${ }^{4}$ Considering the impact of diabetes, particularly increased use of high intensity services associated with high cost, improved health care quality that includes coordinated care is needed to manage these patients. As defined by Donabedian in 1988, quality of care is, "that kind of care which is expected to maximize an inclusive measure of patient welfare....." ${ }^{5(\mathrm{p} 1745)}$ In the health care system, quality of care can be assessed from structure, process, and outcome. In this review, the term quality of care will be used frequently.

The implementation of electronic health records (EHRs) has also been suggested for improving quality of health care ${ }^{6-7}$ and preventing and managing chronic diseases. ${ }^{2}$ In this review, we will introduce and discuss factors affecting quality of life of patients diagnosed with diabetes, the importance of EHRs, and findings from the past studies regarding the use of EHRs and their impact on the quality of care in general. Finally, we will present the purpose of this integrative literature review, methodology, and findings. 


\section{Type of Diabetes and Its Impact on Quality of Life}

As mentioned previously the type of diabetes is one factor that can diminish quality of life. ${ }^{3}$ This section will describe types of diabetes and explain the difference between type 1 and type 2 diabetes and their effects on the patient's quality of life.

A diagnosis of diabetes is determined based on one of the following criteria: level of glycosylated hemoglobin $(\mathrm{HbA} 1 \mathrm{c}) \geq 6.5 \%$, or the fasting plasma glucose level $\geq 126$ $\mathrm{mg} / \mathrm{dL}(7.0 \mathrm{mmol} / \mathrm{L})$, or the 2-hour plasma glucose level $\geq 200 \mathrm{mg} / \mathrm{dL}(11.1 \mathrm{mmol} / \mathrm{L})$ during an oral glucose tolerance test, or the random plasma glucose $\geq 200 \mathrm{mg} / \mathrm{dL}$ (11.1 $\mathrm{mmol} / \mathrm{L}$ ) for patients with classic symptoms of hyperglycemia, including polydipsia, polyuria, and polyphagia. ${ }^{8}$

Diabetes has four clinical classes based on the causes: type 1 diabetes, type 2 diabetes, gestational diabetes, and other specific types of diabetes. ${ }^{9}$ Type 1 diabetes occurs when the pancreas cannot produce insulin (autoimmune), while type 2 diabetes develops due to the combination of genetic and lifestyle factors. ${ }^{9}$ Gestational diabetes mellitus (GDM) is caused by changes in hormones and metabolic demands of pregnancy, which are also associated with genetic and environmental factors. ${ }^{9}$ Other specific types of diabetes are those caused by hereditary defects in beta-cell function, by genetic defects in insulin action, and by exocrine pancreas diseases, and those induced by drugs or chemicals. ${ }^{9}$

According to Rubin and Peyrot, patients diagnosed with type 2 diabetes who are not taking insulin had a higher quality of life than patients taking insulin based on the assessment results using the Short Form (36) health survey and the Diabetes Quality of Life (DQOL) questionnaire. ${ }^{3}$ Even so, patients with type 2 diabetes taking insulin had a 
better quality of life than those patients with type 1 diabetes taking insulin. ${ }^{3}$ In the US, $90-95 \%$ of adults diagnosed with diabetes are categorized as having type 2 diabetes. $^{8}$ Although patients diagnosed with type 2 diabetes have better quality of life than those patients diagnosed with type 1 diabetes, the effort to decrease number of persons diagnosed with types 1 and 2 diabetes remains problematic. The Centers for Disease Control and Prevention (CDC) reported that the number of persons diagnosed with diabetes increased by $74.2 \%$, from 12 million in 2000 to 20.9 million in $2011 .^{10}$ The national cost of diabetes in the US also rose by $40.8 \%$, from $\$ 174$ billion in 2007 to $\$ 245$ billion in $2012 .{ }^{11}$ Therefore, it is important to understand how diabetes can affect quality of patients' lives and how it can influence the cost of health care in the US. The following two sections will discuss diabetes-related complications and will convey the impact of uncontrolled diabetes on quality of life. Then, hospital readmissions will be discussed to show how the cost of diabetes affects the US economy.

\section{Diabetes-Related Complications}

Complications in diabetes are known as microvascular and macrovascular complications. ${ }^{9}$ These complications occur when patients diagnosed with diabetes do not control their condition or receive or adhere to the recommended diabetes therapy. ${ }^{8-9}$ Diabetes-related complications include cardiovascular disease (CVD), stroke, mortality due to hyperglycemic crises, diabetic ketoacidosis (DKA), end-stage renal disease related to diabetes mellitus (ESRD-DM), lower extremity disease (e.g., peripheral arterial disease, ulcer/inflammation/infection, or neuropathy), lower extremity amputation, and visual impairment including blindness. ${ }^{10}$ In 2011, the number of adults aged 35 years and above diagnosed with both diabetes and either heart disease or stroke increased by 
$80.9 \%$, from 4.2 million in 1997 to 7.6 million in $2011 .{ }^{10}$ Meanwhile the number of deaths from hyperglycemic crises rose from 2,274 in 2004 to 2,417 in $2009 .{ }^{10}$

Similarly, hospital discharges from diabetic ketoacidosis increased by $75 \%$, from about 80,000 discharges in 1988 to about 140,000 in $2009 .{ }^{10}$ Likewise, the number of patients diagnosed with diabetes initiating treatment for ESRD-DM rose 18-fold, from 2,644 in 1980 to 48,374 in $2008 .{ }^{10}$ Furthermore, the number of hospital discharges of patients diagnosed with diabetes with lower extremity diseases doubled from 445,000 in 1988 to 890,000 in $2007 .{ }^{10}$ Similar trends emerged in the number of hospital discharges for non-traumatic lower extremity amputation with diabetes, which rose by $24 \%$ from 1988 to $2009 .{ }^{10}$ Diabetic retinopathy was also reported to have increased by $48 \%$ from 1997 to 2009 among adults diagnosed with diabetes aged 18 years or older. ${ }^{10}$

More patients diagnosed with diabetes and those suffering from diabetes complications may have a devastating effect on the quality of patients' lives, such as disability and death, ${ }^{6}$ which lead to a heavy burden on the US health care system. ${ }^{12}$ One important contributor to the cost issue is hospital readmissions. ${ }^{13}$

\section{Hospital Readmissions}

As mentioned above, the hospital readmission is one of the causes of the increase in the US economic cost of diabetes. ${ }^{13} \mathrm{HbA} 1 \mathrm{c}$ levels and patient characteristics are the two major factors that predict higher readmission rates. ${ }^{14-15}$

A study conducted by Menzin et al. demonstrated that patients with mean HbA1c $\geq 10 \%$ were more likely to have one or more diabetes-related hospitalizations than those with mean HbA1c < 7\% (33.9\% versus 19.5\%). ${ }^{14}$ Furthermore, another study conducted by Bennett et al. showed that patient characteristics are associated with hospital 
readmissions. Their study found that diabetes-related readmissions were higher in Hispanics and non-Hispanic blacks, females, older people, and those covered by Medicare or Medicaid. ${ }^{15}$ Likewise, readmissions were reported to be higher in those who had more comorbidities, a longer length of stay, a 30-day follow-up physician visit, and those who lived in low-income areas or in a county without a hospital. ${ }^{16}$

Besides HbA1c levels and patient characteristics, lack of coordinated care can lead to readmissions. For instance, after being discharged, patients diagnosed with diabetes with complex health care needs often seek care in multiple settings (e.g., inpatient and outpatient) and across specialties (e.g., primary care and specialty care, for example, with an ophthalmologist, a dietician, etc. $).{ }^{15}$ If these patients do not receive proper treatment or if their treatment is not coordinated among health care providers, hospital readmissions may increase. Consequently, medical care costs will rise and increase the national economic burden of diabetes. A study conducted by Maciejewski and Maynard found that there are three factors affecting the total cost of diabetes: 1) the prevalence of diabetes, 2) the types of health services utilized by each patient, and 3) the fee for health care services. ${ }^{17}$ In the US, the economic cost of diabetes has increased significantly from $\$ 194$ billion in 2010 to $\$ 245$ billion in 2012 . Hence, it is important to provide better quality of care for patients diagnosed with diabetes. Provision of outpatient glycemic control is recommended as it can reduce readmissions. ${ }^{13}$

However, to be able to provide better quality of diabetes care, it is important to understand how quality of diabetes of care is measured in the health care system (i.e., structure, process, and outcome) and what guidelines can be used to evaluate quality of diabetes care. 


\section{Electronic Health Records (EHRs)}

As mentioned previously, adopting EHRs is one of the recommended solutions for improving health care quality or effectiveness, increasing health care productivity or efficiency, reducing health care costs, and improving tracking of chronic disease management. ${ }^{7,18} \mathrm{EHR}$ is defined as a longitudinal electronic record that contains complete patient health information generated from one or more clinical encounters in any care delivery setting. ${ }^{19}$ Under the American Recovery and Reinvestment Act (ARRA) of 2009, hospitals across the US are expected to become meaningful users of EHRs by the year $2014 .^{20}$

Meaningful use (MU) is defined as using the certified EHR technology in a meaningful manner to improve quality, efficiency, and care coordination, as governed by the Centers for Medicare \& Medicaid Services (CMS) Incentive Programs. ${ }^{21}$ There are three stages of MU: in stage 1 (2011-2012), the EHR system was adopted for the main purpose of data capture and sharing. In stage 2 (2014), the EHR system is expected to be used for improving clinical process. Finally, in stage 3 (2016), the use of EHRs is expected to enhance outcomes. ${ }^{22}$

The CMS offers incentive payments to eligible providers and hospitals in return for becoming meaningful users of EHRs between 2009 and $2014 .{ }^{23}$ In Stage 1, to receive incentive payments, health care providers must demonstrate that EHRs in their hospitals or practices have been meaningfully used, which means they must meet 19 of $24 \mathrm{MU}$ objectives. ${ }^{24-25}$ The objectives include use of the computerized provider order entry (CPOE) for medication orders, maintenance of active medication lists, recording and charting changes in vital signs, and incorporation of clinical lab test results. ${ }^{24}$ In Stage 2, 
the eligible professionals and hospitals can receive incentive payment if they show that they have met all MU objectives in Stage 1 and Stage $2 .{ }^{26}$ The additional MU objective for Stage 2 is the use of secure electronic messaging to communicate with patients about pertinent health information. ${ }^{26}$ In 2015 , financial penalties will be applied to hospitals that have not converted to electronic-based records. ${ }^{27}$ The National Ambulatory Medical Care Survey (NAMCS) reported that in 2013, $22 \%$ of office-based physicians have not used the EHR system. ${ }^{28}$

Research has examined the effect of EHRs on health care quality in general; the results of those studies were mixed. Some studies reported that hospitals with EHRs had better patient safety and other quality outcomes compared to hospitals without EHRs. ${ }^{7,18,27,29-31}$ However, other studies reported that using the EHR system was not associated with an improvement in quality of care. ${ }^{32-33}$ Furthermore, no review specifically discussed the impact of EHRs on quality of care for a specific chronic disease, such as diabetes.

The aim of this integrative review was to identify study results regarding the effect of EHR use on quality of diabetes care. The specific questions were, first, how is quality of diabetes care measured? Second, what are the effects of EHR use on quality of diabetes care?

\section{METHODS}

A comprehensive literature search was conducted using the electronic databases provided by CINAHL, OVID, and PubMed. Keywords used in the search included "electronic health records and quality of care and diabetes," "EHR and diabetes care and outcome," and "electronic health records and quality of diabetes care." The search was 
limited to research articles written in English and published between 2006 and 2014.

Dissertations, theses, reviews, and other documents were excluded.

Figure 1 shows the literature search process and sorting by using a PRISMA flow diagram. A total of 230 records were retrieved during the initial search. Duplicates were removed, leaving 105 records. Afterwards the titles and abstracts of these records were screened based on the inclusion criteria. Then, 58 articles were retrieved but only 11 articles focused on the implementation of EHR and its impact on quality of care.

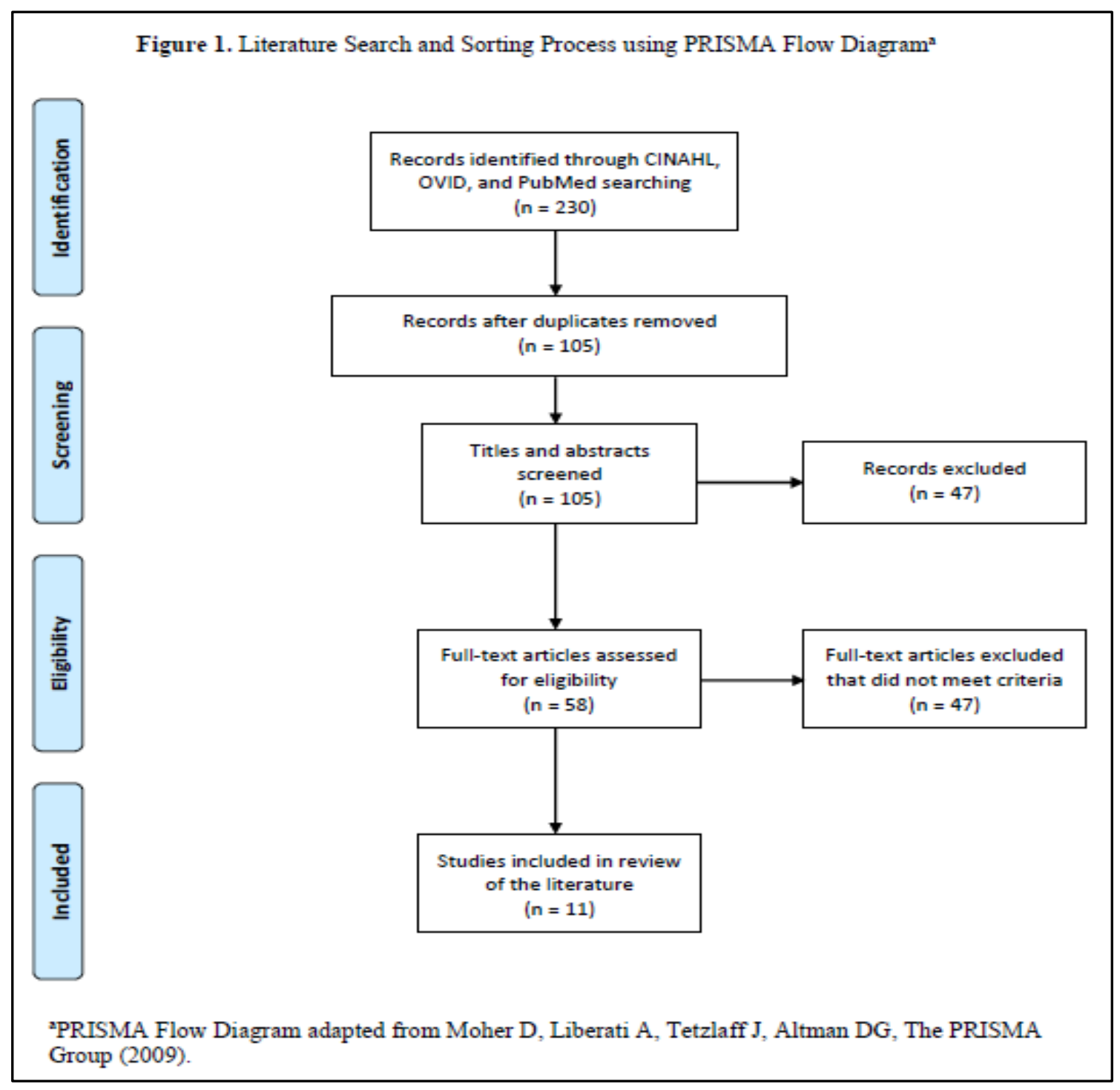




\section{RESULTS}

\section{Overview of the Selected Studies}

Ten studies originated in the United States (US) and one study in the Netherlands. Study designs in the selected literature were longitudinal studies $(n=6)$, cross-sectional studies $(n=3)$, and pre-posttest studies $(n=2)$. Nine studies were set in primary care practices and two studies in community-based practices. The duration of the studies ranged from cross-sectional comparisons to five years of follow-up. Three studies examined the effect of EHR use on quality of diabetes care, whereas the remaining articles focused only on the impact of EHR use on the process of diabetes care.

\section{Measuring Quality of Diabetes Care}

In 1997 the Diabetes Quality Improvement Program (DQIP) and more than 25 health care organizations developed a set of quality performance measures to evaluate quality of diabetes care in a standardized manner. ${ }^{34-35}$ In 2005 , the quality performance measurement set for diabetes was updated by the National Diabetes Quality Improvement Alliance (NDQIA) with the approval of 13 organizations. These included the Agency for Healthcare Research and Quality (AHRQ), the American Diabetes Association (ADA), the American Medical Association (AMA), the CDC, the CMS, and the Joint Commission on Accreditation of Healthcare Organizations (JCAHO). ${ }^{35-37}$ Thus, NDQIA is considered to be the most widely applicable and includes the most accurate measures for assessing quality of diabetes care. The quality performance measures for diabetes care have been adopted and revised by the National Committee for Quality Assurance (NCQA) and incorporated into the 2013 Healthcare Effectiveness Data and Information 
Set (HEDIS) measures. HEDIS is used by $90 \%$ of American health plans to measure health provider performance on important dimensions of care and service. ${ }^{38}$

The diabetes quality performance measures consist of two measures: process measures and outcome measures. Process measures are defined as measures that reflect diabetes care guidelines. ${ }^{35,37}$ Outcome measures consist of two types of measures: intermediate outcome measures and long-term outcome measures. Intermediate outcome measures are defined as measures used to achieve specific clinical care thresholds, for example, physiological or biochemical values, which may positively or adversely influence the desired health outcome ${ }^{39}$ Finally, long-term outcome measures are defined as measures including complications and mortality, which are not ideal to assess over the short-term..$^{35}$

According to the NDQIA, diabetes quality performance measures consist of eight process measures (HbA1c, BP, and lipid management; screening for urine protein; examination of the eyes and feet; influenza vaccination; and use of aspirin) and five intermediate outcome measures $(\mathrm{HbA} 1 \mathrm{c}, \mathrm{BP}$, and lipid management; pregnancy counseling; and recommendations for smoking cessation). ${ }^{37}$

Quality of diabetes care in 11 studies was assessed using various measurements, which have similar components to those in the NDQIA. Three studies used HEDIS measures, ${ }^{40-42}$ two studies used guidelines from the ADA, ${ }^{43-44}$ one study used guidelines from the AMA Physician Consortium Adult Diabetes Measure set, ${ }^{45}$ and five studies used guidelines developed by the investigators of research projects. ${ }^{46-50}$

In HEDIS, process measures for diabetes consist of HbA1c testing, eye examinations, cholesterol testing, and nephropathy monitoring. ${ }^{40-42}$ However, ADA 
measurement of diabetes care quality is more comprehensive. In this measurement, quality of diabetes care is assessed by measuring adherence to guidelines in 3 areas: processes of care, treatment, and achievement of intermediate outcomes. ${ }^{43-44}$ ADA process measures include $\mathrm{HbA1c}$ and smoking status assessed within the last 6 months, low-density lipoprotein cholesterol (LDL-C) and urine microalbumin assessed within the last 12 months, and BP recorded at each of 3 previous visits. ${ }^{43-44} \mathrm{ADA}$ treatment goals include 1) HbA1c $\leq 8 \%$ for patients who have a history of severe hypoglycemia or HbA1c $>8 \%$ for the initiation of the hypoglycemic agent; 2) LDL-C $\leq 100 \mathrm{mg} / \mathrm{dL}$ for patients diagnosed with type 2 diabetes or LDLD-C $>100 \mathrm{mg} / \mathrm{dL}$ for the initiation of the lipidlowering agent in individuals with established CHD; and 3) $\mathrm{BP} \leq 130 / 85 \mathrm{mmHg}$ (systolic and diastolic) for patients diagnosed with diabetes or $\mathrm{BP}>130 / 85 \mathrm{mmHg}$ (systolic or diastolic) for the initiation of the antihypertensive. ${ }^{43-44} \mathrm{ADA}$ intermediate outcome measures include $\mathrm{HbA} 1 \mathrm{c}<7 \%$, LDL-C $\leq 100 \mathrm{mg} / \mathrm{dL}$, and $\mathrm{BP} \leq 130 / 85 \mathrm{mmHg}$ (systolic and diastolic). ${ }^{43-44}$

In the AMA Physician Consortium Adult Diabetes Measure set, process measures consist of 11 components: measurement of HbA1c, BP, lipids (cholesterol and tryglycerides), and renal function (microalbumin, urinanalysis, eye examination, foot examination, influenza vaccine, aspirin, and smoking assessment). ${ }^{45}$ Furthermore, AMA outcome measures consist of $\mathrm{HbA} 1 \mathrm{c} \leq 8 \%$, BP $<130 / 80 \mathrm{mmHg}$, and LDL $<100 \mathrm{mg} / \mathrm{dL} .{ }^{45}$

To sum up, the above-mentioned strategies measured the process of diabetes care. However, only the ADA, AMA, and NDQIA measured both process and intermediate outcomes of diabetes care. Components assessed by these three organizations for process and intermediate outcomes of diabetes care were similar. 


\section{Electronic Health Records and Diabetes Care Quality}

Findings from the studies conducted to examine the effect of EHR use on quality of diabetes care varied. Eight studies reported that EHR use was effective in improving the quality of diabetes care. ${ }^{40-42,44-48,}$ However, three studies claimed that EHR use was not associated with any improvement in diabetes care quality. ${ }^{43,49-50}$ All findings from the selected studies, mainly the impact of EHR use on process of diabetes care and intermediate outcomes, are explained in more detail below.

\section{Effect of EHR Use on the Process of Diabetes Care}

As mentioned above, eight studies demonstrated positive improvements in quality of diabetes care. Using the HEDIS measures, Friedberg et al., Kern et al., and Ryan et al., conducted studies to examine the effect of EHR use on the process of diabetes care in primary care practices. Friedberg et al. and Kern et al. used cross-sectional designs, while Ryan et al. used a 3-year retrospective longitudinal study. ${ }^{40-42}$ These three studies concluded that frequent use of multifunctional EHRs was significantly associated with better performance on eye/retinal examinations, ${ }^{40-42}$ nephropathy monitoring, ${ }^{40} \mathrm{HbA} 1 \mathrm{c}$ testing ${ }^{41}$, and urine testing. ${ }^{42}$

Likewise, DeVoe et al. used the ADA guidelines to examine whether EHR data of patients diagnosed with diabetes and receiving preventive care services in US community health centers (CHCs) were more accurate than data in the Medicaid claims. ${ }^{44}$ Using a 3year longitudinal retrospective study, they found that the percentages of patients who had influenza vaccination, microalbumin screen, LDL screen, and HbA1c test documented in EHRs were consistently higher in CHCs than in Medicaid claims. ${ }^{44}$ 
Significant improvements in the process of diabetes care after EHR implementation was evident in four studies. ${ }^{45-48}$ Cebul et al. and Herrin et al. conducted longitudinal studies (three years and five years, respectively) to examine the impact of EHR use on quality of diabetes care by comparing primary care practices with EHRs to primary care practices with paper-based records. ${ }^{45-46}$ To measure the quality of diabetes care, Cebul et al. used nine quality standards for diabetes care approved by Better Health's Clinical Advisory Committee, while Herrin et al. used the AMA Physician Consortium Adult Diabetes Measure set. ${ }^{45-46}$ Both studies found that primary care practices with EHRs achieved better results in some process measures for diabetes care. ${ }^{45-46}$ Herrin et al. found significant improvements in BP control, microalbumin screening, eye and foot examinations, influenza vaccine, aspirin use, and smoking assessment. ${ }^{45}$ Meanwhile, in Cebul et al. found significant improvements in the HbA1c, kidney management (i.e., urinary microalbumin), eye examinations, and pneumococcal vaccination. $^{46}$

In addition to the studies by Cebul et al. and Herrin et al., Fleurant et al. and Linder et al. discovered that EHR use affected the process of diabetes care. ${ }^{47-48}$ Fleurant et al. conducted pre-post intervention surveys to measure physicians' ability to generate registries for laboratory results and medication use in the care of patients with chronic diseases. ${ }^{47}$ Registries are defined as "list of patients with specific conditions, medications, and test results. ${ }^{, 47(\mathrm{p} 1256)}$ In their study, they found that as more physicians utilized EHRs, there was an increase in generated registries to remind patients diagnosed with diabetes that they were due for follow-up testing. ${ }^{47}$ 
Meanwhile, Linder et al. conducted a cross-sectional analysis to examine whether primary care physicians who use the EHR more deliver better quality diabetes care depending on their documentation styles in EHRs. ${ }^{48}$ Three documentation styles were compared: dictation, structured documentation, and free text. ${ }^{48}$ They found that physicians' quality of care was significantly better when they used structured documentation for two process measures (BP and diabetic foot examination), compared to that of physicians using the other two documentation styles. ${ }^{48}$ Furthermore, the quality of care appeared to be significantly better when physicians used free text for one measure, influenza vaccination. ${ }^{48}$ Nevertheless, physicians' quality of care significantly worsened when they employed dictation for one measure, diabetic eye examination. ${ }^{48}$ They concluded that quality of diabetes care assessed by EHRs depended on the type of documentation. Overall, physicians using structured documentation delivered better quality of diabetes care than those using dictation.

Despite eight studies documenting positive improvements in the process of diabetes care, three studies reported that EHR use was not associated with such improvements. Crosson et al. conducted a study to compare chronic illness care outcomes associated with the use of EHR records and paper records. ${ }^{43}$ After conducting the 3-year longitudinal study, they did not find any differences in meeting the recommended process of diabetes care (HbA1c tests, urine microalbumin screening, smoking status, LDL-C measurement, and BP recording) between EHR and paper-based practices ${ }^{43}$ Similarly, a retrospective longitudinal study conducted by Linmans et al. (2012) in 10 EHR-primary care practices in the Netherlands discovered no significant changes in average HbAlc over time in 2,549 patients diagnosed with diabetes. ${ }^{49}$ Finally, Welch et al. supported 
results from Crosson et al. and Linmans et al., finding that EHR use had no significant effect on diabetes care. ${ }^{50}$

To conclude, of the 11 studies included in this review, eight demonstrated that there were significant improvements in the process of diabetes care when EHRs were utilized. Nevertheless, three studies found there was no significant difference in diabetes care before and after EHR implementation. The following section will discuss whether or not the implementation of EHRs can affect the intermediate outcomes of diabetes care.

\section{Effect of EHR Use on the Intermediate Outcomes of Diabetes Care}

Intermediate outcomes of diabetes care are measured based on the proportion of patients achieving the recommended levels of HbA1c, BP, LDL-C, BMI, and nonsmoking status. Of the eight studies that showed significant improvement in diabetes care quality after EHR implementation, only three examined the effect of EHR use on intermediate outcomes of diabetes care. ${ }^{43,45-46}$ Two studies showed positive improvements in intermediate outcomes of diabetes care, but one study showed no significant results after EHR implementation. ${ }^{45-46}$

In the study conducted by Cebul et al. the percentage of patients diagnosed with diabetes met at least four of the five intermediate outcome measures (HbA1c <8\%, BP $<140 / 80 \mathrm{mmHg}$, LDL-C $<100 \mathrm{mg} / \mathrm{dL}, \mathrm{BMI}<30 \mathrm{~kg} / \mathrm{m}^{2}$, and non-smoking status). This finding was higher at EHR sites than at paper-based sites (43.7\% versus $15.7 \%) .{ }^{46}$ Similarly, Herrin et al. revealed that the percentage of patients diagnosed with diabetes achieved two intermediate outcome measures (BP $<130 / 80 \mathrm{mmHg}$ and non-smoking status), which was significantly greater in the EHR exposed group than in the non-EHR exposed group. ${ }^{45}$ In contrast, Crosson et al. detected no difference between EHR and 
paper-based practices in achieving the recommended intermediate outcomes (HbA1c

$<7 \%$, LDL-C $<100 \mathrm{mg} / \mathrm{dL}$, and $\mathrm{BP}<130 / 85 \mathrm{mmHg}) .{ }^{43}$

In conclusion, two of the three studies assessing the effect of EHR use on

intermediate outcomes of diabetes care showed that patients achieved the recommended intermediate outcome measures following the implementation of EHRs. Another study revealed no significant difference occurred in intermediate outcomes of diabetes care before and after EHR implementation.

\section{DISCUSSION}

The aims of this integrative review were to understand how quality of diabetes care was measured and to identify the effect of EHR use on quality of diabetes care found by past studies. To address the first aim, this review showed that all studies use different measurements to assess quality of diabetes care. The ADA guidelines, the AMA Physician Consortium Adult Diabetes Measure set, and the HEDIS measures were used more often in the selected studies. Even so, the NDQIA is considered to be the most complete set of measures for assessing diabetes care quality as it was approved by 13 health care organizations, including the ADA, the AMA, and the NCQA (the organization that adopted the NDQIA and incorporated it into the HEDIS measures). Therefore, this review suggests that future studies should utilize the NDQIA to measure quality of diabetes care because it is more accurate and it has components that are similar to those in the ADA, AMA, and HEDIS. Only one process measure - pregnancy counseling - in the NDQIA was not measured in the 11 studies.

With regard to Stage 1 EHR MU objectives, the NDQIA guidelines are aligned with three of $24 \mathrm{MU}$ core objectives for the EHR incentive payment, particularly 
recording and charting changes in vital signs, maintaining an active medication list (i.e., for Statins), recording smoking status for patients aged 13 years and above, and incorporating clinical lab-test results. Therefore, measuring the quality of diabetes care using the NDQIA is more complete as it contains elements of documentation that are also included in the EHR meaningful use criteria.

For the second aim, this review indicates that EHR implementation can improve the quality of diabetes care (process and intermediate outcomes). Six studies demonstrate positive improvements in the process of diabetes care after EHR implementation. ${ }^{40-42,44,47-}$ ${ }^{48}$ Of these six studies, significant improvements in HbA1c measurements are found in three studies, ${ }^{41,44,46}$ eye examinations in three studies, ${ }^{40,45-46}$ foot examinations in two studies, ${ }^{45,48} \mathrm{BP}$ controls in two studies, ${ }^{45,48}$ and nephropathy screening in five studies. ${ }^{40,42,44-46}$ Only two studies demonstrate that EHR use can improve both the process of diabetes care and recommended intermediate outcomes. ${ }^{45-46}$ For intermediate outcomes, only BP is found to have significantly improved in two studies after EHR implementation $(<140 / 80 \mathrm{mmHg})$. Meanwhile, three studies did not show any significant improvements either in the process of diabetes care or in intermediate outcomes. ${ }^{43,49-50}$

The results indicate that although the design, setting, and duration of the studies are similar, their findings are different. For instance, Cebul et al. and Crosson et al. use longitudinal studies set in primary care practices and carried out over three years. ${ }^{43,46}$ However, their findings are totally different. While Cebul et al. support the use of EHR to improve quality of diabetes care, ${ }^{46}$ Crosson et al. do not. ${ }^{43}$ These two studies had very different sample sizes and characteristics. In Cebul et al.'s study, the quality of diabetes care was measured using a total of 27,207 patients who live in the Cuyahoga County, 
Ohio. This county includes Cleveland, which is one of the poorest large cities in the US. ${ }^{46}$ Meanwhile, in Crosson et al.'s study, the quality of diabetes care was measured only from a total of 763 patients who resided in New Jersey and Pennsylvania. ${ }^{43}$ Thus, the discrepancy in total sample size and the vulnerability of the sample might have affected these results.

Apart from sample size and patient characteristics, numbers of practices where patient data were extracted from are also different. In the Cebul et al. study, patient data were queried from 46 practices: 33 were EHR-based practices and 13 were paper-based practices. In contrast, Crosson et al. in their study retrieved patient data from 42 practices: 16 were EHR practices and 26 were non-EHR practices. The difference in numbers of practices with and without EHRs probably explained another reason for the discrepancy found in these two studies' results. Furthermore, the two studies did not determine changes in achieving the intermediate outcomes after EHR exposure; they only evaluated the process and intermediate outcomes between EHR practices and non-EHR practices. Moreover, these two studies did not examine how the EHR is used (the EHR workflow), whether or not the EHR features are similar between practices using EHRs, and who input patient data into the EHR system (nurses, physicians, or assistants) while the physicians communicate with the patients.

\section{Literature Gaps}

The results of this review show that quality of diabetes care was measured using different patients who were admitted to different practices where EHR systems/vendors probably varied. This variance might account for the studies that did not indicate any significant results. Consequently, reducing such variance needs to be considered in future 
research. In addition, the longitudinal studies included in this review did not examine changes in the process and intermediate outcomes of diabetes care in the same patients at several points over the study period. Using this research method would yield more compelling findings to demonstrate the benefits of EHRs.

The findings of this review suggest that future research utilize the same guidelines to measure quality of diabetes of care. As the NDQIA has more complete components and has been approved by 13 organizations, including the ADA, AMA and NCQA, their guidelines should be employed in future studies to assess diabetes care quality.

\section{Limitations}

Despite extensive searching, it is possible that studies focusing on EHRs and quality of diabetes care might have been missed. Studies in languages other than English and grey literature, such as doctoral theses/dissertations, reports, and conference proceedings, may have some relevant information for this review but were not accessed.

\section{CONCLUSION}

This integrative literature review revealed many significant findings related to EHRs and quality of diabetes care. The results clearly highlight that EHR use enhances quality of diabetes care (process and intermediate outcomes) in primary care and community-based practices. In 2013 it was evident that $78 \%$ of office-based physicians in the US have adopted the EHR system and 69\% will participate in the CMS EHR incentive program to get financial payment if they can demonstrate that they have meaningfully used the EHR system. The results of this review can be used as evidence for hospital administrators to consider implementing EHRs. Further research is required in this area, particularly longitudinal studies with large sample sizes (based on the 
statistical power analysis) and reduced variance by examining the same patients over time. In addition, as diabetes can diminish the quality of a patient's life due to complications, measures for quality of life should be included in future studies. Finally, we suggest that future studies utilize the NDQIA to measure quality of diabetes care because it is accurate and complete, and it aligns with the Stage 1 and Stage 2 MU core objectives. 


\section{REFERENCES}

1. National diabetes fact sheet: National estimates and general information on diabetes and prediabetes in the United States, 2011. The Centers for Disease Control and Prevention (CDC) Website. http://www.cdc.gov/diabetes/pubs/pdf/ndfs_2011.pdf Published May 2011. Accessed September 19, 2012.

2. Ali MK, Shah S, Tandon N. Review of electronic decision-support tools for diabetes care: a viable option for low-and middle-income countries? J Diabetes Sci Technol. 2011;5(3):553-570.

3. Rubin RR, Peyrot M. Quality of life and diabetes. Diabetes Metab Res Rev. 1999;15:205-218.

4. Fast Facts: Data and Statistics about Diabetes. The American Diabetes Association website. http://professional.diabetes.org/admin/UserFiles/0\%20\%20Sean/FastFacts\%20March\%202013.pdf. Published March 2013. Accessed December 1, 2013.

5. Donabedian A. Quality of care: how can it be assessed? Journal of American Medical Association. 1988;260(12):1743-1748.

6. Ahmad FS, Tsang T. Diabetes prevention, health information technology, and meaningful use: challenges and opportunities. Am J Prev Med. 2013;44(4S4):S357S363.

7. Chaudhry B, Wang J, Wu S, et al. Systematic review: impact of health information technology on quality, efficiency, and costs of medical care. Ann Intern Med. 2006;144:742-752. 
8. American Diabetes Association. Diagnosis and classification of diabetes mellitus. Diabetes Care. 2011;34(1):S62-S69.

9. Standards of Medical Care in Diabetes - 2013. The American Diabetes Association website.

http://care.diabetesjournals.org.proxy.its.virginia.edu/content/36/Supplement_1/S11.f ull.pdf+html. Published January, 2013. Accessed January 14, 2013.

10. Diabetes Public Health Resource. The Centers for Disease Control and Prevention (CDC) Website. http://www.cdc.gov/diabetes/statistics/prevalence_national.htm. Published November 2013. Accessed December 1, 2013.

11. The cost of diabetes. The American Diabetes Association website. http://www.diabetes.org/advocacy/news-events/cost-of-diabetes.html. Accessed March 7, 2014.

12. Huang ES, Brown SES, Wigman BGE, Oley ECF, Eltzer OM. Patient perceptions of quality of life with diabetes-related complications and treatments. Diabetes Care. 2007;30:2478-2483.

13. Dungan KM. The effect of diabetes on hospital readmissions. J Diabetes Sci Technol. 2012;6(5):1045-1052.

14. Menzin J, Korn JR, Cohen J, et al. Relationship between glycemic control and diabetes-related hospital costs in patients with type 1 or type 2 diabetes mellitus. Journal of Managed Care Pharmacy, 2010;16(4):264-275.

15. Bennett KJ, Probst JC, Vyavaharkar M, Glover SH. Lower rehospitalization rates among rural Medicare beneficiaries with diabetes. The Journal of Rural Health. $2012 ; 28: 227-234$. 
16. Jiang HJ, Stryer D, Friedman B, Andrews R. Multiple hospitalizations for patients with diabetes. Diabetes Care. 2003;26(5):1421-1426.

17. Maciejewski ML, Maynard C. Diabetes-related utilization and costs for inpatient and outpatient services in the Veterans administration. Diabetes Care. 2004;27(S2):B69B73.

18. Key Features of the Affordable Care Act by Year. The US Department of Health and Human Services website. http://www.hhs.gov/healthcare/facts/timeline/timelinetext.html. Published n.d. Accessed in February 2, 2014.

19. Health Information Management Systems Society (HIMSS). Electronic health record. Chicago, IL: The Health Information Management Systems Society; 2009.

20. US Department of Health and Human Services (US DHHS). HITECH act enforcement interim final rule. Washington D.C.: US DHHS; 2009.

21. Meaningful Use. The Centers for Disease Control and Prevention (CDC) website. http://www.cdc.gov/ehrmeaningfuluse/introduction.html. Published October 2012. Accessed October 19, 2012.

22. Meaningful Use Definition and Objectives. The Health IT.gov website. http://www.healthit.gov/providers-professionals/meaningful-use-definitionobjectives. Accessed January 1, 2014.

23. Jha AK, DesRoches CM, Kralovec PD, Joshi MS. A progress report on electronic health records in U.S. hospitals. Health Aff (Millwood). 2010;29(10):1951-1957.

24. Eligible Professional Meaningful Use Table of Contents Core and Menu Set Objectives Stage 1. The Centers for Medicare and Medicaid Services website. https://www.cms.gov/Regulations-and- 
Guidance/Legislation/EHRIncentivePrograms/downloads/EP-MU-TOC.pdf. Accessed January 1, 2014.

25. Meaningful Use. The Centers for Medicaid and Medicare Services (CMS) website. http://www.cms.gov/Regulations-andGuidance/Legislation/EHRIncentivePrograms/Meaningful_Use.html. Updated December 6, 2013. Accessed January 1, 2014.

26. Stage 2 Eligible Professional (EP) Meaningful Use Core and Menu Measures Table of Contents. The Centers for Medicare and Medicaid Services website. http://www.cms.gov/Regulations-andGuidance/Legislation/EHRIncentivePrograms/Downloads/Stage2_MeaningfulUseSpe cSheet_TableContents_EPs.pdf. Accessed January 1, 2014.

27. Kelley TF, Brandon DH, Docherty, SL. Electronic nursing documentation as a strategy to improve quality of patient care. J Nurs Scholarsh. 2011;43(2):154-162.

28. Hsiao C-J, Hing E. Use and characteristics of electronic health record systems among office-based physician practices: United States, 2001-2013. NCHS Data Brief, no 143. Hyattsville, MD: National Center for Health Statistics; 2014.

29. Dahm MF, Wadensten B. Nurses' experiences of and opinions about using standardised care plans in electronic health records - a questionnaire study. Journal of Clinical Nursing. 2008;17:2137-2145.

30. de Veer AJE, Francke AL. Attitudes of nursing staff towards electronic patient records: a questionnaire survey. Int J Nurs Stud. 2010;47(7):846-854.

31. Kutney-Lee A, Kelly D. The effect of hospital electronic health record adoption on nurse-assessed quality of care and patient safety. J Nurs Adm. 2011;41(11):466-472. 
32. Linder JA, Ma J, Bates DW, Middleton B, Stafford RS. Electronic health record use and the quality of ambulatory care in the U.S. Arch Intern Med. 2007;167(13):14001405.

33. McCormick D, Bor DH, Woolhandler S, Himmelstein DU. Giving office-based physicians electronic access to patients' prior imaging and lab results did not deter ordering of tests. Health Aff (Millwood). 2012;31(3):488-496.

34. Kerr EA. Assessing Quality of Care for Diabetes. Conference Final Report. (AHRQ Grant No. R13 HS01628). AHRQ Publication No. 08-0037-EF. Rockville, MD: Agency for Healthcare Research and Quality; 2008.

35. Lee PG, Cigolle CT, Blaum, CS. Quality improvement in the diagnosis and management of diabetes mellitus in older adults. Clinical Geriatrics, 2010;18(5):3844.

36. Fleming BB, Greenfield S, Engelgau MM, et al. The diabetes quality improvement project: moving science into health policy to gain an edge on the diabetes epidemic. Diabetes Care. 2001;24(10):1815-1820.

37. Performance Measurement Set for Adult Diabetes. The National Diabetes Quality Improvement Alliance website. http://www.nyqa.org/pdflib/NDQIA\%20Diabetes\%20DomainFinal2005Measures.pdf. Published January 2005. Accessed August 19, 2012.

38. The Healthcare Effectiveness Data and Information Set (HEDIS) 2013 Measures. The National Committee for Quality Assurance website. http://www.ncqa.org/Portals/0/HEDISQM/HEDIS2013/List_of_HEDIS_2013_Measu res_7.2.12.pdf. Published July 2012. Accessed September 19, 2012. 
39. Physician Consortium for Performance Improvement. Measures Development, Methodology, and Oversight Advisory Committee: Recommendations to PCPI Work Groups on Outcome Measures. Chicago: AMA; 2011.

40. Friedberg MW, Coltin KL, Safran DG, Dresser M, Zaslavsky AM, Schneider EC. Associations between structural capabilities of primary care practices and performance on selected quality measures. Ann Intern Med. 2009;151(7):456-463.

41. Kern LM, Barron Y, Dhopeshwarkar RV, Edwards A, Kaushal R, HITEC Investigators. Electronic health records and ambulatory quality of care. J Gen Intern Med. 2013;28(4):496-503.

42. Ryan AM, Bishop TF, Shih S, Casalino LP. Small physician practices in New York needed sustained help to realize gains in quality from use of electronic health records. Health Aff (Millwood). 2013;32(1):53-62.

43. Crosson JC, Ohman-Strickland P, Cohen DJ, Clark EC, Crabtree BF. Typical electronic health record use in primary care practices and the quality of diabetes care. Ann Fam Med. 2012;10(3):221-227.

44. Devoe JE, Gold R, McIntire P, Puro J, Chauvie S, Gallia CA. Electronic health records vs Medicaid claims: completeness of diabetes preventive care data in community health centers. Ann Fam Med. 2011;9(4):351-358.

45. Herrin J, da Graca B, Nicewander D, et al. The effectiveness of implementing an electronic health record on diabetes care and outcomes. Health Services Research. 2012;47(4):1522-1540.

46. Cebul RD, Love TE, Jain AK, Hebert CJ. Electronic health records and quality of diabetes care. N Engl J Med. 2011;365(9):825-833. 
47. Fleurant M, Kell R, Love J, et al. Massachusetts e-health project increased physicians' ability to use registries, and signals progress toward better care. Health Aff (Millwood). 2011;30(7):1256-1264.

48. Linder JA, Schnipper JL, Middleton B. Method of electronic health record documentation and quality of primary care. J Am Med Inform Assoc. 2012 2012;19(6):1019-1024.

49. Linmans JJ, Viechtbauer W, Koppenaal T, Spigt M, Knottnerus JA. Using electronic medical records analysis to investigate the effectiveness of lifestyle programs in realworld primary care is challenging: a case study in diabetes mellitus. J Clin Epidemiol. 2012;65(7):785-792.

50. Welch WP, Bazarko D, Ritten K, Burgess Y, Harmon R, Sandy LG. Electronic health records in four community physician practices: impact on quality and cost of care. $J$ Am Med Inform Assoc. 2007;14(3):320-328. 
Table

Characteristics of Studies Included in Integrative Literature Review about the Effects of Using Electronic Health Records on the Quality of Diabetes Care

\begin{tabular}{|c|c|c|c|c|c|c|c|c|c|c|}
\hline No. & $\begin{array}{l}\text { First } \\
\text { Author, } \\
\text { (Year), } \\
\text { Country }\end{array}$ & $\begin{array}{c}\text { Research } \\
\text { Questions/- } \\
\text { Specific } \\
\text { Aims/ } \\
\text { Hypotheses }\end{array}$ & Setting & Population & $\begin{array}{c}\text { Demograp } \\
\text { hic } \\
\text { Characteri } \\
\text { stics at } \\
\text { Baseline } \\
\end{array}$ & $\begin{array}{l}\text { Study } \\
\text { Design }\end{array}$ & $\begin{array}{c}\text { Assessment } \\
\text { for Quality } \\
\text { of Diabetes } \\
\text { Care }\end{array}$ & Duration & $\begin{array}{c}\text { Process } \\
\text { Measures }\end{array}$ & $\begin{array}{c}\text { Intermediate } \\
\text { Outcomes }\end{array}$ \\
\hline 1 & $\begin{array}{l}\text { Cebul et } \\
\text { al. } \\
\text { (2011), } \\
\text { US }\end{array}$ & $\begin{array}{l}\text { To examine } \\
\text { the } \\
\text { association } \\
\text { between EHR } \\
\text { implementati } \\
\text { on and } \\
\text { quality of } \\
\text { care for } \\
\text { patients } \\
\text { diagnosed } \\
\text { with diabetes. }\end{array}$ & $\begin{array}{l}7 \\
\text { primary } \\
\text { care } \\
\text { practices }\end{array}$ & $\begin{array}{l}27,207 \\
\text { patients: } \\
24,547 \text { were } \\
\text { in EHR } \\
\text { practices and } \\
2,660 \text { were in } \\
\text { paper-based } \\
\text { practices }\end{array}$ & $\begin{array}{l}\text { Mean age: } \\
57.8 ; \\
52.4 \% \\
\text { females; } \\
47.9 \% \text { no- } \\
\text { white } \\
\text { race; and } \\
35.1 \% \\
\text { covered } \\
\text { by } \\
\text { Medicare. }\end{array}$ & $\begin{array}{l}\text { Longitudi } \\
\text { nal study }\end{array}$ & $\begin{array}{l}\text { Using nine } \\
\text { quality } \\
\text { standards } \\
\text { for diabetes } \\
\text { approved by } \\
\text { Better } \\
\text { Health's } \\
\text { Clinical } \\
\text { Advisory } \\
\text { Committee. }\end{array}$ & $\begin{array}{l}\text { Three } \\
\text { years }\end{array}$ & $\begin{array}{l}\text { HbA1c } \\
\text { measuremen } \\
\text { t, kidney } \\
\text { management } \\
\text { (urinary } \\
\text { microalbumi } \\
\text { n), eye } \\
\text { examination, } \\
\text { pneumococc } \\
\text { al } \\
\text { vaccination } \\
\text { were better } \\
\text { performed } \\
\text { after EHR } \\
\text { implementat } \\
\text { ion. }\end{array}$ & $\begin{array}{l}\text { Achievemen } \\
\text { ts of HbA1c } \\
<8 \%, \mathrm{BP} \\
<140 / 80 \mathrm{~mm} \\
\mathrm{Hg}, \mathrm{LDL}-\mathrm{C} \\
<100 \mathrm{mg} / \mathrm{dL} \\
\text { or use of } \\
\text { Statin drug, } \\
\text { BMI <30, } \\
\text { and non- } \\
\text { smoker } \\
\text { status were } \\
\text { better after } \\
\text { EHR } \\
\text { implementat } \\
\text { ion. }\end{array}$ \\
\hline 2 & $\begin{array}{l}\text { Crosson } \\
\text { et al. } \\
\text { (2012), } \\
\text { US }\end{array}$ & $\begin{array}{l}\text { To compare } \\
\text { the outcomes } \\
\text { of chronic } \\
\text { illness care } \\
\text { associated } \\
\text { with the use } \\
\text { of EHR } \\
\text { records and } \\
\text { paper records. }\end{array}$ & $\begin{array}{l}42 \\
\text { primary } \\
\text { care } \\
\text { practices } \\
: 16 \text { used } \\
\text { EHRs } \\
\text { and } 26 \\
\text { used } \\
\text { paper } \\
\text { records. }\end{array}$ & $\begin{array}{l}763 \text { adult } \\
\text { patients } \\
\text { diagnosed } \\
\text { with diabetes }\end{array}$ & $\begin{array}{l}60.2 \pm \\
14.6 \\
\text { years; } \\
53 \% \\
\text { females, }\end{array}$ & $\begin{array}{l}\text { Longitudi } \\
\text { nal } \\
\text { observatio } \\
\text { nal study }\end{array}$ & $\begin{array}{l}\text { Using } \\
\text { guidelines } \\
\text { from the } \\
\text { clinical } \\
\text { practice } \\
\text { guidelines } \\
\text { of the } \\
\text { American } \\
\text { Diabetes } \\
\text { Association. }\end{array}$ & $\begin{array}{l}\text { Three } \\
\text { years: } \\
\text { Baseline } \\
\text { and at } 1 \\
\text { and } 2 \text { year } \\
\text { follow up. }\end{array}$ & $\begin{array}{l}\text { No } \\
\text { difference } \\
\text { between } \\
\text { EHR and } \\
\text { paper-based } \\
\text { practices in } \\
\text { meeting the } \\
\text { recommende } \\
\text { d process of } \\
\text { diabetes } \\
\text { care. }\end{array}$ & $\begin{array}{l}\text { No } \\
\text { difference } \\
\text { between } \\
\text { EHR and } \\
\text { paper base } \\
\text { practices in } \\
\text { achieving } \\
\text { the } \\
\text { recommende } \\
\text { d outcomes } \\
\text { (HbA1c < } \\
7 \%, \text { LDL-C } \\
<100 \\
\text { mg/dL, BP } \\
<130 / 85 \\
\text { mmHg) }\end{array}$ \\
\hline
\end{tabular}


Table

Characteristics of Studies Included in Integrative Literature Review about the Effects of Using Electronic Health Records on the Quality of Diabetes Care

\begin{tabular}{|c|c|c|c|c|c|c|c|c|c|c|}
\hline No. & $\begin{array}{l}\text { First } \\
\text { Author, } \\
\text { (Year), } \\
\text { Country }\end{array}$ & $\begin{array}{c}\text { Research } \\
\text { Questions/- } \\
\text { Specific } \\
\text { Aims/ } \\
\text { Hypotheses }\end{array}$ & Setting & Population & $\begin{array}{c}\text { Demograp } \\
\text { hic } \\
\text { Characteri } \\
\text { stics at } \\
\text { Baseline }\end{array}$ & $\begin{array}{l}\text { Study } \\
\text { Design }\end{array}$ & $\begin{array}{c}\text { Assessment } \\
\text { for Quality } \\
\text { of Diabetes } \\
\text { Care }\end{array}$ & Duration & $\begin{array}{c}\text { Process } \\
\text { Measures }\end{array}$ & $\begin{array}{c}\text { Intermediate } \\
\text { Outcomes }\end{array}$ \\
\hline 3 & $\begin{array}{l}\text { DeVoe } \\
\text { et al. } \\
(2011) \text {, } \\
\text { US }\end{array}$ & $\begin{array}{l}\text { To examine } \\
\text { whether EHR } \\
\text { data related to } \\
\text { the receipt of } \\
\text { preventive } \\
\text { care services } \\
\text { among } \\
\text { patients } \\
\text { diagnosed } \\
\text { with diabetes } \\
\text { in a CHC } \\
\text { population } \\
\text { were more } \\
\text { accurate than } \\
\text { their data in } \\
\text { the Medicaid } \\
\text { claims. }\end{array}$ & $\begin{array}{l}\text { A } \\
\text { network } \\
\text { of } \\
\text { Commun } \\
\text { ity } \\
\text { Health } \\
\text { Centers } \\
\text { (CHCs) } \\
\text { with } \\
\text { linked } \\
\text { EHR } \\
\text { data. }\end{array}$ & $\begin{array}{l}2,103 \text { adult } \\
\text { patients } \\
\text { diagnosed } \\
\text { with diabetes } \\
\text { and have an } \\
\text { Oregon } \\
\text { Medicaid } \\
\text { identification } \\
\text { (ID). }\end{array}$ & $\begin{array}{l}78.5 \% \\
\text { aged 19- } \\
64 \text { years; } \\
62.1 \% \\
\text { females; } \\
60.7 \% \\
\text { whites; } \\
63.9 \% \\
\text { covered } \\
\text { by } \\
\text { Medicaid. }\end{array}$ & $\begin{array}{l}\text { Retrospect } \\
\text { ive } \\
\text { longitudin } \\
\text { al study }\end{array}$ & $\begin{array}{l}\text { Using } \\
\text { guidelines } \\
\text { from the } \\
\text { clinical } \\
\text { practice } \\
\text { guidelines } \\
\text { of the } \\
\text { American } \\
\text { Diabetes } \\
\text { Association } \\
\text { and the } \\
\text { Centers for } \\
\text { Disease } \\
\text { Control and } \\
\text { Prevention. }\end{array}$ & $\begin{array}{l}\text { Three } \\
\text { years }\end{array}$ & $\begin{array}{l}\text { Percentages } \\
\text { of patients } \\
\text { who had } \\
\text { influenza } \\
\text { vaccination, } \\
\text { microalbumi } \\
\text { n screen, } \\
\text { LDL screen, } \\
\text { and HbA1c } \\
\text { test } \\
\text { documented } \\
\text { in EHRs } \\
\text { were } \\
\text { consistently } \\
\text { higher than } \\
\text { in Medicaid } \\
\text { claims. }\end{array}$ & - \\
\hline 4 & $\begin{array}{l}\text { Fleurant } \\
\text { et al. } \\
\text { (2011), } \\
\text { US }\end{array}$ & $\begin{array}{l}\text { To evaluate } \\
\text { the } \\
\text { implementati } \\
\text { on of EHRs } \\
\text { using pre- } \\
\text { post surveys } \\
\text { to measure } \\
\text { physicians' } \\
\text { ability to } \\
\text { generate } \\
\text { registries. }\end{array}$ & $\begin{array}{l}\text { Primary } \\
\text { care and } \\
\text { specialty } \\
\text { practices } \\
\text { in the } \\
\text { Massach } \\
\text { usetts } \\
\text { communi } \\
\text { ties of } \\
\text { Brochton } \\
\text { Newbury } \\
\text { port, and } \\
\text { North } \\
\text { Adams. }\end{array}$ & $\begin{array}{l}163 \\
\text { physicians } \\
\text { from } 134 \\
\text { practices. }\end{array}$ & $\begin{array}{l}49 \pm 9.9 \\
\text { years; } \\
75 \% \\
\text { males, } \\
80 \% \\
\text { whites. }\end{array}$ & $\begin{array}{l}\text { Pre-post } \\
\text { interventio } \\
\text { n surveys }\end{array}$ & $\begin{array}{l}\text { Using the } \\
\text { Massachuset } \\
\text { ts Survey of } \\
\text { Physicians } \\
\text { and } \\
\text { Computer } \\
\text { Technology. }\end{array}$ & $\begin{array}{l}\text { Pre-survey } \\
\text { in } 2005 \\
\text { and post- } \\
\text { survey in } \\
2009\end{array}$ & $\begin{array}{l}\text { Proportion } \\
\text { of } \\
\text { physicians- } \\
\text { who were } \\
\text { categorized } \\
\text { as high EHR } \\
\text { users - in } \\
\text { using } \\
\text { registry } \\
\text { functions to } \\
\text { remind } \\
\text { patients } \\
\text { about } \\
\text { overdue } \\
\text { testing was }\end{array}$ & - \\
\hline
\end{tabular}


Table

Characteristics of Studies Included in Integrative Literature Review about the Effects of Using Electronic Health Records on the Quality of Diabetes Care

\begin{tabular}{|c|c|c|c|c|c|c|c|c|c|c|}
\hline No. & $\begin{array}{l}\text { First } \\
\text { Author, } \\
\text { (Year), } \\
\text { Country }\end{array}$ & $\begin{array}{c}\text { Research } \\
\text { Questions/- } \\
\text { Specific } \\
\text { Aims/ } \\
\text { Hypotheses }\end{array}$ & Setting & Population & $\begin{array}{c}\text { Demograp } \\
\text { hic } \\
\text { Characteri } \\
\text { stics at } \\
\text { Baseline }\end{array}$ & $\begin{array}{l}\text { Study } \\
\text { Design }\end{array}$ & $\begin{array}{c}\text { Assessment } \\
\text { for Quality } \\
\text { of Diabetes } \\
\text { Care }\end{array}$ & Duration & $\begin{array}{c}\text { Process } \\
\text { Measures }\end{array}$ & $\begin{array}{c}\text { Intermediate } \\
\text { Outcomes }\end{array}$ \\
\hline & & & & & & & & & $\begin{array}{l}\text { higher than } \\
\text { those who } \\
\text { were low } \\
\text { EHR users } \\
\text { for patient } \\
\text { diagnosed } \\
\text { with } \\
\text { diabetes. }\end{array}$ & \\
\hline 5 & $\begin{array}{l}\text { Friedber } \\
\text { g et al. } \\
\text { (2009), } \\
\text { US }\end{array}$ & $\begin{array}{l}\text { To examine } \\
\text { associations } \\
\text { between } \\
\text { structural } \\
\text { capabilities of } \\
\text { primary care } \\
\text { practices and } \\
\text { performance } \\
\text { on quality } \\
\text { measures for } \\
\text { screening, } \\
\text { diabetes, } \\
\text { depression, } \\
\text { and } \\
\text { avoidance of } \\
\text { overuse. }\end{array}$ & $\begin{array}{l}\text { Primary } \\
\text { care } \\
\text { practices } \\
\text {. }\end{array}$ & $\begin{array}{l}305 \text { primary } \\
\text { care } \\
\text { practices. }\end{array}$ & $\begin{array}{l}33 \% \text { used } \\
\text { frequently } \\
\text { multifunct } \\
\text { ion EHRs. }\end{array}$ & $\begin{array}{l}\text { Cross- } \\
\text { sectional } \\
\text { analysis. }\end{array}$ & $\begin{array}{l}\text { Using the } \\
\text { Healthcare } \\
\text { Effectivenes } \\
\text { s Data and } \\
\text { Information } \\
\text { Set } \\
\text { (HEDIS) } \\
\text { measures. }\end{array}$ & 6 months & $\begin{array}{l}\text { Eye } \\
\text { examination } \\
\text { s and } \\
\text { nephropathy } \\
\text { monitoring } \\
\text { were done } \\
\text { better after } \\
\text { EHR } \\
\text { implementat } \\
\text { ion. }\end{array}$ & - \\
\hline 6 & $\begin{array}{l}\text { Herrin } \\
\text { et al. } \\
\text { (2012), } \\
\text { US }\end{array}$ & $\begin{array}{l}\text { To examine } \\
\text { the impact of } \\
\text { EHR } \\
\text { implementati } \\
\text { on on primary } \\
\text { care diabetes } \\
\text { care. }\end{array}$ & $\begin{array}{l}\text { HealthTe } \\
\text { xas } \\
\text { Provider } \\
\text { Network } \\
\text { (ambulat } \\
\text { ory care) }\end{array}$ & $\begin{array}{l}14,051 \\
\text { patients } \\
\text { diagnosed } \\
\text { with diabetes } \\
\text { registered in } \\
34 \text { primary } \\
\text { care practices }\end{array}$ & $\begin{array}{l}58.1 \% \\
\text { aged } 41- \\
60 \text { years; } \\
50.5 \% \\
\text { females. }\end{array}$ & $\begin{array}{l}\text { Longitudi } \\
\text { nal study }\end{array}$ & $\begin{array}{l}\text { Using the } \\
\text { AMA } \\
\text { Physician } \\
\text { Consortium } \\
\text { Adult } \\
\text { Diabetes } \\
\text { Measure set. }\end{array}$ & Five years & $\begin{array}{l}\text { EHR use } \\
\text { improved } \\
\text { the receipt } \\
\text { of BP } \\
\text { control, } \\
\text { microalbumi } \\
\text { n screening, } \\
\text { eye and foot }\end{array}$ & $\begin{array}{l}\text { EHR use } \\
\text { achieved the } \\
\text { recommende } \\
\text { d BP levels. } \\
\text { However, } \\
\text { achieving } \\
\text { the } \\
\text { recommende }\end{array}$ \\
\hline
\end{tabular}


Table

Characteristics of Studies Included in Integrative Literature Review about the Effects of Using Electronic Health Records on the Quality of Diabetes Care

\begin{tabular}{|c|c|c|c|c|c|c|c|c|c|c|}
\hline No. & $\begin{array}{l}\text { First } \\
\text { Author, } \\
\text { (Year), } \\
\text { Country }\end{array}$ & $\begin{array}{c}\text { Research } \\
\text { Questions/- } \\
\text { Specific } \\
\text { Aims/ } \\
\text { Hypotheses }\end{array}$ & Setting & Population & $\begin{array}{c}\text { Demograp } \\
\text { hic } \\
\text { Characteri } \\
\text { stics at } \\
\text { Baseline }\end{array}$ & $\begin{array}{l}\text { Study } \\
\text { Design }\end{array}$ & $\begin{array}{c}\text { Assessment } \\
\text { for Quality } \\
\text { of Diabetes } \\
\text { Care }\end{array}$ & Duration & $\begin{array}{c}\text { Process } \\
\text { Measures }\end{array}$ & $\begin{array}{c}\text { Intermediate } \\
\text { Outcomes }\end{array}$ \\
\hline & & & & & & & & & $\begin{array}{l}\text { examination } \\
\text { s, influenza } \\
\text { vaccine, } \\
\text { aspirin use, } \\
\text { and smoking } \\
\text { assessment. } \\
\text { However, } \\
\text { EHR use } \\
\text { decreased } \\
\text { the receipt } \\
\text { of HbA1c } \\
\text { test, lipid } \\
\text { control, and } \\
\text { urinanalysis. }\end{array}$ & $\begin{array}{l}\text { d HbA1c } \\
\text { level and } \\
\text { LDL } \\
\text { worsened } \\
\text { after the use } \\
\text { of EHR. }\end{array}$ \\
\hline 7 & $\begin{array}{l}\text { Kern et } \\
\text { al. } \\
(2012) \text {, } \\
\text { US }\end{array}$ & $\begin{array}{l}\text { To examine } \\
\text { the effect of } \\
\text { EHRs on } \\
\text { ambulatory } \\
\text { quality in a } \\
\text { community- } \\
\text { based setting }\end{array}$ & $\begin{array}{l}\text { Primary } \\
\text { care } \\
\text { physicia } \\
\text { ns }\end{array}$ & $\begin{array}{l}74,618 \\
\text { patients who } \\
\text { had visits to } \\
466 \\
\text { physicians. }\end{array}$ & $\begin{array}{l}52 \pm 10 \\
\text { years; } \\
68 \% \\
\text { males. }\end{array}$ & $\begin{array}{l}\text { Cross- } \\
\text { sectional } \\
\text { study }\end{array}$ & $\begin{array}{l}\text { Using the } \\
\text { Healthcare } \\
\text { Effectivenes } \\
\text { s Data and } \\
\text { Information } \\
\text { Set } \\
\text { (HEDIS) } \\
\text { measures. }\end{array}$ & - & $\begin{array}{l}\text { EHR use } \\
\text { was } \\
\text { associated } \\
\text { with } \\
\text { significantly } \\
\text { better } \\
\text { performance } \\
\text { than paper } \\
\text { for HbA1c } \\
\text { testing. }\end{array}$ & - \\
\hline 8 & $\begin{array}{l}\text { Linder } \\
\text { et al. } \\
\text { (2012), } \\
\text { US }\end{array}$ & $\begin{array}{l}\text { To examine } \\
\text { whether } \\
\text { primary care } \\
\text { physicians } \\
\text { who more } \\
\text { intensively } \\
\text { interact with } \\
\text { the EHR }\end{array}$ & $\begin{array}{l}\text { A } \\
\text { network } \\
\text { of } \\
\text { primary } \\
\text { care } \\
\text { clinics }\end{array}$ & $\begin{array}{l}188,554 \text { visit } \\
\text { notes from } 10 \\
\text { primary care } \\
\text { practices with } \\
235 \text { primary } \\
\text { care } \\
\text { physicians }\end{array}$ & $\begin{array}{l}\text { An } \\
\text { average of } \\
805 \text { notes } \\
\text { per } \\
\text { physician, } \\
9 \% \\
\text { physicians } \\
\text { dictated }\end{array}$ & $\begin{array}{l}\text { Cross- } \\
\text { sectional } \\
\text { analysis }\end{array}$ & $\begin{array}{l}\text { Using the } 15 \\
\text { EHR-based } \\
\text { coronary } \\
\text { artery } \\
\text { disease and } \\
\text { diabetes } \\
\text { measures. }\end{array}$ & $\begin{array}{l}9 \text { months } \\
\text { for each } \\
\text { practice. }\end{array}$ & $\begin{array}{l}\text { Quality of } \\
\text { diabetic eye } \\
\text { exam } \\
\text { appeared } \\
\text { worse for } \\
\text { physicians } \\
\text { who used } \\
\text { dictation. }\end{array}$ & - \\
\hline
\end{tabular}


Table

Characteristics of Studies Included in Integrative Literature Review about the Effects of Using Electronic Health Records on the Quality of Diabetes Care

\begin{tabular}{|c|c|c|c|c|c|c|c|c|c|c|}
\hline No. & $\begin{array}{c}\text { First } \\
\text { Author, } \\
\text { (Year), } \\
\text { Country }\end{array}$ & $\begin{array}{c}\text { Research } \\
\text { Questions/- } \\
\text { Specific } \\
\text { Aims/ } \\
\text { Hypotheses }\end{array}$ & Setting & Population & $\begin{array}{c}\text { Demograp } \\
\text { hic } \\
\text { Characteri } \\
\text { stics at } \\
\text { Baseline }\end{array}$ & $\begin{array}{l}\text { Study } \\
\text { Design }\end{array}$ & $\begin{array}{c}\text { Assessment } \\
\text { for Quality } \\
\text { of Diabetes } \\
\text { Care }\end{array}$ & Duration & $\begin{array}{l}\text { Process } \\
\text { Measures }\end{array}$ & $\begin{array}{c}\text { Intermediate } \\
\text { Outcomes }\end{array}$ \\
\hline & & $\begin{array}{l}\text { through their } \\
\text { documentatio } \\
\text { n style deliver } \\
\text { better quality } \\
\text { of care by } \\
\text { comparing } \\
\text { quality } \\
\text { between } \\
\text { physicians } \\
\text { who } \\
\text { predominantl } \\
\text { y dictated, } \\
\text { used } \\
\text { structured } \\
\text { documentatio } \\
\text { n, or typed } \\
\text { free text } \\
\text { notes. }\end{array}$ & & & $\begin{array}{l}\text { their notes } \\
\text { (attending } \\
\text { physicians } \\
\text {, older, } \\
\text { and had } \\
\text { more } \\
\text { visits), } \\
29 \% \text { used } \\
\text { structured } \\
\text { document } \\
\text { ation, 62\% } \\
\text { used free } \\
\text { text notes. }\end{array}$ & & & & $\begin{array}{l}\text { Quality of } \\
\text { blood } \\
\text { pressure } \\
\text { documentati } \\
\text { on and } \\
\text { diabetic foot } \\
\text { exam were } \\
\text { better for } \\
\text { physicians } \\
\text { using } \\
\text { structured } \\
\text { documentati } \\
\text { on. }\end{array}$ & \\
\hline 9 & $\begin{array}{l}\text { Linman } \\
\text { s et al. } \\
(2012) \text {, } \\
\text { The } \\
\text { Netherl } \\
\text { ands }\end{array}$ & $\begin{array}{l}\text { To examine } \\
\text { the effects of } \\
\text { the provided } \\
\text { care on the } \\
\text { course of } \\
\text { weight and } \\
\text { HbA1c. }\end{array}$ & $\begin{array}{l}\text { Corporat } \\
\text { ion } \\
\text { consistin } \\
\mathrm{g} \text { of } 9 \\
\text { primary } \\
\text { health } \\
\text { care } \\
\text { centers }\end{array}$ & $\begin{array}{l}2,549 \text { patients } \\
\text { with type } 2 \\
\text { diabetes } \\
\text { mellitus. }\end{array}$ & $\begin{array}{l}68.2 \pm \\
12.4 \\
\text { years; } \\
51.9 \% \\
\text { females. }\end{array}$ & $\begin{array}{l}\text { Retrospect } \\
\text { ive } \\
\text { longitudin } \\
\text { al analysis }\end{array}$ & $\begin{array}{l}\text { Using } \\
\text { diabetes } \\
\text { management } \\
\text { program. }\end{array}$ & $\begin{array}{l}\text { Two years } \\
\text { and six } \\
\text { months }\end{array}$ & $\begin{array}{l}\text { No } \\
\text { significant } \\
\text { changes in } \\
\text { the average } \\
\text { of HbAlc } \\
\text { over time. } \\
\text { Only } \\
\text { participants } \\
\text { who } \\
\text { improved } \\
\text { their } \\
\text { physical } \\
\text { activity level }\end{array}$ & - \\
\hline
\end{tabular}


Table

Characteristics of Studies Included in Integrative Literature Review about the Effects of Using Electronic Health Records on the Quality of Diabetes Care

\begin{tabular}{|c|c|c|c|c|c|c|c|c|c|c|}
\hline No. & $\begin{array}{c}\text { First } \\
\text { Author, } \\
\text { (Year), } \\
\text { Country }\end{array}$ & $\begin{array}{c}\text { Research } \\
\text { Questions/- } \\
\text { Specific } \\
\text { Aims/ } \\
\text { Hypotheses }\end{array}$ & Setting & Population & $\begin{array}{c}\text { Demograp } \\
\text { hic } \\
\text { Characteri } \\
\text { stics at } \\
\text { Baseline }\end{array}$ & $\begin{array}{l}\text { Study } \\
\text { Design }\end{array}$ & $\begin{array}{c}\text { Assessment } \\
\text { for Quality } \\
\text { of Diabetes } \\
\text { Care }\end{array}$ & Duration & $\begin{array}{l}\text { Process } \\
\text { Measures }\end{array}$ & $\begin{array}{c}\text { Intermediate } \\
\text { Outcomes }\end{array}$ \\
\hline & & & & & & & & & $\begin{array}{l}\text { had lower } \\
\text { HbAlc. }\end{array}$ & \\
\hline 10 & $\begin{array}{l}\text { Ryan et } \\
\text { al. } \\
(2013), \\
\text { US }\end{array}$ & $\begin{array}{l}\text { To } \\
\text { investigate } \\
\text { the impact of } \\
\text { EHR } \\
\text { adoption on } \\
\text { quality of } \\
\text { care in small } \\
\text { primary care } \\
\text { practices. }\end{array}$ & $\begin{array}{l}\text { Small } \\
\text { primary } \\
\text { care } \\
\text { practices } \\
\text { for } \\
\text { underser } \\
\text { ved } \\
\text { populatio } \\
\text { n in New } \\
\text { York. }\end{array}$ & $\begin{array}{l}3,589 \\
\text { observations, } \\
516 \text { total } \\
\text { physicians, } \\
\text { and } 258 \text { PCIP } \\
\text { physicians. }\end{array}$ & $\begin{array}{l}\text { The } \\
\text { location of } \\
\text { practice, } \\
43.7 \% \text { in } \\
\text { New York } \\
\text { City. }\end{array}$ & $\begin{array}{l}\text { Retrospect } \\
\text { ive } \\
\text { longitudin } \\
\text { al study }\end{array}$ & $\begin{array}{l}\text { Using the } \\
\text { Healthcare } \\
\text { Effectivenes } \\
\text { s Data and } \\
\text { Information } \\
\text { Set } \\
\text { (HEDIS) } \\
\text { measures. }\end{array}$ & $\begin{array}{l}\text { Three } \\
\text { years: } \\
\text { before } \\
\text { EHR and } \\
\text { up to two } \\
\text { years after } \\
\text { EHR } \\
\text { implement } \\
\text { ation. }\end{array}$ & $\begin{array}{l}\text { EHR } \\
\text { through } \\
\text { PCIP was } \\
\text { associated } \\
\text { with } \\
\text { improvemen } \\
\text { ts in quality } \\
\text { of care on } \\
\text { retinal } \\
\text { exams and } \\
\text { urine testing } \\
\text { for patients } \\
\text { with } \\
\text { diabetes. }\end{array}$ & - \\
\hline 11 & $\begin{array}{l}\text { Welch } \\
\text { et al. } \\
\text { (2007), } \\
\text { US }\end{array}$ & $\begin{array}{l}\text { To examine } \\
\text { the impact of } \\
\text { implementing } \\
\text { EHRs in } \\
\text { community- } \\
\text { based private } \\
\text { practices. }\end{array}$ & $\begin{array}{l}\text { Four } \\
\text { communi } \\
\text { ty-based } \\
\text { private } \\
\text { practices } \\
\text {. }\end{array}$ & $\begin{array}{l}56 \text { practices: } \\
4 \text { study } \\
\text { practices and } \\
52 \text { control } \\
\text { practices. }\end{array}$ & - & $\begin{array}{l}\text { Retrospect } \\
\text { ive before- } \\
\text { after- } \\
\text { study- } \\
\text { control. }\end{array}$ & $\begin{array}{l}\text { Using EBM } \\
\text { Connect } \\
\text { software. }\end{array}$ & One year & $\begin{array}{l}\text { The EHR } \\
\text { impact was } \\
\text { insignificant } \\
\text { for diabetes. }\end{array}$ & - \\
\hline
\end{tabular}




\section{CHAPTER FIVE}

\section{Manuscript Three}

\section{"The Association of Electronic Health Record Use on Quality of Care for Patients Diagnosed with Type 2 Diabetes"}

(To be submitted to the Journal of Nursing Care Quality)

1. Author names and credentials: Rini Rachmawaty, MN, RN (Indonesia); Marianne Baernholdt, PhD, MPH, RN; Guofen Yan, PhD; Susan Huerta, PhD, RN; Myra Clark, PhD, RN, FNP-C.

2. Author affiliations: School of Nursing, University of Virginia, Charlottesville and Faculty of Medicine, Hasanuddin University, Makassar, Indonesia (Ms. Rachmawaty); School of Nursing and Department of Public Health Sciences, University of Virginia, Charlottesville (Dr. Baernholdt); School of Medicine, University of Virginia, Charlottesville (Dr. Yan); Froedtert hospital (Dr. Huerta); and School of Nursing, University of Virginia, Charlottesville (Dr. Clark).

3. Corresponding author: Rini Rachmawaty, MN, RN (Indonesia), School of Nursing, University of Virginia, McLeod Hall, Room \#5031 (Doctoral Lounge), 202 Jeanette Lancaster Way, Charlottesville, VA 22903 (r7bz@virginia.edu).

4. Funding information: The first author received a Fulbright Presidential Scholarship (2010-2013) to study for a PhD in nursing at the University of Virginia. This research is conducted as part of her $\mathrm{PhD}$ program. 


\begin{abstract}
Findings on the use of electronic health records (EHRs) and its influence on quality of diabetes care are mixed. The association of EHR use on quality of care for the same patients diagnosed with type 2 diabetes who visited outpatient services at the same health system is unknown. Using secondary data analysis, this study compared process and intermediate outcome measures for the same patient pre-EHR, one year post-EHR, and two years post-EHR. This study found that in process measures, the frequency and proportion of patients whose BP measurements were documented increased significantly from pre-EHR to one year and two years post-EHR. However, frequency of HbA1c and lipid profile tests documented and proportion of patients having HbA1c tests documented, declined significantly from pre-EHR to two years post-EHR. In intermediate outcome measures, the proportion of patients achieving the recommended level of total cholesterol was significantly higher in two years post-EHR than pre-EHR. In contrast, the proportion of patients achieving the recommended level of HbA1c was significantly lower in one year and two years post-EHR than pre-EHR. Likewise, the proportion of patients achieving the recommended level of SBP was lower one year postEHR than pre-EHR. No significant differences in proportions of patients were identified in DBP and other lipid profile pre- and post-EHR. Furthermore, the study results showed that mean levels of $\mathrm{HbA1c}, \mathrm{BP}$, and HDL-C significantly increased over time. Changes in the three variables were affected by age, sex, race, and type of health insurance (i.e., Medicaid, uninsured, other). Results from this study confirm that EHR use is associated with better clinical documentation for vital signs (i.e., BP). Additionally, the findings demonstrate that EHRs will promote changes in clinical staff and patient behavior due to
\end{abstract}


better data at the point of care. Further studies to examine the effect of other comprehensive EHR components (e.g., clinical decision support system) on quality of diabetes care are recommended. Suggestions for hospital administrators to consider EHR adoption and to add nursing care elements to their EHRs are also offered by this study.

Keywords: electronic health records, quality of care, type 2 diabetes 


\section{INTRODUCTION}

In 2011, 8.3\% of the United States (US) population or 25.8 million people had diabetes. ${ }^{1-2}$ Diabetes is a serious chronic disease, and if it is not treated and controlled properly, it can cause long-term microvascular and macrovascular complications, including heart disease, stroke, chronic kidney disease, neuropathy, and retinopathy. ${ }^{2}$ It is also the leading cause of lower limb amputation. ${ }^{2}$ In 2007, diabetes was determined to be the seventh leading cause of death in the US based on 71,382 death certificates. ${ }^{1}$ The economic cost of diabetes in the US is projected to increase from $\$ 245$ billion in 2012 to almost $\$ 500$ billion in $2020 .^{3-4}$

With regard to all the consequences and economic costs resulting from unmanaged diabetes, in 2001 the Institute of Medicine (IOM) recommended a variety of strategies to enhance public policy concerning health care quality improvement, including attention to care for chronic diseases. Under the American Recovery and Reinvestment Act of 2009 (ARRA), one strategy to manage patients with chronic diseases is to use electronic health records (EHRs) ${ }^{5-7}$ In accordance with the 2009 Health Information Technology Economic and Clinical Health (HITECH) Act, all hospitals in the US are expected to adopt EHRs and to be EHR meaningful users by the end of $2014{ }^{8}$

"Meaningful use" (MU) is defined as the use of certified EHRs by eligible professionals, eligible hospitals, and critical access hospitals, in a meaningful manner, as governed by the Centers for Medicare \& Medicaid Services (CMS) Incentive Programs. ${ }^{9}$ There are three stages of MU: Stage 1 (2011-2012) focuses on data capture and sharing, Stage 2 (2014) focuses on advanced clinical processes, and Stage 3 (2016) focuses on improved outcomes. ${ }^{9}$ In Stage 1, there are 24 MU objectives for eligible professionals, 
including using computerized physician order entry for medication orders, recording all patient demographics, recording and charting changes in vital signs, and providing clinical summaries for patients for each office visit. ${ }^{9}$ To qualify for an incentive payment, 19 of these 24 objectives must be met. ${ }^{9}$ All providers must meet the Stage 1 requirements before moving to Stage 2. In Stage 2, there are $23 \mathrm{MU}$ objectives for eligible professionals and 20 of these 23 objectives must be met in order to receive an incentive payment. ${ }^{9}$ In Stage 2, the additional objective for eligible professionals is to use secure electronic messaging to communicate with patients on relevant health information. Currently, MU objectives for Stages 1 and 2 are only available in the government website. ${ }^{9}$

Studies examining the effectiveness of EHR implementation in improving the quality of diabetes care have overwhelmingly positive results. ${ }^{10-20}$ In 11 studies, quality of diabetes care was assessed using process and intermediate outcome measures. Process measures are defined as measures that reflect diabetes care guidelines, including number of glycosylated hemoglobin (HbA1c) tests, blood pressure (BP) control, and lipid profile measurements received by each patient per year. ${ }^{21-22}$ Furthermore, intermediate outcome measures are defined as measures that aim to achieve specific thresholds of clinical care, including $\mathrm{HbA} 1 \mathrm{c}$ level of $\leq 7 \%$, BP level of $<140 / 80 \mathrm{mmHg}$, total cholesterol level of $<170 \mathrm{mg} / \mathrm{dL}$, high density lipoprotein-cholesterol (HDL-C) level of $>45 \mathrm{mg} / \mathrm{dL}$, low density lipoprotein-cholesterol (LDL-C) level of $<100 \mathrm{mg} / \mathrm{dL}$, and triglycerides level of $<150 \mathrm{mg} / \mathrm{dL} .^{22-24}$

Of these 11 studies, six demonstrate positive improvements in the process of diabetes care only after EHR implementation. ${ }^{11-13,15-17}$ Of the six studies, significant 
improvements in $\mathrm{HbA} 1 \mathrm{c}$ measurements are found in three studies, ${ }^{10-13}$ eye examinations in three studies, ${ }^{10,13-14}$ foot examinations in two studies, ${ }^{14,16} \mathrm{BP}$ controls in two studies, ${ }^{14,16}$ and nephropathy screening in five studies. ${ }^{10-11,13-14,17}$ Only two studies argue that EHR use can improve both the process of diabetes care and the recommended intermediate outcomes. ${ }^{10,14}$ Regarding intermediate outcomes, only BP is found to have significantly improved in both studies after EHR implementation $(<140 / 80 \mathrm{mmHg})$. Meanwhile, three studies did not show significant improvement either in the process of diabetes care or in intermediate outcomes. ${ }^{18-20}$

Although 11 studies have been conducted to determine the effect of EHR implementation on quality of diabetes care, no studies were conducted within the same health system with the same EHR vendor and neither did they measure quality of diabetes care from the same patients over time. It is contended that using these methods may reduce the study variance and suggest more compelling results than reported in previous studies.

Moreover, the findings of the review based on qualitative studies examining nurses' and other EHR users' perceptions regarding the effect of using EHRs on patient care quality were mixed. Twelve studies reported that some participants included in their studies (nurses, nurse practitioners, physicians, administrative/licensed staff, and ambulatory care network/information systems/practice/vendor leadership) positively perceived the use of EHRs on patient care quality. ${ }^{25-36}$ However, seven studies stated that some other nurses, physicians, and administrative/licensed staff included in their studies negatively perceived the impact of EHR use on patient care quality. ${ }^{27-29,32-34,32,36}$ The mix of these qualitative findings was used as the foundation for this study to clarify whether 
or not the EHR system can be employed to improve the quality of patient care, particularly diabetes care.

In 2013, 78\% of office-based physicians used one of two types of EHR system, either a basic or a comprehensive EHR system. ${ }^{37}$ Although there was a significant improvement in EHR adoption by office-based physicians from 18\% in 2001 to $78 \%$ in 2013, there are hospitals that still have not adopted the EHR system yet (22\%). Hence, the purpose of this study was to investigate the association of EHR implementation on quality of care (process and intermediate outcomes) for the same adult patients diagnosed with type 2 diabetes who visited outpatient services in one health system.

\section{Conceptual model}

The study was guided by the Conceptual Model for the Association of Electronic Health Record (EHR) Use on Quality of Care for Patients Diagnosed with Type 2 Diabetes. This model was adapted from the Health Care Quality Model developed by Donabedian and the structural variables from the Triangle model developed by Ancker, Kern, Abramson, and Kaushal. ${ }^{38-40}$ These two models theorize how the use of EHRs affects the quality of care in patients with type 2 diabetes (see Figure 1).

Figure 1 shows that structure, process, and outcome have causal and linear relationships, meaning good structures improve the likelihood of good process, and good processes improve the likelihood of good outcomes. ${ }^{38-39}$ Thus, in relation to this study, if the EHR system is implemented or installed in a health care organization (structure) and clinicians meaningfully use EHRs to provide care that adheres to the best practice guidelines for diabetes care embedded in the EHR (process), patients diagnosed with type 2 diabetes will be able to achieve the recommended outcomes of diabetes care. 


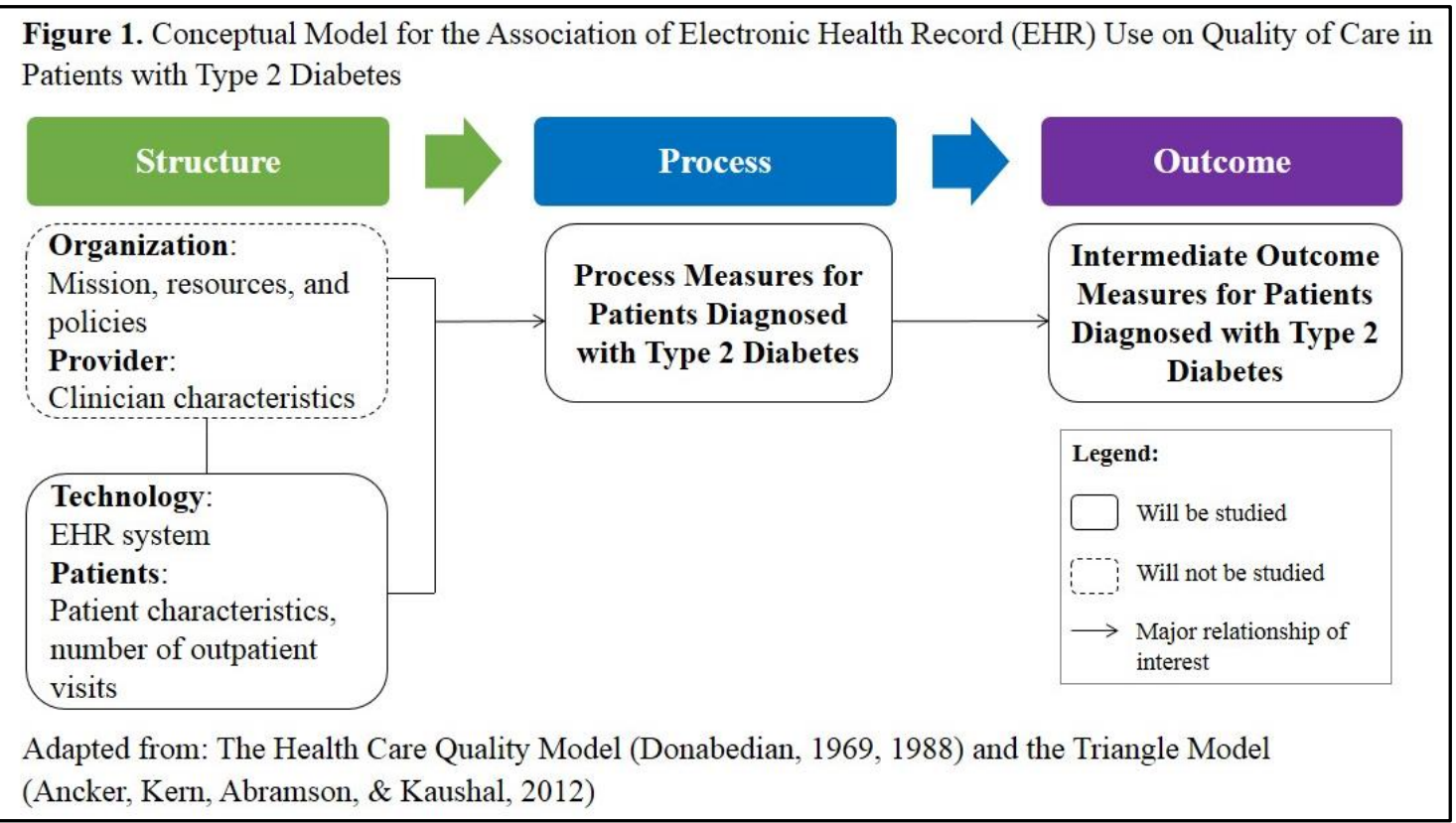

\section{METHODS}

\section{Study design and data sources}

A longitudinal, secondary data analysis was used to address the specific aims of this study. This study used data from one hospital's Clinical Data Repository (CDR) and EpicCare system. ${ }^{41-42}$ The CDR is a de-identified data warehouse of patients who visited one university-based teaching hospital system located in Central Virginia. It contains more than 15 years of patient information, drawn from the hospital system's multiple clinics and the Virginia Department of Health. ${ }^{41}$ The EpicCare system is an Electronic Medical Record (EMR) system owned by the Epic System Corporation. It has been used in 185 health care organizations throughout the US and has been reported as having several advantages including cost savings and patient safety enhancement. ${ }^{42}$

\section{Setting and sample}

The study site was a 600-bed university hospital located in Central Virginia. Inclusion criteria for the sample were all patients aged 18-75 years with the principal 
diagnosis of type 2 diabetes based on the ICD-9-CM (DX 250.xx). All patients had outpatient visits in all three time points: pre-EHR (07/01/2009-06/30/2010), one year post-EHR (07/01/2011-06/30/2012), and two years post-EHR (07/01/2012-06/30/2013). Patients aged $\geq 76$ years were not included in this study because HbA1c level significantly increases with age and therefore may affect the variance of the data as an increase may not be related to care. ${ }^{23}$ The study included a total of 1,201 patients diagnosed with type 2 diabetes who had visits to five types of outpatient services and had values at all-time points. The five outpatient services included diabetes services, endocrinology, family medicine, internal medicine, and cardiology.

\section{Power analysis}

Power analysis was conducted to estimate the required number of paired samples for each time period. For this study, a pilot sample of 206 patients diagnosed with type 2 diabetes was randomly selected across the three year study period from the CDR. Since the same patients were examined over time, a McNemar's test was used to test any differences in the proportion of these 206 patients receiving HbA1c tests pre- and one year post-EHR. The calculation of the McNemar's test was run using the nQuery program. $^{43}$

Table 1 presents results of the McNemar's test for the 206 patients. There were $172(83.5 \%)$ patients who received HbA1c test one year post-EHR and $143(69.4 \%)$ received it pre-EHR, which means there was a $14 \%$ difference in the proportions; this is also known as effect size (ES). Furthermore, the McNemar's test demonstrated that of 206 patients, 24 received HbA1c tests only in pre-EHR, but not in one year post-EHR and 53 who received HbA1c tests in one year post-EHR, but not in pre-EHR. Those 77 
patients are called discordant pairs and the proportion of those discordant pairs

constituted $37 \%$ of the sample. ${ }^{43}$

Table 1

McNemar's Test for Power Analysis of Pilot Sample $(n=206)$

\begin{tabular}{|l|l|r|r|r|}
\hline \multicolumn{2}{|c|}{} & \multicolumn{3}{|c|}{ One Year Post-EHR } \\
\cline { 3 - 6 } \multicolumn{2}{|c|}{} & Not Received HbA1c Tests & Received HbA1c Tests & Total \\
\hline \multirow{3}{*}{ Pre-EHR } & Not Received HbA1c Tests & 10 & 53 & 63 \\
\cline { 2 - 5 } & Received HbA1c Tests & 24 & 119 & 143 \\
\cline { 2 - 5 } & Total & 34 & 172 & 206 \\
\hline
\end{tabular}

Since the ES of our pilot sample was $14 \%$, we anticipated the ES for process and intermediate outcome measures of this study was around $10 \%-15 \%$. Moreover, as the proportion of discordant pairs from our pilot sample was $37 \%$ or 0.4 , we assumed the proportion of discordant pairs for our study ranged from 0.2 to 0.4 . Based on our pilot data, we ran the nQuery program to calculate the required number of samples for our study. ${ }^{43}$ For this calculation, we used $10 \%$ ES instead of $15 \%$ ES because a smaller ES requires a greater sample size. Furthermore, we used $90 \%, 85 \%$, and $80 \%$ power with a 2-sided significance level of 0.05 . As shown in Table 2, the required number of subjects started from 193 to 412 at $90 \%$, decreased to $167-353$ at $85 \%$, and fell further to $148-309$ at $80 \%$ power. Since the number of subjects we had was 1,201 , these were much greater than $90 \%$ power.

Table 2

Estimated Required Number of Subjects Assuming a 2-Sided Significance Level of 0.05

\begin{tabular}{|c|c|c|c|c|}
\hline \multirow{2}{*}{$\begin{array}{c}\text { Detectable effect size } \\
\text { (difference in post-pre } \\
\text { proportions) }\end{array}$} & \multirow{2}{*}{$\begin{array}{c}\text { Proportion of discordant } \\
\text { pairs }\end{array}$} & \multicolumn{3}{|c|}{ Required number of subjects } \\
\hline & & $\begin{array}{l}80 \% \\
\text { power }\end{array}$ & $\begin{array}{c}85 \% \\
\text { power }\end{array}$ & $\begin{array}{l}90 \% \\
\text { power }\end{array}$ \\
\hline $10 \%$ & 0.2 & 148 & 167 & 193 \\
\hline $10 \%$ & 0.3 & 229 & 261 & 304 \\
\hline $10 \%$ & 0.4 & 309 & 353 & 412 \\
\hline
\end{tabular}




\section{Study measures}

Study measures were grouped into three concepts: structure, process, and outcomes, according to the study's conceptual model..$^{38-39}$

\section{Structure}

Two structural elements were examined in this study, technology and patients. The use of an EHR system was conceptualized as technology, while patient characteristics and number of outpatient visits was conceptualized as patients.

An EHR is defined as a longitudinal electronic record that contains complete patient health information generated from one or more clinical encounters in any care delivery setting. ${ }^{44}$ In this study, quality of diabetes care for patients diagnosed with type 2 diabetes was measured at three time points: pre-EHR, one year post-EHR, and two years post-EHR. Pre-EHR was defined as a period of time (07/01/2009-06/30/2010) when the EHR system was not used in the studied health system. One year post-EHR was defined as one year after all studied units adopted EHRs (07/01/2011-06/30/2012). Then, two years post-EHR was defined as two years after all studied units adopted EHRs (07/01/2012-06/30/2013).

The second element of the structure was patient characteristics, including age, race, sex, and type of health insurance. Data about patient characteristics were extracted from the CDR, and only patient characteristics at the baseline were included in the statistical analysis. In terms of operational definitions, age was defined as the age, in years, of patients diagnosed with type 2 diabetes at the time of service. In this study, age was measured as categorical data for sample characteristics in order to compare with the CDC data and as continuous data for multiple regression analysis. There were three 
categories of patients depending on their ages: patients aged 19-44 years, patients aged 45-64 years, and patients aged 65-74 years. The second patient characteristic in this study was sex coded as male or female. ${ }^{45}$ The third patient characteristic was race, and it was defined as the self-reported of race of patients diagnosed with type 2 diabetes. There were three types of race included in this study: white, black, and other. The fourth patient characteristic was type of health insurance, which was the primary insurance the patient carried. There were four categories for health insurance: Medicare (Medicare and Medicare Advantage), Medicaid (Medicaid and Medicaid HMO), uninsured (self-pay and uninsured), private (AETNA, ANTHEM, Blue Cross, CIGNA, OPTIMA Health, South Health, and United), and other (CHAMPVA, TRICARE, and US Military ID). The "other" category was used for patients who had health insurance paid by the US Military Health Plan. The CHAMPVA stands for the Civilian Health and Medical Program of the Department of Veterans Affairs.

The third element of the structure was number of outpatient visits, which was defined as total visits made by patients diagnosed with type 2 diabetes to the following outpatient services: diabetes services, endocrinology, family medicine, internal medicine, and cardiology, which were documented in the EpicCare system and the CDR.

\section{Process and intermediate outcome measures for diabetes care quality}

In this study, quality of diabetes care was assessed using process and intermediate outcome measures developed by the National Diabetes Quality Improvement Alliance [NDQIA] (2005). According to the 2005 NDQIA, the diabetes quality performance measures consist of two measures: process measures and outcome measures (intermediate outcome measures and long-term outcome measures). ${ }^{21,24}$ Process measures are defined 
as measures that reflect diabetes care guidelines, while intermediate outcome measures are defined as measures that aim to achieve specific thresholds of clinical care, such as physiological or biochemical values, which have been shown to affect the desired health outcomes positively or adversely. ${ }^{24}$ Moreover, long-term outcome measures are defined as measures including complications and mortality. ${ }^{21}$ However, the long-term measures are not ideal to assess quality of care over the short-term period. ${ }^{21}$ Thus, since the focus of this proposed study was to examine subject-specific changes over three years (shortterm) after receiving diabetes care, these long-term outcome measures could not be evaluated in this study.

\section{Process measures}

In this study, process measures consisted of two measures. The first measure was frequency, which was defined as the number of $\mathrm{HbA1c}, \mathrm{BP}$, and lipid profile tests documented for each patient diagnosed with type 2 diabetes when this patient visited outpatient services at each time point. The second measure was proportion, which was defined as number of patients who had at least one or more HbA1c, BP, and lipid profile test(s) documented at each time point, divided by all patients diagnosed with type 2 diabetes aged between 18 and 75 years who had outpatient visits at the three time points $(\mathrm{n}=1,201)$. To calculate this proportion, all patients who had at least one or more HbA1c, BP, and lipid profile tests documented at each time point were coded as 1; those patients who did not have any HbA1c, BP, and lipid profile tests were coded as 0.

The operational definitions for HbA1c, BP, and lipid profile are as follows. HbA1c is defined as a fraction of the minor hemoglobin (HbA1) that is formed by the reaction of glucose and the globin of hemoglobin that occurs spontaneously (no enzyme 
required) during the erythrocytes' exposure to the plasma. ${ }^{46}$ Thus, the actual amount of HbA1c depends on the concentration of glucose that erythrocytes are exposed to during their life span (120 days). ${ }^{47}$ The HbA1c level is an important measurement as it indicates the average level of glucose in the blood over the preceding 3 months, which is used to predict risk of long-term diabetes complications. ${ }^{48}$ The 2005 NDQIA recommended that HbA1c be measured at least twice a year. ${ }^{22}$

$\mathrm{BP}$ is defined as the arterial pressure produced during a cardiac cycle. ${ }^{49} \mathrm{It}$ comprises systolic and diastolic pressure. Systolic pressure is defined as the highest arterial pressure measured during a cardiac cycle, especially after blood has been ejected from the left ventricle during systole. Meanwhile, diastolic pressure is defined as the lowest arterial pressure measured during a cardiac cycle, especially during ventricular relaxation when no blood is being ejected from the left ventricle. ${ }^{49} \mathrm{BP}$ controls at every patient encounter were examined because, by reading and recording the patient BP value, the clinician could discover the BP level. Thus, if the BP level was high, a treatment would be provided to the patient in order to decrease risk for diabetes complications, mainly congestive heart failure. ${ }^{22}$ The 2005 NDQIA recommended that BP needs to be measured at every routine diabetes visit. ${ }^{22}$

The third variable in process measures was lipid profile, particularly total cholesterol, HDL-C, LDL-C and triglycerides. It is important to check patients' lipid profiles because patients diagnosed with type 2 diabetes tend to develop dyslipidemia, which is one of the causes of coronary heart disease (CHD). ${ }^{50}$ Diabetic dyslipidemia consists of an elevation in LDL-C and triglyceride levels and low HDL-C values. ${ }^{50}$ 
According to the 2005 NDQIA, patients diagnosed with diabetes should receive at least one lipid profile measurement per year. ${ }^{22}$

\section{Intermediate outcome measures}

In this study, intermediate outcome measures comprise levels of $\mathrm{HbA1c}, \mathrm{BP}$, and lipid profile achieved by each patient in each time point and the proportion of patients achieving the intermediate outcome level as recommended by the 2005 NDQIA. ${ }^{22}$ The operational definitions for levels and proportions of these intermediate outcome measures are explained below.

In accordance with the 2005 NDQIA guidelines, level of HbAlc was defined as the most recent HbA1c value (\%) achieved by each patient per year. Levels of BP were defined as the most recent systolic and diastolic BP value ( $\mathrm{mmHg}$ ) achieved by each patient per year. Finally, level of lipid profile was defined as the most recent total cholesterol, HDL-C, LDL-C, and triglycerides values (mg/dL) achieved by each patient per year. The measurement levels for all of these variables were continuous.

As mentioned previously, the second measurement for intermediate outcomes was proportion of patients achieving the recommended $\mathrm{HbA} 1 \mathrm{c}, \mathrm{BP}$, and lipid profile levels. It is important to lower $\mathrm{HbA1c}, \mathrm{BP}$ and lipid profile levels to recommended levels because this can reduce microvascular and macrovascular complications. ${ }^{22}$ To calculate the proportion of patients achieving the recommended intermediate outcome levels, all patients who had $\mathrm{HbA1c}, \mathrm{BP}$, and lipid profile tests documented and achieved the intermediate outcome level as recommended by the 2005 NDQIA were coded as 1, while those patients who had the tests documented, but did not achieve any recommended intermediate outcome levels were coded as 0 . 
In conjunction with the calculation above, the proportion of patients achieving the recommended HbAlc level was defined as number of patients with most recent HbA1c level less than or equal to $7 \%$ for the year, divided by all patients diagnosed with type 2 diabetes aged between 18 and 75 years who had HbA1c tests documented. The proportion of patients achieving the recommended BP level was defined as number of patients with most recent systolic BP (SBP) level below $140 \mathrm{mmHg}$ and diastolic BP (DBP) level below $80 \mathrm{mmHg}$ for the year, divided by all patients diagnosed with type 2 diabetes aged between 18 and 75 years who had BP measurements documented. Ultimately, the proportion of patients achieving the recommended lipid profile levels was defined as number of patients with most recent total cholesterol level less than 170 mg/dL, HDL-C level greater than $45 \mathrm{mmHg}$, LDL-C level below 100mg/dL, and triglycerides level less than $150 \mathrm{mg} / \mathrm{dL}$ for the year, divided by all patients diagnosed with type 2 diabetes aged between 18 and 75 years who had lipid profile measurements documented. ${ }^{22}$

\section{Data management}

In this study, patient characteristics, $\mathrm{HbA1c}, \mathrm{BP}$, and lipid profile post-EHR were extracted from the CDR. As patients' vital signs in the CDR have been available only since October 2010, the pre-EHR BP data were queried from the EpicCare system through chart review. The procedures to obtain the pre-EHR BP data are explained below.

First, the principal investigator (PI) defined the studied population in the CDR based on the selection criteria. Then, the PI requested names and medical record numbers (MRNs) of the selected patients $(n=1,201)$ to access their medical records in the 
EpicCare system in order to obtain their BP values pre-EHR. Afterwards, the PI entered the patients' names and MRNs into the EpicCare system to view their charts. Next, the PI used filters (date range, department specialty, and document type) to directly look up the chart of the patient's visit to the diabetes services, endocrinology, family medicine, internal medicine, and cardiology during pre-EHR. The patients' pre-EHR BP data were found in the scanned document of their "Progress Note/Letter," particularly in the physical examination section.

\section{Ethical considerations}

Institutional Review Board for Health Sciences Research (IRB-HSR) approval was obtained prior to chart review from the EpicCare system and prior to data analysis. Patient confidentiality was carefully protected as ruled by the Health Insurance Portability and Accountability Act (HIPAA) regulations. ${ }^{51}$ In a different data set, each patient was assigned a code number and the PI used that number for all data about the patient. These data sets, then, were stored in two different files, one file containing only patients' names and MRNs and another file including only patients' health information without any identifiers, except for the code number. Both files were protected with encrypted passwords. The file consisting of patients' names and MRNs was used to link and to retrieve patient's BP values recorded in the EpicCare system. The study data sets were stored in the shared drive F managed by the Health System Computing Services where the study was conducted with an encrypted password, which was only known by the PI. At the completion of this study, all patient data were destroyed. 


\section{Data analysis}

Crosstabs and chi-square tests were performed to check missing patterns of all dependent variables by patient characteristics (age, sex, race, and type of health insurance). Descriptive statistics including means (M), standard deviations (SD), and frequencies were calculated to describe the sample. Descriptive statistics were also used to report frequency of process measures and intermediate outcome levels at the three time points. McNemar's tests were used to examine differences in a) the proportion of patients who had at least one process measure documented and b) the proportion of patients achieving the recommended intermediate outcome levels between two time points (preEHR vs. one year post-EHR, and pre-EHR vs. two years post-EHR). Paired sample $t$-tests were used to examine mean differences in a) frequency of process measures documented and b) intermediate outcome levels between two time points (pre-EHR vs.one year postEHR, and pre-EHR vs. two years post-EHR).

Prior to this analysis, all assumptions were checked including normality and collinearity. Since SBP and DBP data were positively skewed, we decided to use the mean of the last three SBP and DBP levels instead of using the mean of the most recent SBP and DBP levels, for the paired sample $t$-tests and multiple regressions.

Multiple regressions were used to examine the effect of patient characteristics on intermediate outcome levels at one year, and two years post-EHR. ${ }^{52}$ In the multiple regressions, after controlling for each pre-EHR intermediate outcome level, patient characteristics (age, race, sex, and type of health insurance) were used to predict first $\mathrm{HbA1c}, \mathrm{BP}$, lipid profile at one year and then at two years post-EHR. Thus, in total 14 
multiple regression analyses were conducted. Data were analyzed using SPSS (PASW Statistics version 18), ${ }^{53}$ and the level of significance was set at 0.05 , two-tailed.

\section{RESULTS}

\section{Patient characteristics}

Characteristics of the patients are shown in Table 3. More than half of these patients were 45-64 years of age (55.5\%), one-third of them were aged 65-74 years $(33.1 \%)$, and the remaining patients were aged $19-44$ years $(11.4 \%)$. Over half of them were women $(52.3 \%)$, and the majority was white $(68.4 \%)$, followed by black $(26.1 \%)$ and other races $(5.4 \%)$. With regard to type of health insurance, $43.3 \%$ of patients were covered by Medicare, followed by private insurance (35.5\%), Medicaid (5.7\%), and another type of health insurance, such as the US Military Health Plan (1.7\%). Of these patients, $13.8 \%$ were not covered by any form of health insurance.

\begin{tabular}{|c|c|c|}
\hline & Frequency & Percent \\
\hline \multicolumn{3}{|l|}{ Age (Years) } \\
\hline $19-44$ & 137 & 11.4 \\
\hline $45-64$ & 666 & 55.5 \\
\hline $65-74$ & 398 & 33.1 \\
\hline \multicolumn{3}{|l|}{ Sex } \\
\hline Female & 628 & 52.3 \\
\hline Male & 573 & 47.7 \\
\hline \multicolumn{3}{|l|}{ Race } \\
\hline White & 822 & 68.4 \\
\hline Black & 314 & 26.1 \\
\hline Other & 65 & 5.4 \\
\hline \multicolumn{3}{|c|}{ Type of Health Insurance } \\
\hline Medicare & 520 & 43.3 \\
\hline Medicaid & 68 & 5.7 \\
\hline Uninsured & 166 & 13.8 \\
\hline Private & 426 & 35.5 \\
\hline Other & 21 & 1.7 \\
\hline
\end{tabular}




\section{Number of outpatient visits}

During pre-EHR, the 1,201 patients had 5,363 outpatient visits with the mean number of visits of $4.5(S D=3.7)$. One year after EHR implementation, these patients had 5,421 outpatient visits with an average number of visits of $4.5(S D=4.3)$. Two years after the EHR implementation, the outpatient visits increased by $43 \%$ from the previous year to a mean number of visit of $6.4(S D=5.7)$.

Likewise, number of visits with BP measurements recorded had risen from $49.1 \%$ $(2,631)$ of 5,363 outpatient visits in pre-EHR to $68.6 \%(3,722)$ of 5,421 outpatient visits in one year post-EHR, and to $70.9 \%(5,490)$ of 7,744 outpatient visits in two years postEHR. In contrast, number of visits with documented lipid profile measurements decreased over time. Moreover, the trend in HbA1c differed slightly from BP and lipid profile as number of visits with documented HbA1c only increased from pre-EHR to one year post-EHR, but decreased two years post-EHR (see Table 4).

Table 4

Number of Outpatient Visits by 1,201 Patients at Three Time Points

\begin{tabular}{|c|c|c|c|}
\hline Number of Visits & $\begin{array}{l}\text { Pre-EHR } \\
n(M, S D)\end{array}$ & $\begin{array}{l}\text { One Year Post- } \\
\text { EHR } n(M, S D)\end{array}$ & $\begin{array}{l}\text { Two Years Post- } \\
\text { EHR } n(M, S D)\end{array}$ \\
\hline Number of outpatient visits & $\begin{array}{r}5,363 \\
(M=6.4, S D=5.7)\end{array}$ & $\begin{array}{r}5,421 \\
(M=4.5, S D=4.3) \\
\end{array}$ & $\begin{array}{r}7,744 \\
(M=6.4, S D=5.7) \\
\end{array}$ \\
\hline $\begin{array}{l}\text { Number of visits with documented HbA1c } \\
\text { measurement }\end{array}$ & $\begin{array}{r}2,566 \\
(M=2.4, S D=1) \\
\end{array}$ & $\begin{array}{r}2,593 \\
(M=2.4, S D=1.1) \\
\end{array}$ & $\begin{array}{r}2,401 \\
(M=2.3, S D=1) \\
\end{array}$ \\
\hline $\begin{array}{l}\text { Number of visits with documented BP } \\
\text { measurement }\end{array}$ & $\begin{array}{r}2,631 \\
(M=4, S D=3.1) \\
\end{array}$ & $\begin{array}{r}3,722 \\
(M=4.1, S D=3.6)\end{array}$ & $\begin{array}{r}5,490 \\
(M=4.9, S D=3.7) \\
\end{array}$ \\
\hline $\begin{array}{l}\text { Number of visits with documented total } \\
\text { cholesterol measurement }\end{array}$ & $\begin{array}{r}1,731 \\
(M=1.8, S D=1)\end{array}$ & $\begin{array}{r}1,712 \\
(M=1.7, S D=1)\end{array}$ & $\begin{array}{r}1,587 \\
(M=1.6, S D=0.9) \\
\end{array}$ \\
\hline $\begin{array}{l}\text { Number of visits with documented HDL } \\
\text { cholesterol measurement }\end{array}$ & $\begin{array}{r}1,721 \\
(M=1.8, S D=1) \\
\end{array}$ & $\begin{array}{r}1,703 \\
(M=1.7, S D=1) \\
\end{array}$ & $\begin{array}{r}1,585 \\
(M=1.6, S D=0.9) \\
\end{array}$ \\
\hline $\begin{array}{l}\text { Number of visits with documented LDL } \\
\text { cholesterol measurement }\end{array}$ & $\begin{array}{r}1,660 \\
(M=1.8, S D=1) \\
\end{array}$ & $\begin{array}{r}1,632 \\
(M=1.7, S D=1) \\
\end{array}$ & $\begin{array}{r}1,515 \\
(M=1.6, S D=0.8) \\
\end{array}$ \\
\hline $\begin{array}{l}\text { Number of visits with documented } \\
\text { triglycerides measurement }\end{array}$ & $\begin{array}{r}1,725 \\
(M=1.8, S D=1)\end{array}$ & $\begin{array}{r}1,700 \\
(M=1.7, S D=1)\end{array}$ & $\begin{array}{r}1,581 \\
(M=1.6, S D=0.9)\end{array}$ \\
\hline
\end{tabular}

Note. $M=$ Mean; $S D=$ Standard Deviation. 


\section{Differences in process measures}

Differences in process measures are explained based on the frequency of $\mathrm{HbA1c}$,

$\mathrm{BP}$, and lipid profile tests documented for each patient and the proportion of patients who

had at least one HbA1c, BP, and lipid profile tests documented in each time point.

Table 5

Mean Differences in Frequency of Process Measures Documented for Patients Diagnosed with Type 2

Diabetes at Three Time Points

\begin{tabular}{|c|c|c|c|c|c|}
\hline \multirow[t]{2}{*}{ Process Measures } & Pre-EHR & $\begin{array}{c}\text { One Year } \\
\text { Post- } \\
\text { EHR }\end{array}$ & $\begin{array}{c}\text { Two } \\
\text { Years } \\
\text { Post- } \\
\text { EHR }\end{array}$ & \multirow[t]{2}{*}{$\begin{array}{c}p \text { value } \\
\text { Pre-EHR vs. } \\
\text { One Year } \\
\text { Post-EHR }\end{array}$} & \multirow[t]{2}{*}{$\begin{array}{c}p \text { value } \\
\text { Pre-EHR vs. } \\
\text { Two Years } \\
\text { Post-EHR }\end{array}$} \\
\hline & $M(S D)$ & $M(S D)$ & $M(S D)$ & & \\
\hline \multicolumn{6}{|l|}{ HbA1c measurement } \\
\hline $\begin{array}{l}\text { Pre-EHR vs. One Year Post-EHR, } \\
n^{\mathrm{a}}=1,025(100 \%)\end{array}$ & $2.4(1)$ & $2.4(1.1)$ & & 0.563 & \\
\hline $\begin{array}{l}\text { Pre-EHR vs. Two Years Post- } \\
\text { EHR, } n^{\mathrm{a}}=988(100 \%)\end{array}$ & $2.4(1)$ & & $2.3(1)$ & & $0.007 *$ \\
\hline \multicolumn{6}{|l|}{ BP measurement } \\
\hline $\begin{array}{l}\text { Pre-EHR vs. One Year Post-EHR, } \\
n^{\mathrm{a}}=640(100 \%)\end{array}$ & $4.1(3.1)$ & $4.9(3.9)$ & & $0.000 *$ & \\
\hline $\begin{array}{l}\text { Pre-EHR vs. Two Years Post- } \\
\text { EHR, } n^{\mathrm{a}}=652(100 \%)\end{array}$ & $4(3.1)$ & & $5.2(4)$ & & $0.000 *$ \\
\hline \multicolumn{6}{|l|}{ Total cholesterol measurement } \\
\hline $\begin{array}{l}\text { Pre-EHR vs. One Year Post-EHR, } \\
n^{\mathrm{a}}=826(100 \%)\end{array}$ & $1.9(1.1)$ & $1.8(1.1)$ & & 0.076 & \\
\hline $\begin{array}{l}\text { Pre-EHR vs. Two Years Post- } \\
\text { EHR, } n^{\mathrm{a}}=818(100 \%)\end{array}$ & $1.8(1.1)$ & & $1.7(0.9)$ & & $0.000 *$ \\
\hline \multicolumn{6}{|l|}{ HDL-C measurement } \\
\hline $\begin{array}{l}\text { Pre-EHR vs. One Year Post-EHR, } \\
n^{\mathrm{a}}=818(100 \%)\end{array}$ & $1.9(1.1)$ & $1.8(1)$ & & 0.079 & \\
\hline $\begin{array}{l}\text { Pre-EHR vs. Two Years Post- } \\
\text { EHR, } n^{\mathrm{a}}=815(100 \%)\end{array}$ & $1.9(1.1)$ & & $1.7(0.9)$ & & $0.000 *$ \\
\hline \multicolumn{6}{|l|}{ LDL-C measurement } \\
\hline $\begin{array}{l}\text { Pre-EHR vs. One Year Post-EHR, } \\
n^{\mathrm{a}}=792(100 \%)\end{array}$ & $1.9(1.1)$ & $1.8(1)$ & & 0.096 & \\
\hline $\begin{array}{l}\text { Pre-EHR vs. Two Years Post- } \\
\text { EHR, } n^{\mathrm{a}}=786(100 \%)\end{array}$ & $1.8(1.1)$ & & $1.7(0.9)$ & & $0.000 *$ \\
\hline \multicolumn{6}{|l|}{ Triglycerides measurement } \\
\hline $\begin{array}{l}\text { Pre-EHR vs. One Year Post-EHR, } \\
n^{\mathrm{a}}=818(100 \%)\end{array}$ & $1.9(1.1)$ & $1.8(1)$ & & 0.075 & \\
\hline $\begin{array}{l}\text { Pre-EHR vs. Two Years Post- } \\
\text { EHR, } n^{\mathrm{a}}=815(100 \%)\end{array}$ & $1.9(1.1)$ & & $1.7(0.9)$ & & $0.000 *$ \\
\hline
\end{tabular}

Note. $n^{\mathrm{a}}=$ Number of patients who had process measures documented in two time point comparisons; ${ }^{*} p$ $=0.05$ from paired sample $t$-tests.

Table 5 summarizes the mean differences in frequency of $\mathrm{HbA1c}, \mathrm{BP}$, and lipid profile measurements documented for each patient between two time points (from pre- 
EHR to one year post-EHR, and from pre-EHR to two years post-EHR). The frequency of BP control documentation significantly increased from pre-EHR $(M=4.1, S D=3.1)$ to one year post-EHR $(M=4.9, S D=3.9)$, and from pre-EHR $(M=4, S D=3.1)$ to two years post-EHR $(M=5.2, S D=4)$. In contrast, the frequency of HbA1c and lipid profile test documentation significantly decreased from pre-EHR to two years post-EHR $(M=$ 2.4, $S D=1$ vs. $M=2.3, S D=1$ and $M=1.8, S D=1.1$ vs. $M=1.7, S D=0.9$, respectively).

Table 6 presents differences in proportions of patients who had at least one HbA1c test, BP control, and lipid profile measurement documented between two time points (from pre-EHR to one year post-EHR, and from pre-EHR to two years post-EHR). As shown in Table 6, the proportion of patients who had at least one BP control documented significantly increased from pre-EHR to one year post-EHR (55\% vs. 74.9\%) and from pre-EHR to two years post-EHR (55\% vs. 93.9\%). Of more than half of 1,201 patients who had at least one BP control documented in pre-EHR, 72.4\% (478 patients) received diabetes care from primary care practices (family medicine and internal medicine), and the remaining patients received diabetes care from the specialty care practices (cardiology, diabetes services, and endocrinology). Likewise, of three quarters of 1,201 patients who had at least one BP control documented in one year post-EHR, $72.4 \%$ (651 patients) received diabetes care from primary care practices, while the rest received diabetes care from the specialty care practices. Furthermore, of 1,128 patients (93.9\% of 1,201 patients) who had at least one BP control documented in two years postEHR, 82.7\% (933 patients) received diabetes care from primary care practices, and only $17.3 \%$ received diabetes care from the specialty care. 
Another significant result was also found in the HbA1c. However, the proportion of patients who had at least one HbA1c test documented significantly dropped from pre-

EHR to two years post-EHR (90.8\% vs. $87.6 \%)$.

Table 6

Differences in Proportion of Patients who Had At Least One Process Measure Documented at Three

Time Points $(n=1,201)$

\begin{tabular}{|c|c|c|c|c|c|}
\hline Process Measures & Pre-EHR & $\begin{array}{c}\text { One Year } \\
\text { Post-EHR } \\
n^{\mathrm{a}}(\%)\end{array}$ & $\begin{array}{c}\text { Two Years } \\
\text { Post-EHR } \\
n^{\mathrm{a}}(\%)\end{array}$ & $\begin{array}{c}p \text { value } \\
\text { Pre-EHR vs. } \\
\text { One Year } \\
\text { Post-EHR }\end{array}$ & $\begin{array}{c}p \text { value } \\
\text { Pre-EHR vs. } \\
\text { Two Years } \\
\text { Post-EHR }\end{array}$ \\
\hline \multicolumn{6}{|l|}{ HbA1c measurement } \\
\hline $\begin{array}{l}\text { Pre-EHR vs. One Year Post- } \\
\text { EHR, } n^{\mathrm{b}}=1,201(100 \%)\end{array}$ & $\begin{aligned} 1,091 \\
(90.8) \\
\end{aligned}$ & $\begin{array}{r}1,094 \\
(91.1) \\
\end{array}$ & & 0.863 & \\
\hline $\begin{array}{l}\text { Pre-EHR vs. Two Years Post- } \\
\text { EHR, } n^{\mathrm{b}}=1,201(100 \%)\end{array}$ & $\begin{aligned} 1,091 \\
(90.8)\end{aligned}$ & - & $\begin{array}{r}1,052 \\
(87.6)\end{array}$ & - & 0.003* \\
\hline \multicolumn{6}{|l|}{ SBP measurement } \\
\hline $\begin{array}{l}\text { Pre-EHR vs. One Year Post- } \\
\text { EHR, } n^{\mathrm{b}}=1,201(100 \%)\end{array}$ & $\begin{array}{r}660 \\
(55.0)\end{array}$ & $899(74.9)$ & & $0.000 *$ & \\
\hline $\begin{array}{l}\text { Pre-EHR vs. Two Years Post- } \\
\text { EHR, } n^{\mathrm{b}}=1,201(100 \%)\end{array}$ & $\begin{array}{r}660 \\
(55.0)\end{array}$ & - & $\begin{array}{r}1,128 \\
(93.9)\end{array}$ & - & $0.000 *$ \\
\hline \multicolumn{6}{|l|}{ DBP measurement } \\
\hline $\begin{array}{l}\text { Pre-EHR vs. One Year Post- } \\
\text { EHR, } n^{\mathrm{b}}=1,201(100 \%)\end{array}$ & $\begin{array}{r}660 \\
(55.0) \\
\end{array}$ & $899(74.9)$ & & $0.000 *$ & \\
\hline $\begin{array}{l}\text { Pre-EHR vs. Two Years Post- } \\
\text { EHR, } n^{\mathrm{b}}=1,201(100 \%)\end{array}$ & $\begin{array}{r}660 \\
(55.0)\end{array}$ & - & $\begin{array}{l}1,128 \\
(93.9)\end{array}$ & - & $0.000 *$ \\
\hline \multicolumn{6}{|l|}{ Total cholesterol measurement } \\
\hline $\begin{array}{l}\text { Pre-EHR vs. One Year Post- } \\
\text { EHR, } n^{\mathrm{b}}=1,201(100 \%)\end{array}$ & $\begin{array}{r}953 \\
(79.4) \\
\end{array}$ & $980(81.6)$ & - & 0.121 & \\
\hline $\begin{array}{l}\text { Pre-EHR vs. Two Years Post- } \\
\text { EHR, } n^{\mathrm{b}}=1,201(100 \%)\end{array}$ & $\begin{array}{r}953 \\
(79.4)\end{array}$ & - & $966(80.4)$ & - & 0.476 \\
\hline \multicolumn{6}{|l|}{ HDL-C measurement } \\
\hline $\begin{array}{l}\text { Pre-EHR vs. One Year Post- } \\
\text { EHR, } n^{\mathrm{b}}=1,201(100 \%)\end{array}$ & $\begin{array}{r}948 \\
(78.9)\end{array}$ & $974(81.1)$ & - & 0.139 & - \\
\hline $\begin{array}{l}\text { Pre-EHR vs. Two Years Post- } \\
\text { EHR, } n^{\mathrm{b}}=1,201(100 \%)\end{array}$ & $\begin{array}{r}948 \\
(78.9) \\
\end{array}$ & & $966(80.4)$ & - & 0.313 \\
\hline \multicolumn{6}{|l|}{ LDL-C measurement } \\
\hline $\begin{array}{l}\text { Pre-EHR vs. One Year Post- } \\
\text { EHR, } n^{\mathrm{b}}=1,201(100 \%)\end{array}$ & $\begin{array}{r}929 \\
(77.4)\end{array}$ & $950(79.1)$ & - & 0.244 & - \\
\hline $\begin{array}{l}\text { Pre-EHR vs. Two Years Post- } \\
\text { EHR, } n^{\mathrm{b}}=1,201(100 \%)\end{array}$ & $\begin{array}{r}929 \\
(77.4)\end{array}$ & - & $943(78.5)$ & - & 0.453 \\
\hline \multicolumn{6}{|l|}{ Triglycerides measurement } \\
\hline $\begin{array}{l}\text { Pre-EHR vs. One Year Post- } \\
\text { EHR, } n^{\mathrm{b}}=1,201(100 \%)\end{array}$ & $\begin{array}{r}948 \\
(78.9)\end{array}$ & $972(80.9)$ & - & 0.172 & \\
\hline $\begin{array}{l}\text { Pre-EHR vs. Two Years Post- } \\
\text { EHR, } n^{\mathrm{b}}=1,201(100 \%)\end{array}$ & $\begin{array}{r}948 \\
(78.9)\end{array}$ & & $965(80.3)$ & - & 0.342 \\
\hline
\end{tabular}

Note. $n^{\mathrm{a}}=$ Number of patients who had at least one process measure documented; $n^{\mathrm{b}}=$ Number of patients who had outpatient visits at the three time points; * $p=0.05$ from McNemar's tests. 


\section{Differences in intermediate outcome measures}

Differences in intermediate outcome measures are explained based on: firstly, the differences in the proportion of patients achieving the recommended intermediate outcome levels; and secondly, the mean differences in intermediate outcome levels achieved by the same patients diagnosed with type 2 diabetes.

Table 7 indicates that the proportions of patients achieving the recommended HbA1c level of $\leq 7 \%$ were significantly different from pre-EHR to one year post-EHR, and from pre-EHR to two years post-EHR. The proportion of patients achieving the recommended HbA1c level one year post-EHR was lower than pre-EHR (39.9\% vs. 49.6\%). Likewise, the proportion of patients achieving the recommended HbAlc level two years post-EHR was lower than pre-EHR (38.9\% vs. 49.9\%).

A significant difference also emerged in the proportion of patients achieving the recommended SBP level of $<140 \mathrm{mmHg}$ from pre-EHR to one year post-EHR. The proportion of patients achieving the recommended SBP level one year post-EHR was lower than pre-EHR (73.4\% vs. $78.1 \%)$.

The last significant difference was found in the proportion of patients achieving the recommended total cholesterol of $<170 \mathrm{mg} / \mathrm{dL}$ from pre-EHR to two years post-EHR. The proportion of patients achieving the recommended total cholesterol level two years post-EHR was higher than pre-EHR (66.7\% vs. $62.3 \%)$. 
Table 7

Differences in Proportion of Patients Achieving Recommended Intermediate Outcome Levels at Three Time Points

\begin{tabular}{|c|c|c|c|c|c|}
\hline \multirow{2}{*}{$\begin{array}{l}\text { The Recommended } \\
\text { Intermediate Outcome Levels }\end{array}$} & Pre-EHR & $\begin{array}{l}\text { One Year } \\
\text { Post-EHR }\end{array}$ & $\begin{array}{c}\text { Two } \\
\text { Years } \\
\text { Post-EHR }\end{array}$ & \multirow{2}{*}{$\begin{array}{c}p \text { value } \\
\text { Pre-EHR } \\
\text { vs. One } \\
\text { Year Post- } \\
\text { EHR }\end{array}$} & \multirow{2}{*}{$\begin{array}{l}p \text { value } \\
\text { Pre-EHR } \\
\text { vs. Two } \\
\text { Years } \\
\text { Post-EHR }\end{array}$} \\
\hline & $n^{\mathrm{a}}(\%)$ & $n^{\mathrm{a}}(\%)$ & $n^{\mathrm{a}}(\%)$ & & \\
\hline \multicolumn{6}{|l|}{ HbA1c levels $\leq 7 \%$} \\
\hline $\begin{array}{l}\text { Pre-EHR vs. One Year Post-EHR, } \\
n^{\mathrm{b}}=1025(100 \%)\end{array}$ & $508(49.6)$ & 409 (39.9) & - & $0.000 *$ & - \\
\hline $\begin{array}{l}\text { Pre-EHR vs. Two Years Post-EHR, } \\
n^{\mathrm{b}}=988(100 \%)\end{array}$ & $493(49.9)$ & - & $384(38.9)$ & - & $0.000 *$ \\
\hline \multicolumn{6}{|l|}{ SBP levels $<140 \mathrm{mmHg}$} \\
\hline $\begin{array}{l}\text { Pre-EHR vs. One Year Post-EHR, } \\
n^{\mathrm{b}}=640(100 \%)\end{array}$ & $500(78.1)$ & $470(73.4)$ & - & $0.023 *$ & - \\
\hline $\begin{array}{l}\text { Pre-EHR vs. Two Years Post-EHR, } \\
n^{\mathrm{b}}=652(100 \%)\end{array}$ & $508(77.9)$ & - & $484(74.3)$ & & 0.079 \\
\hline \multicolumn{6}{|l|}{ DBP levels $<80 \mathrm{mmHg}$} \\
\hline $\begin{array}{l}\text { Pre-EHR vs. One Year Post-EHR, } \\
n^{\mathrm{b}}=640(100 \%)\end{array}$ & $501(78.3)$ & $501(78.3)$ & - & 1.000 & - \\
\hline $\begin{array}{l}\text { Pre-EHR vs. Two Years Post-EHR, } \\
n^{\mathrm{b}}=652(100 \%)\end{array}$ & $510(78.2)$ & - & $501(76.8)$ & & 0.541 \\
\hline \multicolumn{6}{|l|}{ Total cholesterol levels $<170 \mathrm{mg} / \mathrm{dL}$} \\
\hline $\begin{array}{l}\text { Pre-EHR vs. One Year Post-EHR, } \\
n^{\mathrm{b}}=826(100 \%)\end{array}$ & $515(62.3)$ & $522(63.2)$ & - & 0.699 & - \\
\hline $\begin{array}{l}\text { Pre-EHR vs. Two Years Post-EHR, } \\
n^{\mathrm{b}}=818(100 \%)\end{array}$ & $510(62.3)$ & - & $546(66.7)$ & - & $0.023 *$ \\
\hline \multicolumn{6}{|l|}{ HDL-C levels $>45 \mathrm{mg} / \mathrm{dL}$} \\
\hline $\begin{array}{l}\text { Pre-EHR vs. One Year Post-EHR, } \\
n^{\mathrm{b}}=818(100 \%)\end{array}$ & $287(35.1)$ & $273(33.4)$ & - & 0.275 & - \\
\hline $\begin{array}{l}\text { Pre-EHR vs. Two Years Post-EHR, } \\
n^{\mathrm{b}}=815(100 \%)\end{array}$ & $291(35.7)$ & - & $273(33.5)$ & - & 0.165 \\
\hline \multicolumn{6}{|l|}{ LDL-C levels $<100 \mathrm{mg} / \mathrm{dL}$} \\
\hline $\begin{array}{l}\text { Pre-EHR vs. One Year Post-EHR, } \\
n^{\mathrm{b}}=792(100 \%)\end{array}$ & $511(64.5)$ & $520(65.7)$ & & 0.592 & \\
\hline $\begin{array}{l}\text { Pre-EHR vs. Two Years Post-EHR, } \\
n^{\mathrm{b}}=786(100 \%)\end{array}$ & $514(65.4)$ & - & $521(66.3)$ & - & 0.688 \\
\hline \multicolumn{6}{|l|}{ Triglycerides levels $<150 \mathrm{mg} / \mathrm{dL}$} \\
\hline $\begin{array}{l}\text { Pre-EHR vs. One Year Post-EHR, } \\
n^{\mathrm{b}}=818(100 \%)\end{array}$ & $467(57.1)$ & $471(57.6)$ & & 0.838 & \\
\hline $\begin{array}{l}\text { Pre-EHR vs. Two Years Post-EHR, } \\
n^{\mathrm{b}}=815(100 \%)\end{array}$ & $475(58.3)$ & - & 488 (59.9) & - & 0.428 \\
\hline
\end{tabular}

Note. $n^{\mathrm{a}}=$ Number of patients achieving the recommended intermediate outcome levels; $n^{\mathrm{b}}=$ Number of patients who had intermediate outcome measures documented in two time point comparisons; ${ }^{*} p=0.05$ from McNemar's tests. 
Table 8 presents the mean differences in intermediate outcome levels of the same patients diagnosed with type 2 diabetes between pre-EHR and one year post-EHR, and between pre-EHR and two years post-EHR. The first significant difference was found in HbA1c levels from pre-EHR to one year post-EHR, and from pre-EHR to two years postEHR. The HbA1c level one year post-EHR $(M=7.7, S D=1.6)$ was significantly higher than pre-EHR $(M=7.4, S D=1.4)$. Similarly, the HbA1c level two years post-EHR $(M=$ $7.8, S D=1.6)$ was significantly higher than pre-EHR $(M=7.4, S D=1.5)$.

A second significant difference also emerged in SBP and DBP levels from preEHR to one year post-EHR, and from pre-EHR to two years post-EHR. The SBP and DBP levels one year post-EHR were found to be significantly higher than pre-EHR $(M=$ $131.9, S D=14.5$ vs. $M=129.3, S D=14.2$ and $M=73.1, S D=9$ vs. $M=72.4, S D=9.1$, accordingly). Likewise, the SBP and DBP levels two years post-EHR were significantly higher than pre-EHR $(M=131.6, S D=13.6$ vs. $M=129.3, S D=14.2$ and $M=73.1, S D$ $=8.9$ vs. $M=72.3, S D=9$, accordingly).

The last significant difference was found in HDL-C levels from pre-EHR to one year post-EHR, and from pre-EHR to two years post-EHR. The HDL level one year post$\operatorname{EHR}(M=42.2, S D=11.4)$ was significantly lower than pre-EHR $(M=42.8, S D=10.9)$. Similarly, the HDL level two years post-EHR $(M=42.3, S D=11.3)$ was significantly lower than pre-EHR $(M=43, S D=11.1)$. 
Table 8

Mean Differences in Intermediate Outcome Levels for Patients Diagnosed with Type 2 Diabetes at Three Time Points

\begin{tabular}{|c|c|c|c|c|c|c|c|}
\hline \multirow{2}{*}{$\begin{array}{c}\text { Intermediate Outcome } \\
\text { Measures }\end{array}$} & \multicolumn{2}{|c|}{ Pre-EHR } & \multicolumn{2}{|c|}{ One Year Post-EHR } & \multicolumn{2}{|c|}{$\begin{array}{c}\text { Two Years Post- } \\
\text { EHR }\end{array}$} & \multirow{2}{*}{$p$} \\
\hline & $n^{\mathrm{a}}(\%)$ & $M(S D)$ & $n^{\mathrm{a}}(\%)$ & $M(S D)$ & $\mathrm{n}^{\mathrm{a}}(\%)$ & $M(S D)$ & \\
\hline \multicolumn{8}{|l|}{$\begin{array}{l}\text { The most recent HbA1c } \\
\text { value }(\%)\end{array}$} \\
\hline $\begin{array}{l}\text { Pre-EHR vs. One } \\
\text { Year Post-EHR }\end{array}$ & $\begin{array}{l}1,025 \\
(100) \\
\end{array}$ & $7.4(1.4)$ & $\begin{array}{l}1,025 \\
(100) \\
\end{array}$ & $7.7(1.6)$ & - & - & $\begin{array}{r}\mathbf{0 . 0 0 0} \\
*\end{array}$ \\
\hline $\begin{array}{l}\text { Pre-EHR vs. Two } \\
\text { Years Post-EHR }\end{array}$ & $\begin{array}{r}988 \\
(100)\end{array}$ & $7.4(1.5)$ & 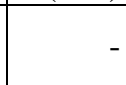 & & $\begin{array}{r}988 \\
(100)\end{array}$ & $7.8(1.6)$ & $\begin{array}{r}\mathbf{0 . 0 0 0} \\
*\end{array}$ \\
\hline \multicolumn{8}{|l|}{$\begin{array}{l}\text { Mean of the last three } \\
\text { SBP values (mmHg) }\end{array}$} \\
\hline $\begin{array}{l}\text { Pre-EHR vs. One } \\
\text { Year Post-EHR }\end{array}$ & $\begin{array}{r}640 \\
(100) \\
\end{array}$ & $\begin{array}{r}129.3 \\
(14.2) \\
\end{array}$ & $\begin{array}{r}640 \\
(100) \\
\end{array}$ & $\begin{array}{r}131.9 \\
(14.5) \\
\end{array}$ & - & - & $\begin{array}{r}0.000 \\
*\end{array}$ \\
\hline $\begin{array}{l}\text { Pre-EHR vs. Two } \\
\text { Years Post-EHR }\end{array}$ & $\begin{array}{r}652 \\
(100)\end{array}$ & $\begin{array}{r}129.3 \\
(14.2)\end{array}$ & & & $\begin{array}{r}652 \\
(100)\end{array}$ & $\begin{aligned} 131.6 \\
(13.6)\end{aligned}$ & $\begin{array}{r}0.000 \\
*\end{array}$ \\
\hline \multicolumn{8}{|l|}{$\begin{array}{l}\text { Mean of the last three } \\
\text { DBP values }\end{array}$} \\
\hline $\begin{array}{l}\text { Pre-EHR vs. One } \\
\text { Year Post-EHR }\end{array}$ & $\begin{array}{r}640 \\
(100) \\
\end{array}$ & $\begin{array}{l}72.4 \\
(9.1)\end{array}$ & $\begin{array}{r}640 \\
(100) \\
\end{array}$ & $73.1(9)$ & - & - & $\begin{array}{r}0.036 \\
*\end{array}$ \\
\hline $\begin{array}{l}\text { Pre-EHR vs. Two } \\
\text { Years Post-EHR }\end{array}$ & $\begin{array}{r}652 \\
(100) \\
\end{array}$ & $72.3(9)$ & - & - & $\begin{array}{r}652 \\
(100)\end{array}$ & $\begin{array}{l}73.1 \\
(8.9) \\
\end{array}$ & $\begin{array}{r}0.016 \\
*\end{array}$ \\
\hline \multicolumn{8}{|l|}{$\begin{array}{l}\text { The most recent Total } \\
\text { cholesterol value } \\
(\mathrm{mg} / \mathrm{dL})\end{array}$} \\
\hline $\begin{array}{l}\text { Pre-EHR vs. One } \\
\text { Year Post-EHR }\end{array}$ & $\begin{array}{r}826 \\
(100) \\
\end{array}$ & $\begin{array}{l}163.6 \\
(37.3)\end{array}$ & $\begin{array}{r}826 \\
(100) \\
\end{array}$ & $\begin{array}{l}162.8 \\
(40.1)\end{array}$ & $\begin{array}{lll}- & \text { r }\end{array}$ & - & 0.550 \\
\hline $\begin{array}{l}\text { Pre-EHR vs. Two } \\
\text { Years Post-EHR }\end{array}$ & $\begin{array}{r}818 \\
(100)\end{array}$ & $\begin{aligned} 163.8 \\
(37.9)\end{aligned}$ & - & - & $\begin{array}{r}818 \\
(100)\end{array}$ & $\begin{aligned} 161.4 \\
(39.5)\end{aligned}$ & 0.069 \\
\hline \multicolumn{8}{|l|}{$\begin{array}{l}\text { The most recent HDL-C } \\
\text { value }(\mathrm{mg} / \mathrm{dL})\end{array}$} \\
\hline $\begin{array}{l}\text { Pre-EHR vs. One } \\
\text { Year Post-EHR }\end{array}$ & $\begin{array}{r}818 \\
(100)\end{array}$ & $\begin{array}{r}42.8 \\
(10.9)\end{array}$ & $\begin{array}{r}818 \\
(100)\end{array}$ & $\begin{array}{r}42.2 \\
(11.4)\end{array}$ & - & - & $\begin{array}{r}0.018 \\
*\end{array}$ \\
\hline $\begin{array}{l}\text { Pre-EHR vs. Two } \\
\text { Years Post-EHR }\end{array}$ & $\begin{array}{r}815 \\
(100) \\
\end{array}$ & $\begin{array}{r}43 \\
(11.1) \\
\end{array}$ & - & $\begin{array}{ll}- \\
-\end{array}$ & $\begin{array}{r}815 \\
(100) \\
\end{array}$ & $\begin{array}{r}42.3 \\
(11.3) \\
\end{array}$ & $\begin{array}{r}0.014 \\
*\end{array}$ \\
\hline \multicolumn{8}{|l|}{$\begin{array}{l}\text { The most recent LDL-C } \\
\text { value }(\mathrm{mg} / \mathrm{dL})\end{array}$} \\
\hline $\begin{array}{l}\text { Pre-EHR vs. One } \\
\text { Year Post-EHR }\end{array}$ & $\begin{array}{r}792 \\
(100) \\
\end{array}$ & $\begin{array}{r}94.5 \\
(30.5) \\
\end{array}$ & $\begin{array}{r}792 \\
(100) \\
\end{array}$ & $\begin{array}{r}93.1 \\
(28.9) \\
\end{array}$ & - & - & 0.170 \\
\hline $\begin{array}{l}\text { Pre-EHR vs. Two } \\
\text { Years Post-EHR }\end{array}$ & $\begin{array}{r}786 \\
(100) \\
\end{array}$ & $\begin{array}{l}93.7 \\
(30)\end{array}$ & - & - & $\begin{array}{r}786 \\
(100) \\
\end{array}$ & $\begin{array}{r}92.1 \\
(30.4)\end{array}$ & 0.138 \\
\hline \multicolumn{8}{|l|}{$\begin{array}{l}\text { The most recent } \\
\text { Triglycerides value }\end{array}$} \\
\hline $\begin{array}{l}\text { Pre-EHR vs. One } \\
\text { Year Post-EHR }\end{array}$ & $\begin{array}{r}818 \\
(100)\end{array}$ & $\begin{array}{r}159.9 \\
(97.9)\end{array}$ & $\begin{array}{r}818 \\
(100)\end{array}$ & $\begin{array}{r}160.6 \\
(121.6)\end{array}$ & - & - & 0.845 \\
\hline $\begin{array}{l}\text { Pre-EHR vs. Two } \\
\text { Years Post-EHR }\end{array}$ & $\begin{array}{r}815 \\
(100)\end{array}$ & $\begin{array}{r}160.7 \\
(100.7) \\
\end{array}$ & 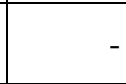 & 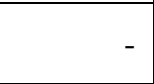 & $\begin{array}{r}815 \\
(100)\end{array}$ & $\begin{array}{r}160.3 \\
(112.3)\end{array}$ & 0.910 \\
\hline
\end{tabular}

Note. $n^{\mathrm{a}}=$ Number of patients who had intermediate outcome measures documented in two time point comparisons; ${ }^{*} p=0.05$ from paired-sample $t$-tests. 


\section{Multiple Regressions}

Multiple regressions were used to examine the effect of patient characteristics, mainly age, sex, race, and type of health insurance, on intermediate outcome levels at one year and two years post-EHR (see Tables 9 and 10).

\section{SBP}

Race and type of health insurance were found to be significant predictors for SBP one year post-EHR. Black patients had $3.390 \mathrm{mmHg}$ higher in SBP levels compared to white patients and patients covered by Medicaid had $5.637 \mathrm{mmHg}$ lower in SBP levels compared to patients covered by private health insurance after controlling for pre-EHR SBP level and patient characteristics. Meanwhile, age and type of health insurance were identified as significant predictors for SBP two years post-EHR. As age increased by 1 year the SBP level increased by $0.113 \mathrm{mmHg}$. Furthermore, uninsured patients were found to have higher SBP levels $(5.135 \mathrm{mmHg})$ than patients covered by private health insurance after controlling for pre-EHR SBP level and patient characteristics.

\section{DBP}

Age, sex, and race were significant predictors for DBP one year post-EHR. As age increased by 1 year the DBP level decreased by $0.142 \mathrm{mmHg}$. Male patients were found to have higher DBP levels $(1.519 \mathrm{mmHg})$ than female patients, and black patients had higher DBP levels $(2.712 \mathrm{mmHg})$ than white patients one year post-EHR, after controlling for pre-EHR DBP level and patient characteristics.

Age and sex were also identified as significant predictors for DBP two years postEHR. As age increased by 1 year the DBP level decreased by $0.132 \mathrm{mmHg}$. Male patients 
had higher DBP levels (1.624 mmHg) than female patients two years post-EHR after adjusting for pre-EHR DBP level and patient characteristics.

HbA1c

One year post-EHR, only the type of health insurance was a significant predictor for HbA1c. Patients covered by Medicaid had $0.433 \%$ higher in HbA1c levels than patients covered by private health insurance one year post-EHR after controlling for preEHR HbA1c level and patient characteristics.

Two years post-EHR, the age and type of health insurance were found to be significant predictors for HbA1c. As age increased by 1 year the HbA1c level decreased by $0.014 \%$. Moreover, patients covered by other types of health insurance had $0.798 \%$ higher in HbA1c levels compared to patients covered by private health insurance two years post-EHR after controlling for pre-EHR HbA1c level and patient characteristics.

\section{Total Cholesterol}

Only age was found to be a significant predictor for total cholesterol one year post-EHR. As age increased by 1 year, total cholesterol level decreased by $0.345 \mathrm{mg} / \mathrm{dL}$ one year post-EHR after controlling for pre-EHR total cholesterol level and patient characteristics.

Two years post-EHR, age and type of health insurance were identified as significant predictors for total cholesterol. As age increased by 1 year, total cholesterol decreased by $0.603 \mathrm{mg} / \mathrm{dL}$. Additionally, patients covered by other types of health insurance had higher total cholesterol $(16.737 \mathrm{mg} / \mathrm{dL})$ than patients covered by private health insurance in two years post-EHR after adjusting for pre-EHR total cholesterol level and patient characteristics. 


\section{HDL-C}

Sex was a significant predictor for HDL-C one year and two years post-EHR. Male patients had $1.415 \mathrm{mg} / \mathrm{dL}$ lower in HDL-C levels one year post-EHR and 1.075 mg/dL lower in HDL-C levels two years post EHR compared to female patients after controlling for pre-EHR HDL-C level and patient characteristics.

\section{$L D L-C$}

One year post-EHR, only race was identified as a significant predictor for LDL-C. Black patients were found to have higher LDL-C levels (4.947 mg/dL) than white patients after controlling for pre-EHR LDL-C level and patient characteristics. Two years post-EHR, only age was found as a significant predictor for LDL-C. As age increased by 1 year, LDL-C level decreased by $0.323 \mathrm{mg} / \mathrm{dL}$ after adjusting for pre-EHR LDL-C level and patient characteristics.

\section{Triglycerides}

Age and race were found to be significant predictors for triglycerides one year and two years post-EHR. As age increased by 1 year the triglycerides level decreased by $1.015 \mathrm{mg} / \mathrm{dL}$ one year post-EHR and $1.337 \mathrm{mg} / \mathrm{dL}$ two years post-EHR. Moreover, black patients were found to have lower triglycerides levels one year post-EHR $(24.159 \mathrm{mg} / \mathrm{dL})$ and two years post-EHR (34.832 mg/dL) after controlling for pre-EHR triglycerides level and patient characteristics. 
Table 9

The Effect of Patient Characteristics on Intermediate Outcome Levels at One Year Post-EHR

\begin{tabular}{|c|c|c|c|c|c|c|c|c|c|c|c|c|c|c|}
\hline \multirow{3}{*}{ Covariates } & \multicolumn{14}{|c|}{ One Year Post-EHR } \\
\hline & \multicolumn{2}{|c|}{ SBP } & \multicolumn{2}{|c|}{ DBP } & \multicolumn{2}{|c|}{ HbAlc } & \multicolumn{2}{|c|}{$\begin{array}{c}\text { Total } \\
\text { Cholesterol }\end{array}$} & \multicolumn{2}{|c|}{ HDL-C } & \multicolumn{2}{|c|}{ LDL-C } & \multicolumn{2}{|c|}{ Triglycerides } \\
\hline & $b(S E)$ & $p$ & $b(S E)$ & $p$ & $b(S E)$ & $p$ & $b(S E)$ & $p$ & $b(S E)$ & $p$ & $b(S E)$ & $p$ & $b(S E)$ & $P$ \\
\hline Age & $\begin{array}{r}.100 \\
(.057) \\
\end{array}$ & .083 & $\begin{array}{r}\mathbf{- . 1 4 2} \\
(.033) \\
\end{array}$ & $.000 *$ & $\begin{array}{r}-.001 \\
(.005) \\
\end{array}$ & .825 & $\begin{array}{r}-.345 \\
(.147) \\
\end{array}$ & $.019 *$ & $\begin{array}{r}.000 \\
(.029) \\
\end{array}$ & 998 & $\begin{array}{r}-.141 \\
(.108) \\
\end{array}$ & .192 & $\begin{array}{r}\mathbf{- 1 . 0 1 5} \\
(.461) \\
\end{array}$ & $.028 *$ \\
\hline Sex & & & & & & & & & & & & & & \\
\hline Male $^{\mathrm{a}}$ & $\begin{array}{r}1.256 \\
(1.019)\end{array}$ & .218 & $\begin{array}{l}\mathbf{1 . 5 1 9} \\
(.586)\end{array}$ & $.010 *$ & $\begin{array}{l}. .051 \\
(.081)\end{array}$ & .534 & $\begin{array}{l}-1.938 \\
(2.454)\end{array}$ & 430 & $\begin{array}{r}\mathbf{- 1 . 4 1 5} \\
(.480)\end{array}$ & $.003 *$ & $\begin{array}{l}-1.043 \\
(1.784)\end{array}$ & .559 & $\begin{array}{r}-.847 \\
(7.475)\end{array}$ & .910 \\
\hline Race & & & & & & & & & & & & & & \\
\hline Black $^{b}$ & $\begin{array}{r}\mathbf{3 . 3 9 0} \\
(1.109) \\
\end{array}$ & $.002 *$ & $\begin{array}{l}\mathbf{2 . 7 1 2} \\
(.634) \\
\end{array}$ & $.000 *$ & $\begin{array}{r}.096 \\
(.095) \\
\end{array}$ & .312 & $\begin{array}{r}3.440 \\
(2.772) \\
\end{array}$ & 215 & $\begin{array}{r}.970 \\
(.544) \\
\end{array}$ & .075 & $\begin{array}{r}4.947 \\
(2.041) \\
\end{array}$ & $.016^{*}$ & $\begin{array}{r}\mathbf{- 2 4 . 1 5 9} \\
(8.820) \\
\end{array}$ & $.006 *$ \\
\hline Others $^{b}$ & $\begin{array}{r}-.185 \\
(2.427) \\
\end{array}$ & .939 & $\begin{array}{r}-.346 \\
(1.377)\end{array}$ & .802 & $\begin{array}{r}-.058 \\
(.187)\end{array}$ & .757 & $\begin{array}{r}-3.450 \\
(5.251)\end{array}$ & .511 & $\begin{array}{r}-.687 \\
(1.018) \\
\end{array}$ & .500 & $\begin{array}{r}1.035 \\
(3.807) \\
\end{array}$ & .786 & $\begin{array}{r}-12.392 \\
(16.341)\end{array}$ & .448 \\
\hline $\begin{array}{l}\text { Type of } \\
\text { Health } \\
\text { Insurance }\end{array}$ & & & & & & & & & & & & & & \\
\hline Medicare $^{c}$ & $\begin{array}{r}-.656 \\
(1.267)\end{array}$ & .605 & $\begin{array}{r}.466 \\
(.720) \\
\end{array}$ & .517 & $\begin{array}{l}-.067 \\
(.101)\end{array}$ & .503 & $\begin{array}{r}1.017 \\
(2.961)\end{array}$ & .731 & $\begin{array}{l}-.488 \\
(.579)\end{array}$ & .400 & $\begin{array}{r}1.145 \\
(2.177)\end{array}$ & .599 & $\begin{array}{r}.965 \\
(9.292)\end{array}$ & .917 \\
\hline Medicaid $^{c}$ & $\begin{array}{r}\mathbf{- 5 . 6 3 7} \\
(2.387) \\
\end{array}$ & $.019 *$ & $\begin{array}{r}-.956 \\
(1.353) \\
\end{array}$ & 480 & $\begin{array}{r}. \mathbf{4 3 3} \\
(.189) \\
\end{array}$ & $.022 *$ & $\begin{array}{r}-8.925 \\
(5.662) \\
\end{array}$ & 115 & $\begin{array}{r}-1.322 \\
(1.098)\end{array}$ & .229 & $\begin{array}{r}-2.530 \\
(4.079)\end{array}$ & .535 & $\begin{array}{r}-15.828 \\
(17.644) \\
\end{array}$ & .370 \\
\hline Uninsured $^{c}$ & $\begin{array}{r}-1.302 \\
(1.513) \\
\end{array}$ & .390 & $\begin{array}{r}.013 \\
(.856) \\
\end{array}$ & .987 & $\begin{array}{r}.145 \\
(.131) \\
\end{array}$ & .267 & $\begin{array}{r}-6.405 \\
(3.947) \\
\end{array}$ & .105 & $\begin{array}{r}-.832 \\
(.767) \\
\end{array}$ & .278 & $\begin{array}{r}-3.073 \\
(2.907) \\
\end{array}$ & .291 & $\begin{array}{r}-21.492 \\
(12.390) \\
\end{array}$ & .083 \\
\hline Other ${ }^{\mathrm{c}}$ & $\begin{array}{r}-3.353 \\
(4.859)\end{array}$ & 490 & $\begin{array}{r}2.331 \\
(2.763)\end{array}$ & .399 & $\begin{array}{r}.415 \\
(.319)\end{array}$ & 193 & $\begin{array}{r}-1.591 \\
(8.472)\end{array}$ & .851 & $\begin{array}{r}1.471 \\
(1.641)\end{array}$ & .370 & $\begin{array}{r}-2.743 \\
(6.269)\end{array}$ & .662 & $\begin{array}{r}-6.155 \\
(26.387)\end{array}$ & .816 \\
\hline
\end{tabular}

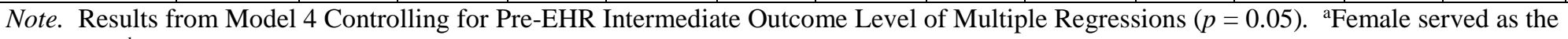
reference. ${ }^{b}$ White race served as the reference. ${ }^{\text {PPrivate }}$ health insurance served as the reference. 
Table 10

The Effect of Patient Characteristics on Intermediate Outcome Levels at Two Years Post-EHR

\begin{tabular}{|c|c|c|c|c|c|c|c|c|c|c|c|c|c|c|}
\hline \multirow{3}{*}{ Covariates } & \multicolumn{14}{|c|}{ Two Years Post-EHR } \\
\hline & \multicolumn{2}{|c|}{ SBP } & \multicolumn{2}{|c|}{ DBP } & \multicolumn{2}{|c|}{$\mathrm{HbA1c}$} & \multicolumn{2}{|c|}{ Total Cholesterol } & \multicolumn{2}{|c|}{ HDL-C } & \multicolumn{2}{|c|}{ LDL-C } & \multicolumn{2}{|c|}{ Triglycerides } \\
\hline & $b(S E)$ & $p$ & $b(S E)$ & $p$ & $b(S E)$ & $p$ & $b(S E)$ & $p$ & $b(S E)$ & $p$ & $b(S E)$ & $p$ & $b(S E)$ & $p$ \\
\hline Age & $\begin{array}{r}\mathbf{1 1 3} \\
(.055) \\
\end{array}$ & $.040 *$ & $\begin{array}{r}-.132 \\
(.034)\end{array}$ & $.000 *$ & $\begin{array}{r}-.014 \\
(.005)\end{array}$ & $.006 *$ & $\begin{array}{r}-.603 \\
(.144) \\
\end{array}$ & $.000^{*}$ & $\begin{array}{r}-.033 \\
(.031) \\
\end{array}$ & .287 & $\begin{array}{r}-. .323 \\
(.119) \\
\end{array}$ & $.007 *$ & $\begin{array}{r}\mathbf{- 1 . 3 3 7} \\
(.431) \\
\end{array}$ & $.002 *$ \\
\hline Sex & & & & & & & & & & & & & & \\
\hline Male $^{\mathrm{a}}$ & $\begin{array}{r}.338 \\
(.970)\end{array}$ & .728 & $\begin{array}{l}\mathbf{1 . 6 2 4} \\
(.597)\end{array}$ & $.007 *$ & $\begin{array}{l}-.087 \\
(.087)\end{array}$ & .317 & $\begin{array}{l}-4.004 \\
(2.375)\end{array}$ & .092 & $\begin{array}{r}\mathbf{- 1 . 0 7 5} \\
(.516)\end{array}$ & $.037^{*}$ & $\begin{array}{l}-1.787 \\
(1.905)\end{array}$ & .349 & $\begin{array}{l}-6.813 \\
(6.992)\end{array}$ & .330 \\
\hline Race & & & & & & & & & & & & & & \\
\hline Black $^{b}$ & $\begin{array}{r}1.897 \\
(1.052)\end{array}$ & .072 & $\begin{array}{r}.761 \\
(.646) \\
\end{array}$ & .239 & $\begin{array}{r}.011 \\
(.102) \\
\end{array}$ & 916 & $\begin{array}{l}-1.956 \\
(2.789)\end{array}$ & .483 & $\begin{array}{r}.046 \\
(.601)\end{array}$ & .939 & $\begin{array}{r}3.624 \\
(2.263)\end{array}$ & .110 & $\begin{array}{r}\mathbf{- 3 4 . 8 3 2} \\
(8.498) \\
\end{array}$ & $.000 *$ \\
\hline Others $^{b}$ & $\begin{array}{l}-1.177 \\
(2.348) \\
\end{array}$ & .616 & $\begin{array}{r}-1.642 \\
(1.427) \\
\end{array}$ & .250 & $\begin{array}{r}.057 \\
(.199) \\
\end{array}$ & .776 & $\begin{array}{r}-7.540 \\
(4.993) \\
\end{array}$ & .131 & $\begin{array}{r}-1.872 \\
(1.066) \\
\end{array}$ & .079 & $\begin{array}{r}-1.526 \\
(4.033) \\
\end{array}$ & .705 & $\begin{array}{c}-15.666 \\
(14.935) \\
\end{array}$ & .295 \\
\hline $\begin{array}{l}\text { Type of } \\
\text { health } \\
\text { insurance }\end{array}$ & & & & & & & & & & & & & & \\
\hline Medicare $^{\mathrm{c}}$ & $\begin{array}{r}.118 \\
(1.201)\end{array}$ & .922 & $\begin{array}{r}.476 \\
(.731) \\
\end{array}$ & .515 & $\begin{array}{r}.104 \\
(.106)\end{array}$ & .324 & $\begin{array}{r}1.955 \\
(2.900)\end{array}$ & .501 & $\begin{array}{l}-.364 \\
(.621)\end{array}$ & .559 & $\begin{array}{r}.218 \\
(2.352)\end{array}$ & .926 & $\begin{array}{c}10.088 \\
(8.706)\end{array}$ & .247 \\
\hline Medicaid $^{c}$ & $\begin{array}{r}.933 \\
(2.184)\end{array}$ & .670 & $\begin{array}{r}-.298 \\
(1.327)\end{array}$ & .822 & $\begin{array}{l}-.111 \\
(.205)\end{array}$ & .590 & $\begin{array}{r}-8.381 \\
(5.483)\end{array}$ & .127 & $\begin{array}{l}-1.036 \\
(1.173)\end{array}$ & .377 & $\begin{array}{r}-4.299 \\
(4.409)\end{array}$ & .330 & $\begin{array}{r}-16.006 \\
(16.437)\end{array}$ & .330 \\
\hline Uninsured $^{\mathrm{c}}$ & $\begin{array}{r}\mathbf{5 . 1 3 5} \\
(1.446) \\
\end{array}$ & $.000 *$ & $\begin{array}{r}1.682 \\
(.877) \\
\end{array}$ & .056 & $\begin{array}{r}.249 \\
(.144) \\
\end{array}$ & .083 & $\begin{array}{r}-5.082 \\
(3.801) \\
\end{array}$ & .182 & $\begin{array}{r}.487 \\
(.814) \\
\end{array}$ & .550 & $\begin{array}{r}-5.867 \\
(3.131) \\
\end{array}$ & .061 & $\begin{array}{r}5.290 \\
(11.499) \\
\end{array}$ & .646 \\
\hline Other ${ }^{\mathrm{c}}$ & $\begin{array}{r}-.953 \\
(4.662) \\
\end{array}$ & .838 & $\begin{array}{r}4.481 \\
(2.841)\end{array}$ & .115 & $\begin{array}{r}.798 \\
(.335)\end{array}$ & $.017 *$ & $\begin{array}{r}\mathbf{1 6 . 7 3 7} \\
(8.199) \\
\end{array}$ & $.042 *$ & $\begin{array}{r}2.247 \\
(1.749) \\
\end{array}$ & .199 & $\begin{array}{r}4.219 \\
(6.898) \\
\end{array}$ & .541 & $\begin{array}{r}39.818 \\
(24.556)\end{array}$ & .105 \\
\hline
\end{tabular}

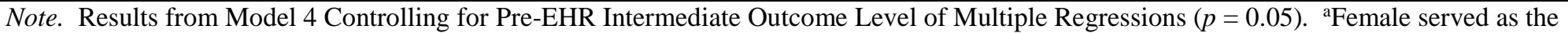
reference. ${ }^{b}$ White race served as the reference. ${ }^{c}$ Private health insurance served as the reference. 


\section{DISCUSSION}

Two major findings emerged in this study: first, the positive changes in the frequency of BP measurements documented and the proportion of patients who had at least one BP measurement documented one year and two years post-EHR (process measures); and second, the proportion of patients achieving total cholesterol level of $<170 \mathrm{mg} / \mathrm{dL}$ two years post-EHR (intermediate outcome measures). Other significant findings were the negative changes in the process measures (frequency of HbAlc and lipid profile tests documented and proportion of patients who had at least one HbAlc test documented two years post-EHR) and in the intermediate outcome measures (proportion of patients achieving the HbA1c level of $\leq 7 \%$ one year and two years post-EHR, proportion of patients achieving the SBP level of $<140 \mathrm{mmHg}$ one year post-EHR, and levels of HbA1c, SBP, DBP, and HDL one year and two years post-EHR).

\section{EHRs and process of diabetes care}

This study found that there was an increase in the frequency of BP measurement documentation and the proportion of patients who had at least one BP measurement documented from pre-EHR to one year and two years post-EHR. Our finding is consistent with previous findings of improvement in BP documentation after EHR implementation..$^{10,14}$

The positive changes in BP measurement and BP documentation over time found in this study might be due to the following reasons. One explanation was that a remarkable increase occurred in EHR being used by office-based physicians, i.e., from 18\% in 2001 to $48 \%$ in 2009 and $78 \%$ in $2013 .{ }^{37}$ This high rate of EHR adoption among office-based physicians was favorable as it complied with US regulations in 2009 under 
the HITECH Act that hospitals across the US are expected to adopt EHRs and become the EHR meaningful users by $2014 .{ }^{54}$ One of the core objectives for meaningful use is recording and charting of vital signs. The CMS will provide incentive payments to eligible professionals and hospitals in return for their becoming meaningful users of EHRs between 2009 and 2014. ${ }^{55-56}$ However, if eligible professionals and hospitals do not adopt and successfully demonstrate meaningful use of EHRs by 2015, the CMS will apply financial penalties to them. ${ }^{55,57-58}$ Therefore, the study's main finding of an increase in BP documentation is important for showing that these practices met one objective of EHR meaningful use criteria. ${ }^{57-58}$ In Stage 2, there are 19 MU objectives to be met in order to qualify for the CMS incentive payments. ${ }^{57-58}$ The other MU objectives for Stage 2 include recording patient demographics, recording smoking status, incorporating clinical lab-test results into certified EHR technology as structured data, and using clinical decision support systems to improve performance on high-priority health conditions. ${ }^{57-58}$ If other MU objectives for Stage 2 are also achieved, the healthcare system and eligible professionals will receive financial incentives. ${ }^{57-58}$

The improvement in the frequency of BP control documentation and the proportion of patients who had at least one BP control documented after EHR adoption might also be affected by the type of practice (i.e., primary care practices vs. specialty care practices). In our study we found that among patients who had BP measurements documented in the EHR system, $72 \%$ of them visited primary care practices (family medicine and internal medicine) while the remaining patients visited the specialty care (cardiology, diabetes services, and endocrinology). This result was consistent with the result of the study conducted by Wright et al. who found that scores in recording vital 
signs were significantly higher in primary care physicians than in specialists. ${ }^{59}$ However, Wright et al. did not explain the causes of this discrepancy. ${ }^{59}$ In our study, all practices used EHRs and thus, both practices were expected to demonstrate similar performance in charting and recording vital signs. However, as mentioned previously, our study indicated different results in BP documentation between the two practices. Hence, further studies are needed to investigate what factors cause these discrepancies.

Other significant findings in the process of diabetes care were a decline in the frequency of HbA1c and lipid profile tests documented and a drop in the proportion of patients who had at least one HbA1c test documented from pre-EHR to two years postEHR. There are a couple of possible explanations for these negative results, and the data does not provide information on either. The first reason is that the most recent results of HbA1c and lipid profile were at treatment goal, and thus no new HbA1c and lipid profile tests were needed. The second reason is that patients declined the HbAlc and lipid profile tests offered by the physician. Therefore, no documentation of these tests was made. The negative result in $\mathrm{HbA} 1 \mathrm{c}$ was similar to the result found in previous research conducted by Herrin et al., who also discovered that there was a significant decline in the HbA1c measurement after EHR implementation. ${ }^{14}$

\section{EHRs and intermediate outcomes of diabetes care}

This study found that there was a significant improvement in the proportion of patients achieving the recommended total cholesterol level of $<170 \mathrm{mg} / \mathrm{dL}$ two years after EHR implementation. Although an EHR system is not a disease-specific intervention, it may contribute to facilitating the health care provider to prescribe and ensure their patients receive the right medication and education through its important functionalities. 
The EHR functionalities that can be used to monitor patients with high lipid profile levels are laboratory reports under the tests and imaging results, medication orders under the computerized provider order entry and medication lists under the clinical documentation. Furthermore, the positive result found in the lipid profile was probably due to the effect of other factors, such as the lipid-lowering therapy (e.g., Statins), lifestyle modification (diet and exercise), and diabetes education related to the management of diabetic dyslipidemia. ${ }^{60}$ However, this study also found that there was a significant decrease in HDL-C levels one year and two years post-EHR, from $42.8 \mathrm{mg} / \mathrm{dL}$ pre-EHR to 42.2 $\mathrm{mg} / \mathrm{dL}$ one year post-EHR and from $43 \mathrm{mg} / \mathrm{dL}$ pre-EHR to $42.3 \mathrm{mg} / \mathrm{dL}$ two years postEHR. Despite a statistically significant decrease found in the HDL-C level, this result is not clinically significant. It would be clinically significant if the drop were $\geq 1 \mathrm{mg} / \mathrm{dL}$ because every decrease of $1 \mathrm{mg} / \mathrm{dL}$ in HDL-C may be associated with an increase of 2$3 \%$ in the risk of CHD. ${ }^{60}$ Even so, further exploration of confounding factors that may influence the HDL-C level should be conducted in order to discover which confounder could be controlled to increase the HDL-C level.

This study also found a decline in the proportion of patients achieving the recommended $\mathrm{HbA} 1 \mathrm{c}$ level of $\leq 7 \%$ and an increase in HbA1c levels from pre-EHR to one year post-EHR and two years post-EHR. This finding was consistent with the study conducted by Herrin et al. who also found a decrease in achieving the recommended HbA1c level after EHR had been adopted. ${ }^{14}$ That fewer patients achieved the recommended HbA1c level after EHR implementation was probably due to patients' comorbidity and non-adherence to pharmacological therapy (e.g., Metformin), diet and exercise. ${ }^{23}$ Future studies to investigate confounding factors that can affect the HbA1c 
level of these studied patients are needed. Knowing the confounding factor that can produce changes in HbA1c levels will help clinicians to control the confounder in order to lower the $\mathrm{HbA1c}$ level. Decreasing the HbA1c level is important because even a $1 \%$ reduction will reduce the risk of developing eye, kidney, and nerve disease by $40 \%$ while the risk of heart attack will fall by $14 \% .{ }^{61}$

The other significant finding of this study was a decline in the proportion of patients achieving the recommended SBP level of less than $140 \mathrm{mmHg}$ one year postEHR and an increase in SBP and DBP levels one year and two years post-EHR. This finding was consistent with Crosson et al. who also explained that EHR use was not related to reaching recommended BP levels. ${ }^{18}$ In our study, factors that might be associated with the increase in patient SBP levels after EHR implementation were patients' age, disease/comorbidity, lifestyle, and non-adherence to antihypertensive medications. $^{62}$

Finally, as described in the multiple regressions where no consistent pattern was found regarding patient characteristics' effect on intermediate outcome levels one year and two years post-EHR, the findings from this study do lead to some suggestions. One suggestion is that it is essential to include risk adjustment and other confounding factors in the study, particularly patient adherence to the diabetes treatment to prevent further complications, quality of life, and patient satisfaction with the diabetes management.

\section{Patient characteristics}

As shown in Table $3,33.1 \%$ of the patients were aged 65 years or older, but 43.3\% of the patients were covered by Medicare. This is because Medicare is not only for people older than 65 years, but also for people younger than 65 years, those diagnosed 
with end-stage renal disease (ESRD) and the disabled (CMS, 2012). Our sample therefore included sick younger people covered by Medicare.

\section{Study limitations}

Three limitations are identified in our study: requirement for a comprehensive EHR system, sample, and study design. For the first limitation, the full EHR measure designed to improve diabetes care quality had not been implemented yet. The three EHR components are clinical decision support system, best practice alerts, and disease management registries. These three EHR components are important for managing patients with chronic diseases including diabetes.

The second limitation relates to the study sample. As only adult patients diagnosed with type 2 diabetes were included and only outpatient departments with 3year EHR experience located in one teaching hospital were examined, our conclusions may not be applicable to populations with other characteristics in other geographic locations and at other facilities.

The third limitation of this study was related to the study design. As explained in the result section above, only $55 \%$ of 1,201 patients had BP values recorded pre-EHR despite the fact that they all made visits to the outpatient services. However, since this study was a secondary data analysis with no observation of the process of care, we cannot explain the definite causal factors that led to positive and negative results found in this study. Some factors that might have caused the lower proportion of patients that had at least one BP measurement documented in pre-EHR than in the post-EHR are 1) no BP measurement was performed; 2) a BP measurement was performed but not documented (possibly missing); or 3) a BP measurement was performed and documented in an 
outpatient data source but not retained in the scanned document pre-EHR, i.e., a paperbased record, which the institution used before EHR implementation. However, there were only about 15 patients who did not have BP measurements scanned and placed in the EpicCare system pre-EHR.

\section{Implications for nursing and health services}

This study has some implications for clinical practice, nursing research, and health policy. For clinical practice, the results of this study confirm that EHR use improves the process of diabetes care for the same patients diagnosed with type 2 diabetes, particularly for BP measurement and BP documentation. Our results suggest changes in clinical staff and patient behavior based on better data recorded at the point of care can lead to better patient outcomes. Hence, the study results can be used as evidence for hospital administrators when they consider adoption of EHRs.

For nursing research, findings from this study suggest that future studies examining the effect of clinical decision support system or best practice alerts, or disease management registries on quality of diabetes care are needed. Furthermore, future studies with more comprehensive data on diabetes care and outcomes are needed to evaluate the confounding factors that may affect the documentation of diabetes care and the results of the care process (or outcomes) after the implementation of the EHR.

For health policy, the chart reviews to obtain BP values pre-EHR revealed that only two of the three main elements of nursing minimum data sets (NMDS) are included in the EHR system. ${ }^{63}$ The two main elements were client elements and service provider elements. Unfortunately, nursing care elements, including nursing diagnosis, nursing intervention, nursing outcome, and nursing intensity are not included in the current EHR 
system. In fact, these nursing care elements are important for nurses and nurse practitioners who work as care coordinators to evaluate the quality of diabetes care through the EHR system. In particular, it is important to coordinate care with other clinicians and to provide health education for patients diagnosed with type 2 diabetes. Therefore, this study recommends that hospital administrators add nursing care elements as part of the NMDS to their EHRs.

\section{CONCLUSION}

Quality of diabetes care for the same patients diagnosed with type 2 diabetes who visited the same health system differed before and after EHR implementation. Process of diabetes care, mainly BP reading and BP recording, improved significantly after EHR implementation. One of the contributing factors was the effort of the hospital and the clinicians to meet the EHR meaningful use criteria in order to qualify for financial incentives from the CMS. Recording vital signs is one of these criteria. A statistically significant improvement in the proportion of patients achieving the total cholesterol $<170$ $\mathrm{mg} / \mathrm{dL}$ was also evident two years post-EHR. Unpredictably, patients were less likely to achieve $\mathrm{HbA} 1 \mathrm{c}$ level $\leq 7 \%$ and SBP level $<140 \mathrm{mmHg}$ post-EHR. Patient age, comorbidity, and life styles were other factors that might cause these negative findings. Future studies to examine the effect of other EHR comprehensive components, such as best practice alerts, disease management registries, or clinical decision support system on quality of diabetes care are recommended. Suggestions for hospital administrators to consider EHR adoption and to add nursing care elements into their EHRs are also offered by this study. 


\section{REFERENCES}

1. National diabetes fact sheet: National estimates and general information on diabetes and prediabetes in the United States, 2011. The Centers for Disease Control and Prevention (CDC) Website. http://www.cdc.gov/diabetes/pubs/pdf/ndfs_2011.pdf Published May 2011. Accessed September 19, 2012.

2. Diabetes data \& trends. The Centers for Disease Control and Prevention (CDC) Web site. http://www.cdc.gov/diabetes/statistics/prevalence_national.htm. Published November 2013. Accessed December 1, 2013.

3. American Diabetes Association. Economic costs of diabetes in the U.S. in 2012. Diabetes Care. 2013;36(4):1033-1046.

4. United Health Group. The United States of Diabetes: Challenges and Opportunities in the Decade Ahead. Minnesota: United Health Group; 2010.

5. Institute of Medicine. Crossing the Quality Chasm: A New Health System for the 21st Century. Washington, D.C.: National Academy Press; 2001.

6. Shih SC, McCullough CM, Wang JJ, Singer J, Parsons AS. Health information systems in small practices improving the delivery of clinical preventive services. American Journal of Preventive Medicine. 2011;41(6):603-609.

7. Young LA, Potru P. (2011). Diabetes in North Carolina: descriptive epidemiology and meaningful use of electronic health records. $N C$ Med J. 2011;72(5):383-386.

8. DesRoches CM, Painter MW, Jha AK. Health Information Technology in the United States: Better Information Systems for Better Care. Princeton, NJ: Robert Wood Johnson Foundation; 2013. 
9. Meaningful use definition and objectives. In the Health IT.gov Website. http://www.healthit.gov/providers-professionals/meaningful-use-definitionobjectives. Accessed March 9, 2014.

10. Cebul RD, Love TE, Jain AK, Hebert CJ. Electronic health records and quality of diabetes care. N Engl J Med. 2011;365:825-833.

11. Devoe JE, Gold R, McIntire P, Puro J, Chauvie S, Gallia CA. Electronic health records vs Medicaid claims: completeness of diabetes preventive care data in community health centers. Ann Fam Med. 2011;9(4):351-358.

12. Fleurant M, Kell R, Love J, et al. Massachusetts e-health project increased physicians' ability to use registries, and signals progress toward better care. Health Aff (Millwood). 2011;30(7):1256-1264.

13. Friedberg MW, Coltin KL, Safran DG, Dresser M, Zaslavsky AM, Schneider EC. Associations between structural capabilities of primary care practices and performance on selected quality measures. Ann Intern Med. 2009;151(7):456-463.

14. Herrin J, da Graca B, Nicewander D, et al. The effectiveness of implementing an electronic health record on diabetes care and outcomes. Health Services Research. 2012;47(4):1522-1540.

15. Kern LM, Barron Y, Dhopeshwarkar RV, Edwards A, Kaushal R, HITEC Investigators. Electronic health records and ambulatory quality of care. J Gen Intern Med. 2013;28(4):496-503.

16. Linder JA, Schnipper JL, Middleton B. Method of electronic health record documentation and quality of primary care. J Am Med Inform Assoc. 2012;19(6):1019-1024. 
17. Ryan AM, Bishop TF, Shih S, Casalino LP. Small physician practices in New York needed sustained help to realize gains in quality from use of electronic health records. Health Aff (Millwood). 2013;32(1):53-62.

18. Crosson JC, Ohman-Strickland PA, Cohen DJ, Clark EC, Crabtree BF. Typical electronic health record use in primary care practices and the quality of diabetes care. Ann Fam Med. 2012;10(3):221-227.

19. Linmans JJ, Viechtbauer W, Koppenaal T, Spigt M, Knottnerus JA. Using electronic medical records analysis to investigate the effectiveness of lifestyle programs in realworld primary care is challenging: a case study in diabetes mellitus. J Clin Epidemiol. 2012;65(7):785-792.

20. Welch WP, Bazarko D, Ritten K, Burgess Y, Harmon R, Sandy LG. Electronic health records in four community physician practices: impact on quality and cost of care. $J$ Am Med Inform Assoc. 2007;14(3):320-328.

21. Lee PG, Cigolle CT, Blaum, CS. Quality improvement in the diagnosis and management of diabetes mellitus in older adults. Clinical Geriatrics, 2010;18(5):3844.

22. Performance Measurement Set for Adult Diabetes. The National Diabetes Quality Improvement Alliance Web site. http://www.nyqa.org/pdflib/NDQIA\%20Diabetes\%20DomainFinal2005Measures.pdf. Published January 2005. Accessed August 19, 2012.

23. American Diabetes Association. Standards of medical care in diabetes 2013. Diabetes Care. 2013;36(1):S11-S66. 
24. Physician Consortium for Performance Improvement. Measures Development, Methodology, and Oversight Advisory Committee: Recommendations to PCPI Work Groups on Outcome Measures. Chicago: AMA; 2011.

25. Callen J, Paoloni R, Li J, et al. Perceptions of the effect of information and communication technology on the quality of care delivered in emergency departments: a cross-site qualitative study. Annals of Emergency Medicine. $2013 ; 61(2): 131-144$.

26. Carrington JM, Effken JA. Strengths and limitations of the electronic health record for documenting clinical events. CIN: Computers, Informatics, Nursing. $2011 ; 29(6): 360-367$.

27. Carrington JM. The usefulness of nursing languages to communicate a clinical event. CIN: Computers, Informatics, Nursing. 2012;30(2):82-88.

28. Crosson JC, Isaacson N, Lancaster D, Bell DS. Variation in electronic prescribing implementation among twelve ambulatory practices. Journal of General Internal Medicine. 2007;23(4):364-371.

29. Culler SD, Jose J, Kohler S, Rask K. Nurses' perceptions and experiences with the implementation of a medication administration system. CIN: Computers, Informatics, Nursing. 2011;29(5):280-288.

30. Kossman S, Scheidenhelm SL. Nurses' perceptions of the impact of electronic health records on work and patient outcomes. CIN: Computers, Informatics, Nursing. 2008;26(2):69-77. 
31. Rantz MJ, Alexander FG, Galambos C, et al. The use of bedside electronic medical record to improve quality of care in nursing facilities: a qualitative analysis. CIN: Computers, Informatics, Nursing. 2012;30(1):TC3-TC10.

32. Stevenson JE, Nilsson G. Nurses' perceptions of an electronic patient record from a patient safety perspective: a qualitative study. Journal of Advanced Nursing. 2012;68:667-676.

33. Ventres W, Kooienga S, Vuckovic N, Marlin R, Nygren P, Stewart V. Physicians, patients, and the electronic health record: an ethnographic analysis. Annals of Family Medicine. 2006;4:124-131.

34. Whittaker AA, Aufdenkamp M, Tinley S. Barriers and facilitators to electronic documentation in a rural hospital. Journal of Nursing Scholarship. 2009;41:293-300.

35. Yoon-Flannery K, Zandieh SO, Kuperman GJ, Langsam DJ, Hyman D, Kaushal R. A qualitative analysis of an electronic health record (EHR) implementation in an academic ambulatory setting. Informatics in Primary Care. 2008;16:277-284.

36. Zadvinskis IM, Chipps E, Yen P. Exploring nurses' confirmed expectations regarding health IT: A phenomenological study. International Journal of Medical Informatics. 2014;83(2):89-98.

37. Hsiao C-J, Hing E. Use and characteristics of electronic health record systems among office-based physician practices: United States, 2001-2013. NCHS Data Brief, no 143. Hyattsville, MD: National Center for Health Statistics; 2014.

38. Donabedian A. Part 2-some issues in evaluating the quality of nursing care. Am J Public Health Nations Health. 1969;59(10):1833-1836. 
39. Donabedian A. Quality of care: how can it be assessed? JAMA. 1988;260(12):17431748.

40. Ancker JS, Kern LM, Abramson E, Kaushal R. The triangle model for evaluating the effect of health information technology on healthcare quality and safety. J Am Med Inform Assoc. 2012;19(1):61-65.

41. Lyman J. The Clinical Data Repository. Charlottesville: University of Virginia School of Medicine; 2009.

42. Epic Systems Corporation. EpicCare Inpatient. Wisconsin: Epic Systems Corporation; 2010.

43. Elashoff JD. nQuery Advisor Version 5.0 User's Guide. Los Angeles, CA: Microsoft Corporation; 2002.

44. Electronic Health Records. The Healthcare Information and Management Systems Society website. http://www.himss.org/library/ehr/?navItemNumber=13261. Accessed January 23, 2013.

45. What do we mean by "sex" and "gender"? The World Health Organization website. http://www.who.int/gender/whatisgender/en/ Accessed January 14, 2014.

46. Dods RF. Understanding Diabetes: A Biochemical Perspective. Somerset, NJ, USA: Wiley; 2013.

47. Higgins C. Understanding Laboratory Investigations: A Guide for Nurses, Midwives, and Health Professionals. 3rd ed. UK: Wiley-Blackwell; 2012.

48. Dunning T. Care of People with Diabetes: A Manual of Nursing Practice. 4th ed. Australia: Wiley-Blackwell; 2013.

49. Costanzo LS. Physiology. 5th ed. Philadelphia, PA: Saunders; 2014. 
50. Solano MP, Goldberg RB. Lipid management in type 2 diabetes. Clinical Diabetes. 2006;24(1):27-31.

51. Health Information Privacy. The US Department of Health and Human Services website. http://www.hhs.gov/ocr/privacy/hipaa/administrative/privacyrule/index.html. Published August 2002. Accessed September 19, 2012.

52. Meyers LS, Gamst GC, Guarino AJ. Applied Multivariate Research: Design and Interpretation. 2nd ed. California, USA: SAGE Publications, Inc; 2013.

53. Kinnear PR, Gray C. PASW Statistics 17 Made Simple. Psychology Press; 2010.

54. US Department of Health and Human Services (US DHHS). HITECH Act Enforcement Interim Final Rule. Washington D.C.: US DHHS; 2009.

55. Jha AK, DesRoches CM, Kralovec PD, Joshi MS. A progress report on electronic health records in U.S. hospitals. Health Aff (Millwood). 2010;29(10):1951-1957.

56. Flow chart to help eligible professionals (EP) determine eligibility for the Medicare and Medicaid electronic health record (EHR) incentive programs. The Centers for Medicare \& Medicaid Services (CMS) website. http://www.cms.gov/Regulationsand-

Guidance/Legislation/EHRIncentivePrograms/downloads/eligibility_flow_chart.pdf Published September 2010. Accessed January 13, 2014.

57. Meaningful Use. The Centers for Disease Control and Prevention (CDC) website. http://www.cdc.gov/ehrmeaningfuluse/introduction.html. Published October 2012. Accessed October 19, 2012. 
58. Wright A, Feblowitz J, Samal L, McCoy AB, Sittig DF. The Medicare electronic health record incentive program: provider performance on core and menu measures. Health Services Research. 2014;49:325-346.

59. Meaningful Use. The Centers for Medicare and Medicaid Services (CMS) website. https://www.cms.gov/Regulations-andGuidance/Legislation/EHRIncentivePrograms/Meaningful_Use.html. Accessed October 19, 2012.

60. Drexel H. Reducing risk by raising HDL-cholesterol: the evidence. European Heart Journal Supplements. 2006;8(Supplement F):F23-F29.

61. Diabetes HbA1c \{Poor control\}. The U. S. Department of Health and Human Services website. http://www.hrsa.gov/quality/toolbox/508pdfs/diabetesmodule.pdf. Published June 11, 2012. Accessed March 6, 2014.

62. Stults B, Jones R. Management of hypertension in diabetes. Diabetes Spectrum. 2006;19:25-31.

63. Denehy J. Nursing Minimum Data Set for School Nursing Practice: Position Statement. The National Association of School Nurses website. http://www.nasn.org/PolicyAdvocacy/PositionPapersandReports/NASNPositionState mentsFullView/tabid/462/ArticleId/38/Nursing-Minimum-Data-Set-for-SchoolNursing-Practice-Revised-January-2012. Accessed March 6, 2014. 


\section{CHAPTER SIX}

\section{Conclusion}

The purpose of this dissertation was to investigate the association of EHR use on quality of care for patients diagnosed with type 2 diabetes. Since this dissertation utilized a secondary data analysis, two integrative literature reviews were conducted to provide a better basis for and more pertinent information prior to undertaking the main analysis in the third manuscript.

The findings of the qualitative review, 'Nurses' and Other Users' Perceptions of the Effects of Electronic Health Records Implementation on Patient Care," confirm that nurses and other users had more positive than negative perceptions of the effect of EHR use on patient care. Positive perceptions included EHRs' clinical benefits such as facilitated clinical decision-making, enhanced coordination and communication, usability and enhanced clinical information documentation, and improved quality of patient care. Negative perceptions included decreased time at the bedside for direct patient care and difficulties in getting a quick overview of a patient's condition. In order to obtain this information, nurses needed to search through EHRs' many different sections. The results of this review suggest that hospital administrators and policy makers who are interested in adopting the EHR system should understand what benefits to expect from employing EHRs and how best to implement them in order to improve the quality and efficiency of patient care. Moreover, the review results, especially the negative ones, will help future adopters of EHRs anticipate and solve those kinds of problems prior to implementing the system. Ultimately, future researchers, particularly those who conduct quantitative studies, might use the findings of this review to develop their instruments for data 
collection or to help analyze their quantitative data that are related to the EHR system and patient care. In this dissertation, the results of this review were used for developing the background and significance of the dissertation research.

The results of the second manuscript (quantitative review), "The Effects of Using Electronic Health Records on the Quality of Diabetes Care: An Integrative Literature Review," clearly highlight that EHR use enhances the quality of diabetes care (process and intermediate outcomes) in primary care and community-based practices. Specifically, findings show that the reviewed 11 articles used different guidelines to measure quality of diabetes care, but the main components of these guidelines were derived from the same source, the National Diabetes Quality Improvement Alliance (NDQIA). The NDQIA guidelines are also compatible with the EHR meaningful use (MU) core objectives that are used by the CMS to identify health care professionals and hospitals that qualify for the EHR incentive payments. Moreover, this review found that six studies reported significant improvements in diabetes care, particularly $\mathrm{HbA} 1 \mathrm{c}$, eye, foot, BP measurements, and nephropathy screening after EHR implementation. Two studies demonstrate that EHRs can improve both diabetes care and intermediate outcomes (i.e., BP). However, three studies argued that EHR use did not improve the quality of diabetes care. The findings of this review conclude that EHR use tended to enhance quality of diabetes care, mainly in primary care and community-based practices. Nevertheless, as of 2013, 22\% of practices had not adopted an EHR system (Hsiao \& Hing, 2014).

Consequently the results of this review can be used as evidence for hospital administrators to consider the adoption of EHRs. Furthermore, another recommendation of this review is that further research needs to be conducted, particularly a longitudinal 
study with a large sample size (based on the statistical power analysis), utilizing the most accurate measurement for assessing diabetes care quality, and reducing variance by examining the same patients over time. Finally, we suggest that future studies utilize the NDQIA to measure quality of diabetes care because it is accurate and complete and aligns with the Stage 1 and Stage 2 MU core objectives. In this dissertation, the findings of the review were used to develop the background, significance, design, and methods of the dissertation research.

Finally, the results of the dissertation research reveal that quality of diabetes care for 1,201 patients diagnosed with type 2 diabetes who visited the same healthcare system differed before and after EHR implementation. The process of diabetes care, mainly BP reading and BP recording, was reported to have improved significantly one year and two years after EHR implementation. A statistically significant improvement in the proportion of patients achieving total cholesterol level $<170 \mathrm{mg} / \mathrm{dL}$ was also found to have occurred two years after EHR implementation. However, a significant decrease also emerged in high density lipoprotein-cholesterol (HDL-C) levels one year and two years post-EHR. Male patients were associated with lower HDL-C levels one year and two years post-EHR. Two other unexpected results from this study were that patients were less likely to achieve a glycosylated hemoglobin (HbA1c) level $\leq 7 \%$ and systolic blood pressure (SBP) level $<140 \mathrm{mmHg}$ post-EHR. The findings demonstrate that the EHR will not directly lead to better patient outcomes, but it will affect changes in clinician and patient behavior based on better data recorded at the point of care. Further studies examining the effect of other EHR comprehensive components (e.g., clinical decision support system, best practice alerts, and disease management registries) on quality of 
diabetes care are recommended. Suggestions for hospital administrators to consider EHR adoption and to add nursing care elements to their EHRs are also offered by this study. 


\section{References}

Hsiao, C-J., \& Hing, E. (2014). Use and characteristics of electronic health record systems among office-based physician practices: United States, 2001-2013. National Center for Health Statistics Data Brief, 143, 1-7. 


\section{APPENDIX A}

Table 1

Electronic Requirements for Classification of Hospitals as Having a Comprehensive or Basic Electronic Health Record (EHR) System

\begin{tabular}{|c|c|c|}
\hline Requirement & $\begin{array}{l}\text { Comprehensive EHR } \\
\text { System }\end{array}$ & $\begin{array}{l}\text { Basic EHR } \\
\text { System }\end{array}$ \\
\hline \multicolumn{3}{|l|}{ Clinical documentation } \\
\hline Demographic characteristics of patients & $\sqrt{ }$ & $\sqrt{ }$ \\
\hline Physicians' notes & $\sqrt{ }$ & $\sqrt{ }$ \\
\hline Nursing assessments & $\sqrt{ }$ & $\sqrt{ }$ \\
\hline Problem lists & $\sqrt{ }$ & $\sqrt{ }$ \\
\hline Medication lists & $\sqrt{ }$ & $\sqrt{ }$ \\
\hline Discharge summaries & $\sqrt{ }$ & $\sqrt{ }$ \\
\hline Advanced directives & $\sqrt{ }$ & - \\
\hline \multicolumn{3}{|l|}{ Test and imaging results } \\
\hline Laboratory reports & $\sqrt{ }$ & $\sqrt{ }$ \\
\hline Radiologic reports & $\sqrt{ }$ & $\sqrt{ }$ \\
\hline Radiologic images & $\sqrt{ }$ & - \\
\hline Diagnostic-test results & $\sqrt{ }$ & $\sqrt{ }$ \\
\hline Diagnostic-test images & $\sqrt{ }$ & - \\
\hline Consultant reports & $\sqrt{ }$ & - \\
\hline \multicolumn{3}{|l|}{ Computerized provider-order entry } \\
\hline Laboratory tests & $\sqrt{ }$ & - \\
\hline Radiologic tests & $\sqrt{ }$ & - \\
\hline Medications & $\sqrt{ }$ & $\sqrt{ }$ \\
\hline Consultation requests & $\sqrt{ }$ & - \\
\hline Nursing orders & $\sqrt{ }$ & - \\
\hline \multicolumn{3}{|l|}{ Decision support } \\
\hline Clinical guidelines & $\sqrt{ }$ & - \\
\hline Clinical reminders & $\sqrt{ }$ & - \\
\hline Drug-allergy alerts & $\sqrt{ }$ & - \\
\hline Drug-drug interaction alerts & $\sqrt{ }$ & - \\
\hline $\begin{array}{l}\text { Drug-laboratory interaction alerts (e.g., digoxin and low } \\
\text { level of serum potassium) }\end{array}$ & $\begin{array}{l}\sqrt{ } \\
\sqrt{ }\end{array}$ & - \\
\hline Drug-dose support (e.g., renal dose guidance) & & \\
\hline
\end{tabular}

Source: Jha, A. K., DesRoches, C. M., Campbell, E. G., Donelan, K., Rao, S. R., Ferris, T. G., Shields, A. E., Rosenbaum, S., \& Blumenthal, D. (2009). The use of electronic health records in US hospitals. The New England Journal of Medicine, 360(16), 1628-1638. 


\section{APPENDIX B}

Table 4

Quality of Care (Structure, Process, and Intermediate-Outcome) for Patients Diagnosed with Type 2 Diabetes in Three Time Points

\begin{tabular}{|c|c|c|c|c|c|c|c|c|c|c|c|c|c|c|c|c|}
\hline \multirow[b]{2}{*}{ Variable } & \multicolumn{5}{|c|}{ Pre EHR } & \multicolumn{5}{|c|}{ One Year Post EHR } & \multicolumn{5}{|c|}{ Two Years Post EHR } & \multirow[b]{2}{*}{$p$} \\
\hline & $\begin{array}{c}n \\
(\%)\end{array}$ & $\begin{array}{c}M \\
(S D)\end{array}$ & $M d n$ & Mode & $\begin{array}{c}\text { Min. } \\
- \\
\text { Max. }\end{array}$ & $\begin{array}{c}n \\
(\%)\end{array}$ & $\begin{array}{c}M \\
(S D)\end{array}$ & $M d n$ & Mode & $\begin{array}{c}\text { Min. } \\
- \\
\text { Max. }\end{array}$ & $\begin{array}{c}n \\
(\%)\end{array}$ & $\begin{array}{c}M \\
(S D)\end{array}$ & $M d n$ & Mode & $\begin{array}{c}\text { Min. } \\
- \\
\text { Max. }\end{array}$ & \\
\hline Structure & & & & & & & & & & & & & & & & \\
\hline $\begin{array}{l}\text { Patients } \\
\text { diagnosed } \\
\text { with type } 2 \\
\text { diabetes who } \\
\text { visited } \\
\text { outpatient } \\
\text { units in three } \\
\text { time points } \\
\text { and had } \\
\text { intermediate- } \\
\text { outcome } \\
\text { values } \\
\text { documented in } \\
\text { the CDR }\end{array}$ & $\begin{array}{r}1201 \\
(100)\end{array}$ & - & - & - & - & $\begin{array}{r}1201 \\
(100)\end{array}$ & & - & - & - & $\begin{array}{r}1201 \\
(100)\end{array}$ & - & - & - & - & - \\
\hline $\begin{array}{l}\text { Number of } \\
\text { outpatient } \\
\text { visits }\end{array}$ & $\begin{array}{l}5363 \\
(100)\end{array}$ & $\begin{array}{r}4.5 \\
(3.7)\end{array}$ & 3 & 3 & $\begin{array}{l}0- \\
36\end{array}$ & $\begin{array}{l}5421 \\
(100)\end{array}$ & $\begin{array}{r}4.5 \\
(4.3)\end{array}$ & 3 & 2 & $\begin{array}{l}0- \\
38\end{array}$ & $\begin{array}{l}7744 \\
(100)\end{array}$ & $\begin{array}{r}6.4 \\
(5.7)\end{array}$ & 5 & 3 & $\begin{array}{l}0- \\
66\end{array}$ & - \\
\hline $\begin{array}{l}\text { Process } \\
\text { Measures }\end{array}$ & & & & & & & & & & & & & & & & \\
\hline $\begin{array}{l}\mathrm{HbA1c} \\
\text { measurement }\end{array}$ & & & & & & & & & & & & & & & & \\
\hline $\begin{array}{l}\text { Number of } \\
\text { visits with } \\
\text { documented } \\
\text { HbA1c } \\
\text { measurement }\end{array}$ & $\begin{array}{l}2566 \\
(100)\end{array}$ & - & - & - & - & $\begin{array}{r}2593 \\
(100)\end{array}$ & - & - & - & - & $\begin{array}{r}2401 \\
(100)\end{array}$ & 0 & - & - & - & - \\
\hline $\begin{array}{l}\text { Frequency of } \\
\text { HbA1c } \\
\text { measurement }\end{array}$ & $\begin{array}{r}1091 \\
(100)\end{array}$ & $2.4(1)$ & 2 & 2 & $1-8$ & $\begin{array}{r}1094 \\
(100)\end{array}$ & $\begin{array}{r}2.4 \\
(1.1)\end{array}$ & 2 & 2 & $1-8$ & $\begin{array}{r}1052 \\
(100)\end{array}$ & $2.3(1)$ & 2 & 2 & $1-9$ & - \\
\hline $\begin{array}{l}\text { Pre EHR vs. } \\
\text { One Year Post } \\
\text { EHR }\end{array}$ & $\begin{array}{r}1025 \\
(100)\end{array}$ & $2.4(1)$ & - & - & - & $\begin{array}{r}1025 \\
(100)\end{array}$ & $\begin{array}{r}2.4 \\
(1.1)\end{array}$ & - & - & - & - & - & - & - & - & 0.563 \\
\hline
\end{tabular}


Table 4

Quality of Care (Structure, Process, and Intermediate-Outcome) for Patients Diagnosed with Type 2 Diabetes in Three Time Points

\begin{tabular}{|c|c|c|c|c|c|c|c|c|c|c|c|c|c|c|c|c|}
\hline \multirow[b]{2}{*}{ Variable } & \multicolumn{5}{|c|}{ Pre EHR } & \multicolumn{5}{|c|}{ One Year Post EHR } & \multicolumn{5}{|c|}{ Two Years Post EHR } & \multirow[b]{2}{*}{$p$} \\
\hline & $\begin{array}{c}n \\
(\%)\end{array}$ & $\begin{array}{c}M \\
(S D)\end{array}$ & $M d n$ & Mode & $\begin{array}{l}\text { Min. } \\
- \\
\text { Max. }\end{array}$ & $\begin{array}{c}n \\
(\%)\end{array}$ & $\begin{array}{c}M \\
(S D)\end{array}$ & $M d n$ & Mode & $\begin{array}{c}\text { Min. } \\
- \\
\text { Max. }\end{array}$ & $\begin{array}{c}n \\
(\%)\end{array}$ & $\begin{array}{c}M \\
(S D)\end{array}$ & $M d n$ & Mode & $\begin{array}{c}\text { Min. } \\
- \\
\text { Max. }\end{array}$ & \\
\hline $\begin{array}{l}\text { Pre EHR vs. } \\
\text { Two Years } \\
\text { Post EHR }\end{array}$ & $\begin{array}{r}988 \\
(100)\end{array}$ & $2.4(1)$ & - & - & - & - & - & - & - & - & $\begin{array}{r}988 \\
(100)\end{array}$ & $2.3(1)$ & - & - & - & 0.007 \\
\hline \multicolumn{17}{|l|}{ BP measurement } \\
\hline $\begin{array}{l}\text { Number of } \\
\text { visits with } \\
\text { documented } \\
\text { BP } \\
\text { measurement }\end{array}$ & $\begin{array}{l}2631 \\
(100)\end{array}$ & - & - & - & - & $\begin{array}{r}3722 \\
(100)\end{array}$ & - & - & - & - & $\begin{array}{l}5490 \\
(100)\end{array}$ & - & - & - & - & - \\
\hline $\begin{array}{l}\text { Frequency of } \\
\text { BP } \\
\text { measurement }\end{array}$ & $\begin{array}{r}660 \\
(100)\end{array}$ & $4(3.1)$ & 3 & 2 & $\begin{array}{l}1- \\
29\end{array}$ & $\begin{array}{r}899 \\
(100)\end{array}$ & $\begin{array}{r}4.1 \\
(3.6)\end{array}$ & 3 & 1 & $1-40$ & $\begin{array}{l}1128 \\
(100)\end{array}$ & $\begin{array}{r}4.9 \\
(3.7)\end{array}$ & 4 & 3 & $1-41$ & - \\
\hline $\begin{array}{l}\text { Pre EHR vs. } \\
\text { One Year Post } \\
\text { EHR }\end{array}$ & $\begin{array}{r}640 \\
(100)\end{array}$ & $\begin{array}{r}4.1 \\
(3.1)\end{array}$ & - & - & - & $\begin{array}{r}640 \\
(100)\end{array}$ & $\begin{array}{r}4.9 \\
(3.9)\end{array}$ & - & - & - & - & - & - & - & - & 0.000 \\
\hline $\begin{array}{l}\text { Pre EHR vs. } \\
\text { Two Years } \\
\text { Post EHR }\end{array}$ & $\begin{array}{r}652 \\
(100)\end{array}$ & $4(3.1)$ & - & - & - & - & - & - & - & - & $\begin{array}{r}652 \\
(100)\end{array}$ & $5.2(4)$ & - & - & - & 0.000 \\
\hline \multicolumn{17}{|l|}{$\begin{array}{l}\text { Total cholesterol } \\
\text { measurement }\end{array}$} \\
\hline $\begin{array}{l}\text { Number of } \\
\text { visits with } \\
\text { documented } \\
\text { total } \\
\text { cholesterol } \\
\text { measurement } \\
\end{array}$ & $\begin{array}{l}1731 \\
(100)\end{array}$ & - & - & - & - & $\begin{array}{l}1712 \\
(100)\end{array}$ & & - & - & - & $\begin{array}{r}1587 \\
(100)\end{array}$ & - & - & - & - & - \\
\hline $\begin{array}{l}\text { Frequency of } \\
\text { total } \\
\text { cholesterol } \\
\text { measurement }\end{array}$ & $\begin{array}{r}953 \\
(100)\end{array}$ & $1.8(1)$ & 2 & 1 & $\begin{array}{l}1- \\
12\end{array}$ & $\begin{array}{r}980 \\
(100)\end{array}$ & $1.7(1)$ & 1 & 1 & $1-8$ & $\begin{array}{r}966 \\
(100)\end{array}$ & $\begin{array}{r}1.6 \\
(0.9)\end{array}$ & 1 & 1 & $1-7$ & - \\
\hline $\begin{array}{l}\text { Pre EHR vs. } \\
\text { One Year Post } \\
\text { EHR }\end{array}$ & $\begin{array}{r}826 \\
(100)\end{array}$ & $\begin{array}{r}1.9 \\
(1.1)\end{array}$ & - & - & - & $\begin{array}{r}826 \\
(100)\end{array}$ & $\begin{array}{r}1.8 \\
(1.1)\end{array}$ & - & - & - & - & - & - & - & - & 0.076 \\
\hline $\begin{array}{l}\text { Pre EHR vs. } \\
\text { Two Years } \\
\text { Post EHR }\end{array}$ & $\begin{array}{r}818 \\
(100)\end{array}$ & $\begin{array}{r}1.8 \\
(1.1)\end{array}$ & - & - & - & & & - & - & - & $\begin{array}{r}818 \\
(100)\end{array}$ & $\begin{array}{r}1.7 \\
(0.9)\end{array}$ & - & - & - & 0.000 \\
\hline $\begin{array}{l}\text { HDL cholesterol } \\
\text { measurement }\end{array}$ & & & & & & & & & & & & & & & & \\
\hline
\end{tabular}


Table 4

Quality of Care (Structure, Process, and Intermediate-Outcome) for Patients Diagnosed with Type 2 Diabetes in Three Time Points

\begin{tabular}{|c|c|c|c|c|c|c|c|c|c|c|c|c|c|c|c|c|}
\hline \multirow[b]{2}{*}{ Variable } & \multicolumn{5}{|c|}{ Pre EHR } & \multicolumn{5}{|c|}{ One Year Post EHR } & \multicolumn{5}{|c|}{ Two Years Post EHR } & \multirow[b]{2}{*}{$p$} \\
\hline & $\begin{array}{c}n \\
(\%)\end{array}$ & $\begin{array}{c}M \\
(S D)\end{array}$ & $M d n$ & Mode & $\begin{array}{c}\text { Min. } \\
- \\
\text { Max. }\end{array}$ & $\begin{array}{c}n \\
(\%)\end{array}$ & $\begin{array}{c}M \\
(S D)\end{array}$ & $M d n$ & Mode & $\begin{array}{c}\text { Min. } \\
- \\
\text { Max. }\end{array}$ & $\begin{array}{c}n \\
(\%)\end{array}$ & $\begin{array}{c}M \\
(S D)\end{array}$ & $M d n$ & Mode & $\begin{array}{c}\text { Min. } \\
- \\
\text { Max. }\end{array}$ & \\
\hline $\begin{array}{l}\text { Number of } \\
\text { visits with } \\
\text { documented } \\
\text { HDL } \\
\text { cholesterol } \\
\text { measurement }\end{array}$ & $\begin{array}{r}1721 \\
(100)\end{array}$ & - & - & - & - & $\begin{array}{l}1703 \\
(100)\end{array}$ & - & - & - & - & $\begin{array}{l}1585 \\
(100)\end{array}$ & - & - & - & - & - \\
\hline $\begin{array}{l}\text { Frequency of } \\
\text { HDL } \\
\text { cholesterol } \\
\text { measurement }\end{array}$ & $\begin{array}{r}948 \\
(100)\end{array}$ & $1.8(1)$ & 2 & 1 & $\begin{array}{l}1- \\
12\end{array}$ & $\begin{array}{r}974 \\
(100)\end{array}$ & $1.7(1)$ & 1 & 1 & $1-8$ & $\begin{array}{r}966 \\
(100)\end{array}$ & $\begin{array}{r}1.6 \\
(0.9)\end{array}$ & 1 & 1 & $1-7$ & - \\
\hline $\begin{array}{l}\text { Pre EHR vs. } \\
\text { One Year Post } \\
\text { EHR }\end{array}$ & $\begin{array}{r}818 \\
(100)\end{array}$ & $\begin{array}{r}1.9 \\
(1.1)\end{array}$ & - & - & - & $\begin{array}{r}818 \\
(100)\end{array}$ & $1.8(1)$ & - & - & - & - & - & - & - & - & 0.079 \\
\hline $\begin{array}{l}\text { Pre EHR vs. } \\
\text { Two Years } \\
\text { Post EHR }\end{array}$ & $\begin{array}{r}815 \\
(100)\end{array}$ & $\begin{array}{r}1.9 \\
(1.1)\end{array}$ & - & - & - & - & - & - & - & - & $\begin{array}{r}815 \\
(100)\end{array}$ & $\begin{array}{r}1.7 \\
(0.9)\end{array}$ & - & - & - & 0.000 \\
\hline $\begin{array}{l}\text { LDL cholesterol } \\
\text { measurement }\end{array}$ & & & & & & & & & & & & & & & & \\
\hline $\begin{array}{l}\text { Number of } \\
\text { visits with } \\
\text { documented } \\
\text { LDL } \\
\text { cholesterol } \\
\text { measurement }\end{array}$ & $\begin{array}{r}1660 \\
(100)\end{array}$ & - & - & - & - & $\begin{array}{l}1632 \\
(100)\end{array}$ & - & - & - & - & $\begin{array}{r}1515 \\
(100)\end{array}$ & - & - & - & - & - \\
\hline $\begin{array}{l}\text { Frequency of } \\
\text { LDL } \\
\text { cholesterol } \\
\text { measurement }\end{array}$ & $\begin{array}{r}929 \\
(100)\end{array}$ & $1.8(1)$ & 2 & 1 & $\begin{array}{l}1- \\
12\end{array}$ & $\begin{array}{r}950 \\
(100)\end{array}$ & $1.7(1)$ & 1 & 1 & $1-8$ & $\begin{array}{r}943 \\
(100)\end{array}$ & $\begin{array}{r}1.6 \\
(0.8)\end{array}$ & 1 & 1 & $1-7$ & - \\
\hline $\begin{array}{l}\text { Pre EHR vs. } \\
\text { One Year Post } \\
\text { EHR }\end{array}$ & $\begin{array}{r}792 \\
(100)\end{array}$ & $\begin{array}{r}1.9 \\
(1.1)\end{array}$ & - & - & - & $\begin{array}{r}792 \\
(100)\end{array}$ & $1.8(1)$ & - & - & - & - & - & - & - & - & 0.096 \\
\hline $\begin{array}{l}\text { Pre EHR vs. } \\
\text { Two Years } \\
\text { Post EHR } \\
\end{array}$ & $\begin{array}{r}786 \\
(100)\end{array}$ & $\begin{array}{r}1.8 \\
(1.1)\end{array}$ & - & - & - & - & - & - & - & - & $\begin{array}{r}786 \\
(100)\end{array}$ & $\begin{array}{r}1.7 \\
(0.9)\end{array}$ & - & - & - & 0.000 \\
\hline $\begin{array}{l}\text { Triglycerides } \\
\text { measurement }\end{array}$ & & & & & & & & & & & & & & & & \\
\hline $\begin{array}{l}\text { Number of } \\
\text { visits with }\end{array}$ & $\begin{array}{l}1725 \\
(100) \\
\end{array}$ & - & - & - & - & $\begin{array}{r}1700 \\
(100) \\
\end{array}$ & - & - & - & - & $\begin{array}{l}1581 \\
(100) \\
\end{array}$ & - & - & - & - & - \\
\hline
\end{tabular}


Table 4

Quality of Care (Structure, Process, and Intermediate-Outcome) for Patients Diagnosed with Type 2 Diabetes in Three Time Points

\begin{tabular}{|c|c|c|c|c|c|c|c|c|c|c|c|c|c|c|c|c|}
\hline \multirow[b]{2}{*}{ Variable } & \multicolumn{5}{|c|}{ Pre EHR } & \multicolumn{5}{|c|}{ One Year Post EHR } & \multicolumn{5}{|c|}{ Two Years Post EHR } & \multirow[b]{2}{*}{$p$} \\
\hline & $\begin{array}{c}n \\
(\%)\end{array}$ & $\begin{array}{c}M \\
(S D)\end{array}$ & $M d n$ & Mode & $\begin{array}{c}\text { Min. } \\
- \\
\text { Max. }\end{array}$ & $\begin{array}{c}n \\
(\%)\end{array}$ & $\begin{array}{c}M \\
(S D)\end{array}$ & $M d n$ & Mode & $\begin{array}{c}\text { Min. } \\
- \\
\text { Max. }\end{array}$ & $\begin{array}{c}n \\
(\%)\end{array}$ & $\begin{array}{c}M \\
(S D)\end{array}$ & $M d n$ & Mode & $\begin{array}{l}\text { Min. } \\
- \\
\text { Max. }\end{array}$ & \\
\hline $\begin{array}{l}\text { documented } \\
\text { triglycerides } \\
\text { measurement }\end{array}$ & & & & & & & & & & & & & & & & \\
\hline $\begin{array}{l}\text { Frequency of } \\
\text { triglycerides } \\
\text { measurement }\end{array}$ & $\begin{array}{r}948 \\
(100)\end{array}$ & $1.8(1)$ & 2 & 1 & $\begin{array}{l}1- \\
12\end{array}$ & $\begin{array}{r}972 \\
(100)\end{array}$ & $1.7(1)$ & 1 & 1 & $1-8$ & $\begin{array}{r}965 \\
(100)\end{array}$ & $\begin{array}{r}1.6 \\
(0.9)\end{array}$ & 1 & 1 & $1-7$ & - \\
\hline $\begin{array}{l}\text { Pre EHR vs. } \\
\text { One Year Post } \\
\text { EHR }\end{array}$ & $\begin{array}{r}818 \\
(100)\end{array}$ & $\begin{array}{r}1.9 \\
(1.1)\end{array}$ & - & - & - & $\begin{array}{r}818 \\
(100)\end{array}$ & $1.8(1)$ & - & - & - & - & - & - & - & - & 0.075 \\
\hline $\begin{array}{l}\text { Pre EHR vs. } \\
\text { Two Years } \\
\text { Post EHR }\end{array}$ & $\begin{array}{r}815 \\
(100)\end{array}$ & $\begin{array}{r}1.9 \\
(1.1)\end{array}$ & - & - & - & - & - & - & - & - & $\begin{array}{r}815 \\
(100)\end{array}$ & $\begin{array}{r}1.7 \\
(0.9)\end{array}$ & - & - & - & 0.000 \\
\hline \multicolumn{17}{|l|}{$\begin{array}{l}\text { Intermediate- } \\
\text { outcome } \\
\text { Measures }\end{array}$} \\
\hline $\begin{array}{l}\text { The most recent } \\
\text { HbA1c value } \\
(\%)\end{array}$ & $\begin{array}{r}1091 \\
(100)\end{array}$ & $\begin{array}{r}7.5 \\
(1.5)\end{array}$ & - & - & $\begin{array}{l}4.4- \\
15.2\end{array}$ & $\begin{array}{r}1094 \\
(100)\end{array}$ & $\begin{array}{r}7.7 \\
(1.6)\end{array}$ & - & - & $\begin{array}{l}4.6- \\
16.1\end{array}$ & $\begin{array}{c}1052 \\
(100)\end{array}$ & $\begin{array}{r}7.8 \\
(1.6)\end{array}$ & - & - & $\begin{array}{l}4.1- \\
16.1\end{array}$ & \\
\hline $\begin{array}{l}\text { Pre EHR vs. } \\
\text { One Year } \\
\text { Post EHR }\end{array}$ & $\begin{array}{l}1025 \\
(100)\end{array}$ & $\begin{array}{r}7.4 \\
(1.4)\end{array}$ & - & - & - & $\begin{array}{l}1025 \\
(100)\end{array}$ & $\begin{array}{r}7.7 \\
(1.6)\end{array}$ & - & - & - & - & - & - & - & - & 0.000 \\
\hline $\begin{array}{l}\text { Pre EHR vs. } \\
\text { Two Years } \\
\text { Post EHR } \\
\end{array}$ & $\begin{array}{r}988 \\
(100)\end{array}$ & $\begin{array}{r}7.4 \\
(1.5)\end{array}$ & - & - & - & - & - & - & - & - & $\begin{array}{r}988 \\
(100)\end{array}$ & $\begin{array}{r}7.8 \\
(1.6)\end{array}$ & - & - & - & 0.000 \\
\hline \multicolumn{17}{|l|}{$\begin{array}{l}\text { Mean of the last } \\
\text { three BP values } \\
(\mathrm{mmHg})\end{array}$} \\
\hline $\begin{array}{l}\text { Mean of the last } \\
\text { three SBP } \\
\text { values }\end{array}$ & $\begin{array}{r}660 \\
(100)\end{array}$ & $\begin{array}{l}129.3 \\
(14.2)\end{array}$ & - & - & $\begin{array}{r}96- \\
187.3\end{array}$ & $\begin{array}{r}899 \\
(100)\end{array}$ & $\begin{array}{l}131.8 \\
(15.2)\end{array}$ & - & - & $\begin{array}{l}84- \\
210\end{array}$ & $\begin{array}{r}1128 \\
(100)\end{array}$ & $\begin{array}{r}131.1 \\
(14)\end{array}$ & - & - & $\begin{array}{r}89- \\
200.5\end{array}$ & \\
\hline $\begin{array}{l}\text { Pre EHR vs. } \\
\text { One Year } \\
\text { Post EHR } \\
\end{array}$ & $\begin{array}{r}640 \\
(100)\end{array}$ & $\begin{array}{r}129.3 \\
(14.2)\end{array}$ & - & - & - & $\begin{array}{r}640 \\
(100)\end{array}$ & $\begin{array}{c}131.9 \\
(14.5)\end{array}$ & - & - & - & - & - & - & - & - & 0.000 \\
\hline $\begin{array}{l}\text { Pre EHR vs. } \\
\text { Two Years } \\
\text { Post EHR }\end{array}$ & $\begin{array}{r}652 \\
(100)\end{array}$ & $\begin{array}{l}129.3 \\
(14.2)\end{array}$ & - & - & - & & & - & - & - & $\begin{array}{r}652 \\
(100)\end{array}$ & $\begin{array}{r}131.6 \\
(13.6)\end{array}$ & - & - & - & 0.000 \\
\hline
\end{tabular}


Table 4

Quality of Care (Structure, Process, and Intermediate-Outcome) for Patients Diagnosed with Type 2 Diabetes in Three Time Points

\begin{tabular}{|c|c|c|c|c|c|c|c|c|c|c|c|c|c|c|c|c|}
\hline \multirow[b]{2}{*}{ Variable } & \multicolumn{5}{|c|}{ Pre EHR } & \multicolumn{5}{|c|}{ One Year Post EHR } & \multicolumn{5}{|c|}{ Two Years Post EHR } & \multirow[b]{2}{*}{$p$} \\
\hline & $\begin{array}{c}n \\
(\%)\end{array}$ & $\begin{array}{c}M \\
(S D)\end{array}$ & $M d n$ & Mode & $\begin{array}{l}\text { Min. } \\
- \\
\text { Max. }\end{array}$ & $\begin{array}{c}n \\
(\%)\end{array}$ & $\begin{array}{c}M \\
(S D)\end{array}$ & $M d n$ & Mode & $\begin{array}{c}\text { Min. } \\
- \\
\text { Max. }\end{array}$ & $\begin{array}{c}n \\
(\%)\end{array}$ & $\begin{array}{c}M \\
(S D)\end{array}$ & $M d n$ & Mode & $\begin{array}{c}\text { Min. } \\
- \\
\text { Max. }\end{array}$ & \\
\hline $\begin{array}{l}\text { Mean of the last } \\
\text { three DBP } \\
\text { values }\end{array}$ & $\begin{array}{r}660 \\
(100)\end{array}$ & $\begin{array}{r}72.4 \\
(9)\end{array}$ & - & - & $\begin{array}{r}49.3- \\
110\end{array}$ & $\begin{array}{r}899 \\
(100)\end{array}$ & $\begin{array}{l}73.7 \\
(9.2)\end{array}$ & - & - & $\begin{array}{r}48- \\
112.7\end{array}$ & $\begin{array}{c}1128 \\
(100)\end{array}$ & $\begin{array}{c}74.1 \\
(8.6)\end{array}$ & - & - & $\begin{array}{r}46- \\
105.3\end{array}$ & \\
\hline $\begin{array}{l}\text { Pre EHR vs. } \\
\text { One Year } \\
\text { Post EHR } \\
\end{array}$ & $\begin{array}{r}640 \\
(100)\end{array}$ & $\begin{array}{c}72.4 \\
(9.1)\end{array}$ & - & - & - & $\begin{array}{r}640 \\
(100)\end{array}$ & $\begin{array}{r}73.1 \\
(9)\end{array}$ & - & - & - & - & - & - & - & - & 0.036 \\
\hline $\begin{array}{l}\text { Pre EHR vs. } \\
\text { Two Years } \\
\text { Post EHR }\end{array}$ & $\begin{array}{r}652 \\
(100)\end{array}$ & $\begin{array}{r}72.3 \\
(9)\end{array}$ & - & - & - & - & - & - & - & - & $\begin{array}{r}652 \\
(100)\end{array}$ & $\begin{array}{l}73.1 \\
(8.9)\end{array}$ & - & - & - & 0.016 \\
\hline $\begin{array}{l}\text { The most recent } \\
\text { Lipid profile } \\
\text { value (mg/dL) }\end{array}$ & & & & & & & & & & & & & & & & \\
\hline $\begin{array}{l}\text { Total } \\
\text { cholesterol } \\
\text { value }\end{array}$ & $\begin{array}{r}953 \\
(100)\end{array}$ & $\begin{array}{r}164.6 \\
(38)\end{array}$ & - & - & $\begin{array}{r}82- \\
334\end{array}$ & $\begin{array}{r}980 \\
(100)\end{array}$ & $\begin{array}{c}163.4 \\
(40.2)\end{array}$ & - & - & $\begin{array}{r}80- \\
485\end{array}$ & $\begin{array}{r}966 \\
(100)\end{array}$ & $\begin{array}{r}161.7 \\
(40.9)\end{array}$ & - & - & $\begin{array}{c}66- \\
549\end{array}$ & - \\
\hline $\begin{array}{l}\text { Pre EHR vs. } \\
\text { One Year } \\
\text { Post EHR }\end{array}$ & $\begin{array}{r}826 \\
(100)\end{array}$ & $\begin{array}{r}163.6 \\
(37.3)\end{array}$ & - & - & - & $\begin{array}{r}826 \\
(100)\end{array}$ & $\begin{array}{r}162.8 \\
(40.1)\end{array}$ & - & - & - & - & - & - & - & - & 0.550 \\
\hline $\begin{array}{l}\text { Pre EHR vs. } \\
\text { Two Years } \\
\text { Post EHR }\end{array}$ & $\begin{array}{r}818 \\
(100)\end{array}$ & $\begin{array}{c}163.8 \\
(37.9)\end{array}$ & - & - & - & - & - & - & - & - & $\begin{array}{r}818 \\
(100)\end{array}$ & $\begin{array}{c}161.4 \\
(39.5)\end{array}$ & - & - & - & 0.069 \\
\hline $\begin{array}{l}\text { HDL } \\
\text { cholesterol } \\
\text { value }\end{array}$ & $\begin{array}{r}948 \\
(100)\end{array}$ & $\begin{array}{r}42.9 \\
(11.4)\end{array}$ & - & - & $\begin{array}{l}18- \\
104\end{array}$ & $\begin{array}{r}974 \\
(100)\end{array}$ & $\begin{array}{r}42.2 \\
(11.3)\end{array}$ & - & - & $\begin{array}{l}12- \\
107\end{array}$ & $\begin{array}{r}966 \\
(100)\end{array}$ & $\begin{array}{r}42.4 \\
(11.2)\end{array}$ & - & - & $\begin{array}{r}8- \\
111\end{array}$ & - \\
\hline $\begin{array}{l}\text { Pre EHR vs. } \\
\text { One Year } \\
\text { Post EHR } \\
\end{array}$ & $\begin{array}{r}818 \\
(100)\end{array}$ & $\begin{array}{r}42.8 \\
(10.9)\end{array}$ & - & - & - & $\begin{array}{r}818 \\
(100)\end{array}$ & $\begin{array}{r}42.2 \\
(11.4)\end{array}$ & - & - & - & - & - & - & - & - & 0.018 \\
\hline $\begin{array}{l}\text { Pre EHR vs. } \\
\text { Two Years } \\
\text { Post EHR }\end{array}$ & $\begin{array}{r}815 \\
(100)\end{array}$ & $\begin{array}{r}43 \\
(11.1)\end{array}$ & - & - & - & - & - & - & - & - & $\begin{array}{r}815 \\
(100)\end{array}$ & $\begin{array}{r}42.3 \\
(11.3)\end{array}$ & - & - & - & 0.014 \\
\hline $\begin{array}{l}\text { LDL } \\
\text { cholesterol } \\
\text { value }\end{array}$ & $\begin{array}{r}929 \\
(100)\end{array}$ & $\begin{array}{r}94.8 \\
(30.8)\end{array}$ & - & - & $\begin{array}{c}32- \\
229\end{array}$ & $\begin{array}{r}950 \\
(100)\end{array}$ & $\begin{array}{r}93.5 \\
(29.7)\end{array}$ & - & - & $\begin{array}{r}15- \\
236\end{array}$ & $\begin{array}{r}943 \\
(100)\end{array}$ & $\begin{array}{r}91.9 \\
(30.4)\end{array}$ & - & - & $\begin{array}{r}7- \\
296\end{array}$ & - \\
\hline $\begin{array}{l}\text { Pre EHR vs. } \\
\text { One Year } \\
\text { Post EHR }\end{array}$ & $\begin{array}{r}792 \\
(100)\end{array}$ & $\begin{array}{r}94.5 \\
(30.5)\end{array}$ & - & - & - & $\begin{array}{r}792 \\
(100)\end{array}$ & $\begin{array}{r}93.1 \\
(28.9)\end{array}$ & - & - & - & - & - & - & - & - & 0.170 \\
\hline
\end{tabular}


Table 4

Quality of Care (Structure, Process, and Intermediate-Outcome) for Patients Diagnosed with Type 2 Diabetes in Three Time Points

\begin{tabular}{|c|c|c|c|c|c|c|c|c|c|c|c|c|c|c|c|c|}
\hline \multirow[b]{2}{*}{ Variable } & \multicolumn{5}{|c|}{ Pre EHR } & \multicolumn{5}{|c|}{ One Year Post EHR } & \multicolumn{5}{|c|}{ Two Years Post EHR } & \multirow[b]{2}{*}{$p$} \\
\hline & $\begin{array}{c}n \\
(\%)\end{array}$ & $\begin{array}{c}M \\
(S D)\end{array}$ & $M d n$ & Mode & $\begin{array}{l}\text { Min. } \\
- \\
\text { Max. }\end{array}$ & $\begin{array}{c}n \\
(\%)\end{array}$ & $\begin{array}{c}M \\
(S D)\end{array}$ & $M d n$ & Mode & $\begin{array}{l}\text { Min. } \\
- \\
\text { Max. }\end{array}$ & $\begin{array}{c}n \\
(\%)\end{array}$ & $\begin{array}{c}M \\
(S D)\end{array}$ & $M d n$ & Mode & $\begin{array}{l}\text { Min. } \\
- \\
\text { Max. }\end{array}$ & \\
\hline $\begin{array}{l}\text { Pre EHR vs. } \\
\text { Two Years } \\
\text { Post EHR }\end{array}$ & $\begin{array}{r}786 \\
(100)\end{array}$ & $\begin{array}{l}93.7 \\
(30)\end{array}$ & - & - & - & - & - & - & - & - & $\begin{array}{r}786 \\
(100)\end{array}$ & $\begin{array}{r}92.1 \\
(30.4)\end{array}$ & - & - & - & 0.138 \\
\hline $\begin{array}{l}\text { Triglycerides } \\
\text { value }\end{array}$ & $\begin{array}{r}948 \\
(100) \\
\end{array}$ & $\begin{array}{r}162.8 \\
(101.1) \\
\end{array}$ & - & - & $\begin{array}{r}31- \\
959 \\
\end{array}$ & $\begin{array}{r}972 \\
(100) \\
\end{array}$ & $\begin{array}{l}165.5 \\
(146)\end{array}$ & - & & $\begin{array}{r}33- \\
2689\end{array}$ & $\begin{array}{r}965 \\
(100)\end{array}$ & $\begin{array}{r}165.2 \\
(150.9)\end{array}$ & - & - & $\begin{array}{r}32- \\
3203\end{array}$ & - \\
\hline $\begin{array}{l}\text { Pre EHR vs. } \\
\text { One Year } \\
\text { Post EHR }\end{array}$ & $\begin{array}{r}818 \\
(100)\end{array}$ & $\begin{array}{r}159.9 \\
(97.9)\end{array}$ & - & - & - & $\begin{array}{r}818 \\
(100)\end{array}$ & $\begin{array}{r}160.6 \\
(121.6)\end{array}$ & - & - & - & - & - & - & - & - & 0.845 \\
\hline $\begin{array}{l}\text { Pre EHR vs. } \\
\text { Two Years } \\
\text { Post EHR }\end{array}$ & $\begin{array}{r}815 \\
(100)\end{array}$ & $\begin{array}{r}160.7 \\
(100.7)\end{array}$ & - & - & - & - & - & - & - & - & $\begin{array}{r}815 \\
(100)\end{array}$ & $\begin{array}{r}160.3 \\
(112.3)\end{array}$ & - & - & - & 0.910 \\
\hline
\end{tabular}

Note. $p=.05$ from paired-sample $t$-tests. 


\section{APPENDIX C \\ Author Guidelines for International Journal of Nursing Studies}

The International Journal of Nursing Studies provides a forum for publication of scholarly papers that report research findings, research-based reviews, discussion papers and commentaries which are of interest to an international readership of practitioners, educators, administrators and researchers in all areas of nursing, midwifery and the caring sciences.

Papers should address issues of international interest and concern and present the study in the context of the existing international research base on the topic. Those which focus on a single country should identify how the material presented might be relevant to a wider audience and how it contributes to the international knowledge base. Selection of papers for publication is based on their scientific excellence, distinctive contribution to knowledge (including methodological development) and their importance to contemporary nursing, midwifery or related professions.

Submission to this journal proceeds totally online and you will be guided stepwise through the creation and uploading of your files. The system automatically converts your files to a single PDF file, which is used in the peer-review process.

\section{Simplified Submission Service}

As part of the Simplified Submission service, you may choose to submit your manuscript as a single file to be used in the refereeing process. This can be a PDF file or a Word document, in any format or lay-out that can be used by referees to evaluate your manuscript. It should contain high enough quality figures for refereeing. If you prefer to do so, you may still provide all or some of the source files at the initial submission. Please note that individual figure files larger than $10 \mathrm{MB}$ must be uploaded separately please see further guidance below under PREPARATION OF THE MANUSCRIPT. Revised submissions and standard submissions in the house style All authors submitting papers in the journal style, or submitting revised submissions previously submitted via the Simplified route above, will be required to complete Parts 1 and 2 of the Author Checklist during the submission process to assist them in ensuring that the basic requirements of manuscript submission are met, including details of the roles of funding sources and any conflicts of interest. The Author Checklist is designed to be a self-assessment checklist to assist authors in preparing their manuscript and the link is found in the full Author Checklist.

The Guidelines are separated into the following sections:

- Pre-submission considerations

- Types of Paper considered for publication

- Preparation of the Manuscript

- Manuscript Layout

- Documentation required at submission stage

- Post-acceptance

PRE-SUBMISSION CONSIDERATIONS 
Authors should submit to the journal online via the journal's home page or at http://ees.elsevier.com.proxy.its.virginia.edu/ijns. You will be guided through the creation and uploading of the various files, including the Author Checklist. Once the uploading is done, the system automatically generates an electronic (PDF) proof, which is then used for reviewing. All correspondence, including notification of the Editor's decision and requests for revisions, will be by e-mail.

Submitted papers should be relevant to an international audience and authors should not assume knowledge of national practices, policies, law, etc. Authors should consult a recent issue of the journal for style if possible. Since the journal is distributed all over the world, and as English is a second language for many readers, authors are requested to write in plain English and use terminology which is internationally acceptable.

All authors submitting papers in the journal style will be required to complete Parts 1 and 2 of the Author Checklist during the submission process to assist them in ensuring that the basic requirements of manuscript submission are met, including details of the roles of funding sources and any conflicts of interest. The Author Checklist is designed to be a self-assessment checklist to assist authors in preparing their manuscript.

\section{Submission Declaration}

Submission of an article implies that the work described has not been published previously (except in the form of an abstract or as part of a published lecture or academic thesis), that it is not under consideration for publication elsewhere, that its publication is approved by all authors and tacitly or explicitly by the responsible authorities where the work was carried out, and that, if accepted, it will not be published elsewhere in the same form, in English or in any other language, without the written consent of the copyrightholder.

\section{Other/multiple and parallel publications}

The journal seeks to publish original papers that make a substantial novel contribution. Generally the generous word limits of the IJNS permit authors to publish all aspects of a study within a single paper. However we recognize that this is not always possible. Please see our editorial on multiple papers from single studies and duplicate publication http://dx.doi.org.proxy.its.virginia.edu/10.1016/j.ijnurstu.2008.07.003. In order to aid editorial decisions about distinctiveness and to avoid inadvertent duplication please upload copies of all previous, current and under review publications from this study and / or give full detail in the Author Checklist.

All published and in press accounts of the study from which data in this paper must be referred to in the paper and the relationship between this and other publications from the same study must be made clear. It is not sufficient to simply cite a prior publication - the text must state that results are from the same study. Citation of publications 'in press' is acceptable, provided that full detail is given.

If other publications are under review or in preparation this should be mentioned in your letter to the editor and you should give an undertaking that you will take all possible steps to ensure subsequent publications contain a reference to your IJNS publication if you are successful. The study should be referred to by a distinctive name which will be used in any future publications to identify that it as the same study. 


\section{Ethical approval}

All studies must be conducted to a high ethical standard and must adhere to local regulations and standards for gaining scrutiny and approval.

The work described in your article must have been carried out in accordance with The Code of Ethics of the World Medical Association (Declaration of Helsinki) for experiments involving humans http://www.wma.net/en/30publications/10policies/b3/; EC Directive 86/609/EEC for animal experiments http://ec.europa.eu/environment/chemicals/lab_animals/legislation_en.htm. This must be stated at an appropriate point in the article.

For information on Ethics in Publishing and Ethical guidelines for journal publication see http://www.elsevier.com.proxy.its.virginia.edu/authorethics and http://www.elsevier.com.proxy.its.virginia.edu/ethicalguidelines. The approving body and (if relevant) approval number should be identified in the Author Checklist.

\section{Trial or other study registration}

We encourage the prospective registration of studies. Where a study has been registered please give the number in your Author Checklist (e.g. ISRCTN) and include the registration number within the title, abstract or body of the paper as appropriate.

\section{AudioSlides}

The journal encourages authors to create an AudioSlides presentation with their published article. AudioSlides are brief, webinar-style presentations that are shown next to the online article on ScienceDirect. This gives authors the opportunity to summarize their research in their own words and to help readers understand what the paper is about. More information and examples are available at http://www.elsevier.com.proxy.its.virginia.edu/audioslides. Authors of this journal will automatically receive an invitation e-mail to create an AudioSlides presentation after acceptance of their paper.

\section{Role of the funding source}

You are requested to identify who provided financial support for the conduct of the research and/or preparation of the article and to briefly describe the role of the sponsor(s), if any, in study design; in the collection, analysis and interpretation of data; in the writing of the report; and in the decision to submit the paper for publication. If the funding source(s) had no such involvement then this should be stated. Please see http://www.elsevier.com.proxy.its.virginia.edu/funding

\section{Funding Body Agreements and Policies}

Elsevier has established agreements and developed policies to allow authors whose articles appear in journals published by Elsevier, to comply with potential manuscript archiving requirements as specified as conditions of their grant awards. To learn more about existing agreements and policies please visit http://www.elsevier.com.proxy.its.virginia.edu/fundingbodies

\section{Open Access}

This journal offers authors two choices to publish their research;

1. Open Access

- Articles are freely available to both subscribers and the wider public with permitted 
reuse

- An Open Access publication fee is payable by authors or their research funder

2. Subscription

- Articles are made available to subscribers as well as developing countries and patient groups through our access programs

(http://www.elsevier.com.proxy.its.virginia.edu/access)

- No Open Access publication fee

All articles published Open Access will be immediately and permanently free for everyone to read and download. Permitted reuse is defined by your choice of one of the following Creative Commons user licenses:

Creative Commons Attribution-Non Commercial-ShareAlike (CC BY-NC-SA): for noncommercial purposes, lets others distribute and copy the article, to create extracts, abstracts and other revised versions, adaptations or derivative works of or from an article (such as a translation), to include in a collective work (such as an anthology), to text and data mine the article, as long as they credit the author(s), do not represent the author as endorsing their adaptation of the article, do not modify the article in such a way as to damage the author's honor or reputation, and license their new adaptations or creations under identical terms (CC BY NC SA).

Creative Commons Attribution-NonCommercial-NoDerivs (CC-BY-NC-ND): for noncommercial purposes, lets others distribute and copy the article, and to include in a collective work (such as an anthology), as long as they credit the author(s) and provided they do not alter or modify the article.

Creative Commons Attribution (CC-BY): available only for authors funded by organizations with which Elsevier has established an agreement. For a full list please see http://www.elsevier.com.proxy.its.virginia.edu/fundingbodies

Elsevier has established agreements with funding bodies. This ensures authors can comply with funding body Open Access requirements, including specific user licenses, such as CC-BY. Some authors may also be reimbursed for associated publication fees. http://www.elsevier.com.proxy.its.virginia.edu/fundingbodies

To provide Open Access, this journal has a publication fee which needs to be met by the authors or their research funders for each article published Open Access. Your publication choice will have no effect on the peer review process or acceptance of submitted articles. The Open Access publication fee for this journal is 2500 USD, excluding taxes.

Learn more about Elsevier's pricing policy http://www.elsevier.com.proxy.its.virginia.edu/openaccesspricing

\section{Contributors \& Acknowledgements}

All authors should have made substantial contributions to all of the following: (1) the conception and design of the study, or acquisition of data, or analysis and interpretation of data, (2) drafting the article or revising it critically for important intellectual content, (3) final approval of the version to be submitted. In the covering letter to the editorial office, we ask you make a true statement that all authors meet the criteria for authorship, have approved the final article and that all those entitled to authorship are listed as authors. 
Those who meet some but not all of the criteria for authors can be identified as 'contributors' at the end of the manuscript with their contribution specified. All those individuals who provided help during the research (e.g., collecting data, providing language help, writing assistance or proofreading the article, etc.) that do not meet criteria for authorship should be acknowledged in the paper.

Papers with 10 or more authors should give a corporate name for the research group (e.g. ATLAS Research Group) and list all authors and contributors [as defined above] at the end of the paper. Any acknowledgements should be listed additionally, as described above. In the covering letter to the editorial office, we ask that roles for each and every author be individually described, with reference to the criteria for authorship. You must make a true statement that all authors have approved the final article and acknowledge that all those entitled to authorship are listed as authors.

\section{Conflict of interest}

All authors must disclose any financial and personal relationships with other people or organisations that could inappropriately influence (bias) their work. Examples of potential conflicts of interest include employment, consultancies, stock ownership, honoraria, paid expert testimony, patent applications/registrations, and grants or other funding. See also http://www.elsevier.com.proxy.its.virginia.edu/conflictsofinterest.

\section{English Language Service}

Please write your text in good English. Authors who require information about language editing and copyediting services pre- and post-submission please visit http://www.elsevier.com.proxy.its.virginia.edu/languagepolishing or our customer support site at http://epsupport.elsevier.com.proxy.its.virginia.edu for more information. Please note Elsevier neither endorses nor takes responsibility for any products, goods or services offered by outside vendors through our services or in any advertising. For more information please refer to our Terms \& Conditions:

http://www.elsevier.com.proxy.its.virginia.edu/termsandconditions

\section{Review Process}

The decision to publish a paper is based on an editorial assessment and peer review.

Initially all papers are assessed by an editorial committee consisting of 2 or more members of the editorial team. The prime purpose is to decide whether to send a paper for peer review and to give a rapid decision on those that are not.

Editorials and Commentaries may be accepted at this stage but in all other cases the decision is to reject the paper or to send it for peer review. Papers which do not meet basic standards or are unlikely to be published irrespective of a positive peer review, for example because their novel contribution is insufficient or the relevance to the discipline is unclear, may be rejected at this point in order to avoid delays to authors who may wish to seek publication elsewhere. Occasionally a paper will be returned to the author with requests for revisions in order to assist the editors in deciding whether or not send it out for review. Authors can expect a decision from this stage of the review process within 2-3 weeks of submission.

Manuscripts going forward to the review process are reviewed by members of an international expert panel. All such papers will undergo a double blind peer review by two or more reviewers, plus a member of the Associate Editorial Board. All papers are 
subject to peer review and we take every reasonable step to ensure author identity is concealed during the review process. We aim to complete this process within 8 weeks of the decision to review although occasionally delays do happen and authors should allow at least 12 weeks from submissions before contacting the journal. The Editor-in-Chief reserves the right to the final decision regarding acceptance.

\section{Queries}

For questions about the editorial process (including the status of manuscripts under review) please contact the editorial office ijns@kcl.ac.uk . For technical support on submissions please contact http://epsupport.elsevier.com.proxy.its.virginia.edu.

\section{CONSIDERATIONS SPECIFIC TO TYPES OF RESEARCH DESIGNS}

The editors require that manuscripts adhere to recognized reporting guidelines relevant to the research design used. These identify matters that should be addressed in your paper. These are not quality assessment frameworks and your study need not meet all the criteria implied in the reporting guideline to be worthy of publication in the journal. The checklists do identify essential matters that should be considered and reported upon. For example, a controlled trial may or may not be blinded but it is important that the paper identifies whether or not participants, clinicians and outcome assessors were aware of treatment assignments.

You are encouraged (although not required) to submit a checklist from the appropriate reporting guideline together with your paper as a guide to the editors and reviewers of your paper.

Reporting guidelines endorsed by the journal are listed below:

Observational cohort, case control and cross sectional studies - STROBE - Strengthening the Reporting of Observational Studies in Epidemiology http://www.equatornetwork.org/index.aspx?o=1032

Quasi-experimental/non-randomised evaluations - TREND - Transparent Reporting of Evaluations with Non-randomized Designs http://www.equatornetwork.org/index.aspx?o=1032

Randomised (and quasi-randomised) controlled trial - CONSORT - Consolidated Standards of Reporting Trials http://www.equator-network.org/index.aspx?o=1032

Study of Diagnostic accuracy/assessment scale - STARD - Standards for the Reporting of Diagnostic Accuracy Studies http://www.equator-network.org/index.aspx?o=1032

Systematic Review of Controlled Trials - PRISMA - Preferred Reporting Items for Systematic Reviews and Meta-Analyses http://www.equator-

network.org/index.aspx?o=1032

Systematic Review of Observational Studies - MOOSE - Meta-analysis of Observational Studies in Epidemiology http://www.equator-network.org/index.aspx?o=1032

Qualitative researchers might wish to consult the guideline listed below:

Qualitative studies - COREQ - Consolidated criteria for reporting qualitative research. Tong, A., Sainsbury, P., Craig, J., 2007. Consolidated criteria for reporting qualitative research (COREQ): a 32-item checklist for interviews and focus groups. International Journal for Quality in Health Care 19 (6), 349-357. http://intqhc.oxfordjournals.org.proxy.its.virginia.edu/content/19/6/349.full 


\section{TYPES OF PAPERS CONSIDERED FOR PUBLICATION}

The IJNS publishes original research, reviews, study and discussion papers. In addition we publish editorials and commentaries on existing content with the journal. Where a case is made we will also publish protocols of studies.

\section{Editorials - 1,000-2,000 words}

Authors who have ideas for editorials which address issues of substantive concern to the discipline, particularly those of a controversial nature or linked directly to forthcoming content in the journal, should contact the Editor in Chief (ijns@kcl.ac.uk)

\section{Research Papers - 2,000-7,000 words}

Full papers reporting original research can be a maximum of 7000 words in length, although shorter papers are preferred. Research papers should adhere to recognised standards for reporting (see above guidance and Author Checklist).

All research papers reporting the development or testing of scales must include a copy of the full scale as a Supplementary file at submission stage so it can be published as an appendix online; the IJNS does not accept scale development papers which are not accompanied by a copy of the full scale. Authors are required to obtain written permission from the copyright owner of the scale to reproduce it, and ensure that it is credited appropriately and the correct copyright line qualifying the permission to use/translate the scale is supplied underneath the submitted scale. If authors want to retain copyright of their scale they can mark it as reproduced with their permission.

If the scale is in a language other than English, then it must be accompanied by an English translation. If the newly developed scale is a translation of an existing scale then the IJNS requires author(s) to obtain written permission from the copyright owner of the original scale to publish the translated version with full credit given also to the original scale (an English translation is still also required).

\section{Reviews and Discussion Papers - 2,000-7,000 words}

- Reviews, including:

- systematic reviews, which address focussed practice questions;

- literature reviews, which provide a thorough analysis of the literature on a broad topic;

- policy reviews, i.e. reviews of published literature and policy documents which inform nursing practice, the organisation of nursing services, or the education and preparation of nurses and/or midwives.

- Book Review Articles, i.e. papers which provide a critical discussion of an aspect of nursing with reference to two or more recent publications on a similar topic. The Editorin-Chief welcomes proposals for book review articles, and may also commission them.

- Discussion Papers, i.e. scholarly articles of a debating or discursive nature.

\section{Short scale development reports - up to 1,500 words +5 references}

Short reports of up to 1,500 words and 5 references, reporting the development and or psychometric testing of a scale and including a copy of the full scale so it can be published in full. If authors wish to retain copyright - they can do this by simply marking it as copyright to them / their institution and saying it is reproduced with permission.

\section{Comments and commentaries - 500-1,500 words}


Designed to stimulate academic debate and discussion, the Editor invites readers to submit commentaries (up to 1500 words) or short comments (about 500 words) on papers recently published in the IJNS. Contributions that are of general interest, stimulating and meet the standards of scholarship associated with the Journal may be selected for publication in a commentary section or as a standalone contribution. Contributions should be submitted as in the usual way. Abstracts, Keywords, Classifications and the Author Checklist are not required for Comments and Commentaries.

\section{PREPARATION OF THE MANUSCRIPT} NEW SUBMISSIONS:

Submission to this journal proceeds totally online and you will be guided stepwise through the creation and uploading of your files. The system automatically converts your files to a single PDF file, which is used in the peer-review process.

As part of the Simplified Submission service, you may choose to submit your manuscript as a single file to be used in the refereeing process. This can be a PDF file or a Word document, in any format or lay-out that can be used by referees to evaluate your manuscript. It should contain high enough quality figures for refereeing. If you prefer to do so, you may still provide all or some of the source files at the initial submission. Please note that individual figure files larger than $10 \mathrm{MB}$ must be uploaded separately. The manuscript must be blinded for the peer review process and a separate title page (with author details and affiliations must be uploaded as a separate file).

\section{References:}

There are no strict requirements on reference formatting. References can be in any style or format as long as the style is consistent. Author(s) name(s), journal title / book title, article title, year of publication, volume and issue / book chapter and the pagination must be present. The reference style required by the journal will be applied to the published version by Elsevier.

\section{Formatting requirements:}

There are no strict formatting requirements but all manuscripts must contain the essential elements needed to convey your manuscript, for example Abstract, Keywords, Introduction, Materials and Methods, Results, Conclusions, Artwork and Tables with Captions.

If your article includes any Videos and/or other Supplementary material, this should be included in your initial submission for peer review purposes.

Divide the article into clearly defined sections. It is not necessary to format your manuscript in double column layout, even if the journal has a double column layout.

Abstract - Abstracts should be less than 350 words, and should not include references or abbreviations.

Abstracts of research papers must be structured and should adopt the headings suggested by the relevant reporting guidelines (see below). In general they should include the following Background; Objectives; Design; Settings (do not specify actual centres, but give the number and types of centre and geographical location if important); Participants (details of how selected, inclusion and exclusion criteria, numbers entering and leaving the study, relevant clinical and demographic characteristics); Methods; Results, report main outcome(s) / findings including (where relevant) levels of statistical significance 
and confidence intervals; and Conclusions, which should relate to study aims and hypotheses.

Abstracts for reviews should provide a summary under the following headings, where possible: Objectives, Design, Data sources, Review methods, Results, Conclusions.

Abstracts for book review articles and discussion papers should provide a concise summary of the line of argument pursued and conclusions.

Key Words - Provide between four and ten key words in alphabetical order, which accurately identify the paper's subject, purpose, method and focus. Use the Medical Subject Headings (MeSH®) thesaurus or Cumulative Index to Nursing and Allied Health (CINAHL) headings where possible (see http://www.nlm.nih.gov.proxy.its.virginia.edu/mesh/meshhome.html ).

Abbreviations - Avoid the use of abbreviations unless they are likely to be widely recognised. In particular you should avoid abbreviating key concepts in your paper where readers might not already be familiar with the abbreviation. Any abbreviations which the authors intend to use should be written out in full and followed by the letters in brackets the first time they appear, thereafter only the letters without brackets should be used.

Statistics - Standard methods of presenting statistical material should be used. Where methods used are not widely recognised explanation and full reference to widely accessible sources must be given.

Exact $\mathrm{p}$ values should be given to no more than three decimal places.

Wherever possible give both point estimates and confidence intervals for all population parameters estimated by the study (e.g. group differences, frequency of characteristics)

Identify the statistical package used (please note that SPSS has not been "Statistical Package for the Social Sciences" for many years).

Informed consent - Where applicable authors should confirm that informed consent was obtained from human subjects and that ethical clearance was obtained from the appropriate authority.

Permissions - Permission to reproduce previously published material must be obtained in writing from the copyright holder (usually the publisher) and acknowledged in the manuscript.

Word limits - Our experience suggests that all things being equal, readers find shorter papers more useful than longer ones. Given this, and competition for space in the Journal, shorter papers of between 2,000 and 3,500 words are preferred. However, full papers may be up to 7,000 words in length, plus tables, figures, and references. Ordinarily there should be no appendices although in the case of papers reporting tool development or the use of novel questionnaires it is usual to include a copy of the tool as an appendix.

"Contribution of the Paper"

Statements of:

- What is already known about the topic?

- What this paper adds?

Required for all papers (with the exception of Commentaries) is a clear summary of 'What is already known about the topic?' and 'What this paper adds' identifying existing 
research knowledge relating to the specific research question / topic and a summary of the new knowledge added by this study

Under each of these headings, please provide clear OUTCOME statements in the form of two or three bullet points for each. Do NOT give process statements of what the paper does.

eg. This review demonstrates that nurse-led intermediate care reduces hospital stay but increases total inpatient stay (outcome) NOT This review considers the impact of nurseled intermediate care on acute stay and total inpatient stay (process).

In addition you will be prompted during the online submission process to confirm Ethical Approval has been obtained where appropriate, and to provide "Contribution of the Paper" as is the case for all new submissions. For "Simpler Submissions" you are not required to complete and return the Author Checklist but you may find reference to this in the submission process helpful.

STANDARD AND REVISED SUBMISSIONS IN THE HOUSE JOURNAL STYLE

(please refer to the Author Checklist for further guidance on preparing your manuscript).

\section{MANUSCRIPT LAYOUT}

Title - The title should be in the format 'Topic / question: design/type of paper' and identify the population / care setting studied.(e.g. The effectiveness of telephone support for adolescents with insulin dependent diabetes: controlled before and after study).

\section{"Contribution of the Paper" \\ Statements of: \\ -What is already known about the topic? \\ - What this paper adds?}

Required for all papers (with the exception of Commentaries) is a clear summary of 'What is already known about the topic?' and 'What this paper adds' identifying existing research knowledge relating to the specific research question / topic and a summary of the new knowledge added by this study

Under each of these headings, please provide clear OUTCOME statements in the form of two or three bullet points for each. Do NOT give process statements of what the paper does.

eg. This review demonstrates that nurse-led intermediate care reduces hospital stay but increases total inpatient stay (outcome) NOT This review considers the impact of nurseled intermediate care on acute stay and total inpatient stay (process).

References - The reference style required by the journal will be applied to the published version by Elsevier but if you wish to format references yourself they should be arranged in a name/date citation style and should be consistent throughout. Avoid citation of personal communications or unpublished material. Citations to material in press (i.e accepted for publication) is acceptable. Citation of material currently under consideration elsewhere (e.g. "under review" or "submitted") is not.

All publications cited in the text should be presented in a list of references following the text of the manuscript. In the text refer to the author's name (without initials) and year of publication (e.g. "Since Peterson (1993) has shown that?" or "This finding is supported by results obtained later (Kramer, 1994)"). For three or more authors use the first author 
followed by "et al.", in the text. For one or more references in the text to support a single idea, the names should be organized alphabetically (Bryman, 2004, Lincoln and Guba, 2000, Onwuegbuzie and Leech, 2005). No more than three references should be used to support a single idea.

\section{Reference management software}

This journal has a standard template available in the reference management package EndNote (http://www.endnote.com/support/enstyles.asp). Using plug-ins to wordprocessing packages, authors only need to select the appropriate journal template when preparing their article and the list of references and citations to these will be formatted according to the journal style which is the Harvard reference style.

The list of references should be arranged alphabetically by authors' names. References should be arranged first alphabetically and then further sorted chronologically if necessary. More than one reference from the same author(s) in the same year must be identified by the letters "a", "b", "c", etc., placed after the year of publication.

References should be given in the following form:

Arthur, D., Sohng, K.Y., Noh, C.H., Kim, S., 1998. The professional self concept of Korean hospital nurses. International Journal of Nursing Studies 35 (3), 155-162.

Barnes, B., Bloor, D., 1982. Relativism, rationalism and the sociology of knowledge. In: Hollis, M., Lukes, S. (Eds.), Rationality and Relativism. Basil Blackwell, Oxford, pp. 2147.

Dijkstra, A., Buist, G., Dassen, Th.W.N., 1996. Nursing-care dependency: development and psychometric testing of the NCD-scale for demented and mentally handicapped inpatients. In: Proceedings of the 8th Biennial Conference of the WENR, Research on Nursing throughout the Lifespan, vol. 1. Ekblad and Co, Vastervik, pp. 117-126.

Gower, B., 1997. Scientific method: an historical and philosophical introduction. Routledge, London.

Web references - As a minimum, the page name, full URL and date of access should be given. Any further information, if known (author names, dates, etc.), should also be given. Where there is no named author, authorship may be attributed to the organisation producing the site, (if appropriate) Where journal articles have been accessed online a full bibliographic reference to the publication should be given in the style illustrated above although a doi or web address may be added.

Royal College of Nursing (2012) New RCN initiative to shape nursing's future. http://www.rcn.org.uk/newsevents/news/article/uk/new_rcn_initiative_to_shape_nursings future accessed 5/12/2012

\section{REVISED SUBMISSIONS}

Regardless of the file format of the original submission, at revision you must provide us with an editable file of the entire article. Keep the layout of the text as simple as possible. Most formatting codes will be removed and replaced on processing the article. The electronic text should be prepared in a way very similar to that of conventional manuscripts (see also the Guide to Publishing with Elsevier: http://www.elsevier.com.proxy.its.virginia.edu/guidepublication). See also the section on Electronic artwork. 
To avoid unnecessary errors you are strongly advised to use the 'spell-check' and 'grammar-check' functions of your word processor.

\section{DOCUMENTATION REQUIRED FOR HOUSE JOURNAL STYLE AND REVISED SUBMISSION STAGE}

Manuscripts must be electronic files. You will need to prepare the following files for submission:

Covering letter - to the editor in which you detail authorship contributions and other matters you wish the editors to consider.

Title page - Include full name, job title, highest academic and professional qualification and institution for each author. Indicate an e-mail address for the corresponding author. Include acknowledgements to key contributors.

Author Checklist - Parts 1 and 2.

Manuscript - The manuscript with a font size of 12 or $10 \mathrm{pt}$ double-spaced with wide margins $(2.5 \mathrm{~cm}$ at least) and numbered pages. Depending on the paper type this should include the title, abstract, key words, "what the paper adds", text, references, tables, figure legends, figures, appendix.

Table and figures - There should be no more than five tables and figures in total and included in a separate file. All tables and figures should be clearly labelled. If your manuscript includes more than 5 tables in total, or for very large tables, these can be submitted as Supplementary Data and will be included as such in the online version of your article.

File formats - General points

- Make sure you use uniform lettering and sizing of your original artwork.

- Save text in illustrations as "graphics" or enclose the font.

- Only use the following fonts in your illustrations: Arial, Courier, Times, Symbol.

- Number the illustrations according to their sequence in the text.

- Use a logical naming convention for your artwork files.

- Provide captions to illustrations separately.

- Produce images near to the desired size of the printed version.

- Submit each figure as a separate file.

A detailed guide on electronic artwork is available on our website: http://www.elsevier.com.proxy.its.virginia.edu/artworkinstructions

\section{Formats}

Regardless of the application used, when your electronic artwork is finalised, please "save as" or convert the images to one of the following formats (note the resolution requirements for line drawings, halftones, and line/halftone combinations given below):

- EPS: Vector drawings. Embed the font or save the text as "graphics".

- TIFF: color or grayscale photographs (halftones): always use a minimum of $300 \mathrm{dpi}$.

- TIFF: Bitmapped line drawings: use a minimum of $1000 \mathrm{dpi}$.

- TIFF: Combinations bitmapped line/half-tone (color or grayscale): a minimum of 500 dpi is required.

- DOC, XLS or PPT: If your electronic artwork is created in any of these Microsoft

Office applications please supply "as is". 
Please do not:

- Supply embedded graphics in your wordprocessor (spreadsheet, presentation) document.

- Supply files that are optimised for screen use (like GIF, BMP, PICT, WPG); the resolution is too low.

- Supply files that are too low in resolution.

- Submit graphics that are disproportionately large for the content.

Appendices - Ordinarily there should be no appendices although in the case of papers reporting tool development or the use of novel questionnaires authors must include a copy of the tool as an appendix unless all items appear in a table in the text.

\section{POST ACCEPTANCE}

\section{Changes to authorship}

This policy concerns the addition, deletion, or rearrangement of author names in the authorship of accepted manuscripts:

Before the accepted manuscript is published in an online issue: Requests to add or remove an author, or to rearrange the author names, must be sent to the Journal Manager from the corresponding author of the accepted manuscript and must include: (a) the reason the name should be added or removed, or the author names rearranged and (b) written confirmation (e-mail, fax, letter) from all authors that they agree with the addition, removal or rearrangement. In the case of addition or removal of authors, this includes confirmation from the author being added or removed. Requests that are not sent by the corresponding author will be forwarded by the Journal Manager to the corresponding author, who must follow the procedure as described above. Note that: (1) Journal Managers will inform the Journal Editors of any such requests and (2) publication of the accepted manuscript in an online issue is suspended until authorship has been agreed.

After the accepted manuscript is published in an online issue: Any requests to add, delete, or rearrange author names in an article published in an online issue will follow the same policies as noted above and result in a corrigendum.

\section{Proofs}

One set of page proofs (as PDF files) will be sent by e-mail to the corresponding author (if we do not have an e-mail address then paper proofs will be sent by post) or, a link will be provided in the e-mail so that authors can download the files themselves. Elsevier now provides authors with PDF proofs which can be annotated; for this you will need to download Adobe Reader version 7 (or higher) available free from http://www.adobe.com/products/acrobat/readstep2.html . Instructions on how to annotate PDF files will accompany the proofs (also given online). The exact system requirements are given at the Adobe site: http://www.adobe.com/products/acrobat/acrrsystemreqs.html\#70win .

If you do not wish to use the PDF annotations function, you may list the corrections (including replies to the Query Form) and return them to Elsevier in an e-mail. Please list your corrections quoting line number. If, for any reason, this is not possible, then mark the corrections and any other comments (including replies to the Query Form) on a printout of your proof and return by fax, or scan the pages and e-mail, or by post. Please 
use this proof only for checking the typesetting, editing, completeness and correctness of the text, tables and figures. Significant changes to the article as accepted for publication will only be considered at this stage with permission from the Editor. We will do everything possible to get your article published quickly and accurately. Therefore, it is important to ensure that all of your corrections are sent back to us in one communication: please check carefully before replying, as inclusion of any subsequent corrections cannot be guaranteed. Proofreading is solely your responsibility. Note that Elsevier may proceed with the publication of your article if no response is received.

\section{Offprints}

The corresponding author, at no cost, will be provided with a PDF file of the article via email. The PDF file is a watermarked version of the published article and includes a cover sheet with the journal cover image and a disclaimer outlining the terms and conditions of use. Additional paper offprints can be ordered by the authors. An order form with prices will be sent to the corresponding author.

\section{Copyright}

Upon acceptance of an article, authors will be asked to complete a 'Journal Publishing Agreement' (for more information on this and copyright see http://www.elsevier.com.proxy.its.virginia.edu/copyright ). Acceptance of the agreement will ensure the widest possible dissemination of information. An e-mail will be sent to the corresponding author confirming receipt of the manuscript together with a 'Journal Publishing Agreement' form or a link to the online version of this agreement.

Subscribers may reproduce tables of contents or prepare lists of articles including abstracts for internal circulation within their institutions. Permission of the Publisher is required for resale or distribution outside the institution and for all other derivative works, including compilations and translations (please consult http://www.elsevier.com.proxy.its.virginia.edu/permissions). If excerpts from other copyrighted works are included, the author(s) must obtain written permission from the copyright owners and credit the source(s) in the article. Elsevier has preprinted forms for use by authors in these cases: please consult http://www.elsevier.com.proxy.its.virginia.edu/permissions .

The IJNS is a signatory journal to the Uniform Requirements for Manuscripts

Submitted to Biomedical Journals, issued by the International Committee for Medical Journal Editors (ICMJE), and to the Committee on Publication Ethics (COPE) code of conduct for editors. Our guidelines should be read in conjunction with this broader guidance. The ICJME requirements can be found at http://www.icmje.org and the COPE's guidelines at http://publicationethics.org/files/u2/New_Code.pdf.

The IJNS would like to make authors aware that on occasions it may participate in independent third party academic (non-commercial) research which supports the development of high quality scholarly publishing. In some cases, authors may also be invited to participate. Participation will always be voluntary and will not impact on any future editorial decisions on the manuscript. 


\section{APPENDIX D \\ Author Guidelines for Computers, Informatics, Nursing}

\section{Instructions for Authors}

Purposes of the Journal: $C I N$ is designed as a forum for communication among nurses who use computers. As a refereed journal, $C I N$ is a vehicle for the publication of highquality, relevant, and timely articles on a variety of topics related to the use of computers in, and application of computer technology to, contemporary nursing practice, education, research, and administration. Articles in CIN are selected to reflect the diversity of computer hardware, software, and applications which nurses use in their work to provide current and useful information to a broad audience of readers. CIN Plus is an added feature of the journal 12 times a year. CIN Plus is devoted to in-depth practical information on everyday computing issues, and other topics such as informatics education and career development.

About the Journal: $C I N$ began in 1983 as a newsletter. Founding editor Gary D. Hales guided the journal from this modest beginning to the journal it is today. In January 1995, Leslie H. Nicoll was appointed Editor-in-Chief. CIN is now published online monthly by Lippincott Williams \& Wilkins of Philadelphia, PA, a division of Wolters-Kluwer Health, and indexed in CINAHL, the International Nursing Index, MEDLINE, and Social Science Citation Index.

Ethical and Legal Considerations: A submitted manuscript must be an original contribution not previously published (except as an abstract or a preliminary report), must not be under consideration for publication elsewhere, and, if accepted, must not be published elsewhere in similar form, in any language, without the consent of Lippincott Williams \& Wilkins. Each person listed as an author is expected to have participated in the work to a significant extent. Although the editors and reviewers make every effort to ensure the validity of published manuscripts, the final responsibility rests with the authors, not with the Journal, its editors, or the publisher.

Conflicts of Interest: Authors must state all possible conflicts of interest in the manuscript, including financial, consultant, institutional and other relationships that might lead to bias or a conflict of interest. If there is no conflict of interest, this should also be explicitly stated as none declared. All sources of funding should be acknowledged in the manuscript. All relevant conflicts of interest and sources of funding should be included on the title page of the manuscript with the heading "Conflicts of Interest and Source of Funding." For example:

Conflicts of Interest and Source of Funding: A has received honoraria from Company Z. B is currently receiving a grant (\#12345) from Organization Y, and is on the speaker's bureau for Organization $\mathrm{X}$ - the CME organizers for Company A. For the remaining authors none were declared.

Copyright Transfer: Each author must complete and submit the journal's copyright transfer agreement, updated 2011, which includes a section on the disclosure of potential 
conflicts of interest based on the recommendations of the International Committee of Medical Journal Editors, "Uniform Requirements for Manuscripts Submitted to Biomedical Journals" (www.icmje.org/update.html). The form is available on CIN Editorial Manager home page (http://cin.edmgr.com) and can be completed with digital signatures and submitted electronically. For additional information about electronically signing this form, please visit http://links.lww.com/ZUAT/A106.

Please note that as of June 2009 manuscripts will not be sent on to peer review until the signed forms have been received. Blank forms uploaded with manuscripts will be returned to authors for signature.

\section{Compliance with NIH and Other Research Funding Agency Accessibility}

Requirements: A number of research funding agencies now require or request authors to submit the post-print (the article after peer review and acceptance but not the final published article) to a repository that is accessible online by all without charge. As a service to our authors, LWW will identify to the National Library of Medicine (NLM) articles that require deposit and will transmit the post-print of an article based on research funded in whole or in part by the National Institutes of Health, Wellcome Trust, Howard Hughes Medical Institute, or other funding agencies to PubMed Central. The revised Copyright Transfer Agreement allows authors to indicate these funding sources, and it is important that this document be uploaded in electronic form so that the article is forwarded for posting to the appropriate venues. In addition, funding sources should be listed on the title page of the manuscript for proper acknowledgment in the event the article is published.

Permissions: If previously copyrighted materials are used in original form, or adapted for use, in an article submitted to $C I N$, the authors must submit written permission from the copyright owner (usually either the publisher or author of the original) allowing use of the material in the $C I N$ article. Complete details about the source (for example, if it is a journal article, book chapter, survey instrument, or diagram of a model) should be included on the page with the reprinted material in the same format as the reference list. The phrase "Reprinted with permission" should follow the reference.

Any permissions fees required by the copyright owner are the responsibility of the authors requesting use of the borrowed material, not the responsibility of Lippincott Williams \& Wilkins.

There are two links to permissions requests available through the Files and Resources menu associated with the Information for Authors link at the Web site. The first, LWW Publications Reprint Permission, is for LWW publications. The second, Permissions Requests for Non-LWW Publications, can be filled out as needed and faxed, mailed, or emailed to copyright holders other than LWW.

You may also use a letter of permission that you obtain independently. If it is a paper form, scan the signed permission and save as a PDF file, then attach the file as a submission item. If it is an e-mail, copy and paste the text into a Word document and upload as a file. Please select "copyright transfer form" as the item type so that it will 


\section{not be incorporated into the review copy.}

Authors must obtain written permission to adapt or reproduce the following material. Detailed information on requirements for permissions and the terms for "Fair Use" of published works is available in American Medical Association Manual of Style (10th ed., chapter 5).

- Research instruments (such as surveys)

- Unpublished communications (oral or written)

- Any table, figure, or illustration that is reproduced exactly or adapted to fit the needs of the subject

- Models on which an article is based

- Digital works such as photographs, slides, radiographs, scans, chromatographs, and audio and video files

Quotations from books or articles must not cover more than a few consecutive paragraphs, or more than $10 \%$ of the source material. All quoted text must be cited with a reference and specific page numbers where the quoted text appears in the source, according to AMA Style.

Original works developed by the authors of an article submitted to CIN (such as photographs, artwork, models, or instruments) that have been previously copyrighted and are used in the article may qualify for an "amended to exclude" copyright transfer form. Please contact the editorial office for further information.

For Translation Rights \& Licensing queries, contact Silvia Serra, Translation Rights, Licensing \& Permissions Manager, Wotlers Kluwer Health (Medical Research) Ltd, 250 Waterloo Road, London SE1 8RD, UK. PHone: +44 (0) 207981 0600. E-mail:

silvia.serra@wolterskluwer.com. For Special Projects and Reprints (US/Canada), contact Alan Moore, Director of Sales, Lippincott Williams \& Wilkins, Two Commerce Square, 2001 Market Street, Philadelphia, PA 19103. Phone: 215-521-8638. E-mail: alan.moore@wolterskluwer.com. For Special Projects and Reprints (non-US/Canada), contact Silvia Serra, Translation Rights, Licensing \& Permissions Manager, Wotlers Kluwer Health (Medical Research) Ltd, 250 Waterloo Road, London SE1 8RD, UK. PHone: +44 (0) 207981 0600. E-mail: silvia.serra@wolterskluwer.com.

Anonymous Review: Manuscripts are reviewed anonymously by peer reviewers with expertise in the manuscript topic area. Authors should not identify themselves or their institutions other than on the title page. The title page will not be seen by reviewers, and reviewers' identities will not be revealed to authors.

Manuscript Preparation: Manuscripts must be formatted according to the following instructions or they will be returned for corrections before undergoing peer review.

Abstract: The Abstract should appear in two places: (1) typed or copied and pasted into the designated window on the Web page during the submission process; and (2) in 
the body of the manuscript on a separate page just after the title page. Abstracts will be sent to reviewers with the invitation to review. Limit the abstract to 200 words. Do not cite references or define abbreviations or acronyms (for example, "personal digital assistant (PDA)") in the abstract. The abstract should briefly summarize the major issue, problem, or topic being addressed, and the findings and/or conclusions of the manuscript. Please do not submit a structured abstract; CIN employs a narrative abstract form. Structured abstracts can be converted to narrative form by removing subheadings and allowing text to flow in a single paragraph.

Key words: Like the abstract, key words should be provided twice: (1) typed or copied and pasted into a designated box on the Web page during the submission process; and (2) in the body of the manuscript on the same page as the abstract. Provide three to five key words, separated by semicolons, to describe the contents of the manuscript. Terms that appear in Cumulative Index to Nursing \& Allied Health Literature (CINAHL) or The National Library of Medicine's Medical Subject Headings (MeSH) are the most helpful. The key words are used in indexing your manuscript when it is published.

Title page: The title page will be submitted as a separate file when you are instructed to attach files to your submission. This allows Editorial Manager to generate a reviewer copy that contains no author identification. Compose your title page using your word processor, then attach this file when you reach the "attach files" step in the submission process. Include on the title page (a) complete manuscript title; (b) authors' full names, highest academic degrees, and affiliations; (c) name and address for correspondence, including fax number, telephone number, and e-mail address; and (d) any acknowledgements, credits or disclaimers.

Please note that CIN will not publish degree candidacies such as PhD(c). Only the highest awarded degree will be included in author credentials on published manuscripts.

Disclosure: All sources of funding and possible conflicts of interest must be disclosed on the title page, including consultant, institutional, and other relationships that might lead to bias or a conflict of interest. If there is no conflict of interest, this should also be explicitly stated as none declared.

Please list this information with the heading "Conflicts of Interest and Source of Funding." For example:

Conflicts of Interest and Source of Funding: A has received honoraria from Company Z. B is currently receiving a grant (\#12345) from Organization Y, and is on the speaker's bureau for Organization $\mathrm{X}$ - the CME organizers for Company A. For the remaining authors none were declared.

Please be sure to note funding from any of the following organizations: National Institutes of Health (NIH); Wellcome Trust; Howard Hughes Medical Institute (HHMI); and other(s) who may require open public access to the article after publication.

Manuscript: The manuscript will be submitted as a separate file when you are instructed to attach files to your submission. Compose your manuscript using your 
word processor, then attach this file when you reach the "attach files" step in the submission process.

Please note the following guidelines for preparing your manuscript:

- Prepare the manuscript double spaced in Microsoft Word. Leave a 1-inch margin on all sides. Allow a ragged right margin for text --- not justified.

- Type all headings on a separate line. Do not number headings.

- Number all manuscript pages consecutively in the upper right-hand corner (text and references, followed by illustrations on separate pages).

- All legends for Tables and Figures are to be included at the end of manuscript after the list of references. Tables and Figures are attached as separate files when you reach "attach files" in the submission process. Further instructions for preparing figures are given below.

- Although CIN does not specify a font or point size, in general a 12-point serif or 11-point sans serif font will result in the preferred manuscript length.

- Manuscript length (not including references, tables, and figures) should be no more than 15-18 pages (standard $8.5 \times 11$ inch page size). As a general rule, an 18-page paper should have no more than 4 figures or tables.

- Please refer to the American Medical Association Manual of Style, 10th edition, copyright 2007, for citations and references. See examples for citations and references below.

- No identifying information (authors' names) should be included on the manuscript. However, if you cite your own works, please list them just as you would any other reference.

Text: Nonresearch papers should begin with a brief introduction followed by the body of the paper. Use headings and subheadings as appropriate to divide the text.

Research papers should be provided in standard format. Research reports must include information about the institutional review process and adherence to guidelines for the ethical conduct of research. For qualitative research reports, do not prepare a table listing participants and their demographic characteristics line by line. It is a threat to anonymity, and will not be published. Describe participants as group data. For similar reasons, do not "tag" each quotation by participant, thereby linking the quotations throughout the article to a particular participant.

In both cases use the American Medical Association (AMA) Manual of Style, 10th edition, for reference formatting.

Abbreviations and acronyms: Write out the full term for each abbreviation or acronym at its first use unless it is a standard unit of measure. Include the acronym in parentheses after the full term; thereafter, please use the acronym consistently. 
References: The authors are responsible for the accuracy of the references. Key the references (double-spaced) at the end of the manuscript. Limit the number of references to 50 .

In accordance with AMA Style, cite the references in text in the order of appearance. Cite unpublished data - such as papers submitted but not yet accepted for publication and personal communications, including e-mail communications - in parentheses in the text. Personal communications may require written permission; please specify whether the communication is oral or written.

Citation generators available online may be helpful if you are unfamiliar with AMA style or if the references are already in another style such as APA. Papers submitted in APA style will be returned to the author for reformatting before peer reviewers are invited.

For equipment and software used in the process of research, list the manufacturer's name and location (city and state or city and country if not in the US) after the first mention of the software or device in the text of the article.

Do Not cite equipment or software as a reference. Do Not include manufacturer information in the reference list.

\section{Example:}

PowerPoint (Microsoft, Redmond, WA) was used to prepare slides for the presentation.

The citations and reference list are to be styled according to the American Medical Association Manual of Style, 10th edition, copyright 2007. Examples of citations within the text and reference list style are as follows:

\section{Examples:}

Citation: Reliability has been established previously, ${ }^{1,2-8,19}$

Citation following a quote: Jacobsen concluded that "the consequences of muscle strength..." $5(\mathrm{pp} 3,4)$

\section{Reference list: Books}

1. Lewinsohn P. Depression in adolescents. In: Gottlib IH, Hammen CL, eds. Handbook of Depression. New York, NY: Guilford Press; 2002:541-553.

2. Brender, J. Handbook of Evaluation Methods for Health Informatics. Massachusetts: Elsevier Academic Press; 2006.

\section{Reference list: Journal articles (with abbreviated journal names)}

3. Im EO, Chee W, Tsai HM, Lim HJ, Guevara E, Liu Y. Evaluation criteria for internet cancer support groups. Comput Inform Nurs. 2010 May-Jun;28(3):183-8.

\section{Reference list: unpublished material}

4. Sieger M. The nature and limits of clinical medicine. In: Cassell EJ, Siegler M., eds. Changing Values in Medicine. Chicago: University of Chicago Press. In press. 
Reference list: dissertation and thesis

5. Fenster SD. Cloning and Characterization of Piccolo, a Novel Component of the Presynaptic Cytoskeletal Matrix [dissertation]. Birmingham: University of Alabama; 2000.

\section{Reference list: World Wide Web}

6. Cohen, EP (2009). Nephrotic syndrome. Available at http://emedicine.medscape.com/article/244631-overview. Accessed February 22, 2010.

\section{Reference list: Journal using DOI numbers}

8. Kitajima TS, Kawashima SA, Watanabe Y. The conserved kinetochore protein shugoshin protects centromeric cohesion during meiosis. Nature. 2004;427(6974):510517. Doi:10.1039/nature02312.

\section{Reference list: Online Journal with parallel print presence}

9. Duchin JS. Can preparedness for biological terrorism save us from pertussis? Arch Pediatr Adolesc Med. 2004:158(2):106-107. http://archpedi.amaassn.org/cgi/content/full/158/2/106. Accessed June 1, 2004.

\section{Reference list: Online-only Journal (no page numbers, no DOI)}

10. e-Health Ethics Initiative. E-Health Code of Ethics. J Med Internet Res. 2000;2(2):e9. http://www.jmir.org/2000/2/e9. Published May 24, 2000. Accessed April 29, 2004.

Reference formatting is covered fully in Chapter 3 of the AMA Manual of Style, $10^{\text {th }}$ edition.

\section{Figures:}

\section{A) Creating Digital Artwork}

- Learn about the publication requirements for Digital Artwork: http://links.lww.com/ES/A42

- Create, Scan and Save your artwork and compare your final figure to the Digital Artwork Guideline Checklist (below).

- Upload each figure to Editorial Manager in conjunction with your manuscript text and tables.

\section{B) Digital Artwork Guideline Checklist}

Here are the basics to have in place before submitting your digital artwork:

- Artwork should be saved as TIFF, EPS, or MS Office (DOC, PPT, XLS) files. High resolution PDF files are also acceptable.

- Crop out any white or black space surrounding the image. 
- Diagrams, drawings, graphs, and other line art must be vector or saved at a resolution of at least $1200 \mathrm{dpi}$. If created in an MS Office program, send the native (DOC, PPT, XLS) file.

- Photographs, radiographs and other halftone images must be saved at a resolution of at least $300 \mathrm{dpi}$.

- Photographs and radiographs with text must be saved as postscript or at a resolution of at least $600 \mathrm{dpi}$.

- Each figure must be saved and submitted as a separate file. Figures should not be embedded in the manuscript text file.

\section{Remember:}

- Cite figures consecutively in your manuscript.

- Number figures in the figure legend in the order in which they are discussed.

- Upload figures consecutively to the Editorial Manager web site and enter figure numbers consecutively in the Description field when uploading the files.

Tables: Create tables using the table creation and editing feature of your word processing software; do not use Excel or comparable spreadsheet programs. Cite tables consecutively in the text, and number them in that order. Each table should appear on a separate page and should include the table title, appropriate column heads, and explanatory legends (including definitions of any abbreviations used). Do not embed tables within the body of the manuscript. They should be self-explanatory and should supplement, rather than duplicate, the material in the text.

\section{Supplemental Digital Content}

Authors may submit certain types of Supplemental Digital Content (SDC) via Editorial Manager to $C I N$ to be considered for online posting. SDC is subject to editorial approval and, if approved, will be included with the manuscript when it undergoes peer review. Materials may include text documents, graphs, audio, or video files that meet formatting requirements. For a list of all available file types and detailed instructions, please visit http://links.lww.com/A142.

On the Attach Files page of the submission process, please select Supplemental Audio, Video, or Data as appropriate before uploading the file as the Submission Item. If an article with SDC is accepted, production staff will create a live URL in the article linking to the SDC file. The URL will be placed in a call-out within the article. SDC files are not copy-edited by LWW staff and will be presented digitally as submitted and approved by editorial staff.

\section{SDC Call-outs}

Supplemental Digital Content must be cited consecutively in the text of the submitted manuscript. Citations should include the type of material submitted (Audio, Figure, 
Table, etc.), be clearly labeled as "Supplemental Digital Content," include the sequential list number, and provide a description of the supplemental content. All descriptive text should be included in the call-out as it will not appear elsewhere in the article.

Example:

We performed many tests on the degrees of flexibility in the elbow (see Video, Supplemental Digital Content 1, which demonstrates elbow flexibility) and found our results inconclusive.

\section{List of Supplemental Digital Content}

A listing of Supplemental Digital Content must be submitted at the end of the manuscript file. Include the SDC number and file type of the Supplemental Digital Content. This text will be used by production staff and removed from the article before publication.

\section{Example:}

Supplemental Digital Content 1. wmv

\section{SDC File Requirements}

All acceptable file types are permissible up to $10 \mathrm{MBs}$. For audio or video files greater than $10 \mathrm{MBs}$, authors should first query the journal office for approval. For a list of all available file types and detailed instructions, please visit http://links.lww.com/A142.

\section{Online Manuscript Submission}

All manuscripts must be submitted on-line through the CIN Editorial Manager Web site at: http://cin.edmgr.com.

First-time users: Click the "Register" button from the main menu (on the upper banner) and enter the requested information. On successful registration, you will be sent an e-mail indicating your user name and password. Save a copy of this information for future reference. Then log into the system as an author.

Return users: If you have received an e-mail from us with an assigned user ID and password as an author or as a reviewer, do not register again. Simply log in as an author. If you have forgotten your password, click on the "Forgot Your Password?" link, fill in the fields with your name and e-mail address, and click "submit." Your password will be e-mailed to the address you provide regardless of the information in your contact record. Once you have an assigned ID and password, you do not have to re-register, even if your status changes (that is, author, reviewer, or editor). CIN user IDs and passwords are not shared; if you are registered at another journal's EM site, you must register again for CIN.

After you log in as an author, you can submit your manuscript according to the step-bystep instructions on the Web page. You will receive an e-mail confirmation after the manuscript is submitted; the e-mail will contain instructions on how to track the progress of your manuscript through the system. If you experience any problems, please refer to the detailed "Author Tutorial" guide available on the Editorial Manager Web site. If you 
still need assistance, contact the Editorial Office by e-mail at edit@medesk.com.

$C I N$ editorial staff does everything in its power to ensure timely peer review and editorial decision cycles. Manuscript status is posted at the Web site and updates when the following milestones are reached:

- After successful submission, status is "submitted to journal." If the status is "incomplete," then you may need to return to the site to review and approve the final PDF, or a required item was omitted from the submission.

- After the manuscript undergoes technical review and is assigned to an editor, status is "With Editor."

- When reviewers are invited, status changes to "Reviewer invited."

- When reviewers accept invitations, status changes to "under review." In some cases, if a reviewer is unable to complete an assignment, status may change back to "reviewer invited" as subsequent invitations are issued.

- When reviews are complete, status changes to "Required reviews complete."

- If a revised manuscript is submitted to the journal for an editorial decision, the status may remain "with editor" for a period of time as the article is queued for an editorial review.

Editorial Manager menus are role- and context-sensitive and will serve up the current manuscript status immediately when you log in to the site. If you have questions about status terms, or if a period in the review cycle seems to take longer than expected, please contact the editorial office.

Please be aware that multiple status queries may slow the review and editorial cycles as staff take the time to research and answer questions individually.

\section{After Acceptance}

As of 2011, CIN has made the transition to article-based publishing. Manuscripts will be published in electronic format as they are accepted, rather than waiting for an issue assignment. This "publish ahead of print" (PAP) model provides more timely publication and indexing for articles accepted by the journal.

Page proofs and corrections: Corresponding authors will receive electronic page proofs to check the copyedited and typeset article before publication. An e-mail containing a link to a portable document format (PDF) file of the typeset pages and support documents (eg, reprint order form) will be sent to the corresponding author by production staff. The PDF is generated so that authors can make comments directly on the electronic version with no need to print pages and fax corrections back to the production editor.

It is the author's responsibility to ensure that there are no errors in the proofs. Changes that have been made to conform to journal style will stand if they do not alter the authors' meaning. Only the most critical changes to the accuracy of the content will be made. 
Changes that are stylistic or are a reworking of previously accepted material will be disallowed. The publisher reserves the right to deny any changes that do not affect the accuracy of the content.

The corrected proofs will be posted to the journal's PAP Web site and are considered "published ahead of print" at this point. The author will receive a DOI number that will be used to index the article before it is assigned to a volume and issue, and can also be used to reference the article when it assumes final form.

When the online issue to which the article has been assigned is posted at the journal's Web site, the pre-print version of the article will be withdrawn from the journal PAP site.

Complimentary copies: After publication of an article in an issue of CIN, the corresponding author will receive a PDF copy of the typeset article as an e-mail attachment. The PDF is provided as a courtesy, for personal use, and may not be copied or distributed (other than to coauthors on the article) for any purpose, without direct permission from the publisher. 


\title{
APPENDIX E
}

\section{Author Guidelines for Journal of Nursing Care Quality}

\author{
Journal of Nursing Care Quality Online Submission and Review System
}

\section{Editorial Purpose}

The primary objective of the Journal of Nursing Care Quality (JNCQ) is to provide practicing nurses and nurses in leadership roles with useful information about patient safety, quality care, and the application of quality principles in the clinical setting. Articles in the $J N C Q$ address patient safety, innovative and effective approaches to improving quality and safety in healthcare, research on quality care, and evidence-based practice in nursing. The $J N C Q$ provides a forum for the discussion of patient safety issues and "real world" implementation of quality-related activities.

\section{Manuscript Review}

The $J N C Q$ is a peer-reviewed journal. Published manuscripts have been reviewed, selected, and developed with the guidance of the editorial board. Manuscript content is assessed for relevance, accuracy, and usefulness to practicing nurses, nurses in leadership roles, and other healthcare providers involved in evaluating and improving safety and quality of care. Manuscripts are reviewed with the understanding that neither the manuscript nor its essential content has been published or is under consideration by others.

\section{Authorship Responsibility}

All persons designated as authors should qualify for authorship. Each author should have contributed significantly to the conception and design of the work and writing the manuscript to take public responsibility for it. The editor may request justification of assignment of authorship. Names of those who contributed general support or technical help may be listed in an acknowledgment placed after the narrative and before the references.

\section{Query Letters}

Although not necessary, query letters allow the editor to indicate interest in, and developmental advice on, manuscript topics.

\section{Manuscript Preparation}

Prepare manuscripts according to the American Medical Association (AMA) Manual of Style (10th ed) $10^{\text {th }}$ edition. The maximum manuscript length is approximately 18 pages including tables, figures, and references. As a general rule, an 18-page paper should have no more than 3 figures or tables.

For manuscripts describing quality improvement studies, follow the Standards for Quality Improvement Reporting Excellence (SQUIRE) guidelines at http://www.squirestatement.org/guidelines. (see also Oermann MH. SQUIRE guidelines for reporting improvement studies in healthcare: Implications for nursing publications. J Nurs Care Qual.2009; 24(2):91-95 For some manuscripts, it may not be appropriate to include every 
guideline item, but authors should consider each item in preparing their papers for submission. The "Discussion" section should include nursing implications.

\title{
Format
}

Double space the manuscript using a 12-point type size, any font style.

Add page numbers in the upper right-hand corner of each page.

Left justify all text, including headings.

Divide the text into main sections by inserting subheadings.

All headings are flush left, in bold, and distinguished by level as follows:

FIRST-LEVEL HEADING (CAPITALIZED ON SEPARATE LINE)

Second-level heading (Regular on separate line)

Third-level heading (Italic on separate line)

Do not use running headers or footers.

\section{Title/Author Biography Page}

Information for the title/author biography page is placed in a 1-page Word file. This information should not be placed in any other file. This title page Word file should contain only the:

Title of the manuscript;

1. Author(s) names and credentials (highest earned credential only, followed by RN, and certifications);

2. Author(s) affiliation(s): job title, department, institution, city, state, country;

3. Corresponding author: For publication, it is preferable to use a work address. You must include an e-mail address at the end of your mailing address; and

4. Funding information and other disclaimer or disclosure information. Include disclosure of funding received for this work from any of the following organizations: National Institutes of Health (NIH); Wellcome Trust; Howard Hughes Medical Institute (HHMI); and other(s).

\begin{abstract}
Include an abstract of 50 to 75 words that stimulates readers' interest in the topic and states what they will learn from reading the article.
\end{abstract}

\section{Tables and Figures}

Tables and figures, if any, should be saved as individual files. All tables must be numbered consecutively with Arabic numbers and have a title. All figures must be numbered consecutively with Arabic numbers and have a title. Tables and figures must be cited in numerical order in the text. All figures and other artwork should be submitted in black and white.

\section{A) Creating Digital Artwork}

1. Learn about the publication requirements for Digital Artwork: http://links.lww.com/ES/A42

2. Create, Scan and Save your artwork and compare your final figure to the Digital Artwork Guideline Checklist (below).

3. Upload each figure to Editorial Manager in conjunction with your manuscript text and tables. 


\section{B) Digital Artwork Guideline Checklist}

Here are the basics to have in place before submitting your digital artwork:

- Artwork should be saved as TIFF, EPS, or MS Office (DOC, PPT, XLS) files. High resolution PDF files are also acceptable.

- Crop out any white or black space surrounding the image.

- Diagrams, drawings, graphs, and other line art must be vector or saved at a resolution of at least $1200 \mathrm{dpi}$. If created in an MS Office program, send the native (DOC, PPT, XLS) file.

- Photographs, radiographs and other halftone images must be saved at a resolution of at least $300 \mathrm{dpi}$.

- Photographs and radiographs with text must be saved as postscript or at a resolution of at least $600 \mathrm{dpi}$.

- Each figure must be saved and submitted as a separate file. Figures should not be embedded in the manuscript text file.

\section{Remember:}

- Cite figures consecutively in your manuscript.

- Number figures in the figure legend in the order in which they are discussed.

- Upload figures consecutively to the Editorial Manager web site and enter figure numbers consecutively in the Description field when uploading the files.

\section{References}

Prepare references according to the style used in the AMA Manual of Style (10th ed.). References should be typed double-spaced and placed at the end of the manuscript. They should be numbered consecutively in the order in which they are cited in the text. Whenever a reference is repeated in the text, it uses the same reference number each time. Journal titles should be abbreviated according to the listing in the PubMed Journals database. If not listed there, journal titles should be spelled out.

Examples:

Journal article with 1 author:

Clancy CM. The promise and future of comparative effectiveness research. J Nurs Care Qual. 2010;25(1):1-4.

Journal article with multiple authors:

Levin RF, Keefer JM, Marren J, Vetter MJ, Lauder B, Sobolewski S. Evidence-based practice improvement: merging 2 paradigms. J Nurs Care Qual.2010;25(2):117-126.

Book:

Oermann MH, Hays JC. Writing for Publication in Nursing. 2nd ed. New York: Springer;2011.

Web site:

2010 National Patient Safety Goals (NPSGs). The Joint Commission Web site. http://www.jointcommission.org/patientsafety/nationalpatientsafetygoals/. Published June 2006. Accessed May 1, 2010.

For other electronic references, follow guidelines in the AMA Manual of Style p. 63. 


\section{Permissions}

Written permission must be obtained from (1) the holder of copyrighted material used in the manuscript, (2) persons mentioned in the text or acknowledgment, and (3) the administrators of institutions mentioned in the text or acknowledgment. Where permission has been granted, the author should follow any special wording stipulated by the grantor. Letters of permission must be submitted before publication of the manuscript. Permission forms are available under Files and Resources.

\section{Compliance with NIH and Other Research Funding Agency Accessibility Requirements}

A number of research funding agencies now require or request authors to submit the postprint (the article after peer review and acceptance but not the final published article) to a repository that is accessible online by all without charge. As a service to our authors, LWW will identify to the National Library of Medicine articles that require deposit and will transmit the postprint of an article based on research funded in whole or in part by the National Institutes of Health, Wellcome Trust, Howard Hughes Medical Institute, or other funding agencies to PubMed Central. The revised Copyright Transfer Agreement provides the mechanism.

\section{Conflicts of Interest}

Authors must state all possible conflicts of interest in the manuscript, including financial, consultant, institutional and other relationships that might lead to bias or a conflict of interest. If there is no conflict of interest, this should also be explicitly stated as none declared. All sources of funding should be acknowledged in the manuscript. All relevant conflicts of interest and sources of funding should be included on the title page of the manuscript with the heading "Conflicts of Interest and Source of Funding:". For example:

Conflicts of Interest and Source of Funding: A has received honoraria from Company Z. $\mathrm{B}$ is currently receiving a grant (\#12345) from Organization Y, and is on the speaker's bureau for Organization $\mathrm{X}$ - the CME organizers for Company A. For the remaining authors none were declared.

In addition, each author must complete and submit the journal's copyright transfer agreement, which includes a section on the disclosure of potential conflicts of interest based on the recommendations of the International Committee of Medical Journal Editors, "Uniform Requirements for Manuscripts Submitted to Biomedical Journals" (www.icmje.org/update.html). The form is readily available on the manuscript submission page http://www.editorialmanager.com/jncq/ and can be completed and submitted electronically. Please note that authors may sign the copyright transfer agreement form electronically. For additional information about electronically signing this form, go to http://links.lww.com/ZUAT/A106.

\section{Online Manuscript Submission}

All manuscripts must be submitted online through our Web-based Editorial Manager system at

http://jncq.edmgr.com. Submit your manuscript according to the author instructions. You will be able to track the progress of your manuscript through the system.

First-time users: Click the Register button from the menu (on the upper banner) and enter the requested information. On successful registration, you will be sent an e-mail 
indicating your user name and password. Save a copy of this information for future reference.

Return users: If you have received an e-mail from us with an assigned user ID and a password, or if you are a repeat user, do not register again. Just log in. Once you have an assigned ID and a password, you do not have to re-register even if your status changes (ie, author or reviewer).

After registering as an author, log on to http://jncq.edmgr.com and select "Submit a New Manuscript." You will then:

1. Select an "article type" from the drop down menu

2. Enter the title of your manuscript

3. Add information about the author(s) of the paper

4. Enter abstract of your manuscript

5. Enter a few key words that describe your manuscript's content

6. Enter your comments to the editor in a dialogue box, mentioning any prior query you may have had with the editor

7. Attach your various individual files containing elements of your entire manuscript. No file should contain information found in any other file:

Title/author biography page

Abstract

Manuscript text, ending with the references

As many individual files as necessary, each containing 1 table or figure.

When all files are attached, the system will prompt you to complete a process that will submit your manuscript to the editorial office. You will receive an e-mail to let you know that the journal office received your manuscript. After the review process, you will receive an e-mail letting you know the final disposition of the manuscript. You may check the status of your manuscript at any time by logging in to http://jncq.edmgr.com. Select "Submissions Being Processed."

\section{Revised Submission}

If your manuscript is accepted for publication, the revision is submitted online at http://jncq.edmgr.com. Do NOT submit your revision as a "New Submission" under the heading "New Submissions." Log in using the same user name and password. On the Author Main Menu, under the heading "Revisions," select the "Submissions Needing Revision" link, which will be the only active link.

\section{Help}

If at any time during this process you have questions, please e-mail moermann@msn.com or marilyn.oermann@ duke.edu, phone 248-568-1848. The Editorial Office mailing address is Journal of Nursing Care Quality, Marilyn H. Oermann (Editor), 148 Saxapahaw Run, Chapel Hill, North Carolina 27516, USA. 